\title{
DEL ESTADO ABSOLUTO AL ESTADO NEOLIBERAL
}

JAIME CÁRDENAS GRACIA 
DEL ESTADO ABSOLUTO AL ESTADO NEOLIBERAL 


\section{INSTITUTO DE INVESTIGAGIONES JURÍDICAS}

Serie DOGTRINA JuRÍDICA, núm. 793

\section{COORDINACIÓN EDITORIAL}

Lic. Raúl Márquez Romero

Secretario Técnico

Lic. Wendy Vanesa Rocha Cacho

Jefa del Departamento de Publicaciones

José Antonio Bautista Sánchez

Formación en computadora

Mauricio Ortega Garduño

Elaboración de portada 


\section{JAIME CÁRDENAS GRACIA}

\section{DEL ESTADO \\ ABSOLUTO AL ESTADO NEOLIBERAL}
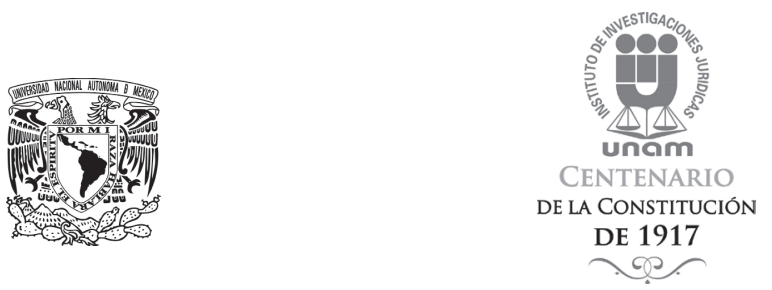

UNIVERSIDAD NACIONAL AUTÓNOMA DE MÉXICO INSTITUTO DE INVESTIGACIONES JURÍDICAS MÉXICO, 2017 
Esta obra fue entregada y editada en 2016, en el marco de las actividades del Proyecto Consejo Nacional de Ciencia y Tecnología (Conacyt), 253286, Cien Años de la Constitución Política de los Estados Unidos Mexicanos (1917-2017). Esta iniciativa, realizada por el Instituto de Investigaciones Jurídicas, con la coordinación de Luis René Guerrero Galván, fue apoyada por ese Consejo con motivo del Centenario de la Constitución Política de los Estados Unidos Mexicanos de 1917. La obra será dada a conocer en 2017, en el aniversario cien de la Constitución.
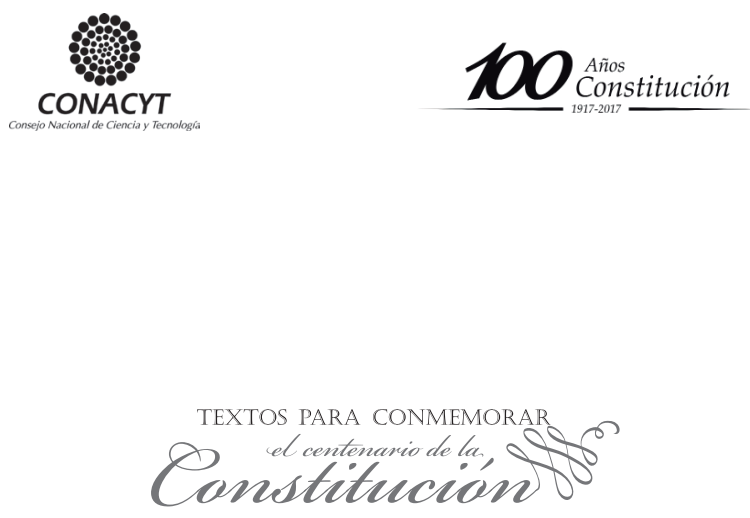

Luis René GUERRERO GALVÁN
Coordinador general

Primera edición: 21 de marzo de 2017

DR @ 2017. Universidad Nacional Autónoma de México

\section{INSTITUTO DE INVESTIGACIONES JURÍDICAS}

Circuito Maestro Mario de la Cueva s/n Ciudad de la Investigación en Humanidades

Ciudad Universitaria, 04510 Ciudad de México

Impreso y hecho en México

ISBN 978-607-02-9058-9 
A María de la Luz, compañera de mi vida 


\section{CONTENIDO}

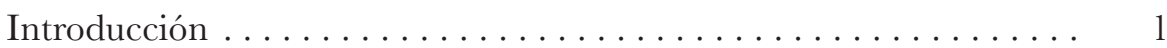

GAPÍTULO PRIMERO

ORÍGENES Y TRANSFORMAGIONES DEL ESTADO MODERNO . . 9

I. Realidad y métodos del Estado moderno. . . . . . . . . . . 9

II. El nacimiento del Estado moderno . . . . . . . . . . . . . . . 15

III. Las teorías del Estado moderno de carácter absoluto . . . . . . . 21

IV. La transformación del Estado absoluto hacia el Estado liberal . . . 31

Gapítulo Segundo

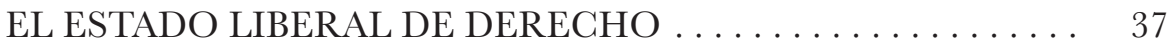

I. Los fundamentos económicos del Estado liberal de derecho. . . . 37

II. Las ideas que propiciaron el Estado liberal de derecho . . . . . . . 40

III. Las revoluciones que consolidaron el Estado liberal de derecho . . 44

IV. El modelo jurídico del Estado liberal de derecho. . . . . . . . 47

V. Las críticas al Estado liberal de derecho ............... 55

VI. El fin del Estado liberal de derecho . . . . . . . . . . . 63

GAPÍTULO TERCERO

EL ESTADO DEL BIENESTAR . . . . . . . . . . . 67

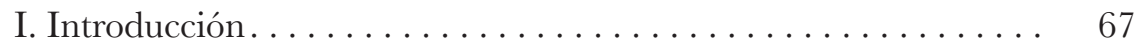

II. Los inicios del Estado social . . . . . . . . . . . . . . . . . . 69

III. El Estado social en el periodo de entreguerras y durante las conflagraciones mundiales. Hacia la construcción del Estado del bie-

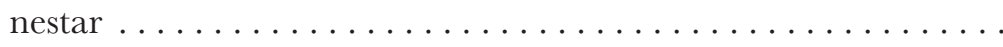


IV. El Estado del bienestar después de $1945 \ldots \ldots \ldots \ldots \ldots \ldots \ldots \quad 78$

V. La crisis del Estado del bienestar . . . . . . . . . . . . . . . 82

VI. El modelo jurídico del Estado del bienestar. . . . . . . . . . . 92

GAPÍTULO CUARTO

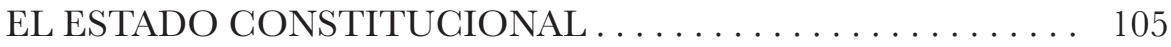

I. ¿Qué es el Estado constitucional? . . . . . . . . . . . . . . 105

II. Los fundamentos filosóficos del Estado constitucional. . . . . . . . 109

III. El modelo jurídico del Estado constitucional. . . . . . . . . . . . 121

IV. Las críticas al Estado constitucional. . . . . . . . . . . . . . . . 124

CAPÍTULO QUINTO

EL ESTADO NEOLIBERAL. . . . . . . . . . . . . . . . . . . . 167

I. La globalización neoliberal respaldada por concepciones geopolíticas ............................. 167

II. La globalización neoliberal . . . . . . . . . . . . . . . . 174

III. La significación económica e ideológica del neoliberalismo . . . . 179

IV. El modelo jurídico de la globalización neoliberal . . . . . . . . . 183

V. Las características neoliberales del Estado, con referencia a Mé-

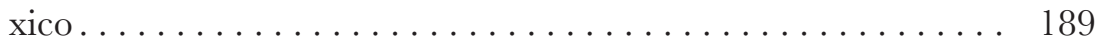

Conclusiones............................... 219

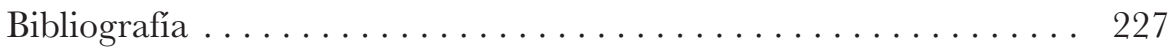


Este libro forma parte del acervo de la Biblioteca Jurídica Virtual del Instituto de Investigaciones Jurídicas de la UNAM

\section{INTRODUGGIÓN}

En el libro que ponemos a disposición del lector se propone, desde una visión jurídica, una breve evolución del Estado moderno durante los últimos quinientos años. Lo que hoy en día llamamos Estado, se distingue de otras formas de organización política previas. Con antelación al Renacimiento existieron estructuras de organización política basadas en la unidad territorial, en la existencia de ejércitos permanentes y/o en la existencia de una hacienda pública. Sin embargo, a diferencia de esas formas pre-estatales en donde podía existir una o algunas de esas características, el Estado moderno reúne todas las anteriores condiciones, e incorpora otras, como la existencia de un orden jurídico exclusivo y uniforme aplicable a un gran territorio, categorías jurídico-políticas como la soberanía, y el monopolio de la fuerza legítima.

Las formas pre-estatales y el Estado moderno tienen en común ser instrumentos de dominación política, pero su diferencia específica radica en el modo de producción económica dominante. Podemos decir que el Estado moderno es la forma de dominación política del modo de producción capitalista. Los teóricos debaten sobre las características definitorias de ese modo de dominación, el sine qua non del capitalismo. Para algunos de ellos, sus elementos cruciales son la mano de obra asalariada, o la producción para el intercambio de ganancias, o la lucha de clases entre empresarios y trabajadores, o el mercado libre. Para otros, lo definitorio del capitalismo es la búsqueda interminable, sin fin y persistente, de la acumulación del capital. ${ }^{1}$

En el libro hacemos un recorrido por los fundamentos económicos, filosóficos y jurídicos del Estado moderno. Establecemos las principales periodizaciones históricas de su manifestación: el Estado absoluto, el Estado liberal de derecho, el Estado del bienestar, el Estado constitucional y el vigente denominado Estado neoliberal. En cada una de esas etapas que corresponden a formas específicas del Estado, elaboramos el modelo jurídico que ha pertenecido a esa estructura de dominación. Estimamos que los modelos jurídicos de las distintas formas del Estado moderno son expresión de sus es-

1 Walerstein, Immanuel, "La crisis estructural, o por qué los capitalistas ya no encuentran gratificante al capitalismo", en Walerstein, Immanuel et al., ¿Tiene futuro el capitalismo.?, México, Siglo XXI Editores, 2015, pp. 15-46. 
Este libro forma parte del acervo de la Biblioteca Jurídica Virtual del Instituto de Investigaciones Jurídicas de la UNAM

tructuras económicas y filosóficas, y que la causa del tránsito de una forma de Estado a otra, obedece fundamentalmente a los cambios que se han ido produciendo al interior del capitalismo durante los últimos quinientos años.

En la forma vigente del Estado, la neoliberal, que se ha definido por el papel que dentro de él juega la economía global capitalista, las razones de preocupación para la garantía de los derechos humanos y de los principios democráticos se han incrementado. Esta forma de Estado asiste al abismo social que se produce al interior de cada país y a nivel mundial, en donde el $1 \%$ de los más ricos tienen el $43 \%$ de la riqueza mundial, mientras que la casi totalidad de la humanidad tiene menos del $2 \%$.

Esta información se confirma, al menos de manera aproximada, con el estudio de Thomas Piketty, que en su famosa obra documenta, a partir del análisis de doscientos años de estadística occidental, cómo el capitalismo global ha producido un sistema en donde la tasa de ganancias del capital excede como nunca antes lo había hecho a la tasa de crecimiento de los salarios y del producto interno bruto (PIB), tanto de las naciones como de los principales países del mundo. El dato más interesante de su obra es que entre 1977 y 2007, el 1\% más rico de los Estados Unidos se ha apropiado del $60 \%$ del crecimiento de la renta nacional de ese país. ${ }^{2}$

Para Piketty, los empresarios de la economía globalizada aumentan su riqueza a tal velocidad que terminan volviéndose rentistas y oligarcas, y cita como ejemplo a Bill Gates, que con 50 billones de dólares sigue volviéndose más rico desde que dejó de trabajar. Lo mismo ocurre con los ejecutivos de las corporaciones trasnacionales, debido a los súper-salarios que se asignan y a las pensiones con que se retiran. Esta forma de capitalismo del siglo XXI, además de crear la más grande desigualdad social histórica tiende a convertirse en un capitalismo patrimonial de rentistas y oligarcas.

Para enfrentar la creciente desigualdad social y los nocivos del capitalismo patrimonial, Piketty propone - de manera insuficiente-, introducir un alto y progresivo impuesto global para las grandes fortunas, y también para los altos salarios de los ejecutivos de las trasnacionales. Además de exigir que todos los países aumenten de manera importante el salario mínimo.

El darwinismo social que produce el capitalismo contemporáneo bajo el modo de producción neoliberal, conduce a que las desigualdades se sigan incrementando al punto que llegarán a ser intolerables para todas las naciones. Jurídicamente esto significa enormes dificultades para la realización efectiva del Estado constitucional de derecho porque los derechos econó-

2 Piketty, Thomas, Capital in the Twenty-First Century, Estados Unidos, Harvard University Press, 2014. 
Este libro forma parte del acervo de la Biblioteca Jurídica Virtual del Instituto de Investigaciones Jurídicas de la UNAM

micos, sociales, culturales y ambientales, así como la profundización de la democracia, quedan en meras aspiraciones utópicas.

De esta suerte, estimamos que los escenarios globales futuros implicarán fuertes conflictos de carácter económico, social, político y jurídico. En lo económico, algunos, los privilegiados, intentarán mantener sus beneficios, aún con el respaldo de la fuerza y la coerción; mientras que los menos privilegiados buscarán poner fin al capitalismo global, y probablemente, a todo modo de capitalismo para transitar a formas diversas de vida económica, siendo una de sus posibilidades, la instauración de un socialismo democrático. En lo social, no es impensable que existan conflictos fuertes entre clases, sectores, pueblos y naciones, que pueden dirimirse por medios pacíficos pero también a través de esquemas de luchas violentas y revolucionarias. Políticamente, el debate consistiría en escoger entre las actuales formas de democracia representativa de baja intensidad o entre formas de democracia radical hoy desconocidas, que permitan a los ciudadanos de los Estados y del planeta, definir su destino mediante su participación efectiva y permanente. Jurídicamente, el conflicto versaría sobre las posibilidades de un constitucionalismo global que garantice y haga exigibles los derechos de igualdad.

Nadie conoce el desenlace ni el peso que tendrán las variables observadas en estos años, que pueden influir en la permanencia de lo que llamamos Estado: el cambio climático; la escasez de agua, energía y alimentos; las migraciones continentales masivas; las nuevas revoluciones tecnológicas; los cambios científicos en la genética y en la informática; los nuevos alineamientos hegemónicos entre las naciones, entre otros factores observables. En este marco prospectivo también es posible que el Estado neoliberal transite a otras formas de Estado que mantengan el modo de producción capitalista bajo estructuras menos gravosas socialmente permitiendo la construcción de nuevas formas de Estado.

Esta última reflexión ilustra que el Estado-nación no es eterno y el modelo neoliberal de Estado lo es aún menos. El sistema mundializado o globalizado limita la autonomía y las posibilidades de la soberanía estatal como se entendió en el pasado. ¿Por qué? Porque las decisiones nacionales más importantes no se adoptan por las sociedades locales sino en instancias externas; porque la regulación jurídica nacional se debe adecuar a las necesidades del capitalismo mundial; porque la regulación trasnacional se considera jerárquicamente superior a la nacional, y por tanto, esa regulación no puede ser transgredida sin graves consecuencias para el Estado-nación, y porque las redes de regulación jurídica mundial complejizan y obstaculizan 
Este libro forma parte del acervo de la Biblioteca Jurídica Virtual del Instituto de Investigaciones Jurídicas de la UNAM

el funcionamiento de las autoridades locales que aparecen desconcertadas ante las realidades del nuevo derecho trasnacional.

Las posiciones sobre la globalización neoliberal son divididas por los estudiosos en tres: ${ }^{3}$ la hiperglobalista o globalista, la escéptica y la transformacionalista. Desde la visión de los hiperglobalistas, la globalización se define como una nueva época de la historia humana en la que los Estadosnación son insostenibles en la nueva economía mundial. Las características generales de la concepción hiperglobalista son: un reordenamiento de la acción humana que piensa y actúa, cada vez más, en términos globales; una era global y no nacional; capitalismo global, gobierno global y sociedad civil global; poder del Estado-nación en declive; las fuerzas conductoras de la globalización son el capitalismo neoliberal y la tecnología; erosión de las jerarquías nacionales; cultura mundial y no nacional; una trayectoria sostenida hacia una civilización global, y como última etapa, el fin del Estadonación.

Para los escépticos, el Estado-nación no ha perdido el poder, sigue siendo uno de los actores fundamentales para que el orden global funcione, aunque la tesis admite que el poder del Estado se ha reconfigurado con el propósito de proteger las economías que representan a la internacionalización con mayor fuerza. Los escépticos consideran que la globalización es una ideología o un mito necesario de los neoliberales para que los gobiernos nacionales disciplinen a sus ciudadanos, y así, satisfagan las exigencias del mercado neoliberal, que consisten en eliminar todos los obstáculos que se pretenda imponer a los intereses globales.

Los transformacionalistas consideran que la globalización reconfigura el poder en su conjunto - nacional y mundial- . La posición transformacionalista afirma que el derecho debería yuxtaponerse y entenderse en relación con la jurisdicción en expansión de las instituciones de la gobernanza internacional y con las constricciones del derecho internacional, así como con las obligaciones que de él se derivan. La globalización implica relajación de la relación entre soberanía, territorialidad y poder político. Las ideas transformacionalistas las podemos caracterizar de la siguiente forma: el poder de los gobiernos nacionales y de las instancias mundiales se reestructuran para adaptarse a las nuevas circunstancias globales; se propende a constituir una nueva arquitectura del orden mundial; la globalización transforma el poder estatal y la política mundial, y por último, los resultados de los procesos de globalización son inciertos.

3 Held, David, y McGrew, Anthony, Globalización-antiglobalización. Sobre la reconstrucción del orden mundial, Barcelona, Paidós, 2003. 
Este libro forma parte del acervo de la Biblioteca Jurídica Virtual del Instituto de Investigaciones Jurídicas de la UNAM

Las tres posiciones coinciden en tres aspectos que son torales para la argumentación que hacemos en estas páginas: la globalización se acuerda y se define por las élites económicas y políticas, tanto mundiales como nacionales; en los procesos de globalización no participan, activa ni extendidamente, las ciudadanías nacionales, y finalmente, los procesos de globalización condicionan o reconfiguran al Estado-nación y a los órdenes jurídicos nacionales y mundiales en beneficio de los intereses económicos trasnacionales.

Cada forma de Estado que se estudia en este libro tiene una finalidad que muestra no sólo el condicionamiento de la economía sobre el derecho, sino que busca explicar las notas que determinan jurídicamente a esta estructura de Estado. En el Estado absoluto se describe el proceso de su nacimiento, su constitución mediante la emancipación del feudalismo, y también se exponen sus elementos distintivos: ausencia de derechos humanos generalizados, inexistencia del principio de división de poderes y del principio de legalidad, como lo conocemos ahora. En el Estado liberal de derecho, producto de cambios económicos que reclamaron el libre mercado sin intervención del Estado, encontramos algunas notas del Estado de nuestro tiempo: 1) declaraciones de derechos humanos; 2) división de poderes; 3) principio de legalidad; 4) control de los actos de la administración vía el principio de legalidad, y 5) la existencia de jueces independientes. Estas categorías jurídicas a su vez suponían otras, como la existencia de algunas autoridades representativas electas por los ciudadanos mediante los partidos de notables y el voto censitario; además del principio de autonomía de la voluntad, que permitía a los súbditos o ciudadanos, según fuera el caso, celebrar todos los actos jurídicos que consideraran necesarios y que no estuviesen prohibidos por la ley.

El Estado del bienestar se apoya en categorías jurídicas precisas: 1) reconocimiento constitucional y legal de los derechos económicos, sociales, culturales, y posteriormente ambientales, y de otras generaciones de derechos, aunque con garantías institucionales deficientes; 2) crecimiento de la administración pública, de la burocracia y del gasto público del Estado para satisfacer los derechos reconocidos; 3) principio de legalidad matizado por disposiciones administrativas reglamentarias que reciben de la ley y a favor de la administración pública una delegación de competencias; 4) comienzo de entendimiento de la Constitución como normativa y no sólo nominal o semántica; 5) fortalecimiento del control de constitucionalidad y de los jueces constitucionales; 6) nuevas concepciones sobre la ciencia jurídica y la validez jurídica; 7) mayor peso de los tratados sobre derechos humanos en el derecho interno; 8) sistema democrático pluralista; 9) debate entre la 
Este libro forma parte del acervo de la Biblioteca Jurídica Virtual del Instituto de Investigaciones Jurídicas de la UNAM

capacidad de transformación o de pacificación de la Constitución sobre el sistema económico-social, y 10) el logro del Estado del bienestar a través de la legislación fiscal y presupuestal.

En el Estado constitucional, que es una ficción jurídica muy potente, elaborada teóricamente sin justificación económica y política, encontramos estas características: 1) conexión en diversos grados, según el autor y corriente, entre el derecho y la moral; 2) los derechos humanos son el fundamento y el fin del Estado y el derecho; 3) las Constituciones expresan principios y proyectos jurídicos y políticos contrapuestos, ninguno prevalece a priori sino en la aplicación de los casos concretos; 4) reconocimiento de que el derecho está conformado por multitud de materiales normativos, fundamentalmente por reglas, principios y valores; 5) orientación hacia la Constitución normativa, es decir, a la unión entre el deber ser de la norma y la realidad; 6) el derecho no sólo consiste en una estructura normativa sino también argumental, contextual y procedimental; 7) la legalidad y el resto de las fuentes jurídicas se supedita a la convencionalidad y a la constitucionalidad en un sentido fuerte; 8) las normas que no son reglas no se pueden interpretar por los métodos tradicionales, es preciso acudir al principio de proporcionalidad y a otras formas de argumentación para resolver las colisiones entre principios opuestos; 9) el ordenamiento jurídico se interpreta desde la Constitución para maximizar los derechos fundamentales; 10) la certeza jurídica se vuelve más exigente y difícil, se apoya, principalmente en la calidad de la argumentación; 11) la Constitución es una norma directamente aplicable por todas las autoridades y rígida, existen principios que no pueden reformarse utilizando el procedimiento constitucional de revisión constitucional; 12) el juez constitucional es el garante del Estado constitucional y carece de legitimidad democrática de origen, la busca suplir a través de la calidad argumentativa de sus resoluciones; 13) se pretende globalizar el constitucionalismo, pero sin éxito, porque el Estado constitucional no tiene una teoría económica y política que le otorgue fundamento; 14) la democracia constitucional no se origina en la regla de la mayoría, sino en el respeto y garantía de los derechos humanos, las mayorías son un fragmento de la soberanía popular, y 15) se trata de un Estado que no es neutral ni valorativo. Su ideología es la de los principios y valores contrapuestos, que se contienen en la Constitución y en los tratados sobre derechos humanos. Sin embargo, éstos no siempre son realizados, principalmente los que expresan derechos económicos, sociales, culturales y ambientales.

El Estado neoliberal somete al Estado-nación a las exigencias económicas, políticas y jurídicas de la globalización neoliberal. Estimamos que sus notas más relevantes son en el orden interno las siguientes: 1) poderes fácti- 
Este libro forma parte del acervo de la Biblioteca Jurídica Virtual del Instituto de Investigaciones Jurídicas de la UNAM

cos nacionales y trasnacionales sin límites y controles jurídicos suficientes; 2) derechos fundamentales sin garantías plenas de realización, principalmente respecto a los derechos económicos, sociales, culturales y ambientales; 3) débil democratización, transparencia, rendición de cuentas, eficiencia y eficacia de las instituciones del Estado y de las trasnacionales; 4) supremacía de los tratados internacionales, principalmente los relacionados con el comercio, las inversiones y la propiedad, por encima de las Constituciones nacionales; 5) mecanismos débiles de derecho procesal constitucional para no proteger con suficiencia los derechos fundamentales de carácter social ni los derechos colectivos; 6) instrumentos anticorrupción compatibles con los intereses de las grandes corporaciones trasnacionales; 7) reducción de la democracia participativa, deliberativa, y comunitaria, y con ello, impulso de una democracia electoral manipuladora de los derechos políticos de los ciudadanos; 8) entrega del patrimonio de las naciones - sus recursos naturales - y de su explotación a los intereses foráneos; 9) inadecuada defensa de la soberanía nacional, y 10) implantación del modelo económico neoliberal globalizador para someter al derecho y al Estado nacional en su provecho.

Además de explicar las características jurídicas de cada forma de Estado, realizamos la crítica a cada uno de los elementos. Apreciamos, después del análisis de las distintas formas de Estado que han acompañado al Estado-nación, que en el futuro surgirán nuevas estructuras y categorías de explicación para nuevos tipos de Estado, de acuerdo con la evolución de la economía, la sociología y la política mundial y nacional, y desde luego, de conformidad con la evolución de las culturas jurídicas particulares.

El ensayo que se somete a la benevolencia de los potenciales lectores, creo que nos recuerda una vez más, la complejidad del conocimiento. No puede estudiarse un objeto desde una disciplina particular. En el caso del Estado-nación y su evolución jurídica es imprescindible contar con el respaldo de otras ciencias como la economía y la sociología. Sin esas herramientas conceptuales cualquier estudio deviene en un formalismo que carece de utilidad para la comprensión.

Agradezco al Instituto de Investigaciones Jurídicas de la UNAM y al doctor Pedro Salazar, su director, la oportunidad de publicar estas líneas bajo el sello y cuidado de nuestra máxima casa de estudios. 
Este libro forma parte del acervo de la Biblioteca Jurídica Virtual del Instituto de Investigaciones Jurídicas de la UNAM

\section{CAPÍTULO PRIMERO \\ ORÍGENES Y TRANSFORMAGIONES DEL ESTADO MODERNO}

\section{REALIDAD Y MÉTODOS DEL ESTADO MODERNO}

Conviene tener presente que lo que llamamos Estado es, o fue, por un lado, una serie de teorías y pensamientos filosóficos sobre una realidad variable - más amplia o restringida, según el método que se siga -, y por otro, una realidad que se expresa en elementos tales como una población en un territorio, con un gobierno que se ejerce a nombre de ella y en donde la autoridad pretende contar con el monopolio de la fuerza legítima. Hoy en día, el Estado moderno, surgido de la transformación del pasado feudal y expresado inicialmente en monarquías absolutas, ha perdido la consistencia en muchos de sus elementos tradicionales; en nuestros días, por el efecto de la globalización neoliberal, y antes de esta fase, porque el Estado no cumplía los fines para los que había sido creado, o bien, porque sus fundamentos eran considerados mitológicos. ${ }^{4}$ Lo cierto es que en nuestra época, las decisiones más importantes que adoptaba el Estado-nación se aprueban en sedes extra-nacionales, sin intervención de las sociedades, de manera opaca y a veces sin el consentimiento de los gobiernos nacionales.

Las teorías y reflexiones sobre la realidad que llamamos el Estado parten de diversos métodos que estudian su objeto flexible, que como dijimos, ha variado en sus contenidos y orientaciones desde su aparición moderna en el Renacimiento, pero que invariablemente ha estado vinculada al desarrollo del capitalismo. Los métodos que se emplean para estudiar lo que de-

4 Ver la obra publicada inicialmente en 1946 de Cassirer. Cassirer, Ernst, El mito del Estado, México, Fondo de Cultura Económica, 1982; García Pelayo, Manuel, Los mitos políticos, Madrid, Alianza Editorial, 1981, p. 23. Dice García Pelayo que las ideas y conceptos pueden expresarse en forma racional o mítica. El mito no trata de satisfacer una necesidad de conocimiento sino una necesidad existencial de instalación y de orientación ante las cosas, fundamentada en la emoción, en el sentimiento y, en algunos casos, en profundas intuiciones. En el mito es esencial que constituya "una realidad vivida". 
Este libro forma parte del acervo de la Biblioteca Jurídica Virtual del Instituto de Investigaciones Jurídicas de la UNAM

nominamos Estado moderno presentan también diferencias en cuanto a la congruencia interna de sus enunciados; los procedimientos de verificación de esos enunciados; las capacidades descriptivas, explicativas y predictivas de los enunciados; así como las posibilidades de esos enunciados para ser transmitidos a la comunidad científica o a la sociedad.

Los métodos para estudiar teóricamente el Estado están determinados por el conocimiento que más influye en ese análisis. ${ }^{5}$ Diversas ciencias sociales lo estudian bajo perspectivas propias: el derecho, la economía, la sociología, la ciencia política, la historia, la antropología y las relaciones internacionales. Esos estudios pueden ser descriptivos y analíticos, normativos, aplicativos y críticos. Serán descriptivos para aproximarnos mediante la observación y el lenguaje a lo que llamamos Estado; serán normativos para proponernos cómo debiera ser el Estado; serán aplicativos si pretendemos mejorar las instituciones y reglas que permiten el funcionamiento del Estado, y serán críticos si cuestionan los elementos de su existencia y proponen formas de organización humana distintas. Desde luego, que con fundamento en lo dicho, se podrían proponer teorías integrales del Estado que tomaran en cuenta todo lo anterior.

Entre los métodos formalistas para el estudio del Estado están los de Gierke, Gerber, Laband, Santi Romano, Mortati y principalmente Kelsen. Para este autor, no hay más teoría del Estado que la teoría del Estado de derecho, porque el Estado no es otra cosa que el propio derecho. El ámbito de lo político es previo y sus consecuencias irrelevantes para la concepción monista, jurídico-formal, que se limita al análisis del ordenamiento jurídico del Estado. ${ }^{6}$

Los métodos sociológicos como el de Hermann Heller exponen el carácter de clase del Estado y pueden entender que éste sea un instrumento de dominación de las clases dominantes sobre las dominadas. No pueden permitirse el lujo de proclamar la neutralidad y asepsia del Estado como lo hacen los métodos jurídico-formales. Sin embargo, el método sociológico carece de la capacidad para cuestionar lo existente, el statu quo, porque su preocupación consiste en explicar lo qué es ${ }^{7}$ y no lo que debe o debería ser.

5 Heller, Hermann, Teoría del Estado, México, Fondo de Cultura Económica, 2014, pp. 54 y ss.

6 Kelsen, Hans, Teoría general del derecho y del Estado, México, UNAM, 2010; mismo autor, Problemas capitales de la teoría jurídica del Estado, México, Porrúa, 1987.

7 Por ejemplo, Durkheim considera que el Estado surge cuando una población se identifica con un territorio. Posteriormente, los grupos que conforman la sociedad se someten a una autoridad que no depende de ninguna otra superior. A medida que el Estado se vuelve más complejo, los funcionarios adoptan decisiones que comprometen a la colectividad y bien 
Este libro forma parte del acervo de la Biblioteca Jurídica Virtual del Instituto de Investigaciones Jurídicas de la UNAM

Con este método se estudian las motivaciones humanas de carácter colectivo que sostienen lo que llamamos las instituciones y elementos del Estado. ${ }^{8}$

Georg Jellinek procuró en 1990 — antes de la obra de Heller - realizar una síntesis entre la concepción jurídico-formal alemana del siglo XIX y la nueva concepción sociológica del Estado. En la obra de Jellinek existe un doble análisis: el sociológico, para estudiar el carácter dinámico y volitivo de los hechos sociales que tienen que ver con el Estado, y el jurídico, para conocer las instituciones y normas que conforman al Estado. ${ }^{9}$ Más tarde Hauriou, pretenderá ese equilibrio entre constitucionalismo formal y vida institucional. ${ }^{10}$

Entre los conductistas, como los de la ciencia política norteamericana, las leyes y tesis principales sobre el Estado deben ser consecuencia de la observación empírica de instituciones específicas como el sistema de partidos, el sistema electoral, los sistemas de gobierno, etcétera. En esos estudios de carácter comparado suelen no estudiarse lo que se encuentra detrás o es el sustrato del Estado, pues no puede observarse. Como evolución de este empirismo está el método que concibe el estudio del Estado a partir de modelos aproximativos de su complejidad, construidos a partir de algunas variables que se consideran determinantes. ${ }^{11}$

Hay métodos semiológicos, interesados en establecer los orígenes, fines y sentidos de eso que llamamos Estado. En algunos se propone regresar a sociedades prepolíticas, sin Estado, sin ningún tipo de jerarquía, atribución de mando y autoridad (visiones antropológicas). En la época del Estado absoluto, a diferencia de autores como Maquiavelo, algunos proclamaron (espejos de príncipes) que el fin del Estado era cumplir con los designios divinos. En las teorías del contrato social o del pacto, el origen y fin del Estado radica en un acuerdo de conveniencia (para garantizar la seguridad, la libertad, la igualdad, etcétera). Para el pensamiento conservador, Burke y sus seguidores, el Estado es un fenómeno de la historia que está ahí para salvaguardar las tradiciones y la propiedad privada. En el marxismo y en el anarquismo, el Estado es el instrumento de la violencia que se orienta a

se puede decir que el Estado es un órgano especial encargado de elaborar representaciones que valen para toda la colectividad. La justificación del Estado, lo que le da sentido y razón de ser, son objetivos como los derechos humanos y el logro del bien común. Durkheim, Emilio, Lecciones de sociología, Pléyade, Buenos Aires, 1974, pp. 90 y ss.

8 Heller, Hermann, Teoría del Estado, op. cit., pp. 256 y ss.

9 Jellinek, Georg, Teoría general del Estado, México, Fondo de Cultura Económica, 2012.

10 Hauriou, Maurice, Principios de derecho público y constitucional, Granada, Comares, 2003.

11 Lijphart, Arend, "Comparative Politics and the Comparative Method", American Political Science Review, vol. 65, núm. 3, septiembre 1971, pp. 682-693. 
Este libro forma parte del acervo de la Biblioteca Jurídica Virtual del Instituto de Investigaciones Jurídicas de la UNAM

favor de las clases dominantes. El anarquismo reclama la destrucción inmediata del Estado, y el marxismo entiende que además de ser un instrumento de dominación de clase, ${ }^{12}$ es el espacio en el que se ventila la lucha de clases en sociedades previas al comunismo, y que además, constituye un modo de producción específico (el del capitalismo).

En el pensamiento gramsciano, el Estado representa la expresión de una hegemonía ideológica que se ha impuesto a las demás y que en este momento histórico sirve al capitalismo. ${ }^{13}$ Esa hegemonía dota de legitimidad transitoria a las instituciones y gobernantes, y puede ser sustituida por nuevas hegemonías si éstas tienen la capacidad de imponerse. Gramsci concibe al Estado como un modelo de dominación capitalista que está en permanente situación de cuestionamiento por legitimidades o hegemonías emergentes. ${ }^{14}$

Muchos han cuestionado a Gramsci por sus reservas respecto a la transformación de los regímenes y de los modelos de dominación a través del cambio revolucionario; pues la hegemonía no se identifica con la fuerza, sino con un proceso histórico que se logra mediante alianzas que permite a las sociedades avanzar. Gramsci así, construye la categoría de bloque histórico para explicar el conjunto de fuerzas y relaciones que se conjugan para ejercer la dominación, se trata de crear una coalición política que sirva para promover las relaciones de clase, los vínculos entre las organizaciones sociales con el partido y el Estado; en donde es indispensable el trabajo de los intelectuales orgánicos — los de la burguesía y del proletariado-, además del desarrollo de una política cultural que apoye y cohesione esa alianza. ${ }^{15}$

Durante el siglo XX, algunas visiones revisionistas de la concepción marxista del Estado - Nicos Poulantzas y Ralph Miliband - ${ }^{16}$ sostuvieron que la relación entre el Estado y el capitalismo no era mecánica ni automática. El Estado podía tener autonomía del capitalismo y no era una simple superestructura puesta al servicio de éste. Miliband consideraba que el Estado contaba con un ámbito político de mediación entre las clases sociales y sus intereses y en él se creaban las bases del consenso que hace posible la legitimación y el ejercicio del monopolio de la fuerza por parte del Estado.

12 Marx, Carlos, Crítica de la filosofia del Estado de Hegel, México, Grijalbo, 1968.

13 Soria, Víctor, "Importancia de la teoría gramsciana del Estado para el estudio de la regulación económica y política del capitalismo actual”, en Martinelli, José María (comp.), La actualidad de Gramsci: poder, democracia y mundo moderno, México, Universidad Autónoma Metropolitana, 1995, pp. 107-120.

14 Gramsci, Antonio, La política y el Estado moderno, Barcelona, Península, 1971.

15 Paoli Bolio, Francisco José, Teoría del Estado, México, editorial Trillas, 2009, p. 152.

16 Miliband, Ralph, El Estado en la sociedad capitalista, México, Siglo XXI, 1973; y Poulantzas, Nico, Poder político y clases sociales en el Estado capitalista, México, Siglo XXI, 2007. 
Este libro forma parte del acervo de la Biblioteca Jurídica Virtual del Instituto de Investigaciones Jurídicas de la UNAM

De esta suerte, el Estado sería un mecanismo de lucha entre ideologías, representaciones e intereses diversos. Poulantzas, en crítica con Miliband, también acepta la autonomía relativa del Estado pero para favorecer el papel de la sociedad civil y de sus clases proletarias.

Las anteriores posiciones revisionistas de la concepción marxista del Estado de inspiración gramsciana han sufrido numerosas críticas. Una de ellas es la de Antonio Negri, que insiste en el carácter clasista del Estado y en su imposibilidad para jugar un papel arbitral independiente. Para él, la legitimidad del Estado se basa en la regla capitalista del desarrollo de la explotación, en donde el Estado es la superestructura que lo articula y orienta. Para Negri, las alternativas a la explotación capitalista del Estado están exclusivamente en la lucha radical de los sectores sociales proletarios y críticos en contra de esa estructura de dominación. El papel arbitral, neutro e independiente del Estado es una ilusión idealista y antihistórica. ${ }^{17}$

En las concepciones posmodernas sobre el Estado se puede advertir un enfoque crítico sobre el Estado para deconstruirlo y poner en cuestión lo que oculta y ha representado siempre: la fuerza, la antidemocracia y la injusticia. ${ }^{18}$ El Estado de derecho y la democracia estarían en todo caso por venir, son una simple probabilidad, una idea regulativa. Esta manera de entender lo estatal y lo jurídico entronca con las posturas del marxismo, pero refina y actualiza sus argumentos para proponer formas de emancipación humana futura que permitan la transformación, el cambio o la revolución de eso que llamamos Estado. ${ }^{19}$

Dentro de las concepciones posmodernas de carácter marxista-anarquista, está la visión crítica sobre el Estado de John Halloway que, en su obra Cambiar el mundo sin tomar el poder. El significado de la revolución hoy, expone que tanto los revolucionarios como los reformistas intentaron transformar la realidad a través del Estado, pero ambas posturas han fracasado, porque el Estado no se puede orientar a favor de los proletarios y excluidos, aunque se pretenda. El Estado y el capitalismo están estrechamente vinculados, más allá de lo que se puede suponer. El error de los revolucionarios es tener una visión instrumental de la naturaleza capitalista del Estado y creer que se puede dirigir, al tomar el poder y control de él, en beneficio de las clases proletarias; el de los socialdemócratas, es la de engañarse con las posibilidades de domeñar al Estado capitalista a favor de conquistas sociales.

17 Negri, Antonio, La forma-Estado, Madrid, Akal, 2003, pp. 386 y 387.

18 Derrida, Jacques, Canallas. Dos ensayos sobre la razón, Madrid, Trotta, 2005, pp. 101 y ss.

19 Laclau, Ernesto y Mouffe, Chantal, Hegemonía y estrategia socialista. Hacia una radicalización de la democracia, México, Fondo de Cultura Económica, 2011. 
Este libro forma parte del acervo de la Biblioteca Jurídica Virtual del Instituto de Investigaciones Jurídicas de la UNAM

Halloway considera que el Estado moderno está inmerso profundamente en la red de relaciones sociales capitalistas y que nunca puede instrumentalizarse a favor de los excluidos. Manifiesta que, sobre todo hoy en día, en el mundo de la globalización y el neoliberalismo, las relaciones sociales capitalistas no coinciden con las fronteras territoriales del Estado y las relaciones capitalistas están desterritorializadas reproduciéndose más allá de las fronteras nacionales, al grado de imponerse con lógicas internas pero fundamentalmente externas en el territorio de cada Estado. Afirma que es equivocado pensar que primero se debe ganar el poder y después se puede constituir una sociedad valiosa para la humanidad, pues el realismo del poder sólo reproduce al poder. Encuentra en el movimiento neozapatista un ejemplo de cómo se puede cambiar el mundo sin tomar el poder, sin el Estado, es más, al margen de él. Halloway no propone recetas de cómo cambiar el mundo sin tomar el poder, pero estima que las comunidades y grupos sociales deben trabajar mediante la lucha social, política y económica en ello. Él aprecia que para comenzar, debemos aunar la teoría con el hacer. El hacer es de carácter social y es opuesto al tradicional poder sobre el capitalismo de Estado. En el capitalismo lo hecho está separado del hacer y se vuelve contra él. Halloway asume que la humanidad hoy en día tiene distintos escenarios: a) abandonar la esperanza para que la fuerza y el poder estén siempre presentes; b) olvidar las sutilezas y concentrarse en la naturaleza binaria del antagonismo de clases como sostuvo el marxismo clásico, y c) no perder la esperanza, lo que implica resistir y negar al capitalismo y al Estado, pues en las sociedades de nuestro tiempo, estamos obligados a entender lo que es negado, excluido, marginado. Como miembros de las comunidades debemos participar en el antagonismo y en la lucha permanente contra los sistemas de opresión capitalista. Su propuesta es: “...pelear por medio de la crítica para recuperar el hacer". ${ }^{20}$

Sin que se trate de un método más, ni del último, encontramos también hoy en día, las explicaciones geopolíticas del Estado, que son parte de las reflexiones sobre el Estado neoliberal. Un Estado que modifica y actualiza las circunstancias del presente, sus características de dominación política y económica, y sirve fundamentalmente al capital trasnacional y a los poderes que gobiernan nuestro mundo, obviamente carente de legitimidad

20 Halloway, John, Cambiar el mundo sin tomar el poder. El significado de la revolución hoy, Caracas, Venezuela, Vadell Hermanos, C. A., 2005, pp. 15-220. También ver el prefacio de John Halloway al libro de Matamoros Ponce, Fernando, Memoria y utopía en México. Imaginarios en la génesis del neozapatismo, Xalapa, México, Universidad Veracruzana y Benemérita Universidad Autónoma de Puebla, 2005, pp. 23-25. 
Este libro forma parte del acervo de la Biblioteca Jurídica Virtual del Instituto de Investigaciones Jurídicas de la UNAM

democrática y de transparencia y que prescinde de las sociedades humanas que lo habitan. ${ }^{21}$

\section{EL NACIMIENTO DEL ESTADO MODERNO}

Generalmente se considera que el Estado moderno nace con el Renacimiento. Sin embargo, en el pasado histórico existieron formas de organización política basadas en la unidad territorial, en la existencia de ejércitos permanentes y/o, en la existencia de una hacienda pública. A diferencia de esas formas pre-estatales, en donde podía existir una o algunas de esas características, el Estado moderno reúne todas las anteriores condiciones; incluso incorpora otras, como la existencia de un orden jurídico exclusivo y uniforme aplicable a un gran territorio y categorías jurídico-políticas como la soberanía y el monopolio de la fuerza legítima.

Las formas pre-estatales y el Estado moderno tienen en común ser, desde nuestro punto de vista, instrumentos de dominación política, pero su diferencia específica radica en el modo de producción económica dominante. El Estado moderno es una forma de dominación política con un modelo de producción capitalista; en donde para algunos teóricos, la explotación económica no tiene que recurrir directamente a la dominación política para realizarse..$^{22}$ Nosotros, por el contrario, pensamos que la ficción que separa el mundo económico y el político es bastante cuestionable, porque en última instancia el Estado tiene los instrumentos para recurrir a la violencia - legítima o no-, y con ello, sostener o apuntalar al modo de producción capitalista. Aunque es verdad que la legitimidad del Estado moderno se busca imponer, generalmente, no por la fuerza física sino por la aceptación al poder. ${ }^{23}$

21 Harvey, David, Breve historia del neoliberalismo, Madrid, Akal, 2013, pp. 73 y ss.

22 Pérez Royo, Javier, Introducción a la teoría del Estado, Barcelona, Blume, 1980, pp. 111.

23 Existen muchas aproximaciones para entender y definir poder. Una de ellas, la más elemental y socorrida, entiende que alguien tiene poder sobre otro cuando prevalece su interés y logra influir en sus decisiones. Otro enfoque señala que alguien tiene poder no sólo cuando influye en el otro e impone su interés, sino también, cuando logra evitar conflictos y excluye de la agenda pública los intereses del otro. También se entiende que el poder significa la capacidad para moldear los intereses de los otros e influir en los arreglos suscitados por los conflictos. Igualmente algunos consideran que el poder deviene de la inacción de los sin poder, y por eso, conviene estudiarlo cuando los sin poder tienen la capacidad de cambiar su situación política. Steven, Lukes, El poder: Un enfoque radical, Madrid, Siglo XXI Editores, 2007; y Gaventa, John, Power and Powerlessness. Quiescence and Rebellion in an Appalachian Valley, Estados Unidos, University of Illinois Press, 1982. 
Este libro forma parte del acervo de la Biblioteca Jurídica Virtual del Instituto de Investigaciones Jurídicas de la UNAM

Entre las formas pre-estatales, que han sido clasificadas por Bernard Crick, encontramos las siguientes: gobierno primitivo, imperios antiguos, ciudades griegas, Roma republicana, Roma imperial, despotismo oriental, gobierno feudal y el primitivo Estado moderno. ${ }^{24}$

La teoría marxista distinguió, previos al capitalismo, los siguientes modos de producción:

1) El modo de producción de la comunidad primitiva, en donde del mundo nómada se articularon formas de propiedad comunal no privada, y en su evolución, pasó por la institucionalización de formas familiares patriarcales, en las que los marcos de dominación política residen en los jefes de las familias y clanes.

2) El modo de producción asiático combina el derecho de propiedad del rey sobre las tierras con la existencia de comunidades primitivas en las que prevalece la posesión común del suelo y los grupos humanos se organizan todavía sobre las relaciones de parentesco. El Rey controla el uso de los recursos económicos esenciales y se apropia directamente de una parte del trabajo y de la producción de las comunidades que domina.

3) El modo de producción esclavista engloba cuatro formas políticas pre-estatales, la polis griega, la República romana, las monarquías helenísticas y el Imperio romano. La esclavitud es la relación de producción dominante en esta etapa y produce la riqueza para los dueños de los esclavos y para los gobernantes.

4) El modo de producción feudal se apoya en:

- Una forma de explotación de la tierra - que pertenece al señor feudal- y que realizan siervos y ya no esclavos, los que reciben algunas prebendas.

— Además existe un vínculo de vasallaje entre el señor y los siervos.

-El sistema político feudal se encuentra claramente jerarquizado desde el siervo de la gleba al Emperador. ${ }^{25}$

Para entender mejor el nacimiento del Estado moderno de corte absoluto, ${ }^{26}$ conviene explicar con algo más de detalle las notas de la dominación feudal. Entre las características del feudalismo encontramos que: a)

24 Crick, Bernard, Basic Forms of Government: a Sketch and a Model, Londres, MacMillan, 1973.

25 Godelier, Maurice, Teoría marxista de las sociedades precapitalistas, Barcelona, Laia, 1977, p. 149 y ss.

26 Anderson, Perry, Transiciones de la antigüedad al feudalismo, Madrid, Siglo XXI, 1980. 
Este libro forma parte del acervo de la Biblioteca Jurídica Virtual del Instituto de Investigaciones Jurídicas de la UNAM

la dominación feudal era ejercida por personas que imponían sus objetivos mediante rituales en el ejercicio de la función jurisdiccional y el poder de las armas. El orden de dominación y la práctica política quedaban definidos por relaciones interpersonales y no formales ni generales; $b$ ) el espacio al que se circunscribía el régimen señorial era la tierra, que no representaba un área concreta, sino un espacio político, social y económico, en el que regía un derecho único; c) el derecho era entendido como ordenamiento de inspiración divina y se consideraba inviolable. Las infracciones a la ley permitían el castigo de los afectados mediante desafíos; $d$ ) el sistema feudal fraccionaba el poder en distintos señores feudales, y el rey no ejercía poder soberano alguno. Los señores feudales disponían de derechos de señorío autónomos al poder del rey y del emperador; $e$ ) el objetivo del régimen feudal era la protección de las personas, que en contraprestación debían a su señor fidelidad y apoyo. Señores feudales y vasallos se controlaban recíprocamente, y f) la voluntad política última descansaba en los acuerdos que adoptaban los señores feudales, y los conflictos entre ellos, se zanjaban mediante negociaciones secretas con intervención de mediadores. ${ }^{27}$

En resumen, en el mundo feudal, el modo de producción estaba basado en la explotación a los siervos de la gleba por los señores feudales. Era un marco de relaciones en donde en la vida secular no existía una institucionalización formal del poder, ni el monopolio de la violencia legítima, ni una administración organizada, ni un derecho escrito, ni soberanía sobre un territorio. Adicionalmente, frente a los señores feudales y los siervos de la gleba se encontraba la Iglesia, con una organización de poder propia y fuertemente centralizada, con su propio ordenamiento jurídico y una administración estable y bastante desarrollada. ${ }^{28}$

Como ha señalado Hermann Heller, ${ }^{29}$ hacia 1302 aparecen los primeros visos de la aparición del Estado moderno. En ese año se da el quiebre de la supremacía papal porque Felipe el Hermoso de Francia niega obediencia a la encíclica Unam Sanctam. La Iglesia comienza a perder terreno en sus pretensiones universalistas en materia cultural ideológica y con ello inicia el proceso de secularización que llevaría a la Reforma. La consecuencia de la Reforma implicaría la emancipación paulatina de las organizaciones políticas existentes del poder de la Iglesia. Así, por ejemplo, la filosofía política

27 Benz, Arthur, El Estado moderno. Fundamentos de su análisis politológico, Madrid, Centro de Estudios Políticos y Constitucionales, 2010, pp. 30 y 31.

28 Ibidem, p. 31.

29 Heller, Hermann, Teoría del Estado, cit., p. 167. 
Este libro forma parte del acervo de la Biblioteca Jurídica Virtual del Instituto de Investigaciones Jurídicas de la UNAM

comenzaría a buscar nuevas fuentes de legitimidad del poder que ya no residen en un fundamento divino.

El proceso de construcción del Estado moderno es largo y confluyeron en su aparición una serie de causas, entre las que se enumeran: a) el descubrimiento de nuevas fuentes de riqueza, tanto del viejo como del nuevo continente; $b$ ) el desarrollo de las finanzas internacionales, primero en Italia y después en los Países Bajos; c) la revolución de los métodos de cultivo y con ello la distribución de la propiedad territorial, lo que comenzó a poner en jaque a la propiedad feudal; $d$ ) el descubrimiento y difusión de la imprenta, lo que significó el fin del monopolio de la Iglesia; e) el descubrimiento y desarrollo de la pólvora que democratizó el acceso a las armas de fuego; $f$ ) la constitución de ejércitos nacionales en manos de algún o algunos de los señores feudales más fuertes, y $g$ ) la reforma protestante y su impronta secularizadora. ${ }^{30}$

En el trayecto del surgimiento del Estado moderno, los medios de autoridad y administración de carácter privado, se convirtieron en propiedad pública. El poder de mando se expropió primero en beneficio del príncipe absoluto y luego a favor del Estado. Es en esta época cuando se conforman los ejércitos permanentes, la hacienda pública se nutre con impuestos aprobados sin el consentimiento de los viejos estamentos, y la burocracia y sus respectivas organizaciones y funcionamiento, pasan a manos públicas: del príncipe o del Estado. Parte de este proceso es la creación de un patrimonio del Estado, independiente del patrimonio de los señores feudales o del rey, que entre otras cosas, contribuye a transformar el sistema económico feudal y sustituirlo por uno capitalista.

El establecimiento del Estado concluye formalmente con la existencia de un único ordenamiento jurídico válido para todos los habitantes del territorio que integra el Estado. El Estado moderno tendrá entre sus características fundamentales ser en sí mismo un sujeto especial de derecho que se organiza jurídicamente y que tiene el monopolio de la producción de las normas que regirán la vida de los gobernados y de las propias instituciones del Estado.

Podemos decir, en síntesis, que las principales características formal-institucionales - no económicas - del Estado moderno en su evolución histórica, y hasta antes de la aparición del neoliberalismo globalizador, han sido: a) ser un Estado territorial, pues su poder se extiende sobre un territorio en el que sólo él tiene la capacidad de ejercitar el poder supremo y en el

30 Laski, Harold J., El liberalismo europeo, México, Fondo de Cultura Económica, 2012, pp. 11-75; y, Heller, Hermann, Teoría del Estado, op. cit., pp. 165-181. 
Este libro forma parte del acervo de la Biblioteca Jurídica Virtual del Instituto de Investigaciones Jurídicas de la UNAM

que permanece al margen de las influencias exteriores; b) el Estado es el conjunto de ciudadanos que pueblan su territorio y que se constituyen en pueblo o nación política; c) el Estado es unidad organizada de decisión y funcionamiento, ya que dispone del poder legislativo, del ejército, del ejercicio de la coerción legítima y de proveer los bienes y servicios públicos a los ciudadanos; d) el fundamento formal institucional del Estado es el ordenamiento jurídico y ahora la Constitución, que otorga fundamento jurídico a su actuación; e) la estructura política del Estado es la democracia, aunque sea ésta una cuestión puramente formal, pues las decisiones de los órganos y poderes tienen que basarse en la voluntad del pueblo, y $f$ ) la actividad del Estado dice consistir, aunque ello no sea verdad, en cumplir la voluntad popular determinada en un proceso democrático, a través de una organización gubernamental y administrativa denominada burocracia, heredera de la administración de los monarcas absolutos, en donde esta forma de organización, está inspirada en la previsibilidad de sus actos, que son susceptibles de control jurídico. ${ }^{31}$

En el ámbito de las relaciones internacionales derivadas de la Paz de Westfalia (1648), los Estados europeos, durante mucho tiempo, no reconocieron autoridad superior a ellos. Se decía que acordaban o competían entre sí. Si convenían lo hacían a través del tratado; si competían, lo hacían militarmente, por medio de la guerra. Las regulaciones internacionales, hasta antes de las guerras mundiales del siglo XX no pretendían otra cosa que garantizar las condiciones mínimas de coexistencia entre los Estados. Los Estados eran considerados formalmente iguales en soberanía, con independencia de su poder efectivo, de su población o de su extensión territorial. ${ }^{32}$

Para la filosofía marxista, el énfasis sobre el origen del Estado moderno está puesto, más que en los anteriores elementos institucionales, en los antagonismos sociales y en el poder de la clase dominante ascendente sobre las dominadas. Sin embargo, lo más importante es que el Estado moderno es el instrumento para explotar a la clase oprimida dentro del modo de producción capitalista. La explotación determina al Estado; sólo si hay explotación habrá Estado. Según Engels, el Estado se caracteriza: a) por la naturaleza de clase de todo Estado; b) el binomio dominación-explotación - en el caso del

31 Benz, Arthur, El Estado moderno..., cit., pp. 65 y 66.

32 Gabriel, José Antonio de, "La formación del Estado moderno", en Águila, Rafael del, Manual de ciencia política, Madrid, Trotta, 1997, p. 43. 
Este libro forma parte del acervo de la Biblioteca Jurídica Virtual del Instituto de Investigaciones Jurídicas de la UNAM

Estado moderno por la explotación capitalista-; c) la organización territorial, y d) la institucionalización de la fuerza pública en el Estado. ${ }^{33}$

En la teoría marxista se busca cerrar el proceso histórico de construcción del Estado, pues se pone de manifiesto su carácter histórico de herramienta de la clase capitalista, ${ }^{34} \mathrm{y}$ al mismo tiempo, su naturaleza transitoria y tendente a su extinción en la sociedad comunista. En esta postura, lo fundamental es explicar el desarrollo histórico de los modos de producción y de los tipos de sociedad y de organización política que generan. Además, se quiere la transformación y destrucción del Estado - porque sólo sirve a las clases dominantes - para arribar a condiciones humanas mejores y distintas.

Podemos decir que la teorización marxista sobre el Estado puede resumirse con estos tres elementos: a) el Estado es una ideología al servicio de las clases dominantes; b) el Estado posee capacidad de hegemonía para imponerse sobre las clases dominadas (el proletariado), y por tanto, tiende a la conservación y a la continuidad, a menos que las clases dominadas, previa su organización y conscientes de sí, lo transformen o destruyan, y c) el origen del Estado, sus transformaciones, desarrollo material-histórico y su posible extinción futura, obedecen a la lucha de clases entre los grupos sociales. ${ }^{35}$

La conceptualización marxista del Estado no es totalmente opuesta a la weberiana en algunas variables de la definición de Weber, principalmente en su caracterización del Estado moderno como un "....instituto político de actividad continuada, cuando y en la medida en que su cuadro administrativo mantenga con éxito la pretensión al monopolio legítimo de la coacción física legítima para el mantenimiento del orden vigente". ${ }^{36}$ En este sentido, el Estado weberiano es una forma de organización política esencialmente posfeudal caracterizada por un orden administrativo y legal sujeto a cambios mediante legislación, al cual se orientan las actividades organizadas por la burocracia

33 Engels, Friedrich, El origen de la familia, la propiedad y el Estado, Madrid, Fundamentos, 1970, p. 212.

34 Sweezy, Paul M., Teoría del desarrollo capitalista, México, Fondo de Cultura Económica, 1981, pp. 265-279.

35 Marx señala cómo la acumulación originaria que da lugar al capitalismo se valió de distintos sistemas jurídicos, políticos y económicos para consolidarse: el colonial, el de la deuda pública, el tributario, el proteccionista, entre otros. En todos los casos, el poder del Estado se empleó como un instrumento y herramienta de clase y sirvió para respaldar esos métodos y sistemas en beneficio de la burguesía y de la consolidación del capitalismo. Marx, Carlos, El capital, México, Fondo de Cultura Económica, 1979, t. I, pp. 638 y 639.

36 Weber, Max, Economía y sociedad, edición revisada, comentada y anotada por Francisco Gil Villegas, México, Fondo de Cultura Económica, 2014, p. 185. 
Este libro forma parte del acervo de la Biblioteca Jurídica Virtual del Instituto de Investigaciones Jurídicas de la UNAM

que también está controlada por normas. Es un sistema que reclama autoridad vinculante sobre los miembros del Estado en un territorio y que puede emplear la coacción física legítima para el mantenimiento del statu quo.

El concepto de Estado weberiano, según Ignacio Sotelo, tendría un doble parentesco: con Hegel porque se sublima la violencia existente en la etapa de prevalencia de la sociedad civil, ${ }^{37}$ y con Marx, porque se reconoce que es un instrumento de la violencia de la clase dominante. ${ }^{38}$ No obstante, para Weber, las formas pre-estatales compartieron con otras instancias el empleo legítimo de la fuerza - en el Feudalismo claramente con la Iglesia-; en cambio en el Estado moderno no. El Estado moderno no deja espacio social para el uso de la violencia. Fuera del Estado cualquier violencia es ilegítima; sólo es legítima la violencia que emplea el Estado bajo determinadas condiciones formales y regladas.

\section{LAS TEORÍAS DEL ESTADO MODERNO DE CARÁGTER ABSOLUTO}

El Estado del Renacimiento y los posteriores, durante el absolutismo, se irán caracterizando durante los siglos XVI y XVII por concentrar el poder en el monarca absoluto. Éste patrimonializa y personifica la autoridad política al máximo. El monarca es el supremo poder temporal dentro de los reinos, en el que no reconoce superior alguno. El rey es la fuente de la legislación y la jurisdicción; decide sobre la guerra y la paz, dirige el ejército y la administración. Se puede decir que en él reside la soberanía. ${ }^{39}$ En el Estado absoluto no existe un catálogo de derechos ni un principio de división de poderes ni

37 Con Hegel el Estado es consecuencia de la evolución de la familia y de la sociedad civil. En la familia encontramos la vinculación de lo subjetivo con lo objetivo y es la primera de las formas de articulación y de organización social. La sociedad civil implica tres momentos: la mediación de la necesidad y la satisfacción del individuo con su trabajo, como la satisfacción de las necesidades de todos los demás; la defensa de la propiedad privada mediante la administración de justicia, y la prevención de la accidentalidad a través de la policía y la corporación. La sociedad civil es imperfecta, llena de contradicciones y es el ámbito de la necesidad y de la búsqueda egoísta de ganancias. En el Estado se establecen las condiciones de equidad pues es el espacio de la racionalidad. El Estado es la expresión de la idea absoluta, de la perfección, en él quedan garantizadas las libertades y los derechos a través de la Constitución que se orienta hacia la búsqueda del interés general. Hegel, Guillermo Federico, Filosofia del derecho, México, 1986, pp. 175 y ss.

38 Sotelo, Ignacio, "Estado moderno", en Díaz, Elías y Ruiz Miguel, Alfonso Filosofía política II. Teoría del Estado, Madrid, Editorial Trotta, 1996, p. 35.

39 Gabriel, José Antonio de, "La formación del Estado moderno", en Águila, Rafael del, Manual de Ciencia Politica, op. cit., p. 43. 
Este libro forma parte del acervo de la Biblioteca Jurídica Virtual del Instituto de Investigaciones Jurídicas de la UNAM

tampoco podemos hablar de un principio de legalidad o de medios de control de constitucionalidad, y mucho menos, de principios democráticos. Generalmente, la legitimidad del poder se fundamenta en el derecho divino de los reyes o en el origen dinástico de las familias reales. El derecho de resistencia o de desobediencia de los súbditos al monarca, es teórica y jurídicamente reducido al mínimo. El monarca controla el ejército o los ejércitos, y ejerce un poder directo sobre los súbditos a través del sistema impositivo, jurisdiccional, burocrático y jurídico. La Iglesia queda subordinada al monarca al igual que los antiguos señores feudales. Se desarrolla la burguesía como clase social emergente y nuevos modos de producción de carácter capitalista aparecen, fundamentalmente, mercantilistas. Todos los recursos humanos, materiales, financieros, burocráticos, militares y espirituales, se ponen al servicio del monarca, lo que proporciona al Estado moderno absolutista un poder inmenso, capaz de imponerse a cualquier otra instancia de poder de la época. Sólo entre Estados - entre monarcas - era concebible la rivalidad en plano de igualdad, pues al interior de cada Estado, todo y todos, están subordinados al poder del Estado, es decir, del monarca.

Se dice que en el campo jurídico-político, el Estado absolutista es la primera manifestación del territorium clausum, dentro del cual el monarca posee el monopolio de la violencia. Dicho monopolio se pone al servicio del derecho y la jurisdicción administrados a nombre del rey. En el Estado absoluto, el monarca al ser soberano, está por encima del derecho que crea. El monarca absoluto es legibus solutus, no debe rendir cuentas a nadie de sus actos - sólo a Dios- Aún en las etapas finales del Estado absoluto, en la época del despotismo ilustrado, se señalaba: "todo para el pueblo, pero sin el pueblo". ${ }^{40}$

Benz caracteriza al Estado absoluto, en su proceso de centralización y concentración del poder, con las siguientes notas:

1) Es un Estado que desarrolla el monopolio del poder y asocia a éste la idea de soberanía, con lo que el Estado pasa a convertirse en el único poder supremo de la sociedad; sólo al Estado le corresponde el derecho de citar y hacer ejecutar las leyes, extraer impuestos y mantener relaciones de cooperación o de guerra con otros Estados.

2) La concentración de poder en el príncipe implica el establecimiento de un ejército y el control sobre él, un cuerpo administrativo burocrático a su servicio que recabe impuestos de los súbditos, y un po-

40 Cotarelo, Ramón, “Teoría del Estado”, en Díaz, Elías y Ruiz Miguel, Alfonso, Filosofía política II. Teoría del Estado, Madrid, Trotta, 1996, p. 19. 
Este libro forma parte del acervo de la Biblioteca Jurídica Virtual del Instituto de Investigaciones Jurídicas de la UNAM

der judicial que depende del príncipe y dicta sus resoluciones en su nombre.

3) El Estado absolutista se convierte en la instancia de control de los procesos económicos, pues asume tareas de aprovisionamiento de la economía - mercantilismo - y afronta ciertos problemas sociales, como la regulación asistencial a favor de los pobres.

4) En el Estado absoluto todas las provincias, regiones y ciudades están sometidas al Estado central y a sus representantes y funcionarios centrales.

5) A partir de la Guerra de los Treinta Años (1648) se forma un sistema internacional de Estados consistente en la igualdad entre ellos, que se afirma mediante una política de poder (las únicas posibilidades entre Estados eran el conflicto por medio de la guerra o la cooperación a través del tratado), y teóricamente, se construye una concepción de la soberanía exterior. De esta suerte la soberanía presenta dos caras: al interior, nadie por encima del Estado, y al exterior, igualdad entre los Estados, sin que ninguno intervenga en las decisiones internas del otro. ${ }^{41}$

El modelo económico del Estado absoluto fue el mercantilismo, que constituye, no tanto una práctica coherente, sino una serie de creencias, de teorías y prácticas sobre la economía en un periodo que comprende de 1450 a 1750; es decir, de la economía medieval a la fisiocracia. Como doctrina económica sufrió transformaciones que se manifestaron de diferente forma según el Estado en donde se realizaba. Existe la opinión errónea de que el mercantilismo fue antiliberal; lo que es totalmente falso, como lo prueba el ejemplo de Holanda que practicó un mercantilismo a todas luces liberal. La razón del liberalismo en el mercantilismo está en la importancia que en esta doctrina tiene el comercio. Se puede decir que el alma del mercantilismo es el comercio y éste no puede desarrollarse sin libertad económica. Otro elemento fundamental del mercantilismo es la propiedad inmobiliaria que necesariamente exige de la libertad económica para promoverse. René Gonnard sintetiza las características del mercantilismo:

1) El mercantilismo se basa en la creencia de que el Estado debe perseguir la adquisición de oro y plata para su enriquecimiento y promoción de la actividad económica.

2) La conquista de los metales preciosos debe ponerse en manos del Estado a través de ordenanzas y edictos reales.

41 Benz, Arthur, El Estado moderno. Fundamentos..., op. cit., pp. 40 y 41. 
Este libro forma parte del acervo de la Biblioteca Jurídica Virtual del Instituto de Investigaciones Jurídicas de la UNAM

3) El mercantilismo promueve la explotación minera, evita la salida del metal y favorece la entrada del mismo a los territorios del Estado.

4) El Estado debe organizar la industria y el comercio. La industria a través de medidas poblacionistas, máximo legal de salarios, régimen de trabajo forzoso, creación de manufacturas reales, estímulos a los capitalistas, subvenciones, protecciones, recompensas honoríficas a los directores de las industrias. Para el comercio, debe favorecer las exportaciones por encima de las importaciones, crear mercados para los productos nacionales, colonizar países nuevos e imponer, mediante la hegemonía, condiciones de comercio desfavorables a los países más débiles.

5) El mercantilismo asume el principio de que las pérdidas o las ganancias en el Estado nacional dependen de las pérdidas o ganancias de otros Estados nacionales. Como puede advertirse los elementos más importantes de esta doctrina económica están en la búsqueda y mantenimiento del oro en las arcas del Estado absoluto y en la hostilidad para las demás naciones en los intercambios de comercio. ${ }^{42}$

Esta realidad económica y política novedosa que implicaba una enorme concentración de poder en los monarcas europeos, prohijó una teoría política del Estado que se intentó explicar por los filósofos, políticos y juristas de la época. La reflexión teórica sobre el Estado moderno de carácter absoluto tiene tres representantes fundamentales: Maquiavelo, Bodino y Hobbes. Maquiavelo, además de haber empleado por primera vez la expresión Stato y de haber promovido el divorcio entre la política y la ética que llamamos hoy en día de la convicción, es el justificador de la organización de las monarquías nacionales absolutas, así como de las formas modernas del nuevo Estado ancladas en la realidad y que facilitarán el desarrollo posterior del capitalismo en sus modos contemporáneos. Así, Maquiavelo es partidario de la organización de instrumentos específicos para unificar el poder en el Príncipe. ${ }^{43}$ Entre esos instrumentos están: la existencia de un ejército nacional y de una hacienda pública propia y diferenciada de las finanzas de los señores feudales. La idea del Estado de Maquiavelo implica desprender de él a la sociedad, el poder es un elemento puro y la tarea de la ciencia política es preguntarnos por las técnicas para alcanzarlo, conservarlo y ampliarlo. La reflexión sobre el poder, así como la religión, los ejércitos o la hacienda pública, y todo, absolutamente todo, debe quedar subordinado a los fines del Estado. Como se

42 Gonnard, René, Historia de las doctrinas económicas, Madrid, Aguilar, 1961, pp. 43-166.
43 Maquiavelo, Nicolás, El príncipe, Madrid, Alianza Editorial, 1988, pp. 63 y ss. 
Este libro forma parte del acervo de la Biblioteca Jurídica Virtual del Instituto de Investigaciones Jurídicas de la UNAM

sabe, la razón de Estado es una teoría renacentista que surge con las obras de Maquiavelo y de Guicciardini que expone que el interés del Estado está por encima de los derechos humanos individuales y colectivos si con ello se obtiene la fortaleza del Estado y del príncipe. Hoy en día nos preguntamos si toda razón de Estado está justificada, por ejemplo, si estaría permitida la masacre de seres humanos en aras de lograr el engrandecimiento de las instituciones, pues siempre es importante preguntarse si existen otros métodos legales y legítimos que permitan alcanzar esos fines sin que se produzca una afectación en los derechos. La razón de Estado, de aceptarse en términos contemporáneos, tendría que ser siempre legítima y proporcional. ${ }^{44}$

Las técnicas de gobierno, el cómo conseguir el éxito, y cómo obtener el orden y la estabilidad política, son la clave de la obra de Maquiavelo y los fines del Estado que propugna. Las técnicas del gobierno se obtienen de máximas o reglas obtenidas de la historia y de la experiencia, con intención de que sean útiles al gobernante. Las técnicas se obtienen inductivamente y no se deducen de la moral cristiana sino que se alcanzan a través del estudio de la política del pasado y de la observación del presente. Las técnicas son realistas y no moralizadoras. En cuanto al éxito, Maquiavelo entiende que éste deriva del adecuado y competente uso del poder. Por ello, es imperioso conocer la habilidad, la inteligencia, el coraje, la flexibilidad del gobernante para adaptarse a las circunstancias, aún a las más adversas. La virtú en Maquiavelo entraña una capacidad para gobernar que siempre está acechada por los caprichos de la fortuna (los cambios y accidentes imprevisibles). ${ }^{45} \mathrm{El}$ príncipe está obligado a dominar el entorno para tomar las riendas de la historia. Finalmente, el orden y la estabilidad de un gobierno, dependerá de la virtú del gobernante pero también del conocimiento y aplicación de la razón de Estado; es decir, de motivos, objetivos y reglas que trascienden a los individuos y a las colectividades pero que empleados eficaz y eficientemente por el gobernante mantienen la gobernabilidad del Estado.

No obstante, antes de lograr lo anterior, lo primero que debe realizar el príncipe es lograr la unidad nacional, principio básico de la construcción maquiavélica del Estado. Si la unidad nacional no existe, el Estado debe proponer lograrla, acabando con los poderes de la Iglesia, expulsando a los

44 Para Maquiavelo, el criterio para distinguir la buena política de la mala no es al que aquí me refiero - la moralidad de los medios y fines - En Maquiavelo sólo el éxito del príncipe, que se mide por su capacidad de conservar, ampliar y proteger el Estado, por el medio que sea es el criterio para concluir si es buena o acertada su política. Bobbio, Norberto, $L a$ teoría de las formas de gobierno en la historia del pensamiento político, México, Fondo de Cultura Económica, 2014, p. 71.

45 Maquiavelo, Nicolás, op. cit., pp. 116 y ss. 
Este libro forma parte del acervo de la Biblioteca Jurídica Virtual del Instituto de Investigaciones Jurídicas de la UNAM

extranjeros y unificando en un solo mando los reinos, repúblicas y ciudades de la nación. ${ }^{46} \mathrm{El}$ príncipe de una república, ${ }^{47}$ región o ciudad, es la variable fundamental para ello, si cuenta con el suficiente poder económico y militar para transformarse de un dirigente en el creador del Estado.

Como algunos han dicho, el objetivo inmanente a la acción política en Maquiavelo siempre es la estabilización de un poder estatal centralizado, cuya existencia es la condición para el bienestar general de los ciudadanos. Maquiavelo es un defensor de la incipiente sociedad burguesa, que precisa de un fuerte poder central para posibilitar la libertad de movimientos al comercio, a la industria y al intercambio económico. Desde el marxismo se ha dicho con razón, que la teoría maquiavélica y otras posteriores, aún las de los contractualistas liberales, son concepciones que no consideran que el poder de las clases burguesas es devenido históricamente sino que se estima como eterno. ${ }^{48}$

De manera muy clara a partir de Hegel, pero sobre todo con Marx, se entiende que el poder de cualquier clase dominante es histórico y transitorio y puede ser sustituido por el poder de otras clases. Sin embargo, Maquiavelo consideraba que los conflictos - tumultos - no son la causa de la ruina de los Estados sino la condición para que se promulguen buenas leyes en defensa de la libertad. Podemos decir que la duración en el acatamiento de los súbditos al poder central y unificador que realiza el Príncipe dependerá de cómo los involucrados - el príncipe y los súbditos o ciudadanos - asuman o no el carácter transitorio del poder y la dominación, y de cómo se dé respuesta al conflicto entre partes contrapuestas. ${ }^{49}$

En la obra de Bodino se identifica a la soberanía con la suprema autoridad, se trata de un poder absoluto ${ }^{50}$ y perpetuo ${ }^{51}$ de la República, lo que los latinos llamaron majestad, y que en Bodino, define al Estado. Según Bo-

\footnotetext{
46 Ibidem, pp. 120 y ss.
}

47 En los discursos sobre la primera década de Tito Livio, Maquiavelo hace una argumentación totalmente favorable a las repúblicas sobre otras formas de gobierno. Maquiavelo, Nicolás, Discursos sobre la primera década de Tito Livio, Madrid, Alianza Editorial, 1987.

48 Lenk, Kurt, "La ciencia política como crítica e instrumento de poder — visión histórico-dogmática-", en Abendroth, Wolfgang y Lenk, Kurt, Introducción a la ciencia política, Barcelona, Anagrama, 1971, pp. 29-58.

49 Bobbio, Norberto, La teoría de las formas de gobierno en la historia del pensamiento político, op. cit., pp. 78-79.

50 Por absoluto se entiende que el poder soberano debe ser legibus solutus, es decir, debe estar desligado de la obligación de obedecer las leyes dadas por sus predecesores y las que él produjo en tiempo anterior. Bodino, Juan, Los seis libros de la república, Madrid, Aguilar, 1973, p. 359.

51 Porque se otorga al monarca de por vida y no por un periodo determinado. 
Este libro forma parte del acervo de la Biblioteca Jurídica Virtual del Instituto de Investigaciones Jurídicas de la UNAM

dino la soberanía en estado puro sólo puede darse en la monarquía porque el poder para ser absoluto también debe ser indivisible. ${ }^{52}$ Sin embargo, la soberanía nunca constituye un poder ilimitado, arbitrario o caprichoso porque el soberano estaba limitado por las leyes naturales y comunes a todos los pueblos. Las autoridades, especialmente el legislador, tienen límites que no pueden romper y son, para Bodino, el derecho de gentes y la igualdad jurídica de los Estados. ${ }^{53}$ Bodino es, por tanto, no sólo el máximo exponente de la teoría de la soberanía, sino que también es un autor seminal, aunque bastante ambiguo, sobre el control del poder. ${ }^{54}$ Para algunos su obra es un antecedente del concepto Estado de derecho burgués. Lo anterior quiere decir, que a Bodino además de interesarle el poder le preocupa que ese poder sea legítimo para que los súbditos - para la burguesía fundamentalmente - obedezcan la autoridad del soberano. ${ }^{55}$

Las razones del pensamiento de Bodino devienen de su intención y de su tiempo. Él no trata de crear un Estado como Maquiavelo (dado que Italia estaba fragmentada y sus repúblicas y reinos estaban en permanente conflicto interior y exterior) sino de darle estabilidad a su país. En la época de Bodino, Francia se encontraba convulsionada por las guerras de religión entre protestantes y católicos. Para este autor la intransigencia religiosa era la causa de la inestabilidad de la nación; por eso, era necesario encontrar una fórmula constitucional para el consenso. Esa fórmula es la soberanía, la que se ejerce contra los enemigos interiores y exteriores y consiste en la capacidad para elaborar leyes generales. El monarca, según Bodino, debía defender la propiedad y la familia de los súbditos y asumir la guerra que tuviese fines defensivos. Su postura favorecía un mandato fuerte, pero con libertad para que algunos miembros de la sociedad hicieran dinero y gozasen de una seguridad razonable. El Estado soberano de Bodino está al servicio

52 Dice Paoli Bolio que la razón de la indivisibilidad del poder es que si éste se divide deja de ser eficaz. El Estado que se organiza de manera mixta, dando atribuciones a distintos cuerpos, que es lo que proponían Aristóteles, Polibio, Cicerón o Maquiavelo, tendrá siempre conflictos que reducirán su eficacia y la seguridad que se puede ofrecer a la comunidad de que se mantendrá unida. La mixtura es la causa de la inestabilidad. En un Estado la soberanía sólo puede tener un titular y para Bodino es el monarca, no un grupo o el pueblo. Paoli Bolio, Francisco José, Teoría del Estado, México, Trillas, 2009, pp. 86 y 87.

53 Bodino, Juan, Los seis libros de la república, op. cit., capítulo primero, pp. 47-73.

54 Bodino distingue entre monarquía real, tiránica y despótica. La real es la que respeta las leyes de la naturaleza, la tiránica es la que no las respeta, y la despótica es la que se deriva de la guerra santa y justa al ser vencidos los nuevos súbditos por el monarca. Bodino, Juan, Los seis libros de la República, Madrid, Aguilar, 1973, pp. 572, 594 y 595.

55 Sabine, George H., Historia de la Teoría Política, México, Fondo de Cultura Económica, 1988, p. 303. 
Este libro forma parte del acervo de la Biblioteca Jurídica Virtual del Instituto de Investigaciones Jurídicas de la UNAM

de la burguesía, y como dice Bobbio, la distinción entre la sociedad de los privados, regulada por el derecho privado, que es un derecho entre iguales, y la sociedad política, regulada por el derecho público, es decir, un derecho entre desiguales que acompaña la formación del Estado moderno, y agrega Bobbio, no es una invención de Hegel. 56

La obra de Bodino permite al menos dos lecturas. Con una primera interpretación, entendemos que Bodino es el justificador del poder hegemónico de los monarcas absolutos y sentó las bases para un comportamiento absolutista e irresistible de los reyes - sin posibilidad de derecho de resistencia o de crítica-. En una segunda interpretación, observamos que Bodino esboza los rasgos característicos del Estado como persona jurídica, como institución que tiene una personalidad distinta, superior y permanente, más allá de las personas o grupos que integran a la sociedad. Jurídicamente Bodino expuso los atributos de la soberanía, especificando los derechos del soberano: dar y anular las leyes, interpretar y enmendar las leyes, declarar la guerra y negociar la paz, designar a los principales gobernantes, ostentar la jurisdicción suprema, conceder gracia a los condenados, acuñar moneda y establecer pesos, medidas y tributos..$^{57}$

Es indudable que la conceptualización jurídica de la soberanía de Bodino sirve para imputar a un ente abstracto que es el Estado de actos jurídicos como si fuese una persona, tanto en sus relaciones internas y externas - es una ficción jurídica institucional que perdura aunque el monarca desaparezca- - Sin embargo, la soberanía también entraña que el Estado no tiene ningún poder superior a él de tipo jurídico, político o social, y que esa supremacía no admite fisuras, divisiones ni términos temporales. El súbdito debe obedecer al poder soberano si éste protege su vida y sus bienes; la obligación política se reduce a esos términos y las posibilidades de desobediencia en los hechos son remotas. La soberanía implica un atributo del Estado intemporal que no se construyó pensando en el conflicto entre las clases sociales sino como un poderoso instrumento para mantener el status quo de los intereses de la burguesía y de la aristocracia amparados por el manto del Estado absoluto.

Bodino es un defensor a ultranza de la propiedad privada a la que considera inviolable, y en materia de impuestos, sostiene que éstos requieren del consentimiento de los súbditos. Podríamos decir que en realidad, la sobera-

56 Bobbio, Norberto, La teoría de las formas de gobierno en la historia del pensamiento político, México, Fondo de Cultura Económica, 2014, p. 82.

57 González Casanova, José Antonio, Teoría del Estado y derecho constitucional, Barcelona, Ediciones Vicens-Vives, 1989, pp. 89-94. 
Este libro forma parte del acervo de la Biblioteca Jurídica Virtual del Instituto de Investigaciones Jurídicas de la UNAM

nía tiene dos límites: las contribuciones que el Estado no puede imponer a los súbditos sin su consentimiento, y las leges imperii - como la facultad de dictar las leyes - que el soberano no puede derogar en su perjuicio porque son el marco en el que éste ejerce la soberanía y son inherentes a ella. Sin embargo, como lo han advertido muchos estudiosos, en caso de que el soberano fuera en contra de esas condiciones que han sido establecidas a favor de la burguesía, no queda claro hasta dónde Bodino justificaría la desobediencia y la resistencia al Estado. ${ }^{58}$

La teoría de Hobbes acogió la metáfora antropomórfica del Estado. De la visión del Estado soberano como persona surge lo que hoy llamamos el positivismo jurídico: los principios de legalidad y de autonomía de la voluntad, la validez formal del derecho, el principio del monopolio del Estado en la producción del derecho, la unidad del ordenamiento y su independencia de las fuentes jurídicas extra o supra estatales. En el ámbito externo, según la teoría de Hobbes, los Estados se encuentran entre sí en la condición del estado de naturaleza. ${ }^{59}$ Sólo al interior del Estado se tienen posibilidades de disciplinar al poder.

¿Por qué el Estado logra esa posibilidad? Porque los seres humanos en estado de naturaleza no aspiran más que a la acumulación infinita de poder. La solución es concentrar todos esos poderes individuales en el Estado. El Estado surge como la vía para acabar con las guerras al centrar en el monarca las decisiones sobre los litigios particulares. La pluralidad individual y social del estado de naturaleza desemboca en querellas y luchas, y al final, en caos. El Estado brinda, por el contrario, unicidad y orden; es el garante de la paz interna, aunque no necesariamente de la paz externa, porque las relaciones entre Estados reproducen las condiciones de "guerra de todos contra todos". Se requería a nivel externo de un árbitro mundial que hiciese las veces del Estado-nación en el nivel interno.

El leviatán de Hobbes es un artificio para explicar la conveniencia de un Estado fuerte que ofrece la mayor seguridad. ${ }^{60}$ Por eso, Hobbes prefiere la monarquía absoluta, aunque ello no le impidió someterse a la eficacia de la república de Cromwell. Hobbes no admite ningún límite al ejercicio de la soberanía para garantizar la seguridad y con ello el bienestar de los indi-

58 Sabine, George H., Historia de la Teoría Política, México, Fondo de Cultura Económica, 1988, p. 305.

59 Hobbes, Thomas, Leviatán o la materia, forma y poder de una República eclesiástica y civil, México, Fondo de Cultura Económica, 2014, capítulo 18, p. 147.

60 Hobbes, Thomas, Leviatán o la materia, forma y poder de una República eclesiástica y civil, op. cit., capítulo 17, p. 137. 
Este libro forma parte del acervo de la Biblioteca Jurídica Virtual del Instituto de Investigaciones Jurídicas de la UNAM

viduos. Históricamente la etapa de la monarquía absoluta también implicó la consolidación progresiva de la propiedad privada absoluta. ${ }^{61}$ Hobbes no pretendió explicar empíricamente el nacimiento del Estado, sólo quiso afirmar la necesidad de un poder político absoluto que debía justificarse a partir del propio Estado como garante de la seguridad. ${ }^{62}$

El contrato de Estado sella la identificación entre la voluntad del Estado con la del soberano. ${ }^{63}$ Una vez acordado el Estado por los ciudadanos, éste es irrevocable, ${ }^{64}$ aunque los soberanos sean responsables ante Dios y la razón humana del cumplimiento del contrato. No obstante, los ciudadanos no pueden obligar por sí mismos al soberano a que cumpla con sus obligaciones; el poder público carece de control y por eso Bobbio sostiene que Hobbes no aceptaba la teoría de la separación de poderes. ${ }^{65}$ El poder del Estado sólo logra mantenerse si es absoluto ${ }^{66}$ y el orden existente en él es justo porque únicamente su existencia excluye la anarquía y el estado de naturaleza. ${ }^{67}$ De esta suerte, se niega todo derecho de resistencia contra los poderes públicos porque la resistencia amenazaría el fin del Estado que es la conservación de la paz.

En la teoría hobbesiana es muy importante señalar que el soberano se encuentra por encima de la ley y es la fuente de la misma. El Estado ejerce el mando de las fuerzas armadas, tiene poder sobre toda la propiedad y controla la opinión pública, ya que sin estas características, sus poderes no

61 Anderson, Perry, El Estado absolutista, Madrid, Siglo XXI, 1979, p. 441.

62 Heller, Hermann, Teoría del Estado, op. cit., pp. 38 y 39.

63 El contrato está integrado por tres pactos: el pactum unionis como fruto de la decisión de vivir en común; el pactum ordinationis o acuerdo sobre la organización institucional del Estado, y el pactum subiectionis que es el acuerdo sobre el respeto y sometimiento al poder y a las leyes del Estado. Sobre estos pactos véase Alba Rico, Santiago, "Clima, cuerpo y política”, en Iglesias, Pablo (coord.), Ganar o morir. Lecciones políticas en juego de tronos, Madrid, Akal, 2014, pp. 259-260.

64 Hobbes, Thomas, Leviatán o la materia, forma y poder de una República eclesiástica y civil, op. cit., capítulo 21, p. 180. Sin embargo, dice Hobbes: "La obligación de los súbditos con respecto al soberano se comprende que no ha de durar ni más ni menos que lo que dure el poder mediante el cual tiene capacidad para protegerlos".

65 Bobbio, Norberto, La teoría de las formas de gobierno en la historia del pensamiento político, op. cit., p. 104.

66 Hobbes, Thomas, Leviatán o la materia, forma y poder de una República eclesiástica y civil, op. cit., capítulo 20, p. 169.

67 Lenk, Kurt, "La ciencia política como crítica e instrumento de poder — visión histórico-dogmática—”, op. cit., p. 38. 
Este libro forma parte del acervo de la Biblioteca Jurídica Virtual del Instituto de Investigaciones Jurídicas de la UNAM

serían supremos, y si eso ocurriera, el contrato ya no sería obligado, y se tendría que volver en consecuencia al estado de naturaleza previa. ${ }^{68}$

Muchos años después de Hobbes pero igual que él, Carl Schmitt, sostuvo una posición a favor del Estado absoluto y fascista cuando señalaba que el Estado sólo lo es, si relativiza todos los status y consigue convertirse en un arma única y plena contra la guerra civil. Según Schmitt el Estado tenía que acentuar su elemento político, su poder, tal como había venido haciendo desde el siglo XVII, y debía pacificar el conflicto interviniendo directa y claramente, no relativizándolo, es decir, optando por una de las alternativas en juego y no varias a la vez. El leviatán tiene como principal deber lograr la obediencia de los súbditos y la supresión frente a sus mandatos de todo derecho de resistencia. ${ }^{69}$

\section{LA TRANSFORMACIÓN DEL ESTADO ABSOLUTO HACIA EL ESTADO LIBERAL}

En los hechos el Estado absoluto nunca fue tan absoluto. La centralización y concentración de poder a la que se aspiraba no se logró del todo, sobre todo en algunos países como Holanda o Inglaterra. Lo anterior se debió principalmente a la existencia de la correlación variable de fuerzas existente entre el monarca, la aristocracia y la incipiente burguesía; además que en muy pocos casos, el monarca tuvo acceso a la totalidad de los recursos a los que aludía la doctrina económica mercantilista.

En muchas situaciones los príncipes tuvieron que tener en cuenta a los estamentos y a la Iglesia. La facultad legislativa del príncipe le impedía legislar contra las normas derivadas de la fe cristiana o en contra de lo que se consideraba derecho natural. En materia de impuestos, por ejemplo, salvo en Francia en el periodo de 1614 a 1789, las asambleas estamentales tenían que aceptar las contribuciones que determinaban los príncipes. Si no existía la conformidad de las asambleas, como demuestra el caso francés, las insatisfacciones y protestas de campesinos y ciudadanos se incrementaban.

Las constantes guerras de los monarcas absolutos y los niveles de endeudamiento que éstas generaban, fueron socavando la autoridad regia. Además, en el Estado absoluto los cargos públicos se vendían, lo que propicia-

68 Croosman, R. H. S., Biografia del Estado moderno, México, Breviarios del Fondo de Cultura Económica, 1974, pp. 76 y 77.

69 Schmitt, Carl, El valor del Estado y el significado del individuo, Madrid, Centro de Estudios Políticos y Constitucionales, 2011, p. 58. 
Este libro forma parte del acervo de la Biblioteca Jurídica Virtual del Instituto de Investigaciones Jurídicas de la UNAM

ba corrupción, ineficiencia e ineficacia en la administración pública, sobre todo en la administración de las finanzas. Los adquirentes de esos cargos no los ocupaban para satisfacer el interés general o colectivo sino para maximizar sus recursos y patrimonio. Un buen número de quejas comenzaron a aparecer en el siglo XVII, principalmente en contra de los asentamientos de población, la falta de uniformidad en los salarios, la impotencia en contra del contrabando, etcétera. ${ }^{70}$

Hermann Heller dice que el absolutismo, por medio de la política mercantilista, convirtió al Estado en el más fuerte sujeto económico capitalista, pero al mismo tiempo, descuidó el capital agrario que se encontraba en manos de los viejos señores, lo que permitiría el desarrollo de otras doctrinas económicas que se manifestarían más tarde como la fisiocracia y el entendimiento del derecho de propiedad como un derecho previo al Estado que no se cede al soberano, y además, sin quererlo plenamente, el mercantilismo alentó con sus regulaciones estatales el nacimiento del poder económico de la burguesía en los ámbitos financieros, comerciales e industriales, lo que iría motivando exigencias de mayor libertad económica y garantía de derechos de la burguesía naciente frente al monarca. ${ }^{71}$

El pensamiento fisiócrata que se consolidaría hasta el siglo XVIII, pero que se fue desarrollando lentamente durante el siglo XVII, constituía un ataque frontal al mercantilismo y al Estado absoluto por las siguientes razones: 1) promovía las exportaciones agrícolas sobre las demás; 2) opinaba que más que exportar gran cantidad de productos agrícolas se debían exportar éstos a buen precio para no debilitar la posición de los propietarios nacionales ni la de los jornaleros; 3) daban más importancia al mercado interior que al exterior para promover el mercado y la economía interna; 4) promovían la industrialización interna, y 5) concebían el derecho de propiedad como un derecho previo al Estado que garantiza la libertad de las personas y que debía ser protegido por el monarca. Era evidente que con éste cúmulo de ideas, las clases propietarias de la tierra, los comerciantes y los nuevos industriales, exigirían del Estado absoluto más espacios de libertad y de poder para incrementar las dimensiones de sus negocios. ${ }^{72}$

De esta suerte, la economía se va convirtiendo en una nueva filosofía política. Como dice González Casanova, la sociedad empieza a ser concebida como un sistema de relaciones jurídico privadas de contenido eco-

70 Laski, Harold J., El liberalismo europeo, México, Fondo de Cultura Económica, 2012, pp. $76-138$.

71 Heller, Hermann, Teoría del Estado, op. cit., p. 180.

72 Gonnard, René, op. cit., pp. 204-208. 
Este libro forma parte del acervo de la Biblioteca Jurídica Virtual del Instituto de Investigaciones Jurídicas de la UNAM

nómico, y el papel del Estado es colaborar a que esta armonía natural de hombres libres y productores, relacionados por intereses egoístas complementarios, pueda desenvolverse en paz, protegida por el orden público. El Estado se halla al servicio de la sociedad, y en realidad, los Estados son partes alícuotas, de una sola sociedad universal. No hay razón para encerrarse en las fronteras del Estado y mucho menos guerrear, cuando la división del trabajo y la variedad de las tierras permite a todos enriquecerse. ${ }^{73}$

A este tipo de posiciones favorecieron esquemas filosóficos como el de Althusius, que formuló una concepción del orden político apoyado en un conjunto de estructuras estamentales y colectivas y en pequeñas unidades territoriales, como las ciudades. Su propuesta era que el orden político se compusiera de comunidades y corporaciones y no sólo de individuos. Sus puntos de vista son antecedente de las nociones del federalismo contemporáneo, en cuanto a que el poder debía construirse de abajo hacia arriba. Claramente el punto de vista de Althusius era alternativo al esquema de dominación basado en un Estado absoluto y centralizado. ${ }^{74}$

Por otra parte, el absolutismo no se impuso por igual en todas partes. Como dice Benz, en Inglaterra, Suecia o Polonia, apenas puede hablarse de una corta fase de absolutismo, mientras que en Francia se mantuvo dos siglos y consiguió un desarrollo total. En Francia, el ejercicio práctico del poder por funcionarios ad hoc generó constantes arbitrariedades, pues tanto el rey como los titulares de los cargos comprados perseguían intereses personales y no estaban limitados por ninguna instancia de control, lo que desde luego, hacía nacer profundas inconformidades y rechazos. ${ }^{75}$

Otro impacto que recibió el absolutismo fue la reforma protestante. Ésta alentó tres variables fundamentales que explican por qué horadó a la realidad del Estado absoluto. Éstas son: 1) el individualismo, en cuanto cada persona tiene una relación personal con Dios, puede comunicarse directamente con él, sin necesidad de intermediarios; 2) la tolerancia, que aunque tardíamente fue asentándose relativizaba el poder de las iglesias y del propio monarca; no existía una verdad ni una fe única que pudiera demandar exclusividad, y 3) la ética calvinista que propiciaba valores como el individualismo, la austeridad, el ahorro y la disciplina social, que serían los principios animadores de la futura moral burguesa compatible con el capitalismo. $^{76}$

\footnotetext{
73 González Casanova, José Antonio, op. cit., p. 104.

74 Benz, Arthur, op. cit., p. 46.

75 Ibidem, p. 43.

76 LaskiI, Harold J., op. cit., pp. 31 y ss.
} 
Este libro forma parte del acervo de la Biblioteca Jurídica Virtual del Instituto de Investigaciones Jurídicas de la UNAM

Una consecuencia muy importante de la reforma, fue el cuestionamiento al origen divino de los monarcas. Según la concepción protestante, la religión se convirtió en una cuestión de comportamiento individual, de libre decisión personal, y no de mandatos y prohibiciones de la Iglesia. Aunque pareciera que el golpe era fundamentalmente contra el Papa, como de hecho lo fue, también lo recibió el Estado absoluto, porque doctrinas como la de Martín Lutero sobre los dos reinos, respondían al postulado de reducir la influencia de la Iglesia en los asuntos seculares. Era, por tanto, necesario acudir a otras fuentes de legitimidad y de fundamento del poder que ya no podían ser divinas, sino basarse, como lo veremos más adelante con Locke, en el consentimiento de los gobernados.

Las necesidades derivadas de la exploración y conquista del nuevo mundo desarrollaron el espíritu científico complementado con el avance tecnológico, y también, fueron causa paulatina de la crisis del Estado absoluto. Aparecieron nuevos instrumentos derivados de la geografía, navegación, astronomía, medicina y desarrollo de obras públicas, que ponían en cuestión las antiguas visiones teológicas y despertaban en las personas un sentimiento utilitario de la vida. La teoría del progreso y la fe racionalista eran consecuencia de esos cambios y compaginaban muy bien con las nuevas ideas que se producían en la filosofía y con los propios intereses de la burguesía que reclamaba derechos y libertad.

La Ilustración, que va gestándose desde el siglo XVI pero que se consolida en el siglo XVIII y que tiene una impronta profundamente iusnaturalista, será junto al liberalismo económico el principal fundamento teórico y filosófico del Estado que se conformaría a finales del siglo XVIII, que pervivió durante el siglo XIX, y que hoy llamamos Estado liberal. Los principios fundamentales del iusnaturalismo son: 1) la autoridad política no se origina en la divinidad sino en la decisión humana y se expresa a través de un contrato; 2) la meta de toda organización política es de carácter secular y viene definida por los intereses individuales de los ciudadanos, y 3 ) la persona, por su mera existencia y como resultado de su íntima dignidad, es el sujeto de unos derechos humanos que deben ser respetados por el Estado. ${ }^{77}$ Este iusnaturalismo sirvió para defender posturas muy variadas: algunos exigieron que el monarca respetara los principios de la razón, que es lo que ahora conocemos como absolutismo ilustrado o despotismo ilustrado; otros reclamaron que los derechos humanos eran inalienables para luchar contra la arbitrariedad despótica; unos más hacían hincapié en el carácter universal

77 Kühnl, Reinhard, Liberalismo y fascismo: dos formas de dominio burgués, Barcelona, Fontanella, 1978, pp. 56-76. 
Este libro forma parte del acervo de la Biblioteca Jurídica Virtual del Instituto de Investigaciones Jurídicas de la UNAM

de los derechos para obligar al monarca absoluto a que los respetara y los aplicara él mismo, y finalmente, otro grupo proponía abiertamente la desobediencia y la resistencia en contra de las determinaciones arbitrarias del monarca.

Así, el Estado liberal que sustituye lentamente al Estado absoluto es la abstracción teórica y la materialización fáctica de factores que se producen en varios niveles y órdenes en el capitalismo, entre el siglo XVI y XIX. Económicamente a través de un proceso que va del mercantilismo pasando por concepciones fisiócratas hasta arribar a regímenes económicos de libre mercado, lo que permitió el incremento en la acumulación originaria del capital y fortaleció a la burguesía sobre el clero, la aristocracia y los propios monarcas. Ideológicamente, por medio de la Ilustración y el liberalismo que fueron socavando los fundamentados de legitimidad del Estado absoluto que fundaba el poder en la divinidad. Movimientos políticos y sociales como la Revolución Gloriosa de 1688 en Inglaterra, la Independencia de los Estados Unidos en 1776 y la Revolución francesa de 1789, que definieron un proyecto político para comprender al ser humano en un nuevo entorno económico, social y político, y que contribuyeron a delinear nuevos conceptos jurídicos como: los derechos humanos, la soberanía popular, la división de poderes, la república parlamentaria o presidencial, el principio de legalidad, etcétera.

Como veremos, el Estado liberal del siglo XIX fue un Estado burgués al servicio de esta clase para respaldar al modelo capitalista promovido por el liberalismo económico, e implicó una estructura de dominación basada en principios jurídicos precisos: imperio de la ley en donde ésta era según el discurso dominante, la expresión de la voluntad general; división de poderes para reducir, si lo había, el papel del monarca; principio de legalidad para que el gobernante no pudiera actuar con arbitrariedad en contra de los intereses económicos de la burguesía, y derechos humanos, concebidos jurídicamente para oponerse al poder despótico de los gobiernos. ${ }^{78}$

78 Díaz, Elías, Estado de derecho y sociedad democrática, Madrid, Edicusa, 1972, p. 29. 
Este libro forma parte del acervo de la Biblioteca Jurídica Virtual del Instituto de Investigaciones Jurídicas de la UNAM

\section{Capitulo Segundo}

\section{EL ESTADO LIBERAL DE DERECHO}

\section{LOS FUNDAMENTOS ECONÓMICOS DEL ESTADO LIBERAL DE DERECHO}

El desarrollo económico de finales del siglo XVIII y principios del siglo XIX exigía liberarse de los lastres del orden económico del absolutismo. En éste se imponía a los emprendedores una gran cantidad de límites a su actividad económica. La idea de la búsqueda de la riqueza como un fin valioso en sí mismo sólo se irá abriendo camino con el fin del modelo económico feudal. Los cambios económicos que produjeron el mercantilismo y la fisiocracia, exigían cada vez más, una economía dinámica cuya orientación de manera creciente fuera la producción de bienes y servicios sin barreras ni obstáculos promovidos por las instituciones y el orden jurídico. Era fundamental, por ejemplo, acabar con la obligación a la afiliación gremial, y también, era necesario ampliar todas las condiciones de libre cambio y del comercio. El Estado tenía que garantizar las bases de una sociedad de propietarios particulares autónomos mediante principios como los de autonomía privada, libertad del contrato, libertad de la propiedad y de herencia.

Cuando Adam Smith en La riqueza de las naciones de 1776,79 escribe sobre el principio de laisser faire, está protestando en contra de las limitaciones y obstáculos que el Estado absolutista determinaba en la vida económica de la época, por ejemplo, privilegios fiscales para algunos, organización gremial de la producción, aranceles y tarifas varias, restricciones a la venta de ciertos bienes o barreras al derecho a la libertad de la herencia, entre otros. Para Smith, el énfasis debía ponerse en la libertad económica y en la defensa del derecho de propiedad. La propiedad era una precondición para el ejercicio y materialización de otras libertades, tales como: la educación en la autonomía, la responsabilidad individual del propio destino, los

79 Smith, Adam, Investigación sobre la naturaleza y causas de la riqueza de las naciones, México, Fondo de Cultura Económica, 1958. 
Este libro forma parte del acervo de la Biblioteca Jurídica Virtual del Instituto de Investigaciones Jurídicas de la UNAM

hábitos de libre intercambio contractual, la confianza mutua, y en general, la universalización de la paz civil entre ciudadanos, todos ellos propietarios y libres.

El espacio para los intercambios entre los propietarios libres es el mercado. Éste es un punto de encuentro de los distintos intereses y voluntades individuales, que se armonizan libremente, sin necesidad de intervención del Estado. El mercado se regula automáticamente y hace que la persecución del propio interés devenga en bienestar general. Adam Smith y la economía política liberal posterior insistirá en la ausencia de interferencias del Estado para regular el mercado y la economía en general. En ese sentido debía existir total movilidad de los factores productivos, plena ocupación de los recursos y libertad del consumidor para preferir unos productos sobre otros. Bajo condiciones de competencia, sin monopolios, con un adecuado ajuste entre oferta y demanda, el bienestar general es una mera consecuencia.

Para Adam Smith, una nación vive satisfecha cuando hay abundancia de productos disponibles para distribuirse equitativamente entre las diferentes clases de la sociedad, abundancia que está condicionada a una creciente división del trabajo y a una ampliación permanente del mercado. Smith reconoció que para el progreso económico, además de la división del trabajo y de la ampliación constante del mercado, era necesario el uso correcto del capital, de la tierra y la valiosa cooperación del Estado en las actividades de los negociantes o empresarios. El papel del Estado consistía en garantizar la libertad económica, lo que significaba la abolición de las barreras aduaneras, monopolios y supresión de cualquier obstáculo legal que impidiese el libre cambio de productos. ${ }^{80}$

La obra de Adam Smith, pone el acento en una característica básica del Estado liberal de derecho: el abstencionismo. La misión del Estado se reduce a garantizar, sin intervenir, el libre desarrollo de las relaciones sociales y económicas privadas. Adam Smith concede al Estado tres funciones: a) acometer aquellas obras y servicios de interés público que no sean campo de empresas privadas; b) garantizar el orden público, y c) garantizar la defensa de la nación en contra de las agresiones exteriores. ${ }^{81}$ Tales son los deberes del Estado que el liberalismo acepta con carácter general. Cualesquier otra función es inaceptable para el Estado liberal de derecho.

80 Ferguson, John M., Historia de la economía, México, Fondo de Cultura Económica, 1974, pp. 59-76.

81 Smith, Adam, op. cit. 
Este libro forma parte del acervo de la Biblioteca Jurídica Virtual del Instituto de Investigaciones Jurídicas de la UNAM

Como dice Reinhard Kühnl, ya los fisiócratas franceses, haciendo referencia a la agricultura, habían formulado la doctrina de que el individuo tenía que ser dueño de sus propios intereses económicos para que pudiera tener lugar una distribución armónica de la actividad y la propiedad. Según esa doctrina, era tarea del Estado suprimir todos los obstáculos que se opusieran al orden natural. A partir de Adam Smith, la economía debía desarrollarse según leyes naturales en provecho del bienestar común, siempre y cuando se le diera libre curso. De esta forma, el Estado tenía que garantizar las bases de una sociedad de propietarios particulares autónomos mediante la salvaguarda de principios jurídicos como: la autonomía privada de la voluntad, la libertad del contrato, la libertad de comercio, de la propiedad, de la herencia y de la libre competencia del mercado. ${ }^{82}$

Las ideas liberales de Smith y sus seguidores, fueron puestas en duda por los que consideraron que no podían generarse las condiciones de excelencia del mercado, porque en él había algunos que carecían de propiedad, y que obligados por las circunstancias, entraban en relaciones contractuales de desigualdad y de subordinación con los poderosos, precisamente por carecer de propiedad. Además, la pretensión de una economía libre de monopolios no era sostenible porque los procesos de acumulación de riqueza y de explotación a la clase trabajadora conducen a que algunos tengan más influencia que otros en las actividades económicas. En circunstancias de asimetría, señalaron, entre otros, los utilitaristas, los intercambios libres son sólo una presunción..$^{83} \mathrm{El}$ error de la economía liberal clásica es que presuponía para su éxito una sociedad integrada por pequeños productores o productores de pequeñas mercancías.

Como ha puesto de manifiesto Habermas: "el poder económico de cada propietario de mercancías se sitúa dentro de una escala de magnitudes en la cual no pueden ejercer influencia alguna sobre el mecanismo del precio, por lo que nunca puede llegar a constituir un poder sobre otros propietarios de mercancías". ${ }^{84}$ Sólo en esas condiciones, de simetría y de imposibilidad para influir en los precios, podía resultar un equilibrio entre la oferta y la demanda; además, eran necesarios individuos con las mismas oportunidades de adquirir la condición de propietario, y en consecuencia, la de contar con las características del hombre de la teoría liberal, económicamente independiente y políticamente emancipado.

\footnotetext{
82 Kühnl, Reinhard, "El liberalismo", op. cit., p. 79.

83 Bentham, Jeremy, Un fragmento sobre el gobierno, Madrid, Tecnos, 2010.

84 Habermas, Jürgen, Strukturwandel der Öffentlichkeit, Neuwied, 1962, p. 94.
} 
Este libro forma parte del acervo de la Biblioteca Jurídica Virtual del Instituto de Investigaciones Jurídicas de la UNAM

\section{LAS IDEAS QUE PROPICIARON EL ESTADO LIBERAL DE DERECHO}

Durante los siglos XVII y XVIII se expresó en algunos países de Europa un gran movimiento intelectual, que cimbró las bases y fundamentos del Estado absoluto. En Francia se llama Enciclopedia por la magna obra que publicaron filósofos de cultura francesa - Voltaire, Diderot, D'Alembert- que influyeron decisivamente en su sociedad y fueron el sustento teórico de la posterior Revolución francesa. En Alemania se le conoce como Ilustración e implicó, por el impacto de autores como Kant, ${ }^{85}$ entre otros, el postulado que señalaba y promovía la capacidad de cada ser humano para servirse de su inteligencia, sin la guía de otros, para realizar sus propios planes y proyectos de vida. En Gran Bretaña, David Hume, expone la necesidad de justificar todos los principios del derecho natural - para cuestionar tanto la moral objetiva como para debilitar la teoría del origen divino de los reyes - ${ }^{86}$, y John Locke, propone en su teoría del contrato, que las personas cuando realizan el pacto de creación del Estado, no le ceden a éste todos sus derechos, pues la vida, la libertad, y destacadamente la propiedad, son inherentes a todo ser humano, y por tanto, es obligación de las instituciones tutelar y salvaguardar esos derechos, ya que su preservación constituye el fundamento de legitimidad del propio Estado. ${ }^{87}$

Sin embargo, el precursor de la ideología liberal que conforma el Estado liberal de derecho es paradójicamente Hobbes (ya que también es un teórico del Estado absoluto), pues entendió que el poder político se apoya en un acto de voluntad humana racional. La sociedad política no tiene un origen natural sino artificial: las personas construyen con las demás al Estado a través de un contrato. El Estado hobbesiano exige premisas individualistas, en tanto que cada individuo a través de su razón, libertad y voluntad, decide realizar el Estado, y éste existe y se justifica, en cuanto sirve para el provecho de cada persona. El individuo debe obediencia al Estado verdadero, que es aquel capaz de salvaguardar la paz social y la seguridad; el Estado será instrumento de esos objetivos que permitirán la realización libre y con seguridad de las actividades económicas. ${ }^{88}$

\footnotetext{
85 Kant, Immanuel, ¿Qué es la ilustración?, Madrid, Alianza Editorial, 2007.

86 Hume, David, Tratado de la naturaleza humana, 4a. ed., Madrid, Tecnos, 2005.

87 Locke, John, Segundo tratado sobre el gobierno civil: un ensayo acerca del verdadero origen, alcance y fin del gobierno civil, Madrid, Tecnos, 2006.

88 Hobbes, Thomas, Leviatán o la materia, forma y poder de una República eclesiástica y civil, op. cit., capítulo 17, p. 137.
} 
Este libro forma parte del acervo de la Biblioteca Jurídica Virtual del Instituto de Investigaciones Jurídicas de la UNAM

La aportación de Locke a la teoría del contrato y del Estado liberal, que se elabora sobre los cimientos de Hobbes, es el reconocimiento de los derechos humanos. Se trata de derechos, que como ya se dijo, son anteriores a la constitución de la sociedad y el Estado. Dentro de los derechos fundamentales destaca el derecho de propiedad. La teorización de Locke sobre la propiedad y sobre los derechos significa que el Estado esta constreñido exclusivamente a los fines de concreción de esos derechos, y por tanto, es neutral y no puede imponer creencias religiosas ni concepciones acerca del bien. Para la defensa de los derechos, y fundamentalmente de la propiedad, existen controles a la acción del gobierno: el sometimiento de los poderes al principio de legalidad - Rule of Law - la división de poderes para prevenir cualquier exceso en el ejercicio del poder; un gobierno representativo que expresa el origen consensual y limitado del poder, y finalmente, un derecho a la resistencia y a la revolución, para que los ciudadanos revoquen el poder de los representantes cuando éstos devienen en tiranos por no garantizar los derechos básicos.

Para autores como Macpherson, la teoría de Locke constituye una anticipación de lo que denomina individualismo posesivo, ${ }^{89}$ porque sus bases conceptuales delinean las condiciones de las sociedades capitalistas: el Estado y el orden jurídico están para proteger los derechos, esencialmente, al de propiedad, que jamás es puesto en duda como derecho humano. Ignacio Sotelo dice que a Locke se le descomponen las cosas cuando de la bonanza inicial que trae consigo la constitución del Estado, la población aumenta en sus dimensiones y se reducen las tierras disponibles, y también, cuando gracias a la invención del dinero se descubre la acumulación de la riqueza sin término ni medida.

Locke no crítica la desigualdad que ocasiona la invención del dinero ni controvierte que los que no tienen medios suficientes para subsistir vendan su fuerza de trabajo. Locke tipifica los dos elementos que constituyen el capitalismo: la propiedad privada de los bienes de producción y la compraventa de la fuerza de trabajo. Además, para Locke el poder de juzgar y hacer la paz y de declarar la guerra debe ser un poder limitado, ya que sólo se puede ejercer en defensa de la propiedad y demás derechos de los ciudadanos. El Estado goza de un poder que está siempre restringido por los derechos sagrados que provienen del estado de naturaleza. El modelo de Estado de Locke es liberal porque se apoya en un poder limitado que implica: división de poderes, gobierno por consentimiento, principio de la mayoría,

89 Macpherson, G. B., La democracia liberaly su época, Madrid, Alianza Editorial, 1981. 
Este libro forma parte del acervo de la Biblioteca Jurídica Virtual del Instituto de Investigaciones Jurídicas de la UNAM

y gobierno monárquico que comparta el poder con un sistema parlamentario. Todo ello para la defensa de la propiedad y los demás derechos que son parte de su preocupación. ${ }^{90}$

Con autores posteriores, como Rousseau, ${ }^{91}$ el derecho de propiedad recibió críticas que no opacaron en Europa ni en el nuevo mundo, la tendencia general de carácter filosófico a justificarla y a considerarla pilar y objetivo fundamental del Estado. Para Rousseau la propiedad privada es un derecho individual sagrado; sin embargo, sólo es sagrada la propiedad moderada del pequeño propietario que la trabaja. Un derecho ilimitado a la propiedad conduce a la explotación de los otros y a la falta de libertad. En Rousseau una sociedad verdaderamente democrática requiere de tal igualdad en la propiedad que ningún ciudadano sea lo bastante opulento para comprar a otro, y ninguno lo bastante pobre para ser constreñido a venderse. El ginebrino señalaba de manera clarividente que cuando las diferencias de propiedad dividen a los seres humanos en clases con intereses opuestos, se regirán por intereses de clase, que son intereses particulares que no pueden expresar la voluntad general orientada al bien común. Una de las funciones básicas de todo gobierno es prevenir la desigualdad, no arrebatando la riqueza a sus poseedores, sino privándolos de los medios de acumularla; no mediante la construcción de hospitales para los pobres, sino impidiendo que los ciudadanos sean pobres. ${ }^{92}$

En los Estados Unidos, uno de los pocos defensores de la igualdad en la propiedad es Thomas Jefferson. El norteamericano sostenía que la dependencia engendra servilismo y venalidad. A su juicio, la democracia exigía una sociedad en la que todos fuesen económicamente independientes. En el contexto de esa época, en los Estados Unidos, Jefferson no tenía objeciones al trabajo asalariado porque los norteamericanos en esos tiempos podían disponer de tierras gratis. Tampoco ponía objeciones a que algunos como él mismo, poseyeran grandes fincas, siempre que los demás tuvieran el mismo derecho, al menos a poseer una pequeña finca que les diera independencia. Para Jefferson el requisito previo para la existencia de una democracia, al igual que en Rousseau, era una sociedad de una sola clase. ${ }^{93}$

Más tarde, con el utilitarismo inglés, que reniega de una moral objetiva que justifique los derechos humanos, se apoya una ética consecuencialista,

\footnotetext{
90 Sotelo, Ignacio, El Estado social. Antecedentes, origen, desarrollo y declive, Madrid, Trotta, 2010, pp. 40-43.

91 Rousseau, Jean Jacques, Discurso sobre el origen de la desigualdad entre los hombres, Madrid, Editorial Delta, 2013.

92 Macpherson, C. B., op. cit., pp. 26-28.

93 Ibidem, p. 29.
} 
Este libro forma parte del acervo de la Biblioteca Jurídica Virtual del Instituto de Investigaciones Jurídicas de la UNAM

en la que la búsqueda de la utilidad y la felicidad individuales se combina con una ética igualitarista que se manifiesta tanto en el reconocimiento de que todos los intereses y deseos de los individuos son igualmente dignos de consideración como en el principio que sostiene maximizar la utilidad del mayor número de individuos, lo que puede conducir a proyectos de reforma social. Estas ideas, ya son propias del siglo XIX, cuando se comenzaron a sentir los efectos económicos del Estado liberal de derecho. Primero, fueron expresadas por James Mill y Jeremy Bentham ${ }^{94}$, y posteriormente, con mayor rigor por John Stuart Mill. ${ }^{95}$ Éste distinguió entre intereses de orden superior y de orden inferior. Los intereses y deseos inferiores son necesarios para satisfacer un nivel mínimo de vida, y no se puede pasar a los intereses superiores, si los inferiores no quedan satisfechos. ${ }^{96}$ Esta tesis conduce a limitar la autonomía de la voluntad y a la imposición de políticas públicas de carácter general para paliar los efectos de la desigualdad. ${ }^{97}$ Sin embargo, siendo John Stuart Mill un defensor del principio de libertad, cómo conciliaba la reducción de la autonomía individual con la garantía más plena de la libertad. La respuesta de Mill escrita en su ensayo "Sobre la libertad" es la siguiente: la única parte de la conducta por la cual es responsable ante la sociedad es aquella que afecta a los otros. En la que únicamente afecta al individuo su derecho a la libertad es absoluta. ${ }^{98}$ De esta suerte, John Stuart Mill es un defensor del derecho a la disidencia frente a las mayorías y frente al propio Estado cuando éstos invadían el marco de la intimidad personal y familiar. En lo demás, cuando nuestra libertad afecta a otros, Stuart Mill es un defensor de la promoción de políticas públicas que generen condiciones igualitarias en la sociedad.

Kant, que proviene de la tradición contractualista, sostiene que la idea del Estado debe estar ajustada a tres principios a priori del derecho: 1) la libertad de cada miembro de la sociedad en cuanto persona; 2) la igualdad de todos entre sí en cuanto súbditos, y 3 ) la autonomía en cuanto ciudadano de cada miembro de la sociedad..$^{99}$ Kant estimaba que el contrato social para justificar el Estado y el derecho es una idea regulativa. Con ello, quería

\footnotetext{
94 Bentham, Escritos Económicos, México, Fondo de Cultura Económica, 1978, p. 38.

95 Stuart Mill, John, Sobre la libertad, Madrid, Tecnos, 2008.

96 Stuart Mill, John, El utilitarismo, Madrid, Alianza Editorial, 1984, pp. 100 y ss.

97 Los utilitaristas, y particularmente John Stuart Mill, señalaron límites precisos al principio liberal de laisser-faire para garantizar condiciones materiales más igualitarias en la sociedad. Stuart Mill, John, Principios de economía política, México, Fondo de Cultura Económica, 1985, pp. 804 y ss.

98 Stuart Mill, John, Sobre la libertad, op. cit., p. 66.

99 Kant, Immanuel, "En torno al tópico: tal vez eso sea correcto en teoría, pero no sirve en la práctica", Teoría y práctica, Madrid, Tecnos, 1986; mismo autor, La paz perpetua,
} 
Este libro forma parte del acervo de la Biblioteca Jurídica Virtual del Instituto de Investigaciones Jurídicas de la UNAM

afianzar la naturaleza moral de la persona y no deducirla de consideraciones historicistas o antropológicas para dotar de contenido categórico a los derechos humanos. Las declaraciones de derechos, como Kant hubiera sostenido, extraerán la libertad y la dignidad moral de las personas del flujo de la historia y se impondrán como un absoluto, debiendo prevalecer sobre cualesquiera que sean las contingencias de la vida social. Hasta hoy en día, el debate sobre la fundamentación de los derechos humanos descansa en si los podemos justificar a partir de principios morales objetivos, o si son consecuencia de las circunstancias económicas, sociales e históricas de cada momento: ¿Pues por qué las sociedades estiman como derechos humanos con determinados alcances ciertas situaciones en circunstancias específicas y por qué en otras no los aprecian así, o no los han comprendido así? Nosotros sostenemos que los derechos humanos tienen, independientemente de la discusión sobre la existencia de una moral objetiva, un fundamento económico, histórico y social innegable.

Con el avance del sistema económico capitalista durante el siglo XIX, el modelo filosófico y económico del Estado liberal, entró en crisis por las diferencias sociales abismales que producía. Las principales premisas económicas del Estado liberal dejaron de tener sentido: ya no existía un bienestar común que pudiese ser establecido en forma objetiva; el interés ganancial de los distintos propietarios de mercancías no era evidentemente idéntico al interés común; el trabajador asalariado no disponía prácticamente de ninguna oportunidad de alcanzar el estado de propietario; ya no estaba dado el equilibrio de las fuerzas, premisa de su libertad, puesto que en caso contrario aquéllas se convertirían en lo opuesto; ya no existía la libre competencia entre los propietarios de mercancías, por lo que las grandes empresas económicas podían ejercer una profunda influencia sobre el mercado; y como ya lo había visto Hegel, la idea liberal se había convertido, debido al desarrollo social, en ideología justificativa de una mala realidad. ${ }^{100}$

\section{LAS REVOLUCIONES QUE GONSOLIDARON EL ESTADO LIBERAL DE DEREGHO}

Los cambios económicos tendentes al desarrollo del capitalismo más las nuevas ideas filosóficas, políticas y jurídicas, son la base del Estado liberal de derecho. Las ideas filosóficas del liberalismo condujeron al constitucionalis-

Madrid, Tecnos, 1985; mismo autor, La metafisica de las costumbres, Madrid, Tecnos, 1989, pp. 139-165.

100 Kühnl, Reinhard, "El liberalismo", op. cit., p. 86. 
Este libro forma parte del acervo de la Biblioteca Jurídica Virtual del Instituto de Investigaciones Jurídicas de la UNAM

mo moderno: declaraciones de derechos humanos, separación de poderes y Estado liberal de derecho. El absolutismo estaba herido de muerte y las llamadas revoluciones burguesas como las inglesas de 1648 y 1688, la americana de 1776 y la francesa de 1789, sólo confirmaron lo que en el ámbito de la economía y de las ideas se había fraguado. El liberalismo fue la ideología que reivindicó las necesidades de esa época. Después, la noción de Estado liberal de derecho, consolidaría las nuevas concepciones para beneficiar a la clase triunfadora de los procesos, que fue la burguesía. ${ }^{101}$

Las revoluciones inglesas de 1648 y 1688 se entienden generalmente como enfrentamientos entre la aristocracia celosa de preservar sus privilegios y la burguesía incipiente que reclamaba espacios de poder. Los reyes ingleses que poseían una armada importante a su servicio no disponían de un ejército permanente ni de una administración pública profesional. Los grupos sociales - baja nobleza y burguesía - que realizaban esas tareas en beneficio de la monarquía pedían representación en el Parlamento. Éste fue convocado y significó en 1949 la ejecución del rey Carlos I y la proclamación de la Commonwealth, que en 1953, adquirió el carácter de protectorado bajo Oliverio Cromwell y del hijo de éste, Ricardo, los que gobernaron hasta 1660, en donde un nuevo Parlamento, restaura la monarquía pero bajo condiciones continuadas de disputa con la Corona. En 1688, una revolución incruenta - la Revolución Gloriosa - permite un arreglo entre Parlamento y monarquía, lo que pone fin al prolongado conflicto y sienta las condiciones de la supremacía del Parlamente sobre la monarquía. Ese acontecimiento entrañó el acceso al poder político de las élites bancarias, mercantiles y agrícolas, que instauraron una nueva fisonomía económica: la libre empresa y el individualismo posesivo.

La independencia de los Estados Unidos es hija de estas influencias. Los colonos del nuevo mundo entendieron que sus derechos humanos precedían a todo poder público y que éste se legítima sólo al proteger los derechos. Cuando el Estado no tiene su origen en los derechos humanos, o los desconoce, o no es capaz de protegerlos, es ilegítimo. Como sabemos, la independencia norteamericana formalmente empezó como un conflicto jurídico porque el imperio británico exigía contribuciones, sin que los colonos hubiesen participado, en violación a sus derechos, en la redacción y aprobación de esos tributos. En el fondo de la disputa, los colonos norteamericanos requerían plena libertad económica, sin trabas gubernamentales, para realizar sus transacciones. Zagrebelsky señala que:

101 Vallespín, Fernando, "El Estado liberal”, en Águila, Rafael del, Manual de ciencia politica, Madrid, Trotta, 1997, pp. 54-58. 
Este libro forma parte del acervo de la Biblioteca Jurídica Virtual del Instituto de Investigaciones Jurídicas de la UNAM

Para la concepción americana, los derechos son anteriores tanto a la Constitución como al gobierno... Según la famosa argumentación "circular" del Federalist de ascendencia lockeana (derechos naturales de los ciudadanos, soberanía popular, delegación en los gobernantes del poder necesario para la protección de los derechos), las Cartas constitucionales eran el acto mediante el cual el pueblo soberano delegaba libremente en los gobernantes. El poder de éstos se basaba en esa delegación y, naturalmente, debía permanecer dentro de los límites marcados por ella, más allá de los cuales se produciría la absoluta nulidad de sus actos... ${ }^{102}$

Es evidente que con esta manera de entender la realidad jurídico-política se estaba defendiendo no sólo una visión de los derechos inherentes al ser humano y anteriores a toda Constitución y organización política, sino también una manera de concebir la organización económica de los integrantes de la sociedad, para que éstos pudieran desarrollar con plena libertad y sin obstáculos sus derechos económicos. Libertad, como lo ha advertido Macpherson, puede significar la libertad de los fuertes para aplastar a los débiles mediante la aplicación de las normas del mercado más que el otro concepto, ingenuo, que señala que la libertad debe permitir que todos efectivamente utilicen y desarrollen sus capacidades. ${ }^{103}$

Respecto a Francia, en 1788, el rey Luis XVI se vio forzado a convocar a los Estados Generales, donde el Tercer Estado - la burguesía - se proclamó como Asamblea Nacional representante de la nación. El 14 de julio de 1789, las revueltas populares inician la Revolución francesa y suponen el fin de la monarquía absoluta, la instauración de distintos gobiernos revolucionarios que proclaman los derechos humanos y la división de poderes y en general, el advenimiento de nuevas formas de gobierno y autoridad que promueven el desarrollo capitalista. La Revolución francesa, en todas sus etapas, inició el régimen del terror y la conquista del poder por Bonaparte. Significando siempre la alianza de la burguesía con distintos grupos sociales y políticos para consolidar su hegemonía económica y social.

Desde el punto de vista jurídico-institucional, la Revolución francesa entrañó el aumento del poder del Estado y la centralización política. ${ }^{104}$ Los poderes intermedios de la nobleza, la Iglesia y las corporaciones locales que mediaban entre el monarca y el pueblo, quedaron destruidos. La igualdad formal ante la ley que proclamó la Revolución francesa, debilitó los sentidos

102 Zagrebelsky, Gustavo, El derecho dúctil. Ley, derechos, justicia, Madrid, Trotta, 1995, p. 55.

103 Macpherson, C. B., op. cit., p. 10.

104 Tocqueville, Alexis, El antiguo régimen y la revolución, Madrid, Fondo de Cultura Económica de España, 1996. 
Este libro forma parte del acervo de la Biblioteca Jurídica Virtual del Instituto de Investigaciones Jurídicas de la UNAM

corporativistas de la sociedad y alentó el engrandecimiento del Estado que requirió de una nueva concepción del derecho basada en cimientos racionalistas e individualistas compatibles con el desarrollo capitalista de la época.

\section{EL MODELO JURÍDICO DEL ESTADO \\ LIBERAL DE DERECHO}

La burguesía, clase triunfante de las revoluciones liberales y del estado de cosas imperante buscó institucionalmente limitar al Estado absoluto. La concreción del Estado liberal de derecho consiste en una racionalización y delimitación de la autoridad para que los miembros privilegiados de la sociedad pudiesen desarrollar con libertad la esfera de sus derechos, señaladamente el de propiedad y el de libre contratación, sin que el Estado intervenga, salvo para apoyarlas, en esos ámbitos. Por eso, la concepción jurídica del Estado liberal de derecho se apoya en algunas variables y categorías jurídicas precisas que delimitan a la autoridad: 1) declaraciones de derechos humanos; 2) división de poderes; 3) principio de legalidad; 4) control de los actos de la administración vía el principio de legalidad, y 5) la existencia de jueces independientes. Estas categorías jurídicas, a su vez, suponían otras, como la existencia de algunas autoridades representativas electas por los ciudadanos mediante los partidos de notables y el voto censitario, además del principio de autonomía de la voluntad, que permitía a los súbditos o ciudadanos, según fuera el caso, celebrar todos los actos jurídicos que consideraran necesarios y que no estuviesen prohibidos por la ley.

Las declaraciones de derechos de finales del siglo XVIII y principios del siglo XIX, a diferencia de las declaraciones medievales, implicaban la organización racional del poder desde principios generales para limitarlo, y los derechos que se reconocen en esos documentos, ya no contemplaban a la persona como parte de un estamento como en la Edad Media, sino que entienden que los derechos corresponden a la generalidad de los hombres, independientemente de su estamento o clase social. Los derechos humanos constituyen así, la primera limitación al poder del gobernante; son barreras infranqueables que éste no puede traspasar porque si lo hace, su poder deviene en ilegítimo.

Las declaraciones más famosas de la época son ilustrativas de lo que aquí se señala. La Declaración Francesa de Derechos del Hombre y el Ciudadano del 26 de agosto de 1789, en su artículo 1o., indica: "Los hombres nacen y permanecen libres e iguales en derechos". El preámbulo de la Declaración de Independencia de los Estados Unidos del 4 de julio de 1776 
Este libro forma parte del acervo de la Biblioteca Jurídica Virtual del Instituto de Investigaciones Jurídicas de la UNAM

dice que los derechos del hombre, que comprenden el derecho a la vida, la libertad y la búsqueda de la felicidad, son evidentes en sí mismos, y que el gobierno se instituye como garantía de esos derechos. De esta suerte, las declaraciones de derechos se caracterizan: 1) por considerar a los derechos humanos como universales, pues se entiende que corresponden a toda persona independientemente de su nacionalidad, raza, sexo, lengua o religión; 2) son reconocidos más no creados por el Estado, son anteriores al mismo y al orden jurídico, y 3) los derechos humanos son derechos morales que se derivan de la humanidad de cada cual y están dirigidos a la protección de la dignidad de toda persona; sin embargo, también son jurídicos porque se positivan por el orden jurídico respectivo.

Las Declaraciones y Constituciones decimonónicas reconocieron en sus textos exclusivamente derechos humanos de carácter liberal, derechos civiles y políticos. No contemplaron derechos económicos, sociales, culturales, o de otra naturaleza que promovieran la igualdad entre las personas, porque ésta se daba equivocadamente por supuesta. Claramente se trataba de derechos compatibles con la libertad económica y de comercio, en donde como había señalado Adam Smith, el Estado sólo tenía obligaciones de abstención - de no hacer - no podía interferir en el ejercicio y goce de los derechos humanos de libertad, salvo para garantizarlos y protegerlos frente a las acechanzas de las mayorías o de la autoridad.

Los sistemas jurídicos, dependiendo de la tradición de cada Estado, dieron un tratamiento diferenciado a los derechos. En el caso de los Estados Unidos, los derechos humanos eran claramente pre estatales - existían independientemente de la voluntad del Estado-, subjetivos porque correspondían y eran inherentes al patrimonio personal de todas las personas, y jurisdiccionales, porque se tutelan en ese país a través de un esquema de defensa de los derechos - el Judicial Review — que se entiende como la actividad central de los jueces a través del control oficioso de constitucionalidad realizado por cualquier juez federal. En Francia, los derechos tuvieron una impronta estatalista porque se requería el reconocimiento jurídico del Estado para su existencia; objetivos, porque su aceptación y garantía venía determinada por disposiciones legales secundarias, y de carácter legislativo, porque para hacerlos valer se requería que una ley formal y materialmente estableciera las vías y condiciones para su ejercicio. ${ }^{105}$ No obstante estas diferencias, que se deben fundamentalmente a la cultura jurídica de cada país, lo cierto es que el ámbito de los derechos humanos estaba limitado a unas cuantas materias - la libertad de expresión, de contratación, de reunión,

105 Zagrebelsky, Gustavo, op. cit., pp. 47 y ss. 
Este libro forma parte del acervo de la Biblioteca Jurídica Virtual del Instituto de Investigaciones Jurídicas de la UNAM

etcétera-, y a unas cuantas personas, que por su ilustración o fortuna los ejercían; así, entre los derechos políticos, el derecho al voto no fue universal para la hombres sino hasta finales del siglo XIX, y en el caso de las mujeres, hasta bien entrado el siglo XX. No es casual que Carlos Marx condenara estos derechos por considerarlos derechos del burgués. ${ }^{106}$

En ambos sistemas, y lo trascendente para lo que aquí se explica, es que las declaraciones de derechos — más allá y en muchos de los casos de su carácter meramente retórico - fueron limitaciones al poder público y también a la influencia de las mayorías que podían poner en riesgo la libertad económica. Ni la autoridad ni las mayorías podían menoscabar el ámbito sagrado de los derechos. La conceptualización de los derechos claramente fue un límite moral, político y jurídico al otrora poder absoluto de la autoridad y un factor de la consolidación del poder económico y político de la burguesía.

La división de poderes en su versión del Estado liberal de derecho se debe primero a Locke y después a Montesquieu. ${ }^{107} \mathrm{El}$ modelo de éste se guió por la práctica de los frenos, contrapesos y controles del sistema británico, pero es en realidad una racionalización del poder que se prefería deseable para no concentrarlo más en uno sólo de los poderes; se trataba de una garantía para disminuir la fuerza del monarca absoluto. Las características del principio de división de poderes implican: 1) dividir las funciones del Estado - legislativas, ejecutivas y judiciales - en tres poderes. La legislativa se atribuye al Parlamento, la ejecutiva al gobierno, y la judicial a los jueces, y 2) los poderes se relacionan entre sí por un sistema de controles mutuos. No están separados totalmente, sino que cooperan entre ellos para que el sistema político pueda ser eficaz y eficiente, pero al mismo tiempo, se fiscalizan mutuamente para evitar un ejercicio abusivo del poder de alguna de las ramas del Estado.

El principio de división de poderes ha tenido dos expresiones: la presidencialista de los Estados Unidos desde 1787, y la parlamentaria de los países europeos. ${ }^{108}$ En su versión presidencialista, el presidente, titular del Ejecutivo, no es miembro del parlamento - se elige por separado- y los miembros del gabinete son designados y removidos libremente por él. El Congreso integrado por dos Cámaras no tiene facultades para censurar al

106 El poder del Estado se empleó como un instrumento y herramienta de clase; sirvió para respaldar esos métodos y sistemas en beneficio de la burguesía y la consolidación del capitalismo. Marx, Carlos, op. cit., pp. 638 y 639.

107 Montesquieu, Charles de Secondat, Del espíritu de las leyes, Madrid, Tecnos, 2007.

108 García Pelayo, Manuel, Derecho constitucional comparado, Madrid, Alianza Editorial, 1984. 
Este libro forma parte del acervo de la Biblioteca Jurídica Virtual del Instituto de Investigaciones Jurídicas de la UNAM

ejecutivo, y lo más que puede hacer, es destituirlo de su puesto mediante el impeachment en determinados supuestos jurídicos. El presidente tiene poderes de veto sobre las leyes que aprueba el Congreso, pero éste puede superar el veto por mayorías calificadas determinadas en cada Constitución. El presidente tiene facultades para proponer al Senado a los integrantes de la Corte Suprema. El Congreso, por su parte, tiene facultades para aprobar el presupuesto, con aprobación de una Cámara o de las dos, dependiendo de cada sistema constitucional y tiene numerosas facultades, control y vigilancia sobre el Ejecutivo, además de que nunca puede ser disuelto por éste. En cuanto al judicial, sobre todo en el sistema norteamericano, goza de gran independencia respecto a los otros dos poderes para interpretar la Constitución, aunque sobre determinadas materias no tiene competencia.

En su versión parlamentaria, ${ }^{109}$ que ha sido la dominante en Europa, se habla de una separación de poderes flexible, la que consiste en la íntima dependencia entre Ejecutivo y Legislativo y viceversa. El Ejecutivo puede disolver al Parlamento y convocar a elecciones, y el Parlamento, puede censurar al Ejecutivo mediante una moción de censura y privarlo de su cargo. El Ejecutivo debe contar en todos los casos con la confianza del Parlamento o de su mayoría. El gobierno forma parte del Parlamento, aunque éste tiene funciones de control sobre el gobierno a través de preguntas, mociones, comisiones de investigación, aprobación del presupuesto, etcétera. Las cúspides del Poder Judicial, y ahora de los tribunales constitucionales, aunque se derivan de los Poderes electos, gozan de independencia y conocen en general de cualquier materia, a diferencia del sistema norteamericano en donde ciertos temas - Justiciability Doctrines y Political Questions - no son de la competencia de los tribunales y puede, en algunos casos, anular leyes que sean contrarias a la Constitución, como en el sistema norteamericano.

El modelo parlamentario europeo, sobre todo el francés del siglo XIX, resulta interesante para nuestra descripción, porque el primer objetivo de la burguesía consistió en hacerse del Poder Legislativo para someter al Ejecutivo y al Judicial. Aunque en la teoría el legislativo representaba el interés general y era una manifestación de la razón, en los hechos, el Parlamento se convirtió en el más importante de los poderes - manifestación del poder de la burguesía - en tanto que las actuaciones del Ejecutivo y en concreto de la administración, no podían realizarse sino existía una ley que lo autorizara,

109 Uno de los trabajos más luminosos sobre la superioridad del régimen parlamentario sobre el presidencial se encuentra en: Linz, Juan, "Democracia presidencial o parlamentaria: ¿Qué diferencia implica?”, en Democracias: quiebras, transiciones y retos, obras escogidas, Madrid, Centro de Estudios Políticos y Constitucionales, 2009, t. IV, pp. 450-531. 
Este libro forma parte del acervo de la Biblioteca Jurídica Virtual del Instituto de Investigaciones Jurídicas de la UNAM

que es lo que conocemos como principio de legalidad y que ha sido desde entonces, una poderosa arma jurídica para enfrentar la arbitrariedad y hasta la discrecionalidad del Ejecutivo. En cuanto al Judicial, en el siglo XIX en Francia predominó la escuela de la exégesis, que fue una concepción teórica que redujo el papel de los jueces a simples operadores mecánicos y pasivos de la ley, aplicadores de silogismos y realizadores de subsunciones de los casos a las normas, sin que pudieran aportar nada a través de la interpretación para atribuir significados normativos. ${ }^{110}$

La fortaleza del Legislativo, que como ya hemos visto, significaba el poder de la burguesía, se veía robustecida por el carácter o naturaleza de los partidos políticos que se representaban en el Parlamento, y por la existencia del voto censitario, que impedía que los trabajadores o sectores socialmente débiles estuviesen representados. Los partidos eran de notables organizaciones de burgueses que eran capaces de vivir para la política sin tener que vivir de ella. Los partidos de notables no representaban intereses sociales diversos y encontrados, en tanto que todos los diputados eran integrantes de la burguesía, y como tales, tenían diferentes opiniones sobre los temas, pero esas diferencias entre caballeros no ponían en duda las bases del sistema o modelo económico de vida imperante. La idea de revolución o de conflicto violento se había domesticado en el Parlamento del siglo XIX para volverse una controversia continuada, pacífica e institucionalizada. ${ }^{111}$ El voto censitario era muy útil a lo anterior porque excluía a los sectores sociales o económicos que podían ser conflictivos con los intereses dominantes.

El Estado liberal de derecho tuvo que ser modificado al final del siglo XIX y todo cambió “...en la medida en que unas capas no burguesas irrumpen en la vida política pública y toman posesión de sus instituciones, participando en la prensa, los partidos y en el parlamento, el arma de la burguesía, vuelve su punta contra ella misma...". ${ }^{112}$ De esta suerte, el ámbito de lo social, de la producción económica, hasta ese momento confiado a la autonomía privada, se convirtió en asunto de discusión pública.

La otra arma del Estado liberal de derecho contra el Estado absoluto, en contra de la autoridad y del poder de las mayorías, fue y ha sido el principio de legalidad, que en realidad es una suerte de principio de legitimidad para el poder establecido, y como sabemos, reza que la autoridad exclusi-

110 Cárdenas Gracia, Jaime, Manual de argumentación jurídica, México, Porrúa, 2014, capítulo primero.

111 Kühnl, Reinhard, "El liberalismo", op. cit., pp. 70 y 71.

112 Habermas, Jürgen, Strukturwandel der Öffentlichkeit, op. cit., p. 142. 
Este libro forma parte del acervo de la Biblioteca Jurídica Virtual del Instituto de Investigaciones Jurídicas de la UNAM

vamente puede hacer lo que está previsto en una ley impersonal, general y abstracta. El principio de legalidad impide que las autoridades realicen actos arbitrarios y fuera de las competencias establecidas; además, la ley debe serlo, en un sentido formal y material. Formal, significa que debe ser elaborada y aprobada por los órganos legislativos de los Estados siguiendo los procedimientos determinados en normas superiores. Material, entraña que la ley debe reunir características como la generalidad para que sea aplicable a todas las personas por igual que se encuentren en sus supuestos, y abstracta, para que regule las conductas de manera permanente, no transitoria, y sin posibilidad de normar conductas retroactivamente. También debe ser impersonal para impedir leyes privativas, dirigidas a personas en lo particular.

El principio de legalidad se vincula con el principio de reserva de ley. Materias como los delitos, las penas, los impuestos y la regulación de los derechos, sólo pueden hacerse a través de las leyes en sentido formal y material. El principio de reserva de ley es una garantía más a favor de la burguesía, porque impedía que las normas de la administración regularan directamente determinadas materias que eran de interés para el mercado y para la defensa de la propiedad. Ni la vida, la libertad o la propiedad de una persona, podía afectarse o limitarse, por meras regulaciones administrativas. En esos casos se requería de una ley, tanto formal como materialmente.

Como ha explicado Gustavo Zagrebelsky, el principio de legalidad tiene variantes dependiendo de la cultura jurídica respectiva. En el mundo anglosajón se le denomina Rule of Law e implica que la afectación a la esfera de libertad de las personas, cuando procede, debe revestirse de determinadas condiciones que constituyen auténticos derechos - de defensa, prueba, presunción de inocencia, competencia de las autoridades para intervenir, etcétera- para garantizar los fines de las instituciones y los derechos humanos de los individuos. El sistema del principio de legalidad francés del siglo XIX, es muy estricto y fue heredado por los sistemas jurídicos latinoamericanos, consiste en que la autoridad sólo puede hacer aquello que expresamente le faculta la ley, pues si no hay una autorización legal, la autoridad no puede actuar. En el sistema jurídico alemán, el principio de legalidad es más laxo que en el sistema francés, y más que de legalidad se trata de que los actos de la administración tengan juridicidad; sin embargo, en este sistema como en el inglés o francés, determinadas materias sólo son competencia de una ley en un sentido formal y material. De esta suerte, el principio de legalidad en sus variantes europeas y americanas, fue un instrumento para domesticar a 
Este libro forma parte del acervo de la Biblioteca Jurídica Virtual del Instituto de Investigaciones Jurídicas de la UNAM

la administración pública y someterla a la economía y al mercado; es decir, a los intereses de la burguesía que controlaban los parlamentos. ${ }^{113}$

El principio de legalidad tiene como corolario el principio de autonomía de la voluntad que indica: "Todo lo que no está prohibido por la ley está permitido". La ausencia de leyes era un impedimento para la acción de los órganos del Estado que afectara los derechos de los ciudadanos. El principio de autonomía de la voluntad supone una autorización para la acción de los particulares y para la celebración de todo tipo de actos jurídicos, señaladamente la realización de los contratos. Los particulares podían hacer cualquier cosa, desempeñar cualquier tarea, siempre que no hubiese una ley que restringiera o limitara sus conductas.

Las consecuencias de los principios de legalidad y de autonomía de la voluntad son el control de los actos de la administración y de la administración misma. La capacidad de actuar del Ejecutivo dependía de leyes de autorización, o al menos, de leyes limitadoras al ejercicio de su actividad. La administración no era, por tanto, independiente de la ley. La tarea de la ley era disciplinar los puntos de colisión entre intereses públicos e intereses particulares mediante la valoración respectiva del poder público - es decir, del Parlamento - y de los derechos particulares, de la autoridad por un lado y de la libertad o de la propiedad por otro. Los poderes de la administración no se concebían como expresión de su autonomía, sino que se configuraban como ejecución de autorizaciones legislativas.

El Poder Judicial del siglo XIX, sobre todo en Francia, desempeñó también un papel de subordinación a la ley. El papel de los jueces era el de ser meros aplicadores mecánicos de las leyes elaboradas por el Parlamento - la boca que pronunciaba las palabras de la ley, según la famosa frase de Montesquieu- . No podían asignar significados normativos diferentes a los que el legislador había atribuido en las normas legales; eran jueces sin capacidad para reelaborar el sistema jurídico. Es en esos años se crean las Cortes de Casación, cuyo trabajo consistía en anular resoluciones judiciales que fueran más allá del contenido de la ley o de la voluntad del legislador. La interpretación y la aplicación eran la misma actividad, y la argumentación jurídica consistía en la elaboración de inferencias deductivas en donde las premisas mayores eran las normas legales a partir de las que se realizaba la deducción o la subsunción del caso concreto al enunciado normativo correspondiente. El método de interpretación por excelencia era exegético. $\mathrm{El}$ intérprete judicial era un sujeto pasivo que recibía el ordenamiento legal y desentrañaba pero no creaba o atribuía sus significados. La razón de la

113 Zagrebelsky, Gustavo, op. cit., pp. 23-27. 
Este libro forma parte del acervo de la Biblioteca Jurídica Virtual del Instituto de Investigaciones Jurídicas de la UNAM

postración del Poder Judicial a la ley, obedece a las malas experiencias que en el antiguo régimen, el Poder Judicial controlado por el monarca absoluto, efectuó. Además, el Poder Judicial no tenía la legitimidad democrática directa de la burguesía, sino que era una institución cuyos cuerpos cúspide eran integrados por la intervención del Parlamento, y en algunos casos por el Ejecutivo. El Poder Judicial, por tanto, no provenía de la soberanía de la nación y no podía hablar a nombre de ella ni representarla.

Las razones, tanto de la subordinación de la administración como del Poder Judicial a la ley, se explican jurídicamente por la necesaria unidad y coherencia del ordenamiento jurídico. Esta sistematicidad se consideraba un dato, un postulado que venía asegurado por la tendencia a esa unidad y homogeneidad de la ley en su conjunto, pues ésta representaba los intereses y aspiraciones de la burguesía. Las Constituciones del siglo XIX tenían un carácter poco normativo, pues no se podían materializar - hacerse aplicables - sin la existencia de leyes. Las leyes desarrollaban los contenidos normativos de las Constituciones y eran en los hechos las auténticas constituciones. Sin ley, al menos en el modelo europeo continental - una excepción fueron los Estados Unidos desde la resolución en 1803 del caso Marbury vs. Madison-, los principios de la Constitución eran proclamas retóricas sin contenidos normativos sustantivos. Las leyes lo podían todo porque estaban vinculadas a un contexto político-social ideal, definido y homogéneo. La burguesía había logrado en el siglo XIX que se pensara que las sociedades europeas eran monoclase, pues habían incorporado al ordenamiento jurídico de la época todas sus preocupaciones, deseos e intereses. ${ }^{114}$

Una característica propia del derecho del siglo XIX es la elaboración de los Códigos. Éstos representaban las características de excelencia de la ley - unidad, coherencia, sistematicidad, un proyecto jurídico basado en la razón, la plenitud, la generalidad y la abstracción del ordenamiento jurídi$\mathrm{CO}^{-}$- Los Códigos que siguieron al napoleónico presentaron esas notas, y además, desde el punto de vista de los problemas que planteara la realidad a los jueces o a la administración, en ellos se encontraban todas las soluciones posibles, sólo tenían que dirigirse a ellos para encontrar las respuestas. Había en los Códigos una pretensión de axiomatizar todo el derecho. Es verdad que en el siglo XIX también tuvieron su importancia métodos de interpretación como el sistemático y el analógico, para el caso de contradicciones o lagunas entre las normas legales del ordenamiento jurídico, pero su uso por parte de los jueces, era para reforzar las ideas de coherencia y plenitud del ordenamiento jurídico, porque en los Códigos podían

114 Ibidem, p. 31. 
Este libro forma parte del acervo de la Biblioteca Jurídica Virtual del Instituto de Investigaciones Jurídicas de la UNAM

hallarse todas las respuestas a las cuestiones jurídicas. Los Códigos fueron los monumentos jurídicos del pensamiento liberal burgués y expresión política que condensaba sus creencias en torno a los derechos de propiedad y de libertad contractual.

\section{LAS GRÍTICAS AL ESTADO LIBERAL DE DERECHO}

El Estado liberal de derecho pronto tuvo a sus críticos, los que observaron cómo el capitalismo liberal de pequeños propietarios autónomos carentes de influencia en el proceso de oferta y demanda, era sustituido por un capitalismo más organizado que negaba que los pequeños propietarios concurrieran al mercado en condiciones de igualdad para el provecho general. Pronto quedaron a la vista, los procesos de concentración y centralización del capital de las grandes empresas, la asunción ideológica de que el trabajo era una simple mercancía que degradaba el sentido de dignidad humana, el desarrollo tecnológico de los aparatos de producción, la formación de oligopolios en el mercado interior, la ayuda del Estado a determinadas inversiones nacionales sobre otras, y la protección de la economía interna frente a la competencia extranjera. Todo ello desmentía la libre competencia y el libre comercio, pilares económicos del Estado liberal de derecho.

Tras la armónica teoría liberal quedó al descubierto la cuestión social, la que ponía en entredicho la supuesta homogeneidad de la sociedad burguesa y sus correspondientes sistemas de dominio económico y político. La vigencia de los derechos humanos de libertad a favor exclusivamente de la burguesía había producido una sociedad profundamente desigual y dividida, en conflicto entre sus clases. Las clases trabajadoras y depauperadas fueron asumiendo discursos y conductas de exigencia que atacaban el predominio político de la burguesía y de sus bases de sustentación de carácter socioeconómico. Los procesos de concentración del capital eran inocultables, y aunque el Estado trataba de mantener la apariencia de neutralidad y ejercer exclusivamente sus funciones de Estado vigilante, en los hechos, el Estado se alió a las clases dominantes internas y se fortaleció para auxiliar a esos sectores a conquistar los mercados exteriores. Con ello, el Estado se volvió cada vez más agresivo e imperialista. La expansión capitalista y el rápido desarrollo tecnológico se unieron al aumento del aparto militar y al logro de su efectividad. ${ }^{115}$

115 Taibo, Carlos, "Rupturas y críticas al Estado liberal: socialismo, comunismo y fascismos", en Águila, Rafael del, Manual de ciencia política, Madrid, Trotta, 1997, pp. 81-105. 
Este libro forma parte del acervo de la Biblioteca Jurídica Virtual del Instituto de Investigaciones Jurídicas de la UNAM

A la par que se desarrollaban las contradicciones económicas, políticas y jurídicas del Estado liberal de derecho, diversas corrientes filosóficas y políticas, elaboraron discursos para cuestionar a ese Estado y a sus consecuencias. El socialismo fue una de las vertientes de crítica que hizo su aparición. El socialismo primitivo o utópico exigió la realización de sociedades más equilibradas e igualitarias, para lo cual, las organizaciones de trabajadores o el propio Estado, tenían que encargarse de planificar y organizar la actividad productiva, porque la autorregulación del mercado no les merecía confianza alguna. Los socialistas primitivos advertían que las desigualdades sociales y la pobreza en las sociedades decimonónicas era responsabilidad de la concentración de la riqueza que producía el capital, y de la debilidad de las nociones individualistas que eran incapaces de fundar a las sociedades en términos más comunitarios y solidarios. La exclusión que promovía la cuestión social debía combatirse recurriendo a otras formas de organización económica y social que ellos generalmente proponían en términos utópicos, aunque existieron intentos por parte de Robert Owen y Charles Fourier de llevar su visión utópica a la facticidad. ${ }^{116}$

Sin embargo, la mayor crítica filosófica provino de la obra de Carlos Marx que explicaba que el desarrollo y evolución de las fuerzas productivas determinaban el cambio social, desde el comunismo primitivo al capitalismo de su época. La clase emergente, el proletariado, tenía que hacerse del control de los medios de producción para vencer a la burguesía e instaurar formas distintas de organización económica y social: el socialismo se planteaba como una etapa intermedia y el comunismo como el tramo final. En él desaparecería el Estado y el derecho. El comunismo sería la fase de emancipación plena del ser humano. Para Marx, el conjunto de las relaciones de producción constituye la estructura económica de la sociedad, la base sobre la cual se levanta la superestructura jurídica y política. A diferencia del pensamiento de Hegel, ${ }^{117}$ estimaba que el Estado no era la quinta esencia de la razón; el Estado, es una superestructura que nace de la sociedad y de sus relaciones materiales de producción, y por ello, el Estado y el orden jurídico, están del lado de los que detentan las relaciones de producción porque desean perpetuarlas en su beneficio por el mayor tiempo posible. El Estado y el derecho son instrumentos de las clases dominantes para mantener y

116 Crick, Bernard, Socialismo, Madrid, Alianza Editorial, 1994.

117 Slavoj Zizek, explica como en Hegel, el Estado coincide con la razón y con la propia voluntad. El Estado hegeliano no es un instrumento de dominación sino de realización de la voluntad y de la razón individual y colectiva. Zizek, Slavoj, Menos que nada. Hegel y la sombra del materialismo dialéctico, Madrid, Akal, 2015, p. 212. 
Este libro forma parte del acervo de la Biblioteca Jurídica Virtual del Instituto de Investigaciones Jurídicas de la UNAM

conservar su poder. Esta idea se expone claramente en el Manifiesto comunista, en donde Marx y Engels se refieren al poder político como el poder de una clase organizada para oprimir a otra. ${ }^{118}$

En sus obras juveniles, Marx llegó a sostener que el proletariado podía acceder y controlar las relaciones de producción a través de vías pacíficas y democráticas. En sus obras de madurez rechazó tal pretensión, y estimó que sólo a través de las vías revolucionarias se podía modificar el status quo. La vía revolucionaria es posible cuando están dadas las condiciones objetivas de desarrollo de las fuerzas productivas, y al mismo tiempo, son evidentes las contradicciones en el seno de las sociedades. Para la etapa socialista, Marx proponía formas democráticas radicales, tales como la elección de todos los cargos con poder de decisión, control popular sobre los cargos, y la descentralización de las decisiones, entre otras. Marx fue un crítico con la democracia formal o burguesa porque entendía que ésta tiene por objetivo ocultar la desigualdad y la explotación del capitalismo: los supuestos derechos con los que cuenta el ciudadano político desaparecen cuando damos cuenta del hombre económico, que no tiene ningún derecho frente al ciudadano político que aparentemente sí los tiene.

La socialdemocracia, a diferencia del marxismo, tiene, a pesar de sus contradicciones internas, una visión más moderada sobre el papel y permanencia histórica del Estado y del derecho. Lassalle, uno de sus padres fundadores, estimaba que el Estado, por vías pacíficas y democráticas, podía convertirse en un agente de transformación socialista a través de la promoción, por ejemplo, de las sociedades cooperativas. Las ideas de Lassalle inspiraron en gran medida el programa político aprobado en Gotha en 1875, que dio lugar al nacimiento del Partido Socialdemócrata Alemán. ${ }^{119}$ Autores contemporáneos a él, como Bernstein, dudaban en esa época, de la debilidad y contradicciones del Estado liberal de derecho, y aducían que los elementos de tensión al interior del capitalismo se habían mitigado, por lo que el socialismo, no era un resultado inevitable del desarrollo del capitalismo, sino una simple posibilidad entre otras. Kautsky, en la misma línea que Bernstein, pensaba que la instauración del socialismo sólo podía ser el resultado de una lenta evolución del capitalismo en donde muchas de las instituciones jurídicas y políticas de éste podían jugar un papel importante en esa transformación gradual. En general, la socialdemocracia acepta, mediante su modificación, algunos principios del Estado liberal de derecho, y principalmente rechaza cualquier procedimiento de transformación no

\footnotetext{
118 Berlin, Isaiah, Karl Marx, Alianza Editorial, Madrid, 1973.

119 Sotelo, Ignacio, El Estado social. Antecedentes..., op. cit., pp. 166-168.
} 
Este libro forma parte del acervo de la Biblioteca Jurídica Virtual del Instituto de Investigaciones Jurídicas de la UNAM

asentado en fórmulas democráticas. La evolución del pensamiento socialdemócrata conducirá en el siglo XX al Estado del Bienestar, el que tiene como pilares: 1) el reconocimiento de los derechos económicos, sociales, culturales y ambientales para producir más igualdad social y económica; 2) esquemas de redistribución de la riqueza a través de las políticas fiscales y presupuestarias; 3) la realización de una "economía mixta", en donde el Estado tenga un papel destacado para reducir los efectos nocivos del libre mercado, y 4) aceptación de la economía de mercado.

Dentro del movimiento socialdemócrata se han presentado siempre dos tendencias históricas contrapuestas: la primera, de autores como Lassalle, Bernstein y Kaustky, que eran partidarios de la superación del capitalismo, y por tanto, de la instauración del socialismo por vías pacíficas y democráticas. La segunda, de socialdemócratas, que sostienen que su papel es gestionar el capitalismo y darle un carácter más civilizado, pero que de ninguna forma, el objetivo político o económico es acabar con él. ${ }^{120}$ Esta última perspectiva en sus variantes más conciliadoras, es la que ha prevalecido en el pensamiento socialdemócrata de los siglos XX y XXI, y es la que ha permitido, desde nuestro punto de vista, el desarrollo desinhibido de lo que ahora denominamos neoliberalismo.

Las posturas socialdemócratas de finales del siglo XX, tales como las de Tony Blair, Felipe González, o hasta el modelo en México de liberalismo social de Carlos Salinas de Gortari, claramente implican una dilución del Estado del Bienestar que se consolidó después de la Segunda Guerra Mundial y un regreso a las tesis liberales bajo los ropajes de la globalización neoliberal. Esas posturas reducen el tamaño del gobierno, el gasto social, privatizan empresas públicas, acentúan los elementos liberales del Estado como la libre competencia y el libre mercado, promueven la integración económica mundial, abandonan cualquier forma de proteccionismo económico, alientan la inversión privada nacional-trasnacional y son visiones teóricas que de manera simulada coinciden en alto grado con el modelo neoliberal de la globalización que privilegia a las grandes empresas trasnacionales. Las llamadas terceras vías implican capacitar a los ciudadanos para desenvolverse en una economía dinámica y competitiva de carácter nacional y mundial, dejándolos solos ante las fuerzas del mercado mundial; alentar comunidades y organizaciones voluntarias que acometan, al margen del Estado, objetivos sociales; promover movimientos políticos que asienten la prosperidad

120 Ruiz Miguel, Alfonso, "La socialdemocracia", en Vallespín, Fernando, Historia de la teoría política. Historia, progreso y emancipación, Madrid, Alianza Editorial, 2002, vol. 4, pp. 207257. 
Este libro forma parte del acervo de la Biblioteca Jurídica Virtual del Instituto de Investigaciones Jurídicas de la UNAM

en la potenciación del capital social y humano, que impulsen la fortaleza de la sociedad respecto al Estado-nación, porque según dicen ellos, cuando la sociedad es débil son unos pocos y no muchos quienes se apropian del poder y de las recompensas, y reconocer retóricamente que existen cuatro valores que deben ser armonizados - igualdad, oportunidad, responsabilidad y comunidad - que son los que pueden maximizar la libertad y el potencial de un pueblo, en donde desgraciadamente, las libertades económicas se sitúan muy por encima de las otras libertades, de la igualdad y de la solidaridad. ${ }^{121}$

Las terceras vías que pretenden ser equidistantes al socialismo y el liberalismo, suelen estar más cerca del liberalismo y del actual neoliberalismo porque privilegian los derechos liberales y el mercado. Justifican lo anterior, aduciendo el surgimiento de mercados globales; el avance tecnológico; los requerimientos empresariales de trabajadores altamente cualificados en el mundo laboral; las transformaciones en los roles tradicionales de las mujeres y los cambios en la naturaleza de la política, la que se realiza a través de los grandes medios de comunicación electrónica y por medio de un fuerte financiamiento privado - la democracia de audiencia-.

En los documentos programáticos de los partidos europeos y latinoamericanos se expone sobre la tercera vía que:

Hay en marcha una revolución tecnológica que está modificando a la sociedad. La nueva sociedad que está emergiendo de este proceso sigue siendo capitalista, pero cada vez se diferencia más del capitalismo industrial. ¿Caminamos hacia una sociedad mejor o peor? Hay motivos para la esperanza ya que podemos producir más con menos esfuerzos, pero también hay motivos de preocupación. La innovación tecnológica, hasta el momento, no se está traduciendo en muchos países en incremento de puestos de trabajo. ¿Es esto un efecto pasajero? ¿Qué puede hacerse para relanzar la producción y el empleo? ¿Cómo garantizar la solidaridad y la cohesión social?... la riqueza ha crecido más despacio que el gasto para la protección y seguridad social, lo que transmite dudas sobre la posibilidad de que éstos últimos sigan creciendo... Los cambios deterioran la legitimidad de las instituciones representativas. Además, desplazan la iniciativa política a los medios de comunicación... ${ }^{122}$

Hoy en día, los continuadores de la tercera vía proponen un equilibrio entre Estado y mercado, sin que el uno reemplace al otro por completo.

121 Blair, Tony, La tercera vía, Madrid, Ediciones Santillana, 1998; González Márquez, Felipe, Socialismo en libertad, Madrid, Galba, 1978; Salinas de Gortari, Carlos, México. Un paso dificil a la modernidad, México, Plaza and Janés, 2013.

122 Blair, Tony, op. cit., pp. 29-32. 
Este libro forma parte del acervo de la Biblioteca Jurídica Virtual del Instituto de Investigaciones Jurídicas de la UNAM

Supuestamente se trata, como dice Sotelo, de desprenderse de los dos prejuicios que de manera alternativa dominaron en el pasado: el de que basta el mercado, capaz de autorregularse, proporcionando ocupación a todos y una aceptable distribución aceptable de la riqueza, o el que afirma que no habría más solución que el Estado ejerciera un control estricto de la economía y la sociedad. ${ }^{123}$ Lo cierto es, desgraciadamente, que no existen los instrumentos y los procedimientos para lograr ese propósito de desprendimiento. En gran parte por la fuerza desmedida del capital en el mundo de la globalización neoliberal.

Si el nacimiento del Estado liberal de derecho vino acompañado de movimientos políticos revolucionarios, su ocaso también se expresó en movimientos revolucionarios, señaladamente, la Revolución bolchevique de 1917. Este movimiento que tuvo como su líder a Vladimir Lenin apostó por una especie de capitalismo de Estado y colocó al frente del mismo a un partido férreamente organizado y jerarquizado. La vida política y jurídica quedó supeditada al logro de ese objetivo y por eso se ilegalizaron los partidos políticos y se suprimieron las libertades y los elementos jurídicos del Estado liberal de derecho. ${ }^{124}$ Lenin, y posteriormente Stalin, rechazaron frente a la socialdemocracia cualquier inclinación de condescendencia con el liberalismo capitalista, y respecto al anarquismo, sostuvieron la importancia del Estado de transición socialista. El socialismo real fue enemigo del Estado liberal de derecho en todas sus manifestaciones: negó los derechos humanos, la división de poderes, el principio de legalidad, la independencia judicial, la democracia representativa, conformó Estados totalitarios ${ }^{125}$, y paradójicamente, creó una nueva clase dominante de carácter burocrático que oprimió al resto de la población con el argumento de consolidar el Estado transitorio de carácter socialista, que había de establecer las condiciones del futuro comunismo. En este sentido, el Estado y el derecho del socialismo real se pusieron al servicio de esa clase dominante, que restringió las libertades, y aunque reconoció y garantizó derechos sociales, ello no fue suficiente para reconocer y promover la dignidad de millones de seres humanos.

Los teóricos soviéticos más importantes del derecho y el Estado fueron Stucka y Pashukanis, quienes sostuvieron el carácter ideológico y de clase de ambas entidades. Fueron conscientes de que en la etapa de transición al

123 Sotelo, Ignacio, El Estado social. Antecedentes..., op. cit., p. 409.

124 Berger, Claude, Marx frente a Lenin, Bilbao, Editorial Zero, 1977.

125 Para una tipología de los regímenes no democráticos véase Linz, Juan, "Totalitarian and Authoritarian Regimes", en Greenstein, Fred I. y Polsby, Nelson W. (eds.), Handbook of Political Science, Macropolitical Theory, Massachusetts, Estados Unidos, Addison-Wesley Publishing Company, 1975, vol. 3, pp. 24-267. 
Este libro forma parte del acervo de la Biblioteca Jurídica Virtual del Instituto de Investigaciones Jurídicas de la UNAM

comunismo, debía existir un Estado socialista revolucionario - en la fase comunista tanto el Estado como el derecho desaparecerían-, lo que implicaba instrumentalizar el Estado en la etapa socialista en beneficio del proletariado por medio de la abolición de la propiedad privada de los medios de producción y el diseño de instituciones que estuvieran del lado de la clase trabajadora para propiciar una conciencia de clase revolucionaria que avanzara hacia la etapa comunista en donde finalmente las clases, la propiedad, el derecho y el Estado, se abolirían. El nuevo Estado de la revolución debía surgir para invertir totalmente las relaciones económicas, de poder, y de clase del Estado liberal burgués, aunque como dijimos en el párrafo anterior, no propició en los hechos ni libertad ni democracia dentro del proletariado. Además de la modificación en las relaciones de producción, una herramienta subordinada a esas relaciones, para estructurar el nuevo Estado revolucionario, es el derecho. Pashukanis expresa que lo más importante es entender la especificidad del derecho, la que consiste en exponer que éste reside en las relaciones de los propietarios de mercancías entre sí, lo que prueba las bases subyacentes de carácter económico en el derecho y el Estado. Este autor propone abandonar cualquier normativismo formal - Kelsen - porque se estima burgués y liberal: el fundamento de todo Estado y Derecho son sus relaciones de producción económica que han sido y serán de clase mientras no se arribe a la etapa comunista. ${ }^{126}$

El anarquismo es otro haz de doctrinas filosóficas que han sometido al Estado liberal de derecho a duras críticas. El anarquismo sostiene, en términos generales, que la sociedad se puede organizar sin recurrir a formas coactivas de autoridad. Por tanto, el anarquismo rechaza al Estado y a sus instituciones, porque como en el marxismo, entiende que la estatalidad está subordinada a la clase dominante, busca perpetuar el poder de ésta, y producir situaciones de desigualad social a su favor. ${ }^{127}$ Los pensadores anarquistas insisten en la auto-organización de la sociedad con el apoyo de modelos educativos que permitan hacer surgir a un nuevo tipo de ser humano, que a la vez sea solidario y promueva al máximo la libertad. Los anarquistas son partidarios de la espontaneidad social y de formas asamblearias de organización política. Dentro del anarquismo, encontramos muchas corrientes, algunas opuestas entre sí, entre ellas mencionamos las siguientes: 1) la mutualista de Proudhon que argumentó a favor de la propiedad privada, siempre que no se produjeran en la sociedad relaciones económicas contrarias

126 Stucka, Peteris, La función revolucionaria del derecho Estado, 62a. ed., Barcelona, 1969, y Pashukanis, Evgeny, Teoría general del derecho y el marxismo, México, Grijalbo, 1976.

127 Horowitz, Irving Louis, Los anarquistas, Madrid, Alianza, 1975. 
Este libro forma parte del acervo de la Biblioteca Jurídica Virtual del Instituto de Investigaciones Jurídicas de la UNAM

a criterios éticos; 2) la colectivista de Bakunin y Kropotkin, que reclamaron la abolición de la propiedad privada y su sustitución por la propiedad colectiva, los consejos obreros, el modelo federal y la autogestión; 3) el libertarianismo conservador contemporáneo de los Estados Unidos que pide la desaparición del Estado en beneficio de la propiedad privada y de la libre competencia; 4) el anarquismo no violento de León Tolstoi que reivindicó la educación, la desobediencia civil y métodos de resistencia en contra de las injustas circunstancias del modelo económico-social; 5) el anarquismo violento que justificó el uso de la fuerza en contra de los integrantes de las clases dominantes y de sus intereses; 6) el anarcosindicalismo, que durante el siglo XX a través de sindicatos y centrales obreras, intentó compaginar algunos principios anarquistas con las luchas sindicales y políticas, y 7) el anarquismo de algunas versiones de los movimientos sociales contemporáneos, como el ecologismo, el pacifismo o el feminismo, que mediante formas de organización libertarias promueven sus objetivos.

Los fascismos, tanto el italiano como el alemán del siglo XX, también dirigieron como realidad histórica y como teorías, críticas en contra del Estado liberal de derecho. Este pensamiento, fuertemente anclado en un principio de autoridad, rechaza las vías de legitimidad democrática del poder. En el fascismo, los elementos centrales del liberalismo se desmontan por la impronta individualista de éste y se propone la conformación de un ser humano subordinado al Estado fascista, en donde hasta su vida privada, sea supervisada por él - los derechos humanos quedan degradados- - La noción de interés general o colectivo no es construida mediante la deliberación horizontal y democrática de la respectiva sociedad, sino impuesta por el líder - no existe, por tanto, la división de poderes - . No es el mercado ni los intereses de los empresarios los que moldean la vida económica, sino que ésta la define el jefe del Estado. No existe en estas tendencias separación alguna entre Estado y sociedad, Estado y mercado, pues todo deviene de los criterios establecidos por el líder de la nación. Además, todos los movimientos fascistas se asientan en la reivindicación de las especificidades nacionales, las que promueven la cohesión social en torno a un proyecto común, que puede ser el engrandecimiento del líder o la militarización de la sociedad con fines expansionistas. ${ }^{128}$

Para los fascismos, la igualdad no está inserta en la naturaleza de las cosas, por lo que debe mantenerse la desigualdad imperante; el fascismo es enemigo del sufragio universal y del sistema parlamentario. ${ }^{129} \mathrm{El}$ discurso

128 Kühnl, Reinhard, op. cit., pp. 56-76.

129 Schmitt, Carl, Sobre el parlamentarismo, Madrid, Tecnos, 1990. 
Este libro forma parte del acervo de la Biblioteca Jurídica Virtual del Instituto de Investigaciones Jurídicas de la UNAM

del fascismo propone conseguir un orden social caracterizado por la armonía y por la supeditación de los intereses privados e individuales a las necesidades del Estado, de la nación o de la patria. El fascismo defiende los desajustes sociales y propone preservarlos a través de la disciplina, el orden público y la propaganda. En último término, el fascismo acude a la violencia para reprimir cualquier movimiento o grupo opositor. El fascismo, en sus vertientes extremas, como la alemana de la etapa nazi, está vinculado con el totalitarismo - la noción más antidemocrática de régimen político-, y con el autoritarismo, en la España de Franco o en el Chile de Pinochet. ${ }^{130}$

\section{EL FIN DEL ESTADO LIBERAL DE DERECHO}

El Estado liberal de derecho no desapareció por las críticas de las tendencias políticas y filosóficas aquí expuestas. El Estado liberal de derecho, concebido como Estado mínimo, en una sociedad que se supone se autorregula, y en donde la libertad de los pequeños propietarios autónomos debe quedar salvaguardada para el provecho general del mercado y la economía, quedó desfasado ante los procesos de acumulación y concentración del capital, tanto internos - que sucedían en el seno del Estado nacional - como externos que ocurrían en la economía internacional-, a los que nos hemos referido.

Los procesos de industrialización motivados por el desarrollo del capitalismo produjeron sociedades profundamente desiguales, con marcados conflictos entre sus clases sociales. El Estado liberal de derecho, con sus pretensiones de homogeneidad social y su ilusión de ser guiado por un proyecto ilustrado de la razón humana, era incapaz de contener y atender las diferencias de sociedades cada vez más heterogéneas y divididas en clases. La miseria y la marginación social, consecuencia de la concentración de la riqueza, no cabían en el marco de unos derechos humanos que únicamente reconocían la libertad contractual y los derechos de la propiedad. Hacía falta reconocer nuevos derechos humanos que paliaran esos inaceptables efectos sociales que se volvían en contra del capital.

La democracia decimonónica basada en partidos de notables y con participación social restringida a través del voto censitario, era obsoleta para dar cabida a nuevos grupos sociales y a actores políticos, que exigían participación activa en los asuntos públicos. Cuando el voto masculino fue universal y se legalizó, durante la segunda mitad del siglo XIX, se puso en evidencia a los partidos de masas el desencuentro con la realidad de las

${ }^{130}$ Linz, Juan, “Totalitarian and Authoritarian Regimes", op. cit., pp. 24-267. 
Este libro forma parte del acervo de la Biblioteca Jurídica Virtual del Instituto de Investigaciones Jurídicas de la UNAM

estructuras parlamentarias que se habían heredado de los movimientos sociales de los siglos XVII y XVIII, en concreto de la Revolución Gloriosa de Inglaterra, de la independencia de los Estados Unidos y de la Revolución Francesa. Se requerían, por tanto, rediseños institucionales en el sistema electoral, político e institucional, para responder a una complejidad política y social creciente.

Desde las críticas del marxismo, no podía ya aceptarse que el trabajo se entendiese como una simple mercancía; posiciones como la socialdemocracia concibieron el trabajo desde otro status jurídico, y adujeron que jurídicamente era un derecho humano que debía protegerse a través de un marco jurídico integral que regulase las relaciones obrero-patronales. Las protestas de los trabajadores no debían ser reprimidas violentamente, como hasta entonces ocurría, o en el mejor de los casos, tratarse como asuntos que jurídicamente debían atenderse con los expedientes, procedimientos y mecanismos del derecho penal o civil tradicional.

El Estado, como lo señaló Louis Blanc, debía intervenir activamente en la vida económica para lograr la justicia social en beneficio de todos y no sólo de la burguesía. Por ello, era preciso pensar en ministerios gubernamentales nuevos como el del progreso, y también, crear talleres en el ámbito industrial. ${ }^{131}$ El Estado capitalista podía desaparecer, como sostenía Marx, si no se realizaban con urgencia los ajustes sociales por la vía pacífica y democrática. Según Blanc, la transformación social requería de la iniciativa privada, y para ese efecto, era conveniente crear un banco nacional y un sistema de crédito accesible a los emprendedores; por su parte, el Estado debía mantener el control sobre los ferrocarriles, la minería o los seguros.

Autores de distintos orígenes, como Lorenz von Stein, aludían a mediados del siglo XIX, a un Estado liberal que adoptara contenidos sociales con el fin de evitar la revolución de las masas. ${ }^{132}$ Las reformas sociales no eran una cuestión que dependiera sólo de la ética, sino de la necesidad histórica y del desarrollo del capitalismo. La integración entre las diversas clases debía realizarse para mantener el sistema capitalista y el derecho de propiedad. El Estado tenía que ser un instrumento de las clases trabajadoras y no un instrumento exclusivo de la burguesía.

La conciencia social, económica y política exigía cambios que lograran conciliar la libertad con la igualdad. Tanto la socialdemocracia alemana

131 Abendroth, Wolfgang, "El Estado de derecho democrático y social como proyecto político", en Abendroth, Wolfgang et al., El Estado social, Madrid, Centro de Estudios Constitucionales, 1986, p. 15.

132 Sotelos, Ignacio, El Estado social. Antecedentes..., op. cit., pp. 119-126. 
Este libro forma parte del acervo de la Biblioteca Jurídica Virtual del Instituto de Investigaciones Jurídicas de la UNAM

como los fabianos ingleses apostaban en el mismo sentido. Hasta la Iglesia católica, en la famosa encíclica Rerum Novarum de 1891, se pronunciaba por las reformas sociales para lograr la integración y armonía entre las clases. De esta forma, a partir de los años ochenta del siglo XIX, se fue formando en muchos países europeos una estructura estatal y social caracterizada por su renuncia al libre comercio irrestricto, porque los que concurrían al mercado no estaban en condiciones simétricas. Una nueva visión del Estado se abría camino, aunque aún pervivían por esos años, muchos de los elementos elitistas del viejo Estado liberal de derecho. ${ }^{133}$

133 Harris, David, La justificación del Estado del bienestar, Madrid, Instituto de Estudios Fiscales, 1990 . 
Este libro forma parte del acervo de la Biblioteca Jurídica Virtual del Instituto de Investigaciones Jurídicas de la UNAM

\section{Capítulo TerGero}

\section{EL ESTADO DEL BIENESTAR}

\section{INTRODUCGIÓN}

Lo que hoy llamamos el Estado social, Estado social y democrático de derecho, Walfare State o Estado del bienestar, comprende al menos tres periodos distinguibles: el primero abarca desde los años ochenta del siglo XIX hasta el inicio de la Primera Guerra Mundial, en donde el Estado social es meramente asistencial y no concibe a los derechos económicos, sociales y culturales como derechos humanos; el segundo se extiende por el periodo de entreguerras, integra las dos conflagraciones mundiales y concluye con el fin de la Segunda Guerra Mundial y se caracteriza por constitucionalizar derechos sociales y por establecer las bases de la teoría económica para construir un Estado del Bienestar, y el tercero, que va de 1945 al final de los años setenta del siglo $\mathrm{XX},{ }^{134}$ en donde en los países más industrializados del mundo se materializa y consolida el Estado del bienestar. Tanto el Estado social como posteriormente el Estado del bienestar fueron modelos de Estado dominantes en muchos de los países europeos, en algunos americanos, y tuvo incidencia en otras regiones del mundo como en América Latina, aunque con características y niveles de profundidad muy distintos, dependiendo del nivel de industrialización y de las características más democráticas o autoritarias de cada nación.

La noción de Estado social no es fácilmente asible y depende del momento histórico y geográfico concreto en donde se analice - no es lo mismo Estado social que Estado del bienestar-. Pero en términos generales, podemos decir que fue el modelo de Estado que los países industrializados prefirieron a finales del siglo XIX y en buena parte del siglo XX, que implicaba una estructura de poder político en donde el Estado mediaba e intervenía en las relaciones de producción entre capitalistas y clases obreras. El Estado social no mantuvo la separación de esferas entre economía

134 Esta periodización se debe a Sotelo, Ignacio, El Estado social. Antecedentes, origen, desarrollo y declive, op. cit., p. 160. 
Este libro forma parte del acervo de la Biblioteca Jurídica Virtual del Instituto de Investigaciones Jurídicas de la UNAM

y sociedad como en el Estado liberal de derecho ni promovió la abstención del Estado en la economía, sino que, por el contrario, intervino en la economía con varios propósitos: corregir las deficiencias inherentes al mercado, y principalmente, paliar o reducir las desigualdades sociales que habían resultado de la aplicación del modelo de Estado liberal de derecho. Por eso, destacadamente, el Estado social en su vertiente fundamental de Estado del bienestar está vinculado a la existencia de sistemas de seguridad social con garantía y coadministración estatal, que tienden hacia la disminución de los riesgos sociales de los asalariados y hacia una garantía de un mínimo nivel de vida - los derechos económicos, sociales y culturales son concebidos como auténticos derechos fundamentales y la teoría económica justifica la intervención del Estado en la economía - En ese sentido, y a diferencia del Estado social, el Estado del bienestar está relacionado con el reconocimiento y garantía de los derechos económicos, sociales y culturales en las Cartas constitucionales y en diversas disposiciones jurídicas, con formas de organización democrática menos elitistas que las del Estado liberal de derecho, con una mayor participación de las clases desposeídas en los asuntos públicos, y en algunas de sus vertientes, se intentó la construcción de un socialismo democrático. ${ }^{135}$ Sus detractores, sobre todo en las etapas finales del mismo, lo asocian, entre otras, con: la crisis fiscal y de legitimidad del Estado, el incremento de la burocracia que atendía los derechos sociales y servicios públicos con el excesivo y arbitrario gasto público, con políticas clientelares y hasta populistas, y con formas de corrupción política y económica que provocaron el endeudamiento público en muchos países y el derroche de los recursos presupuestales.

Como dice Abendroth, la fórmula del Estado democrático y social tiene su propia historia. Apareció por primera vez en la Revolución de París de 1848 derivada de un compromiso entre los pequeños partidos demoliberales y las primeras asociaciones del movimiento obrero francés. Louis Blanc le dio un contenido concreto referido al derecho al trabajo, que comenzó a partir de entonces a entenderse como un derecho fundamental, y a la creación de centros de producción administrados por los trabajadores - cooperativas - en concurrencia con los empresarios privados. Blanc tomó, a su vez, el contenido de sus propuestas de Robert Owen, el que había aludido a esos elementos en los inicios del movimiento obrero inglés. Posteriormente la fórmula Estado democrático y social fue retomada por los partidarios de Lasalle, por los socialdemócratas alemanes y también por los europeos. Fi-

135 Sobre las diferencias entre Estado social y Estado del bienestar Luhmann, Niklas, Teoría política en el Estado de bienestar, Madrid, Alianza Editorial, 1993, pp. 31-39. 
Este libro forma parte del acervo de la Biblioteca Jurídica Virtual del Instituto de Investigaciones Jurídicas de la UNAM

nalmente, adquirió carta de nacimiento con las polémicas ideológicas entre marxistas y socialdemócratas de finales del siglo XIX y durante el XX, con diversas acepciones se introdujo en la legislación secundaria y en las Constituciones. ${ }^{136}$

Debe advertirse que las fórmulas jurídicas sobre el Estado social y democrático de derecho pueden ser más o menos retóricas y más o menos auténticas, todo dependerá de la manera y profundidad en la que se haya organizado efectivamente la sociedad en cualquiera de los Estados en donde esa fórmula o sus nociones se implantaron. Por eso, vale decir, que las categorías políticas y jurídicas, sólo adquieren significado cuando sus fines y valores efectivamente se realizan al interior de una sociedad. Con mucha seguridad lo señalo, la denominación Estado social y posteriormente Estado del bienestar, no tiene la misma trascendencia en México que en los países escandinavos.

\section{LOS INICIOS DEL ESTADO SOCIAL}

Los inicios de lo que se denomina Estado Social tienen que ver con las pugnas entre socialdemócratas y marxistas, sobre todo en la Europa central, y con las necesidades del propio sistema capitalista, para ajustarse a las nuevas realidades a finales del siglo XIX. El conflicto entre marxistas y socialdemócratas está vinculado a la manera de entender el papel del Estado. Los marxistas sostenían invariablemente el carácter de clase del Estado y su instrumentalización al servicio del capital, mientras que los socialdemócratas consideraban que el Estado podía ponerse también al servicio de la clase trabajadora siempre y cuando éstos lograran el sufragio universal. Si los trabajadores tenían acceso al sufragio universal era cuestión de tiempo llevar adelante las reformas sociales y económicas que requiriesen.

En 1875, el Congreso de Gotha, que da lugar al Partido Socialdemócrata Alemán, propone las bases de lo que más tarde sería el Estado Social. Se reivindica el sufragio universal para todos los mayores de veinte años; se propone derogar todas las leyes que limiten la libertad de expresión, manifestación y reunión; se demanda educación pública obligatoria en todos los niveles; se insiste que los asuntos de la religión son de la esfera privada de las personas; se pide un impuesto progresivo sobre la renta que sustituya a los impuestos indirectos; se reclama una jornada de trabajo asequible a las

136 Abendroth, Wolfgang, "El Estado de derecho democrático y social como proyecto político", op. cit., pp. 15-17. 
Este libro forma parte del acervo de la Biblioteca Jurídica Virtual del Instituto de Investigaciones Jurídicas de la UNAM

necesidades de la sociedad; se exige el fin del trabajo infantil y el que resulte nocivo a las mujeres; se quieren leyes protectoras de la vida y la salud de los trabajadores, y se plantean medidas de inspección de minas, fábricas y talleres por inspectores elegidos por los trabajadores.

Estas demandas obreras, que eran cada vez más crecientes y que querían cambiar la situación a través de la legalidad, encontraron campo fértil en los gobiernos liberales y conservadores de la época porque las clases dirigentes tenían pavor a la inminente revolución socialista, y porque al ampliarse el sufragio universal, era indispensable apoderarse del discurso de la socialdemocracia para lograr los respaldos electorales necesarios. Bismarck, aplicando la política del palo y la zanahoria, promovió en 1878 leyes antisocialistas para ilegalizar al Partido Socialdemócrata Alemán, pero al mismo tiempo, permitió al grupo parlamentario socialdemócrata en el Parlamento. En 1881 anuncia el proyecto de un Estado social, y a partir de 1883 promueve leyes que contemplan: el seguro de enfermedad obligatorio para los obreros, financiado en parte por ellos, pero obligatorio; el seguro de accidentes de trabajo — 1884 — ; en 1889, el seguro de invalidez, y en 1891, el de vejez al cumplir 70 años.

En Gran Bretaña, el Estado social se instaura en 1911 con la National Insurance Act, que fue una medida del gobierno del partido liberal por la rápida expansión en esos años de la miseria provocada por el desempleo. La seguridad social inglesa tenía una diferencia con la alemana, pues el Estado británico participaba más en los costos de la misma, y además, se vinculaba al impuesto sobre la renta que había sido establecido en 1909. La seguridad social inglesa ocurre a la par que otros acontecimientos: en 1905 se aprueba la Unemployed Workmen Act que diseñaba una política contra el desempleo a través de la promoción de obras públicas de emergencia, y en 1908, los mineros consiguen una jornada laboral de ocho horas y un salario mínimo.

\section{EL ESTADO SOCIAL EN EL PERIODO DE ENTREGUERRAS Y DURANTE LAS CONFLAGRACIONES MUNDIALES. HAGIA LA GONSTRUCGIÓN DEL ESTADO DEL BIENESTAR}

La implantación del Estado social, embrión del Estado del bienestar, no tuvo su origen en los partidos socialistas sino en los partidos conservadores y liberales. Este hecho histórico va a ser muy importante porque más adelante señalaremos los limitados alcances del Estado social. El antecedente también es relevante porque existen diversos tipos de esta forma de Estado, algunos 
Este libro forma parte del acervo de la Biblioteca Jurídica Virtual del Instituto de Investigaciones Jurídicas de la UNAM

más avanzados que otros. Adicionalmente, esa circunstancia histórica nos permite distinguir, como hacen algunos teóricos, que el Estado del bienestar, ahí donde se dio, implicó una forma o modalidad desarrollada y calificada del Estado social. ${ }^{137}$

Para los partidos conservadores y liberales de fines del siglo XIX y principios del XX, era muy importante detener cualquier atisbo revolucionario en sus sociedades, y contener desde los gobiernos, el avance electoral de la socialdemocracia arrebatándole algunas de sus banderas. Al empezar la Primera Guerra Mundial, los gobiernos en confrontación buscaron para sus propósitos bélicos ganarse las simpatías del movimiento obrero de los respectivos países y, con ese fin, reconocieron derechos a los sindicatos y a los trabajadores a cambio de que éstos respaldaran los esfuerzos militares.

Según Ignacio Sotelo, la Primera Guerra Mundial aportó al Estado social las siguientes cuatro contribuciones: 1) los Estados europeos adquirieron, debido a las circunstancias de la guerra, la obligación de intervenir como mediadores entre los intereses de los empresarios y los obreros para detener las huelgas, y entre otras cosas, reconocieron en la mayoría de los países el sufragio universal para congraciarse con la clase trabajadora; 2) la economía de guerra fortaleció la capacidad del Estado para intervenir en la economía, y en grados diversos, el liberalismo económico fue desplazado por una economía mixta que servirá después para edificar el Estado del bienestar; 3) con la guerra, la mujer se incorporó al trabajo, hecho que marcó el incremento de sus derechos políticos y que significó el debilitamiento de la posición del varón en la familia y en la sociedad, y 4) el triunfo de la revolución bolchevique de 1917 y el establecimiento del Estado soviético que se industrializaba rápidamente mediante la planificación central, implicó para el mundo entero una alternativa al Estado capitalista, lo que acicateó en los demás Estados la necesidad de ampliar los niveles de Estado social. ${ }^{138}$

Al final de la Primera Guerra Mundial los anteriores rasgos no sólo no desaparecieron, sino que se mantuvieron. En distintos países europeos, en los Estados Unidos y Canadá, se aprobaron numerosas normas de carácter social y se elevó a rango de ley lo que había sido práctica en la contienda mundial. En otros países y por razones históricas distintas, como sabemos

137 Aunque muchos teóricos del Estado del bienestar asumieron sus deficiencias y exigieron amplios debates para que éste no condujera a un estatismo siervo del poder político o capitalista. Además, pidieron que el Estado del bienestar desmercantilizara no sólo las relaciones de producción, sino la totalidad de las relaciones humanas. Offe, Claus, Contradicciones en el Estado del bienestar, Madrid, Alianza Editorial, 1990.

138 Sotelo, Ignacio, El Estado social. Antecedentes, origen, desarrollo y declive, op. cit., pp. 183-190. 
Este libro forma parte del acervo de la Biblioteca Jurídica Virtual del Instituto de Investigaciones Jurídicas de la UNAM

los mexicanos, la Constitución de Querétaro de 1917, reconoce en su texto constitucional, derivados de la Revolución y por primera vez en la historia de la humanidad, los derechos sociales a la educación, a la propiedad socialcolectiva, al trabajo y a la seguridad social en los artículos 3o., 27 y 123. El Estado social mexicano sin lugar a dudas existió - más problemático es sostener si tuvimos Estado de bienestar - después de la Revolución, con distintos niveles de profundidad, dependiendo de las características de cada sexenio de gobierno. La diferencia fundamental del Estado social mexicano con otros Estados sociales del mundo, se desprende del carácter autoritario y muchas veces corrupto del régimen político que lo administró hasta principios de la década de los ochenta del siglo XX.

En Alemania, el título V - artículos 151 a 165- de la Constitución de Weimar de 1919, incorporó la noción de justicia social y fija los principios de lo que se denominó el Estado del bienestar. ${ }^{139}$ Éste es cualitativamente superior al Estado social porque en el último, sus elementos constitutivos consisten en garantizar a los trabajadores un mínimo de seguridad en caso de enfermedad, accidente, invalidez y vejez, sin por ello modificar, cuestionar o trastocar las relaciones capitalistas de producción; esto es, se admiten medidas de previsión social pero no auténticos derechos fundamentales y se deja que la vida económica se desenvuelva libremente - el Estado interviene al final de los procesos capitalistas para paliar las deficiencias del mercado - En cambio, en el Estado del bienestar, el orden de la vida económica tiene que coincidir con los principios de justicia con el fin de que se proporcione una existencia para todos de acuerdo con la dignidad humana, tal como reza el artículo 151 de la Constitución de Weimar. Es decir, en el Estado del bienestar se asume que son necesarias reformas sustanciales a las relaciones capitalistas de producción para lograr garantizar la dignidad humana, y por tanto, el Estado debe intervenir en la economía desde sus primeras etapas para remodelar el orden socioeconómico con fundamento en los derechos económicos, sociales y culturales, así como en los principios de justicia social para que éstos sean alcanzados. ${ }^{140}$

A diferencia de las Constituciones contemporáneas, por ejemplo de la reforma de 2011 al artículo 1o. de la Constitución mexicana de 1917, en donde la dignidad humana se introduce al inicio del texto constitucional - párrafo final del primer precepto - como valor supremo del ordena-

139 Forsthoff, Ernst, "Problemas constitucionales del Estado social", en Abendroth, Wolfgang et al., El Estado social, op. cit., pp. 45-67.

140 Sotelo, Ignacio, El Estado social. Antecedentes, origen, desarrollo y declive, op. cit., pp. 197 у 199 . 
Este libro forma parte del acervo de la Biblioteca Jurídica Virtual del Instituto de Investigaciones Jurídicas de la UNAM

miento, la Constitución de Weimar, colocó a la dignidad humana dentro de los principios de la vida económica para no desprenderla de las relaciones de la producción económica. Con ello, ese texto constitucional quería significar que la dignidad humana no puede concebirse en un orden socioeconómico injusto y, por ello, el Estado debía intervenir en la producción y distribución de la riqueza. Los derechos económicos, sociales y culturales son auténticos derechos humanos y no meras medidas de previsión social de carácter asistencial.

Los derechos sociales y económicos que reconoció la Constitución de Weimar, como el derecho al trabajo, cuestionan que el trabajo sea una simple mercancía porque esa consideración colisionaría directamente con la dignidad humana. El trabajo, según ese texto constitucional, es un derecho y un deber que informa a toda la Constitución y a la vida económica y social. Además, el Estado del bienestar en la Constitución alemana de 1919 asume y reconoce los siguientes principios y derechos: el carácter social de la propiedad; la socialización de las empresas privadas cuando ello resulte en beneficio del bien común; la constitucionalización de un sector público de la economía; el reconocimiento amplio a todas las formas de organización sindical y al ejercicio de sus derechos; la maximización de los derechos a la seguridad social; la negociación colectiva de las condiciones de trabajo; la cogestión en las empresas; y, las ayudas a la manutención de los trabajadores y sus familias cuando el salario fuese insuficiente, entre otros. El objetivo del Estado del bienestar alemán consistía en garantizar y posibilitar todos los derechos anteriores. Como demostrará la teoría económica posterior, la Constitución de Weimar fracasó en este cometido porque antes del ascenso del nazismo, no propició un esquema de pleno empleo para que pudiera costear íntegramente los derechos del nuevo Estado.

En la Gran Bretaña, la Primera Guerra Mundial también significó para el futuro Estado del bienestar el reconocimiento de muchos derechos económicos y sociales, tales como los derechos a la salud, a la educación y la extensión de los derechos a la seguridad social. El mayor aporte británico, con sus correspondientes matices a la construcción del Estado del bienestar, es el seguro de desempleo. La Unemployment Insurance Act de 1920 amplió, respecto a leyes previas, los beneficios del mismo a todos los trabajadores con un salario anual de 250 libras. Más tarde, en 1924, retrocedió el sistema de seguro de desempleo para que los costos del mismo no sólo fueran cubiertos por la hacienda pública, sino también por los obreros y empresarios. En 1934, se distinguió entre el seguro de desempleo, que era tripartitamente sufragado, de las ayudas sociales pagadas íntegramente con fondos públicos 
Este libro forma parte del acervo de la Biblioteca Jurídica Virtual del Instituto de Investigaciones Jurídicas de la UNAM

y que se destinaban a personas que no tenían otro medio de vida - en esa época se estimaba que en Gran Bretaña había más de un millón de personas en esas condiciones-.

Cada país europeo, principalmente los escandinavos y los del norte del continente, fue edificando su Estado del bienestar bajo condiciones propias. El modelo sueco, por ejemplo, se desarrolla en 1917 a partir del reconocimiento del sufragio universal para hombres y mujeres mayores de 18 años. ${ }^{141}$ Antes que lo propusiera Keynes, durante la Gran Depresión, los gobiernos socialdemócratas suecos impulsaron una política de obras públicas y de inversiones estatales para superar la crisis y mejorar las condiciones de empleo y salariales, lo que consiguieron a finales de la década de los años treinta, en donde llegaron a alcanzar el pleno empleo. El modelo sueco se basó: en la economía mixta, en la fortaleza de los sindicatos, en la cogestión en las empresas, en la creación de múltiples sociedades cooperativas diseñadas y dirigidas por los trabajadores y, fundamentalmente, en una política fiscal de altos impuestos de carácter progresivo, que hizo posible que se llevara a cabo una política social para posibilitar derechos económicos y sociales muy costosa, que fue digna del Estado del bienestar que construyeron.

La teoría económica posterior a la Primera Guerra Mundial puso en evidencia dos cuestiones fundamentales: las guerras al igual que la paz, no se ganaban sin una fuerte intervención del Estado en la economía - el Estado no podía ser más un espectador de las relaciones económicas-, y el desempleo, que se extendió por todos los países, debía ser solucionado con otras visiones económicas distintas a las de la economía liberal o clásica no había capacidad para ofrecer trabajo a todos los que regresaron de la primera guerra - En 1929, se produjo el derrumbe de la bolsa de Nueva York, y a finales de 1930, el incremento del desempleo era abrumador en los países europeos y en los Estados Unidos - la crisis económica parecía no tener solución-. De esta suerte, los economistas de la época advirtieron que para la construcción del Estado del bienestar era necesario lograr el pleno empleo mediante la activa intervención económica del Estado.

Dos fueron los economistas que sentaron las bases teóricas de la economía del Estado del bienestar: John Maynard Keynes y William Beveridge. El primero, dio un giro a la economía clásica e insistió en la crítica a la economía del laissez-faire; puso en cuestión la idea dominante de que el ahorro

141 Sobre los cambios legales en el sistema electoral y su impacto en la construcción de la democracia y del Estado del bienestar en Suecia debe verse la obra clásica de Rustow, Danwart A., The Politics of Compromise. A Study of Parties and Cabinet Government in Sweden, Princeton, Nueva Jersey, Princeton University Press, 1955. 
Este libro forma parte del acervo de la Biblioteca Jurídica Virtual del Instituto de Investigaciones Jurídicas de la UNAM

produce inversión; abundó en la idea de la utilización óptima de todos los recursos disponibles en una economía, y enfatizó la necesidad de una política monetaria que estableciera el tipo de interés adecuado para mantener niveles de empleo que llegaran a la plena ocupación. El segundo, propuso en 1941 un informe al gobierno británico que describe los contenidos del Estado del bienestar. ${ }^{142}$

Keynes desmintió que el mercado, por sí mismo, consiguiera el equilibrio entre la oferta y la demanda y, eso es así, porque cuando se cambian productos por dinero desaparece la comunicación directa entre comprador y vendedor, dado que el vendedor con su dinero, derivado de la venta, puede hacer lo que quiera: ahorrarlo, volverlo a invertir en ese mercado o gastarlo en otro. Lo anterior significa que el interés individual no coincide con el interés social y que la racionalidad del homo oeconomicus es un mito sin fundamento - ambas eran premisas de la economía clásica - El Estado debe intervenir para corregir las imperfecciones de la economía de mercado, y según Keynes, lo debe hacer en aquellos ámbitos que quedan fuera de la actividad económica individual o en momentos de crisis o recesión económica. ${ }^{143}$

La crítica de Keynes se dirige a la teoría económica clásica porque ésta estimaba que para resolver el problema del desempleo se debían reducir los salarios de los trabajadores y los precios de los productos con el fin de que los empresarios invirtieran. Keynes desvincula el ahorro de la inversión porque los ahorros no están ahí para ser invertidos mecánicamente y, como ya se dijo, se pueden mantener en el ahorro, se pueden gastar o se pueden utilizar en otros mercados. La reducción de los salarios a los trabajadores no es estímulo suficiente para que los empresarios inviertan, pues esa hipótesis sólo funciona respecto a casos concretos pero no en relación con la totalidad del sistema económico. Keynes propone generar condiciones de confianza en la economía en general, tanto acerca de la demanda como de la oferta, para que los empresarios destinen sus ahorros a la inversión. Sin esa confianza por parte de los empresarios y que en buena medida es responsabilidad del Estado, no existirían las condiciones plausibles de inversión.

Para Keynes, debe existir ocupación plena de recursos que entraña que para disminuir el desempleo tiene que aumentar la demanda global de productos, lo que a su vez depende del consumo y de la inversión global. Ésta última no es responsabilidad sólo de los empresarios, porque éstos pueden

142 Keynes, John Maynard, Teoría general de la ocupación, el interés y el dinero, México, Fondo de Cultura Económica, 1965, y Beveridge, William, Seguridad social y servicios afines. Las bases de la seguridad social, México, Fondo de Cultura Económica, 1946.

143 Keynes, John Maynard, Teoría general de la ocupación, el interés y el dinero, op. cit., p. 333. 
Este libro forma parte del acervo de la Biblioteca Jurídica Virtual del Instituto de Investigaciones Jurídicas de la UNAM

preferir ahorrar a invertir, y por eso, el Estado debe ser el catalizador de la inversión en momentos de crisis o recesión. Si el Estado invierte promueve el empleo, éste a su vez, incentiva el consumo y, despierta el interés de los empresarios particulares en maximizar sus ganancias mediante nuevas inversiones. Se produce con ello un efecto multiplicador sobre todos los recursos y elementos de la economía.

En cuanto al tipo de interés, Keynes lo considera clave para mantener la inversión privada. Si los tipos de interés son bajos se estimula la inversión, si por el contrario son altos, se promueve el ahorro. En consecuencia, es necesario que los bancos centrales tengan a su cargo la política monetaria y puedan ejercer control y vigilancia sobre ella. Lo importante para el logro del pleno empleo es mantener muy alta la inversión. Por eso, en momentos de dificultades económicas, el Estado no pude ni debe contener el gasto público. Sin embargo, Keynes era muy consciente de la incapacidad de la economía capitalista para ofrecer empleo a todos y, también asume, que ese modelo económico distribuye de manera desigual y arbitraria la riqueza. ${ }^{144}$ La solución que llega a proponer para el problema del pleno empleo es la socialización de las inversiones, pero este camino es incompatible con la economía capitalista, que concede prevalencia al empresario privado en el campo de la inversión. También era defensor del proteccionismo para enfrentar los riesgos de la globalización económica que, desde su perspectiva, generaba asimetrías de competencia en el mercado interno. La globalización económica alteraba las premisas de su teoría.

Keynes nunca fue partidario del colectivismo o del modelo soviético. El propósito de la teoría keynesiana es conservar el capitalismo, aunque propone eliminar sus peores defectos que, desde su punto de vista, son: el capital financiero, la especulación, y el rentismo. Esas variables constituían, a su juicio, un cáncer que atacaba los cimientos para el funcionamiento de un capitalismo funcional y adecuado y que además incidían en el logro del Estado del bienestar. ${ }^{145}$

En cuanto al informe Beveridge de 1941, éste señala que el objetivo de la seguridad social es garantizar a todos y en cualquier circunstancia un subsidio que asegure una vida digna. El modelo británico de seguridad social de esa época no ofrecía servicios médicos satisfactorios y los trabajadores autónomos carecían de atención. Para Beveridge, la seguridad social es el aspecto más importante del progreso social y sus objetivos son elimi-

144 Ibidem, p. 328.

145 Dillard, Dudley, La teoría económica de Fohn Maynard Keynes. Teoría de una economía monetaria, Madrid, Editorial Aguilar, 1981, p. 342. 
Este libro forma parte del acervo de la Biblioteca Jurídica Virtual del Instituto de Investigaciones Jurídicas de la UNAM

nar la miseria, la enfermedad, el desamparo, la ignorancia y el desempleo. El costo de la seguridad social debe recaer tanto en el Estado como en los empresarios y trabajadores y, al organizarla, el Estado ha de tener cuidado en no debilitar la iniciativa ni la responsabilidad individual para que no se incentive lo que hoy llamamos paternalismo estatal.

Las principales propuestas del informe Beveridge son las siguientes:

1) La seguridad social ha de llegar a todos los ciudadanos y cubrir todos los posibles sucesos que lleven a una diminución o pérdida del ingreso por enfermedad, accidente, invalidez, desempleo o vejez. No obstante la universalidad de la medida, el informe distingue trato diferenciado para los siguientes grupos: asalariados con un puesto de trabajo; a) trabajadores autónomos; b) amas de casa en edad de trabajar; c) desempleados; d) niños y jóvenes que no han llegado a la edad de trabajar, y e) personas que han sobrepasado la edad legal para trabajar. 2) La seguridad social ha de ser financiada por los trabajadores, patrones y el Estado, aunque en los casos de necesidad quepan ayudas fiscales directas. 3) La seguridad social debe garantizar en todas las circunstancias y para todos unos ingresos mínimos que permitan vivir dignamente. ${ }^{146}$

La realización de las propuestas anteriores exigió la reordenación de la administración pública británica. El informe considera la creación de un Ministerio de Seguridad Social y otro de Salud. El acento se pone en la salud corporal y en el desarrollo intelectual de la población — salud y educación-. Además, se estima que las familias sean subvencionadas con cargo al Estado en proporción al número de hijos. Se recomienda, igualmente, ampliar los servicios médicos para incluir la medicina preventiva y la rehabilitación. Lo más importante, no obstante, es poner en marcha políticas de mantenimiento del pleno empleo. El informe insiste en que no cabe un modelo satisfactorio de seguridad social sin pleno empleo y llega a indicar que no se puede tolerar para el mantenimiento del nuevo modelo más de un $3 \%$ de desempleados.

William Beveridge era, en el fondo, un conservador que quería que los aventajados de la sociedad capitalista mantuvieran sus posiciones de privilegio. Era consciente que ese objetivo sólo se podría lograr en una sociedad en la que nadie padeciera miseria o inseguridad. Para él, la política de empleo no requiere per se de la socialización de la industria, pero sí de la efectiva

${ }^{146}$ Beveridge, William, Seguridad social y servicios afines. Las bases de la seguridad social, op. cit. 
Este libro forma parte del acervo de la Biblioteca Jurídica Virtual del Instituto de Investigaciones Jurídicas de la UNAM

subordinación de la inversión privada a la política pública. ${ }^{147}$ Su informe tuvo un enorme éxito y acogida en Gran Bretaña, y fue seguido por muchos países europeos, principalmente del centro y del norte. Bien se puede decir, que el informe de Beveridge entrañó la concreción de políticas públicas que permitieron, durante décadas, consolidar el Estado del bienestar en Europa.

En los Estados Unidos, el New Deal, promovido por Franklin Delano Roosevelt, amplió, sobre todo a partir de 1935, el Estado del bienestar norteamericano. En ese año, la Corte Suprema de los Estados Unidos declaró inconstitucional la National Recovery Act, lo que obligó al presidente de los Estados Unidos a imprimir un giro más radical a la política del New Deal. En ese país, en 1936, se estableció una comisión de conflictos colectivos y un sistema de seguridad social. ${ }^{148}$ Durante décadas, en América del Norte, desde los años treinta hasta la crisis del petróleo de 1973, se extendieron de manera consistente los márgenes del Estado del bienestar.

La Segunda Guerra Mundial, al igual que la primera, había enseñado a todos los gobiernos occidentales, a los capitalistas y a los sindicatos, que sólo promocionando los intereses comunes se favorecía a los propios y, no al revés, como sostuvieron los teóricos de la economía clásica. La abstención del Estado en la vida económica era insostenible porque conducía a la destrucción del propio Estado capitalista al acentuarse entre los distintos sectores de manera extrema las desigualdades económicas y sociales. El precio que había que pagar por la paz, entrañaba el establecimiento, en la segunda posguerra, de un Estado del bienestar que diera seguridades a través de derechos humanos de carácter social y económico, tanto a los privilegiados por el sistema capitalista como a los menos aventajados en él.

\section{El ESTADO DEL BIENESTAR DESPUÉS DE 1945}

La etapa de consolidación del Estado del bienestar ocurrió entre el final de la Segunda Guerra Mundial y los inicios de los años setenta del siglo XX. Cada país, dependiendo de la orientación política de los gobiernos, adoptó características diferenciadas. Por ejemplo, en Alemania y con mayor profundidad en Suecia, implicó no sólo desarrollar la seguridad social para garantizar a todos un mínimo vital, sino que se pretendió en algunos momentos realizar

147 Beveridge, William, Full Employment in a Free Society, Londres, Allen and Unwin, 1944, p. 261.

148 Blas Guerrero de, Andrés y García Cotarelo, Ramón, Teoría del Estado, Madrid, Universidad Nacional de Educación a Distancia, 1988, pp. 108 y 109. 
Este libro forma parte del acervo de la Biblioteca Jurídica Virtual del Instituto de Investigaciones Jurídicas de la UNAM

la igualdad social y avanzar hacia un socialismo democrático. En Gran Bretaña y en los Estados Unidos, nunca existió esa pretensión. Salvo posiciones extremas, en esas naciones nunca se buscó modificar la estructura social ni eliminar de fondo las diferencias de clases ni cambiar el sistema capitalista, lo que se quería era impedir una revolución social que pusiera en riesgo el modo de producción del capitalismo.

En Gran Bretaña el Estado del bienestar fue construido por los laboristas y los conservadores. Los laboristas lo iniciaron y los conservadores lo consolidaron por razones electorales. El Estado del bienestar era exigido por muchos sectores sociales, y ningún partido quería desencantar a la sociedad, privándola de sus beneficios. Todos apostaron, con algunos matices, por el Estado del bienestar. Durante estos años se redujo la desigualdad social en la Gran Bretaña y muchos sectores sociales que antes no tenían acceso a la educación y a la salud obtuvieron la garantía de esos derechos fundamentales. El Estado del bienestar británico puede ser juzgado a distancia por su mayor o menor eficiencia y por el incremento de la burocracia que generó. De 1966 a 1976, la burocracia estatal representaba a 3.3 millones de empleados de gobierno, lo que significaba el $13.2 \%$ de la fuerza de trabajo ocupada. ${ }^{149}$

Los laboristas británicos tuvieron claro que el pleno empleo demandaba una capacidad expansiva del consumo, lo que a su vez exigía salarios altos en continuo aumento y servicios sociales eficientes. Era necesario para lograr lo anterior, que el banco de Inglaterra fuese público, que se realizarán los derechos a la educación y a la salud y que las empresas energéticas pasasen al sector público al igual que las empresas de transporte interno, incluyendo a los ferrocarriles; además de que se debía impulsar la nacionalización de los sectores del hierro y del acero, porque en ellos predominaban monopolios privados, que habían impuesto precios muy elevados a la economía. Las medidas expuestas se debían complementar con un acceso a la salud gratuito - el Servicio Nacional de Salud - para evitar que el dinero de cada quien proporcionara mejores cuidados médicos.

En el caso de los conservadores británicos, cuando les tocó gobernar, mantuvieron en líneas generales las políticas sociales de los laboristas, con ciertas distinciones. Por ejemplo, en el terreno de las nacionalizaciones, no continuaron con ellas y sólo revirtieron la nacionalización de la industria del hierro y el acero. Los conservadores se cuidaron mucho de no retro-

${ }^{149}$ Lo anterior sirvió de crítica y de justificación al Partido Conservador de la época de Margaret Thatcher para desmontar en parte el Estado del bienestar británico. Sotelo, Ignacio, El Estado social. Antecedentes, origen, desarrollo y declive, op. cit., p. 270. 
Este libro forma parte del acervo de la Biblioteca Jurídica Virtual del Instituto de Investigaciones Jurídicas de la UNAM

ceder en la implementación del Estado del bienestar porque sabían de las consecuencias electorales que ello tendría para su causa. En algunos casos, los gobiernos conservadores llegaron a gastar más que los laboristas en algunos servicios sociales. En el ámbito ideológico, los conservadores británicos oponían el principio de igualdad de oportunidades al principio de igualdad social de los laboristas. Se trataba de un énfasis importante, porque la igualdad de oportunidades legitima las desigualdades resultantes de los procesos económicos y sociales. Para los años setentas del siglo XX, los laboristas fueron plegándose al principio que habían enarbolado los conservadores.

La situación de la Alemania Federal en la segunda posguerra demandó la intervención del Estado para impedir el desempleo masivo y también exigió algunos niveles de planificación estatal para aumentar la capacidad de compra de los distintos sectores sociales, lo que iba de la mano con la inversión pública y privada, el aumento de la producción, y la redistribución de la renta. Los Partidos de la Unión (CDU/CSU) o los cristianodemócratas imponen al finalizar la guerra la economía social de mercado para mantener el sistema capitalista, pero al mismo tiempo para garantizar ciertos derechos sociales que evitaran la desestabilización política y económica. Al Partido Social Demócrata (SPD), a los socialdemócratas cuando gobernaron, no les quedó más remedio que ajustarse a lo que habían empezado los cristianodemócratas. Ello significó integrar a la clase obrera en el capitalismo realmente existente. Lo importante era que se pagara lo que era justo al asalariado, en un contexto que se quería de pleno empleo, porque éste equilibraba la relación de fuerzas entre trabajadores y empresarios. Los socialdemócratas alemanes concibieron un socialismo sui generis, que por un lado, rechazaba el liberalismo económico por sus crisis cíclicas y el aumento del desempleo y su tendencia a la baja en los salarios; pero también se opusieron a la economía plenamente planificada, por aducir que era ineficiente y por estimar que suprimía o limitaba las libertades y los derechos fundamentales.

El 24 de junio de 1954, el Tribunal Federal Contencioso Administrativo de Alemania, reconoce el derecho de todo ciudadano a reclamar al Estado una ayuda de supervivencia o mínimo vital. El basamento jurídico de la resolución consistió en apelar a la Ley Fundamental de 1949, en concreto al principio de dignidad humana, al derecho humano al libre desarrollo de la personalidad, y al principio de Estado democrático social de derecho. Más tarde, se aprobó la Ley Federal de Ayuda Social que entró en vigor el 1o. de junio de 1962 y que garantizaba a todo ciudadano una subsistencia digna.

La República Federal de Alemania se esmeró por reconocer y garantizar la seguridad social a los habitantes de ese país, así como los derechos 
Este libro forma parte del acervo de la Biblioteca Jurídica Virtual del Instituto de Investigaciones Jurídicas de la UNAM

humanos a la salud, a la educación, a las pensiones dinámicas y a la vivienda, además de compensar mediante indemnizaciones a las víctimas de las dos Guerras Mundiales. Este esfuerzo implicaba que el crecimiento económico antecediera al reparto social y significaba que la tarea principal era superar las crisis, controlando inflación y desempleo. Durante algunos gobiernos socialdemócratas, específicamente en el de Willy Brandt - 1973-, se intentó profundizar en el Estado del bienestar. Se procuró introducir la planificación económica en aras de alcanzar mayores niveles de igualdad social y de pleno empleo, en la línea de alcanzar una suerte de socialismo democrático en el sentido que había marcado el Programa de Bad Godesberg de 1959, en el que se había rechazado el marxismo, y en cambio, se había aludido al principio de "tanto mercado como sea posible pero tanta planificación como sea necesaria". Los gobiernos posteriores al de Brandt moderaron esas expectativas, y por razones que esgrimieron como económicas, sostuvieron que el Estado del bienestar había llegado a límites que no convenía traspasar: el costo del Estado del bienestar no podía resolverse acudiendo al déficit presupuestal, al estancamiento económico o al endeudamiento. A partir de 1982, con la llegada al poder de Helmut Kohl, se amplió el abandono del Estado del bienestar que se había defendido en épocas anteriores y comenzaron claramente a introducirse políticas económicas de corte neoliberal.

A mediados de los años setenta en algunos países, y en otros durante las dos décadas siguientes del siglo XX, el Estado del bienestar comenzó a ser desmantelado, tanto por la acción de algunos gobiernos, claramente los de Margaret Thatcher en Gran Bretaña y Ronald Reagan en los Estados Unidos, como por la recuperación de teorías económicas que volvían a los principios del liberalismo económico - Friedrich von Hayek, Ludwig von Mises y Milton Friedman- y que hoy conocemos como neoclásicas o neoliberales. La lucha en el mundo de las ideas y en el político se debatía, por un lado, en la aspiración de algunos sectores de la clase obrera y de los sectores desfavorecidos, que reclamaban la consolidación de un orden socioeconómico igualitario, ${ }^{150}$ y por otro, en el poder de las trasnacionales y de las grandes empresas nacionales que exigían que la economía de mercado - el capitalismo - siguiera confiriendo exclusivamente a los propietarios del capital el decidir cuánto, cómo y dónde invertir. Las ideas más radicales de Keynes: el proteccionismo para enfrentar los efectos de la globalización en el mercado interno y la socialización de las inversiones ${ }^{151}$ fueron aban-

150 Cabo Martín de, Carlos, La crisis del Estado social, Barcelona, PPU, 1986.

151 Keynes, John Maynard, Teoría general de la ocupación, el interés y el dinero, op. cit., p. 335. 
Este libro forma parte del acervo de la Biblioteca Jurídica Virtual del Instituto de Investigaciones Jurídicas de la UNAM

donadas a favor del libre comercio mundial sin cortapisas y por el empoderamiento de las grandes trasnacionales para definir la totalidad de las condiciones del mercado.

\section{LA CRISIS DEL ESTADO DEL BIENESTAR}

El desmoronamiento paulatino pero sostenido del Estado del bienestar ocurre cuando en los países industrializados se comienzan a sentir las contradicciones y deficiencias de este modelo de Estado. ${ }^{152}$ Podemos decir que esas causas son, entre otras, tanto económicas como políticas, sociales y jurídicas. ${ }^{153}$

Desde la economía se advirtió, en los años setenta del siglo XX, de la crisis del Estado del bienestar cuando el aumento del gasto público, para responder a las demandas y derechos sociales, era cada vez más alto, y las economías nacionales se vieron obligadas a recurrir al déficit presupuestal y al endeudamiento. La obra de James O'Connor sobre la crisis fiscal del Estado explica que el gasto público de los países industrializados se había incrementado considerablemente durante el siglo XX y que se dividía en: a) gastos de inversión social (obras de infraestructura que se requieren para la producción y acumulación del capital); b) gastos de consumo social (obras y servicios para socializar los costos del capital, como por ejemplo, el gasto del Estado para atender la contaminación ambiental o el gasto en educación y salud), y c) gasto social (obras y servicios que sirven para la legitimación del Estado, verbigracia, diversas ayudas sociales a los más necesitados que no están directamente, aunque sí indirectamente, vinculadas a las relaciones de producción). Estos gastos tenían un crecimiento constante y el Estado gastaba cada vez más de lo que ingresaba a sus arcas, lo que provocaba un déficit permanente y en aumento, que ponía en riesgo la viabilidad de la economía capitalista. La solución para superar la endémica crisis fiscal del Estado entrañaría el incremento de impuestos, pero esa salida podía conducir a la rebelión y resistencia de los contribuyentes. O'Connor analiza también como posibilidad la transición al socialismo, pero la descarta por las condiciones objetivas existentes en los Estados Unidos y prefiere apuntalar un modelo social-industrial que implicaba una versión teórica adaptada

152 Sobre el derecho y la economía del Estado del bienestar en crisis, Corcuera Atienza, Javier y García Herrera, Miguel Ángel, Derecho y economía en el Estado social, Madrid, Tecnos, 1988.

153 García Cotarelo, Ramón, Del Estado del bienestar al Estado del malestar, Madrid, Centro de Estudios Políticos y Constitucionales, 1986. 
Este libro forma parte del acervo de la Biblioteca Jurídica Virtual del Instituto de Investigaciones Jurídicas de la UNAM

al Estado del bienestar norteamericano de la época. ${ }^{154}$ Las soluciones a la crisis fiscal del Estado estarían, en diálogo con O'Connor, en: el incremento de los impuestos; el control de la política monetaria; la supervisión racional del gasto público para que éste sea más eficiente y eficaz, y al mismo tiempo, permita reducir la corrupción; la contención en el crecimiento de la estructura burocrática del Estado; la mayor participación de la sociedad en las decisiones públicas mediante instrumentos de democracia participativa y deliberativa, y en el control jurídico y político democrático de los grandes poderes fácticos económicos y mediáticos, tanto nacionales como trasnacionales.

Igualmente se requeriría para superar la endémica crisis fiscal del Estado reconocer que el Estado del bienestar estuvo al servicio de la economía capitalista y, como señalaron algunos teóricos, su finalidad era gestionar la plusvalía en beneficio del sector privado. ${ }^{155}$ Aunque, tal vez, lo más importante sea mencionar que el Estado del bienestar no fue capaz de salvar las contradicciones que le eran inherentes:

1) Por un lado apoyaba la mercantilización de las relaciones de producción para sostener al capital, y por otro, insistía en des-mercantilizar esas relaciones a través del gasto público, aunque tal situación no era totalmente veraz, porque el gasto social tenía por finalidad fundamental no garantizar y posibilitar los derechos sociales, sino conservar el sistema capitalista de producción.

2) La planificación económica que se impulsó en algún momento del desarrollo del Estado del bienestar fue continuamente debilitada por los propios inversionistas que se oponían a cualquier socialización de las relaciones de producción.

3) En síntesis, la incompatibilidad entre la construcción de un Estado de socialismo democrático al que aspiraban algunos socialdemócratas, y la permanencia de un Estado capitalista que gestionaba la plusvalía en beneficio de los inversionistas y del sistema capitalista en su conjunto. ${ }^{156}$

El nuevo pensamiento liberal y neoliberal que cuestiona el Estado del bienestar condena profundamente el concepto de justicia social y hasta el de igualdad de oportunidades en algunas de sus vertientes. La igualdad que

154 O’ Connor, James, La crisis fiscal del Estado, Barcelona, Península, 1981.

155 Galgano, Francesco, Las instituciones de la economía capitalista, Valencia, Fernando Torres, 1980, p. 6.

156 Offe, Claus, Contradicciones en el Estado del bienestar, op. cit., pp. 41-71. 
Este libro forma parte del acervo de la Biblioteca Jurídica Virtual del Instituto de Investigaciones Jurídicas de la UNAM

ellos aceptan es exclusivamente la igualdad formal ante la ley. ${ }^{157}$ La igualdad material para los nuevos liberales no es aceptable porque aducen que en la realidad no existe, en la facticidad social y económica, lo que se manifiesta es la desigualdad humana. Los sistemas jurídicos y económicos no deben ser forzados a obtener una igualdad social, porque que se contraría la naturaleza de las cosas. La realidad no puede ser modificada con artificios institucionales y debemos aceptar nuestra desigualdad innata.

Para autores como Hayek, los Estados del bienestar conducen al totalitarismo porque restringen la libertad humana y la del mercado. En este sentido, condenan la planificación económica, la socialización de las inversiones, la economía mixta y los principales instrumentos del Estado del bienestar. La intervención del Estado en la economía es anti productiva, no es eficaz ni eficiente. Las empresas privadas son muy superiores en organización y productividad a las empresas públicas que están lastradas por la ineficacia, ineficiencia, el burocratismo y sus altos costos de operación que llevan al despilfarro y al desperdicio de los recursos económicos. Pero más allá de las críticas económicas, y como señaló en su momento Ralph Dahrendorf, 158 lo medular del cuestionamiento neoliberal no es que el Estado del bienestar atente contra el libre mercado, sino que destruye la misma libertad de las personas.

Entre los teóricos neoliberales hay una crítica consistente y frontal al proteccionismo comercial interno. Dicen ellos que el proteccionismo, ante la ausencia de competencia internacional, estimula la conformación de empresas privadas y públicas deficientes. ${ }^{159}$ Los productos que elaboran esas empresas no son de calidad ni los precios son los que corresponderían a los bienes y servicios que se ofrecen. Los consumidores tienen que aceptar esos productos a sabiendas que están deficientemente manufacturados. Además de promoverse el contrabando para obtener mejores productos y servicios, en muchas ocasiones, esas empresas necesitan estar subsidiadas con recursos públicos para poder mantenerse en condiciones de salud económica, lo que agrava la situación de las finanzas públicas y constituye un peso adicional en el funcionamiento transparente y eficiente de las haciendas públicas.

Para los neoliberales, las propuestas para resolver las crisis económicas consisten en: fortalecer el mercado y la libre competencia; aceptar que el mercado puede y hasta debe funcionar con márgenes de desempleo; reducir la presión fiscal a las empresas; facilitar líneas de crédito de fondos públicos

157 Hayek, Friedrich A., The Road to Serfdom, Chicago, Chicago University, 1944.

158 Dahrendorf, Ralph, Oportunidades vitales, Madrid, Espasa Calpe, 1982.

159 Friedman, Milton, y Friedman, Rose, La tiranía del status quo, Barcelona, Ariel, 1984. 
Este libro forma parte del acervo de la Biblioteca Jurídica Virtual del Instituto de Investigaciones Jurídicas de la UNAM

en condiciones favorables - que el Estado subsidie y rescate a las empresas - ; fomentar actividades del capital en los mercados exteriores, y aplicar una política económica puramente monetarista, que en principio tiene que conducir a un aumento del ahorro que, conjugado con todos los elementos, recompondrá el nivel de inversión - lo que, como vimos con Keynes, no se produce mecánicamente- - Se busca que el Estado no se abstenga de la economía como sostenían la tesis de Adam Smith, de lo que se trata es de que intervenga en la economía, pero no para favorecer y proteger a los desvalidos, a los trabajadores o marginados de las sociedades, sino para fortalecer las finanzas y las capacidades de las empresas privadas. En pocas palabras, con el neoliberalismo los beneficios de las empresas se privatizan y las pérdidas se socializan a través del empleo de recursos públicos en el apuntalamiento o en el rescate de ellas.

En la visión económica neoliberal, el Estado está obligado a privatizar sectores económicos y empresas públicas, las que pasarán a manos de empresarios nacionales y extranjeros. El argumento para esas privatizaciones y liberalizaciones es que las empresas del Estado suelen actuar con prevalencia o monopólicamente; además de que funcionan con despilfarro y corrupción, y con ello, se rompen las condiciones de libre competencia y simetría que deben prevalecer en el mercado. Si el Estado quiere participar en el mercado debe, en todo caso, hacerlo en igualdad de condiciones con las empresas privadas - siempre admitiendo que esa no es función del Estado-. Igualmente, el espíritu emprendedor de los neoliberales los lleva a sostener que casi todo, bienes o recursos, incluyendo la naturaleza o la cultura, deben estar en el mercado y someterse a su racionalidad económica, pues una sociedad en la que todo tiene precio no es que sea inhumana o cruel, es sólo racional. Aquí es muy importante señalar, que en el mundo capitalista del nuevo liberalismo, sólo a los empresarios nacionales y extranjeros les corresponde decidir cuánto, cómo y dónde se invierte, pues si se cuestiona ese principio, como exigiría una política consecuente con el principio del pleno empleo, el capitalismo se transformaría en un sistema diferente.

Los puntos de vista económicos neoliberales también pueden verse desde otras perspectivas. Así, Ignacio Sotelo, considera que los capitalistas nunca estuvieron a favor del principio de pleno empleo keynesiano, porque ello fortalecía a los sindicatos y mermaba la capacidad de disciplinar y controlar la mano de obra ocupada. Con el pleno empleo se consigue una redistribución de la renta más equilibrada, la clase obrera impone salarios más altos y mejores condiciones de trabajo. En suma, un capitalismo de pleno empleo tiende a desarrollar instituciones sociales y políticas que reflejan el poder 
Este libro forma parte del acervo de la Biblioteca Jurídica Virtual del Instituto de Investigaciones Jurídicas de la UNAM

creciente de la clase trabajadora, lo que a la larga hubiese supuesto también una profunda transformación del sistema capitalista. Era obvio que los capitalistas no iban a permitir que ello ocurriera porque estaba en juego el control de las inversiones - cuánto, cómo y dónde se invierte- y con ello, su misma existencia como clase. Los inversionistas privados no toleraron el ensanchamiento del poder en la clase trabajadora. Se dejó crecer a los sindicatos y se aceptaron muchas de sus demandas, pero nunca para poner en riesgo al propio sistema capitalista. ${ }^{160}$

Sin embargo, desde nuestro punto de vista, lo que vino a alterar y poner en crisis el Estado del bienestar de manera claramente manifiesta es el fenómeno económico conocido como globalización. La internacionalización de la economía ha sido el factor decisivo para restaurar una forma de capitalismo mundial y remover al Estado del bienestar de su sitial. ¿Por qué? Porque la internacionalización de la economía obliga a desregular las actividades económicas, si el Estado nacional insiste en ellas, las trasnacionales deslocalizan las inversiones y buscan naciones desreguladas. Igual ocurre con los impuestos, con las prestaciones y derechos sociales a los trabajadores, con las regulaciones a favor del medio ambiente o con la salud. A nivel internacional, las instituciones jurídicas y políticas existentes no poseen los medios del viejo Estado-nación para, no digamos subordinar al capital internacional a los derechos humanos, sino, al menos, actuar como interlocutor del mismo. En los hechos, hemos regresado a un estado de naturaleza, en donde las reglas del funcionamiento del mercado las impone el más fuerte. Las instituciones económicas y financieras globales, como el Fondo Monetario Internacional o el Banco Mundial, se supeditan a las nuevas condiciones del mercado internacional, y sus agentes actúan como una burocracia al servicio de esos esquemas. Desde el punto de vista de las causas económicas de la crisis del Estado del bienestar podemos decir que éstas no sólo limitaron al Estado del bienestar sino al Estado-nación mismo.

La complicidad de las grandes empresas nacionales y trasnacionales con el Estado-nación pertenece al pasado, pues hoy las multinacionales actúan económicamente al margen de los Estados, sobre todo de los más débiles, y además, cuando quieren, les imponen las condiciones más onerosas. En estos años, la política social que corresponde al mundo globalizado es la privatización de los derechos humanos de carácter social, en donde el costo de esos derechos es soportado por los propios ciudadanos de las naciones o

160 Sotelo, Ignacio, El Estado social. Antecedentes, origen, desarrollo y declive, op. cit., pp. 275 y 276 . 
Este libro forma parte del acervo de la Biblioteca Jurídica Virtual del Instituto de Investigaciones Jurídicas de la UNAM

de los Estados, mientras que los grandes beneficios son para las empresas, principalmente las trasnacionales. Lo que tenemos ahora es una reducción en la garantía de los derechos sociales en todo el mundo y una ampliación exponencial de los beneficios de las empresas. Un mundo en el que ni los capitalistas del siglo XIX pensaron.

Otra herida en el Estado del bienestar fue el sistema político que construyeron los partidos y los gobiernos de los países industrializados. La democracia implantada fue superior a la del XIX porque se concedió el voto universal a mujeres y hombres, y en general, con la excepción de países, como Estados Unidos, la elección de las autoridades se realizaba a través del voto directo. Sin embargo, los sistemas políticos de los países industrializados, y formalmente democráticos, fueron demostrando durante la vigencia del Estado del bienestar su desconexión con las sociedades. El divorcio gobernante-gobernado fue palpable y al momento de la crisis del modelo del bienestar, sus instrumentos fueron impotentes para mantener las conquistas sociales obtenidas.

La democracia del Estado del bienestar fue, como señaló Schumpeter, ${ }^{161}$ un mero mecanismo para la selección de élites, o como dijo Popper, ${ }^{162}$ un procedimiento de destitución de gobernantes. La democracia en esta concepción formal y minimalista se concreta y concluye en lo electoral sin que importe mucho la calidad de las reglas e instituciones o el nivel de participación y deliberación de los asuntos públicos; se trata de una mistificación que paraliza el sentido de la democracia en el tiempo. ${ }^{163}$ La democracia pone fin a la historia si es sólo una cuestión de reglas y procedimientos para saber quién gobierna y cómo gobernará.

Las visiones minimalistas de la democracia centradas en lo electoral, además de incorrectas son falsas si tratamos de concebir a la democracia desde sus fines - garantizar la libertad, la igualdad y la justicia-. Los principios de elecciones libres, auténticas y periódicas, aunque se satisfagan no son suficientes ${ }^{164}$ porque la ciudadanía no tiene sólo una dimensión política, sino una social que mira o debe mirar por el bienestar de las personas y que procura reforzar la civilidad y potenciar las redes del beneficio social. No

161 Schumpeter, Joseph, Capitalism, Socialism and Democracy, Nueva York, Harper, 1962, pp. 219 y ss.

162 Popper, Karl, La sociedad abierta y sus enemigos, Barcelona, Paidós Ibérica, 2010.

163 De Vega, Pedro, "La democracia como proceso. (Algunas consideraciones desde el presente del republicanismo de Maquiavelo)", en Guerra, Alfonso, y Tezanos, José Félix (eds.), Alternativas para el siglo XXI. I Encuentro Salamanca, Madrid, Editorial Sistema, 2003, p. 465.

164 Bobbio, Norberto, Teoría general de la política, Madrid, Trotta, 2003, pp. 459 y 460. 
Este libro forma parte del acervo de la Biblioteca Jurídica Virtual del Instituto de Investigaciones Jurídicas de la UNAM

podemos ver a las personas como individuos aislados y atomizados, ${ }^{165}$ la ciudadanía tiene también una dimensión económica; es decir, los ciudadanos deben con sus conciudadanos decidir qué se produce, cómo y para qué - la democracia económica a la que nunca llegó el Estado del bienestar - Además, la democracia tiene que ver con los resultados de las decisiones colectivas, éstos deben beneficiar también a las mayorías de cada sociedad. ¿Qué sentido tiene que elija la mayoría si los resultados de las decisiones colectivas benefician sólo al 1\% de una minoría?

¿Puede decidir una élite nacional o transnacional sin escuchar a los sectores involucrados, sin dar la debida participación en las decisiones a los que sean ciudadanos más allá de los momentos electorales, sin la deliberación y transparencia necesaria? Nosotros consideramos que no todos los procedimientos importan o valen lo mismo, hay de procedimientos a procedimientos. Algunos son más abiertos, más transparentes o más deliberativos y participativos ${ }^{166}$ que otros. No es lo mismo, por ejemplo, contar con procedimientos que promuevan la oligarquización en los partidos, que otros que atiendan la democracia interna en ellos; o bien, que la democracia sea electoral, o que siéndolo, también promueva instrumentos participativos y deliberativos; no todos los modelos de división de poderes, en forma de gobierno o de estado federal, son iguales y dan lo mismo en términos del nivel y calidad de la democracia.

Lo anterior nos demuestra que la democracia no significa sólo la existencia de elecciones y partidos competitivos, seguramente por ahí se empieza; pero eso no basta para hablar de democracia y mucho menos de la democracia que exigía el Estado del bienestar. Las posiciones minimalistas de Schumpeter o de Popper, como lo ha demostrado Larry Diamond, ${ }^{167}$ conllevan a la falacia electoralista pues por no contar con elecciones se califica a un país de democrático. Por ello, es necesario ver cómo se garantizan las libertades y las modalidades de expresión de la sociedad civil; en otras palabras, los requerimientos institucionales de la democracia, como el Rule of Law, la división de poderes, la rendición de cuentas, y en general, advertir si las condiciones o elementos institucionales del ejercicio del poder forman parte integrante del concepto de democracia. Las reglas e instituciones electorales, por sí mismas, sin otros arreglos institucionales que promuevan

165 Cortina, Adela, "Claves para un desarrollo de la democracia", en Guerra, Alfonso, y Tezanos, José Félix (eds.), Alternativas para el siglo XXI. I Encuentro Salamanca, op. cit., p. 418.

166 Díaz, Elías, "La universalización de la democracia", en Guerra, Alfonso, y Tezanos, José Félix (eds.), Alternativas para el siglo XXI. I Encuentro Salamanca, op. cit., pp. 439-459.

167 Diamond, Larry, Developing, Democracy Toward Consolidation, Baltimore, The Johns Hopkins University Press, 1999. 
Este libro forma parte del acervo de la Biblioteca Jurídica Virtual del Instituto de Investigaciones Jurídicas de la UNAM

los derechos humanos, fundamentalmente los sociales, hacen imposible que hablemos de una democracia. ${ }^{168}$

Además, es empobrecedor para cualquier sociedad pensar en la democracia exclusivamente desde una perspectiva instrumental y formalista. ${ }^{169}$ La democracia es, sobre todo, un proceso en construcción permanente, en búsqueda de los principios y valores que la conforman: el principio de igualdad intrínseca de todos los miembros de la comunidad política y el principio de la autonomía personal. ${ }^{170} \mathrm{Y}$ ello entrañaba, para el Estado del bienestar, que los ciudadanos decidieran: qué se produce, cómo y para qué - la socialización de las inversiones que había pedido Keynes para el logro del pleno empleo- - La democracia del bienestar nunca realizó la democracia social ni la económica, y la política formal e instrumental, tuvo el demérito de alejar a los ciudadanos de las decisiones colectivas. Hubo propuestas para construir un socialismo democrático pero éstas no se materializaron. ${ }^{171} \mathrm{Al}$ ponerse en práctica los instrumentos de la democracia electoral para contener la crisis del Estado del bienestar, éstos fueron insuficientes para revertir el nuevo modelo de Estado neoliberal que se conformaba.

En el plano sociológico, las sociedades surgidas del Estado del bienestar no pasaron a la acción colectiva que permitiera consolidar el modelo. La democracia social, al igual que la democracia económica, no fue una realidad al interior de los Estados del bienestar. La propiedad, el contrato, las formas establecidas de desigualdad social, el matrimonio, la familia, etcétera, se expresaron como un ámbito diferenciado del sistema político. Eran instituciones que se aceptaban acríticamente por distintos sectores sociales - salvo algunas excepciones de lo que se llamó la contracultura, por ejemplo-, no se cuestionaban ampliamente y formaban parte de lo que los ciudadanos estimaban su vida personal o íntima, la que estaba separada de la esfera pública y que no era susceptible de deliberación y de movilización política. Las relaciones sociales no se democratizaron suficientemente durante la vigencia del Estado del bienestar. Éste no promovió sociedades más comunitarias, de respaldo y apoyo mutuo entre sus miembros, sino que

168 Przeworski, Adam, "Minimalist Conception of Democracy: a Defense”, en Shapiro, Ian, y Hacker-Cordón, Casiano, Democracy's Value, Cambridge, Cambridge University Press, 1999, pp. 23-55.

169 De Vega, Pedro, "La democracia como proceso. (Algunas consideraciones desde el presente del republicanismo de Maquiavelo)", op. cit., p. 462.

170 Cortina, Adela, "Claves para un desarrollo de la democracia”, op. cit., pp. 411 y 412.

171 Strachey, John, El capitalismo contemporáneo, México, Fondo de Cultura Económica, 1974; y Díaz, Elías, Legalidad-legitimidad en el socialismo democrático, Madrid, Civitas, 1978. 
Este libro forma parte del acervo de la Biblioteca Jurídica Virtual del Instituto de Investigaciones Jurídicas de la UNAM

ahondó el individualismo y el particularismo, bajo la fiebre de las sociedades del ocio, del consumo y del espectáculo. ${ }^{172}$

Claus Offe explica que las sociedades del Estado del bienestar no fueron plenamente autoconscientes por las siguientes razones:

1) Existieron siempre disparidades en las expectativas de vida de los asalariados y éstas tenían su origen en las características y fortalezas de cada uno de los sindicatos, en las diferencias de condiciones que había entre los diversos sectores industriales, y también en razones étnicas, de región, de género, etcétera. No existió, por tanto, la cohesión suficiente entre la clase obrera.

2) El logro del pleno empleo no pasó de ser un objetivo en muchas sociedades, hubo grupos sociales que se mantuvieron en el desempleo abierto o encubierto, lo que propició que fueran políticamente muy vulnerables, y culturalmente no brindaran la adhesión plena y consciente al sistema que se construía.

3) Las grandes alianzas pro Estado del bienestar sólo podían prosperar en los buenos tiempos de crecimiento económico y pleno empleo, y aún en esas circunstancias, los beneficios se revertían para la acción colectiva y el cambio social, porque las personas preferían el ocio y el consumo a la transformación socio-económica.

4) El apoyo político de los ciudadanos a las sociedades del Estado del bienestar fue siendo decreciente, porque éstos recibían algunos de sus beneficios pero advertían que éstos no eran auténticamente redistributivos de la riqueza, consideraban que eran paliativos para enfrentar la desigualdad.

5) Desgraciadamente prevalecieron las orientaciones anti-colectivistas y anti-Estado del bienestar en las sociedades. Éste no logró calar con profundidad en la cultura y en todas las representaciones de la hegemonía, para que los ciudadanos lo defendieran activamente en los momentos en que se debilitaba y se sustituía por otro. ${ }^{173}$

Cuando la globalización llegó, los cambios tecnológicos ocurrieron, se fracturó el socialismo real; se universalizó el ingreso de la mujer al mundo laboral, y las grandes migraciones de los países subdesarrollados a los desarrollados se manifestaron. Las sociedades del Estado del bienestar de los países industrializados quedaron pasmadas ante la importancia de todos esos cambios sociales, políticos y económicos, y no pudieron ni ellos ni sus

172 Luhmann, Niklas, Teoría política en el Estado de bienestar, Madrid, Alianza Editorial, 1981.

173 Offe, Claus, Contradicciones en el Estado del bienestar, Madrid, Alianza Editorial, 1990, pp. 202-205. 
Este libro forma parte del acervo de la Biblioteca Jurídica Virtual del Instituto de Investigaciones Jurídicas de la UNAM

clases gobernantes, dar respuesta adecuada a estas modificaciones. Tan sólo balbucieron el lenguaje y las conductas de odio hacia lo que era novedoso y diferente; pero carecieron de la capacidad para reconocer lo que implicaba el Estado del bienestar para sus vidas y para la organización social, y por qué era preciso defenderlo, perfeccionarlo o transformarlo para edificar nuevas formas organización política y social que maximizaran los derechos sociales y los principios democráticos.

Por eso ahora, los teóricos anti-neoliberales insisten en el concepto de hegemonía de inspiración gramsciana para defender y consolidar concepciones diversas de sociedad y Estado. Dice Boaventura de Sousa Santos, que necesitamos hegemonías alternativas a las que promueve el neoliberalismo porque la actual que se entiende como

...el conjunto de ideas sobre la sociedad e interpretaciones del mundo y de la vida que, por ser altamente compartidas, incluso por los grupos sociales perjudicados por ellas, permiten que las elites políticas, al apelar a tales ideas e interpretaciones, gobiernen más por consenso que por coerción, aun cuando van en contra de los intereses objetivos de grupos sociales mayoritarios... ${ }^{174}$

Lo que significa que la lucha social y política tiene que ver también con el enfrentamiento de las representaciones ideológicas y culturales que los grupos sociales tienen sobre su realidad.

Jurídicamente, y lo analizaremos en el epígrafe siguiente, el Estado del bienestar también fracasó porque la teoría y práctica jurídica que produjo no logró consolidarlo y/o perfeccionarlo. Los derechos económicos, sociales, culturales y ambientales, nunca lograron el grado de exigibilidad que tenían los derechos liberales y los principios democráticos, como lo hemos explicado antes, no pasaron de la materialización de una democracia electoral que divorciaba a los gobernantes de los gobernados. Las teorías jurídicas más radicales del Estado del bienestar, como las escuelas del uso alternativo del derecho, el constitucionalismo popular o los Critical Legal Studies, han sido movimientos jurídicos minoritarios despreciados por las clases jurídicas de los países industrializados. En general, las estructuras institucionales y jurídicas del Estado del bienestar no se democratizaron como correspondería a sus objetivos, porque ello implicaba poner en riesgo el poder de la élite política y económica que gobernaba y que representaba sustancialmente los intereses del gran capital.

174 Santos, Boaventura de Sousa, "La izquierda del futuro: una sociología de las emergencias", La fornada, México, 5 de enero de 2016, p. 14. 
Este libro forma parte del acervo de la Biblioteca Jurídica Virtual del Instituto de Investigaciones Jurídicas de la UNAM

\section{EL MODELO JURÍDICO DEL ESTADO DEL BIENESTAR}

La concepción jurídica del Estado del bienestar se apoya en algunas variables y categorías jurídicas precisas: 1) reconocimiento constitucional y legal de los derechos económicos, sociales y culturales, y posteriormente ambientales, así como de otras generaciones de derechos aunque con garantías institucionales deficientes; 2) crecimiento de la administración pública, de la burocracia y del gasto público del Estado para satisfacer los derechos reconocidos; 3) principio de legalidad matizado por disposiciones administrativas reglamentarias que reciben de la ley y a favor de la administración pública una delegación de competencias; 4) comienzo de entendimiento de la Constitución como normativa y no sólo nominal o semántica; 5) fortalecimiento del control de constitucionalidad y de los jueces constitucionales; 6) nuevas concepciones sobre la ciencia jurídica y la validez jurídica; 7) mayor peso de los tratados sobre derechos humanos en el derecho interno; 8) sistema democrático pluralista; 9) debate entre la capacidad de transformación o de pacificación de la Constitución sobre el sistema económico-social, y 10) el logro del Estado del bienestar a través de la legislación fiscal y presupuestal.

El reconocimiento constitucional y legal de los derechos económicos, sociales, culturales y ambientales, significó un avance civilizatorio muy importante, al menos por dos razones: 1) no podía generarse un orden social espontáneo, el mercado producía enormes desigualdades y el Estado debía intervenir para resolverlas o compensarlas, reconociendo los nuevos derechos, y 2) las perspectivas económicas, políticas y jurídicas sobre la existencia de una mano invisible, un equilibrio cibernético de fuerzas, un orden espontáneo convencional - sin derechos económicos y sociales - eran insostenibles para la noción de Estado del bienestar. ${ }^{175}$

De esta suerte, el Estado del bienestar debía potenciar los derechos de libertad como lo había hecho el viejo Estado liberal de derecho, pero también debía maximizar los de igualdad. La incorporación de los derechos de igualdad en las Constituciones producían ventajas sociales evidentes: armonizaban el tejido social, pacificaban a las sociedades, y en algunos casos, catalizaban los procesos de transformación social hacia la construcción de sociedades cada vez más justas y equilibradas. Las Constituciones del siglo XX se dieron a la tarea de reconocer los derechos económicos, sociales, culturales y ambientales; a elaborar la legislación secundaria que los posibi-

175 Zagrebelsky, Gustavo, El derecho dúctil. Ley, derechos, justicia, op. cit., p. 98. 
Este libro forma parte del acervo de la Biblioteca Jurídica Virtual del Instituto de Investigaciones Jurídicas de la UNAM

litara a establecer las competencias y responsabilidades de las autoridades para su satisfacción.

El problema es que los derechos de igualdad eran, aunque no en todos los casos, costosos, implicaban grandes erogaciones de la hacienda pública para satisfacerlos porque comportan obligaciones de dar y de hacer a cargo del Estado, y por eso, el tema de su eficacia resultaba tan importante. ${ }^{176}$ No siempre los fiscos de los Estados estaban dispuestos a destinar los recursos que satisficieran los derechos de igualdad porque se tenían otras prioridades, o si lo estaban, no contaban con la riqueza fiscal necesaria para garantizarlos. Además del problema de las garantías económicas, también había un problema con las garantías jurídicas - con las vías de exigibilidad y justiciabilidad de los derechos económicos, sociales, culturales y ambientales-. La estructura jurídica de los Estados aún respondía a las categorías y esquemas del Estado liberal de derecho, pero poco a poco, la administración pública de los Estados del bienestar estableció los programas sociales y las políticas públicas de carácter administrativo para satisfacerlos. Igualmente, los tribunales jurisprudencialmente fueron reconociendo y ampliando los derechos y perfeccionando sus garantías. Sin embargo, en muchos países, los instrumentos procesales de exigibilidad y justiciabilidad de derechos económicos, sociales, culturales y ambientales, no estuvieron nunca a la par a los que correspondían a los derechos de libertad. ${ }^{177}$ Existe y ha existido un tratamiento procesal de garantías diferenciado; en México, por ejemplo, no contamos con un amparo social que los tutele.

La evolución del Estado del bienestar demostró la dificultad para cumplir con las garantías económicas - la crisis fiscal del Estado y con ello la crisis del Estado del Bienestar - pero también con las garantías jurídicas. Hoy en día, se tiene claridad que la evolución del derecho internacional de los derechos humanos ha conducido a una comprensión unitaria del conjunto de los derechos humanos y al reconocimiento de su universalidad, indivisibilidad, interdependencia y progresividad, y que los Estados deben respetarlos, protegerlos, cumplirlos e informar sobre su satisfacción. ${ }^{178}$ No obstante, el Comité de Derechos Económicos, Sociales y Culturales de la Organización de Naciones Unidas (ONU) reconoce, en un lenguaje ambiguo, la imposibilidad de satisfacerlos, aunque pide a los Estados que adop-

176 Bobbio, Norberto, El tiempo de los derechos, Madrid, Sistema, 1991.

177 García Sayán, Diego, "Nueva senda para los derechos económicos, sociales, culturales y ambientales", Revista de la Comisión Internacional de furistas, núm. 55, 1995, número especial.

178 García Aniza, Fernanda, Los derechos económicos, sociales, culturales y ambientales (DESCA) como derechos exigibles en el nuevo constitucionalismo latinoamericano, México, Comisión Nacional de los Derechos Humanos, 2015, pp. 20 y 21. 
Este libro forma parte del acervo de la Biblioteca Jurídica Virtual del Instituto de Investigaciones Jurídicas de la UNAM

ten todas las medidas que sean necesarias para su realización para que éstas puedan ser justificadas en cada caso y evaluadas con posterioridad. ${ }^{179}$

Los organismos internacionales y nacionales de derechos humanos reaccionan así, y producen informes y recomendaciones sibilinas, porque son conscientes que la justiciabilidad, protección y eficacia de los derechos económicos, sociales, culturales y ambientales, precisan de algunas metas económicas básicas para su consecución, entre otras, las siguientes:

1) Incremento sustancial y autosustentable del producto nacional per cápita; 2) Distribución equitativa del ingreso nacional; 3) Sistemas impositivos adecuados y equitativos; 4) Modernización de la vida rural y reformas que conduzcan a regímenes equitativos y eficaces de tenencia de la tierra, mayor productividad agrícola, expansión del uso de la tierra, diversificación de la producción y mejores sistemas para la industrialización y comercialización de productos agrícolas; 5) Industrialización acelerada y diversificada, especialmente de bienes de capital intermedios; 6) Estabilidad del nivel de precios internos en armonía con el desarrollo; 7) Salarios justos, oportunidades de empleo y condiciones de trabajo aceptables para todos; 8) Erradicación rápida del analfabetismo y ampliación para todos de oportunidades en el campo de la educación; 9) Defensa del potencial humano mediante la extensión y aplicación de los modernos conocimientos de la ciencia médica; 10) Vivienda adecuada para todos los sectores de la población; 11) Condiciones urbanas que hagan posible una vivienda sana, productiva y digna; 12) Promoción de la iniciativa y la inversión privada en armonía con la acción del sector público, y 13) Expansión y diversificación de las exportaciones. ${ }^{180}$

Lo anterior pone de manifiesto que la eficacia de los derechos humanos de igualdad, depende de la existencia de una estructura económica básica como ha señalado el marxismo. La expuesta en el párrafo anterior, mutatis mutandis, corresponde con la estructura económica del Estado del bienestar, pero ésta ha sido olvidada a partir de que el Estado del bienestar entró en crisis en los años setenta del siglo XX. Hoy en día, la estructura económica del Estado neoliberal es otra -incompatible en gran parte con los tratados en materia de derechos económicos, sociales, culturales y ambientales-, no se pueden garantizar los derechos más preciados del Estado del bienestar: el derecho al trabajo, el derecho colectivo al pleno empleo, el derecho al salario remunerado, el derecho a una educación pública y de calidad,

179 E/C.12/2007/ 1, párrafo 4.

180 Hernández, Armando, Los derechos económicos, sociales, culturales y ambientales en el nuevo modelo constitucional de derechos humanos en México, México, Comisión Nacional de los Derechos Humanos, 2015, pp. 49 y 50. 
Este libro forma parte del acervo de la Biblioteca Jurídica Virtual del Instituto de Investigaciones Jurídicas de la UNAM

el derecho a la seguridad social, etcétera. Para satisfacer adecuadamente esos derechos tendríamos que generar condiciones económicas que la globalización neoliberal rechaza. En este sentido, podríamos decir que el Estado del bienestar fue valioso porque reconoció los derechos de igualdad; pero fracasó a la hora de satisfacerlos plenamente. El sistema capitalista que estaba detrás lo impidió y después apareció el de la globalización neoliberal que ha destruido las esperanzas que quedaban. ${ }^{181}$

Además, como lo ha explicado Gustavo Zagrebelsky, los derechos humanos alcanzan su significación a partir del cristal ideológico con el que se miran y se comprenden. ${ }^{182}$ Un mismo derecho humano, pongamos por ejemplo, el derecho al trabajo, es visto y entendido jurídicamente de manera diversa. Si lo apreciamos desde concepciones liberales clásicas, se entenderá como un contrato entre un patrón y un trabajador que libremente fijan las condiciones de trabajo; si lo analizamos desde posturas socialdemócratas, se asumirá no como un contrato, sino como un derecho humano vinculado a un salario justo, y si lo estudiamos desde el marxismo, se entenderá que las relaciones de trabajo no pueden ser justas porque el patrono se queda con la plusvalía que generó el trabajador. Cualquier derecho humano puede ser sometido a estas apreciaciones ideológicas o a otras, y siempre advertiremos que la manera teórica e ideológica de aproximarnos a los derechos humanos importa para su entendimiento, interpretación y alcances. Durante la existencia del Estado del bienestar, sobre todo en su fase de consolidación, se buscó apreciar los derechos económicos, sociales, culturales y ambientales desde perspectivas socialdemócratas, pero aún dentro de ellas, como lo hemos comentado a largo de estas páginas, existen y existieron aproximaciones diversas: algunas más a la izquierda y otras más moderadas, que desde luego impactaban en la consideración general de estos derechos por los operadores jurídicos nacionales e internacionales, y lo más trascendente, en su misma eficacia social y económica.

Igualmente, la teoría de los derechos humanos del Estado del bienestar no prohijó nuevos derechos humanos que pusieran en cuestión el modo de producción capitalista. ${ }^{183}$ Keynes señaló que la manera de lograr el pleno empleo, y con ello la realización del Estado del bienestar, implicaba la socialización de las inversiones. Los sindicatos, movimientos sociales y juristas del Estado del bienestar pudieron haber concebido un derecho humano con

181 Navarro, Vicenc, Bienestar insuficiente, democracia incompleta. Sobre lo que no se habla en nuestro pais, Barcelona, Anagrama, 2015.

182 Zagrebelsky, Gustavo, El derecho dúctil. Ley, derechos, justicia, op. cit., pp. 75-79.

183 Harvey, David, Espacios de esperanza, Madrid, Akal, 2012, pp. 281-288. 
Este libro forma parte del acervo de la Biblioteca Jurídica Virtual del Instituto de Investigaciones Jurídicas de la UNAM

sus correspondientes garantías, para que los trabajadores tuviesen participación directa en los procesos de producción económica - qué se produce, cuánto, dónde, cómo, etcétera-; sin embargo, ese nuevo derecho no fue recogido en los convenios y tratados internacionales. Los países que aceptaron ejercicios de cogestión fueron la excepción, y en algunos casos, los que la reconocieron inicialmente, después la abandonaron. La influencia del liberalismo en la traducción jurídica y significativa de los derechos económicos, sociales, culturales y ambientales tuvo un énfasis muy destacado, y los derechos a la igualdad reconocidos jurídicamente, no ampliaron de manera suficiente las fronteras para posibilitar la construcción de sociedades justas.

Durante el Estado del bienestar, el área de los poderes públicos que creció y se consolidó fue la administración pública. Si en el Estado liberal teóricamente el poder residió en el Parlamento, en el Estado del bienestar hubo un traslado de poder e influencia al Ejecutivo, específicamente a la administración pública. Ésta es y era, en primera instancia, la encargada de la gestión de los derechos económicos, sociales, culturales, y ambientales. De ese poder de la administración pública durante el Estado del bienestar podemos señalar algunas consecuencias para el Estado del bienestar que fueron evidentes:

1) La existencia de grandes aparatos burocráticos que se orientaban por su propia lógica no siempre coincidente con la lógica de los derechos humanos o con el principio de legalidad.

2) El incremento de la influencia jurídica de instrumentos normativos como el reglamento y normas administrativas generales, muchas veces en demérito de otras fuentes del derecho, principalmente de la ley.

3) Desequilibrios a favor del Ejecutivo entre los tres poderes clásicos.

4) Invasión y limitación de la autonomía de la voluntad de los ciudadanos por parte del reglamento y otras disposiciones administrativas de carácter general; ahora el ciudadano debía, además de no infringir la ley no transgredir el reglamento.

5) El poder, libertad y a veces arbitrariedad de la administración, para interpretar los alcances en el ejercicio de los presupuestos de los Estados.

6) Los enormes costos de la administración pública.

7) La irracionalidad en el gasto de la administración pública que desembocó en la crisis fiscal del Estado.

8) El incremento de actos de corrupción por el volumen y discrecionalidad en el manejo de los recursos administrados. 
Este libro forma parte del acervo de la Biblioteca Jurídica Virtual del Instituto de Investigaciones Jurídicas de la UNAM

9) En los países con menores niveles de desarrollo democrático, pero también en los más democráticos, el uso de los programas públicos gestionados por la administración, con fines clientelares y electorales.

10) La conformación de gobiernos de técnicos que se colocaban por encima de los otros poderes y del mismo ciudadano, el que quedaba excluido de la participación y de la crítica a la misma administración pública, propiciando una crisis de legitimidad democrática. ${ }^{184}$

El viejo principio de legalidad fue transformado, y con él, el principio de división de poderes. El legislador, por razones de la complejidad y del carácter técnico de las nuevas funciones del Estado, comenzó a delegar en distintos ámbitos sus competencias legislativas a la administración - la legislación delegada - La justificación de esa delegación se decía que era la ausencia de competencia técnica del Parlamento; así como el hecho de que la administración estaba más cerca de los problemas y los podía entender y regular mejor. No obstante, política y jurídicamente, la delegación muchas veces entrañaba que los principios y derechos del Estado del bienestar quedaban diluidos o deslustrados por consideraciones técnicas que debilitaban el contenido esencial de los derechos, y propiciaban una deriva autoritaria no compatible con la legitimidad democrática a la que se aspiraba. ${ }^{185}$ En estas condiciones, el Parlamento quedaba subordinado a la administración pública, que como tal, no tenía legitimidad democrática de origen y no siempre rendía cuentas con la profundidad necesaria al legislativo o a los ciudadanos.

Además, el principio de legalidad se afectó por otra circunstancia: la proliferación de leyes para regular muy diversas materias promovió leyes sectoriales, al grado que se contractualizaron sus contenidos. Las leyes del Estado del bienestar se negociaban entre grupos de interés diversos para atender aspectos parciales de la realidad, y cada negociación podía representar una vida efímera para los ordenamientos. No era ya importante mantener el carácter general y abstracto de la ley porque la ley se entendía como un instrumento político que permitía resolver coyunturas y no como un ordenamiento susceptible de aplicación para todos, sobre amplísimas materias, que estaba destinado a pervivir por largo tiempo para garantizar la certeza. En esta etapa del desarrollo del Estado del bienestar, contraria la lógica del viejo Estado liberal de derecho, encontramos clasificaciones di-

184 Kammler, Jörg, "El Estado social”, en Abendroth, Wolfgang, y Lenk, Kurt, Introducción a la ciencia política, Barcelona, Anagrama, 1971, pp. 91-124.

185 García Cotarelo, Ramón, Del Estado del bienestar al Estado del malestar, op. cit., pp. 164 y 165 . 
Este libro forma parte del acervo de la Biblioteca Jurídica Virtual del Instituto de Investigaciones Jurídicas de la UNAM

versas de las leyes: $a$ ) generales y abstractas; $b$ ) generales y concretas; $c$ ) particulares y abstractas, $\mathrm{y} d$ ) particulares y concretas. ${ }^{186}$

En síntesis, la ley ya no fue en el Estado del bienestar la expresión pacífica de la sociedad ni la manifestación de sociedades coherentes y unificadas. La naturaleza de la ley se desnudó y aparecieron en los ordenamientos y en conflicto, las fuerzas económicas, sociales y políticas que les habían dado origen. Las leyes del Estado del bienestar no sólo rompieron con el principio de certeza jurídica, sino con toda crudeza mostraron su carácter caótico y contradictorio. Lo anterior era consecuencia del fin de la uniformidad y de la homogeneidad de la sociedad burguesa que fundó el Estado liberal de derecho. En el Estado del bienestar, los conflictos de clase entre trabajadores y capitalistas se materializaron en las nuevas características de las leyes y en la pérdida relativa de relevancia del añoso principio de legalidad. La administración pública había impuesto su gran influencia y los Poderes Legislativos, pretendiendo atender los problemas económicos y sociales del Estado del bienestar, actuaban incoherentemente frente a ellos.

Un rasgo del Estado del bienestar que en nuestros días es aún más importante, tiene que ver con la conciencia de que la Constitución no sólo era un texto político y/o retórico, sino que es fundamentalmente un cuerpo normativo. ${ }^{187}$ La asunción de la Constitución normativa representa como ideología jurídica, un desarrollo civilizatorio significativo porque pretende que la realidad socio-económica coincida con las normas fundamentales y viceversa. No obstante, el reconocimiento de la Constitución normativa representó para el Estado del bienestar una decepción, en tanto que muchos de los derechos y principios de la Constitución; aunque así se pretendiera, no podían materializarse en la facticidad por las mismas condiciones de ambigüedad en las que se desenvolvió el Estado del bienestar. Como explicamos anteriormente, los derechos económicos, sociales, culturales y ambientales, no tuvieron plena y completa eficacia durante su vigencia, con lo que el carácter normativo de la Constitución, aunque se propalara, resultaba sólo un ejercicio discursivo, aunque como idea regulativa fuese totalmente apreciable y deseable.

A pesar de estas reflexiones, la noción de Constitución normativa con posterioridad a 1945, ha sido teórica y doctrinalmente muy importante para la construcción jurídica dominante de nuestro tiempo y que denominamos Estado constitucional y democrático de derecho. Ha permitido la

186 Bobbio, Norberto, Teoría general del derecho, Madrid, Debate, 1992, pp. 141-150.

187 Guastini, Riccardo, Estudios de teoría constitucional, México, Fontamara-UNAM, Instituto de Investigaciones Jurídicas, 2007, p. 153. 
Este libro forma parte del acervo de la Biblioteca Jurídica Virtual del Instituto de Investigaciones Jurídicas de la UNAM

consolidación de los tribunales constitucionales, y en paralelo a la evolución jurídica en torno a los derechos humanos, ha servido para ir construyendo una ciencia jurídica fundada en categorías jurídicas que durante el Estado liberal de derecho y en los inicios del Estado social carecieron de trascendencia. Nos referimos al control de constitucionalidad y convencionalidad; a la interpretación conforme y pro homine; a la diferenciación entre valores, principios y reglas; al garantismo; a los principios de interpretación de los derechos humanos, y a las doctrinas jurídicas en torno a esas realidades como el neoconstitucionalismo, que han superado el positivismo tradicional.

El Estado del bienestar, sobre todo después de 1945, fortaleció el papel de los Tribunales Constitucionales y de los jueces constitucionales en los sistemas jurídicos europeos; en Estados Unidos, su Corte Suprema, desde la decisión de 1803 en el caso Marbury vs. Madison, siempre tuvo el papel de árbitro y de último intérprete de la Constitución, y los jueces federales de ese país, a través del sistema Judicial Review tenían competencias de interpretación constitucional que les facultaban para desaplicar normas contrarias a la Constitución. En Europa, gracias primero a los impulsos de Kelsen y después a la doctrina jurídica alemana e italiana, y luego de los fallos de sus propios Tribunales Constitucionales, se comenzó a dar un cambio jurídico importante que le otorgaba a esos tribunales el poder de determinar el significado y alcance último de los principios y de los derechos humanos, y promovía una forma nueva de entender la interpretación y la argumentación: las leyes secundarias, como se dice ahora, tenían que interpretarse desde la Constitución - conforme a ella - y todo el ordenamiento jurídico requería estar irradiado por las normas de la Constitución a fin de ampliar o maximizar los derechos fundamentales y los principios democráticos - principio pro homine-. La transformación no fue sencilla y siempre existió tensión en los tribunales constitucionales, en parte, debido a la composición de sus integrantes porque algunos de los jueces constitucionales pensaban más la Constitución en términos de Estado liberal o Estado social - llegaban hasta la igualdad de oportunidades-, y otros querían y pretendían la consolidación de un auténtico Estado del bienestar, que impulsara a través de las decisiones jurisdiccionales de carácter constitucional los derechos humanos y los principios vinculados con la igualdad material o sustancial para ir más allá de la igualdad de oportunidades. ${ }^{188}$

Como hemos explicado, estos vaivenes fueron frecuentes, y los derechos sociales, económicos, culturales y posteriormente ambientales, nunca llega-

188 Doehring, Karl, "Estado social, Estado de derecho y orden democrático", en Abendroth, Wolfgang et al., El Estado social, op. cit., pp. 107-208. 
Este libro forma parte del acervo de la Biblioteca Jurídica Virtual del Instituto de Investigaciones Jurídicas de la UNAM

ron a estar al mismo nivel en cuanto a protección y garantía que los derechos de libertad. La razón de ello era obvia, no se trataba sólo de la voluntad de los jueces y magistrados de los tribunales constitucionales; la cuestión residía fundamental y destacadamente, en el modelo económico y los modos y relaciones de producción del Estado del bienestar. ¿Hasta dónde se podía llegar con el Estado del bienestar en el tema de la garantía efectiva de la igualdad social y material, lo permitía el sistema económico social de ese Estado? La respuesta, desde luego, está sujeta a gradaciones y matices, pero podemos decir que las decisiones jurisdiccionales de carácter constitucional en pos de la igualdad material llegan hasta el punto en donde se podía poner en riesgo el funcionamiento de la economía de mercado capitalista. Es decir, los jueces constitucionales — otra es la discusión sobre su legitimidad democrática - podían ampliar las fronteras de los derechos humanos vinculados a la igualdad material, siempre y cuando, no afectaran su base de sustentación. ${ }^{189}$

En la parte final y de transición del Estado del bienestar al Estado neoliberal es en donde los tratados sobre derechos humanos relacionados con la igualdad material tienen una enorme importancia. Las decisiones de los tribunales internos y supranacionales muestran los conflictos en torno a las fronteras de la igualdad material. Los controles de constitucionalidad, y ahora de convencionalidad, no llegan a garantizar plenamente - al menos no en el nivel que si lo hacen respecto a los derechos de libertad - los derechos económicos, sociales, culturales y ambientales, ni tampoco asomarse al cumplimiento de los objetivos de la igualdad sustancial.

El clima y las expectativas que producía el Estado del bienestar fueron muy importantes para modificar las categorías y concepciones clásicas del derecho del siglo XIX y de la primera mitad del siglo XX. Me voy a referir solamente a tres de ellas: la materia de estudio de la ciencia jurídica; el significado de la validez jurídica, y el papel de la interpretación y argumentación jurídicas. Las elijo porque muestran con cierta claridad la reelaboración jurídica que aconteció.

La primera está relacionada con el quehacer de la ciencia jurídica. Para Kelsen y antes de él, la función de la ciencia jurídica era describir su objeto que estaba constituido por el ordenamiento jurídico. Así, la ciencia jurídica era una ciencia neutral, descriptiva y poco crítica con el ordenamiento; lo recibía como algo dado y no lo ponía en cuestión. Con el desarrollo del Estado del bienestar aparecieron concepciones teóricas que pusieron en duda

189 García Pelayo, Manuel, Las transformaciones del Estado contemporáneo, Madrid, Alianza Editorial, 1987, p. 71. 
Este libro forma parte del acervo de la Biblioteca Jurídica Virtual del Instituto de Investigaciones Jurídicas de la UNAM

las bases epistemológicas y metodológicas de la ciencia del derecho; se empezó a entender que la ciencia del derecho no era para asumir el ordenamiento dado, pues la ciencia jurídica tenía una función fundamental en la transformación de los sistemas jurídicos y en la realidad social y económica. Las teorías del uso alternativo del derecho, los Critical Legal Studies o las teorías críticas, aunque no dominaron la escena jurídica, propusieron maneras distintas de concebir a la ciencia jurídica. Estas teorías estaban orientadas a la transformación del status quo. Aún la famosa teoría analítica de Hart, insistió en el fundamento sociológico de la regla de reconocimiento - de la validez jurídica - y con ella del derecho. ${ }^{190}$

Otra categoría fundamental que recibió una reelaboración teórica fue el concepto de validez jurídica. Para la teoría tradicional, al menos en el mundo continental europeo, las normas jurídicas se entendían como válidas si eran creadas por autoridad competente y mediante el procedimiento previamente establecido en las normas superiores. En algunos casos, también se exigía para la validez jurídica, que hubiese ciertos niveles de eficacia o de cumplimiento de las normas por parte de las autoridades y ciudadanos. Durante los años posteriores a 1945, después de los horrores de la Segunda Guerra Mundial, autores como Radbruch, señalaron que las normas eran inválidas si eran injustas, lo que implicaba un cambio en la manera de apreciar esta categoría jurídica. Sin embargo, los que más peso tuvieron en el cambio de la concepción de la validez jurídica fueron los tribunales constitucionales, ya que abrieron paso a la noción de que las normas jurídicas secundarias para ser válidas - tratado, ley o reglamento - requerían, además de los requisitos formales que indicaba la ciencia jurídica previa, desprenderse y derivarse materialmente - no sólo formalmente - de la Constitución misma. En otras palabras, si una norma secundaria se oponía a los derechos humanos reconocidos en la Constitución o a sus principios era inválida. Esta idea significaba, dado el carácter indeterminado de las normas constitucionales, que la validez estaba sujeta a la interpretación y argumentación de los jueces constitucionales, tal como en el sistema jurídico anglosajón, lo que suponía un desplazamiento de poder del Legislativo y del Ejecutivo al Tribunal Constitucional, aunque éste carecía de legitimidad democrática de origen.

La tercera de las categorías jurídicas que se modifica profundamente después de 1945, es la de interpretación y argumentación del derecho. El derecho ya no estaba constituido principalmente por las normas legisladas, el derecho era también interpretación y argumentación sobre esas normas

${ }^{190}$ Hart, Herbert L. A., El concepto de derecho, México, Editora Nacional, 1980. 
Este libro forma parte del acervo de la Biblioteca Jurídica Virtual del Instituto de Investigaciones Jurídicas de la UNAM

legisladas y sobre otras normas que no necesariamente provenían de los órganos del Estado - el pluralismo jurídico-. La interpretación y la argumentación no eran ya consecuencia de las operaciones mecánicas y silogísticas de jueces y tribunales, eran ejercicios de racionalidad y de razonabilidad jurídica, en donde la retórica, la lógica pragmática y el contexto socio económico, juegan un papel trascendente. ${ }^{191}$ No obstante, el nuevo arsenal interpretativo y argumentativo que propiciaron las teorías de la argumentación jurídica posteriores a 1945, ha resultado insuficiente para lograr la igualdad material, aunque en algunos Estados del bienestar y contemporáneos si ha permitido ciertos avances en su realización, sin que obviamente se ponga en crisis al sistema capitalista.

Una variable más del modelo jurídico del Estado del bienestar tiene que ver con la trascendencia de los tratados. Después de la constitución de la ONU y de la Declaración Universal de los Derechos Humanos de 1948, los convenios internacionales en la materia comenzaron a tener influencia en los sistemas jurídicos internos. En las fases finales del Estado del bienestar, sobre todo a partir del Pacto Internacional de Derechos Civiles y Políticos y del Pacto Internacional de Derechos Económicos, Sociales y Culturales de 1966 y de sus respectivos protocolos facultativos, los países industrializados ajustaron en diversa proporción su legislación interna y los criterios de sus tribunales a esas disposiciones. Esas circunstancias hacían ver que la garantía de los derechos económicos y sociales no era una cuestión sólo de políticas sociales asistenciales y opcionales, sino que se trataba de obligaciones a cargo de los Estados que comportaban responsabilidades internacionales en el supuesto de su no satisfacción. A pesar de ello, y como lo hemos venido sosteniendo, en las etapas terminales del Estado del bienestar, distintos gobiernos restringieron la materialización de los derechos económicos, sociales y culturales. Las administraciones conservadoras y socialdemócratas que dirigían a los países desarrollados elaboraron críticas, y posteriormente, políticas públicas en contra del avance de estos derechos al introducir planteamientos neoliberales en sus economías. Podemos decir que los Estados del bienestar, pese a reconocer la naturaleza de los derechos económicos y sociales como derechos humanos, tuvieron en los hechos, actitudes ambivalentes y de limitado compromiso hacia ellos, pues la visión económica neoliberal que iba consolidándose conspiraba en su contra.

Un factor a tomar en cuenta en este análisis es el sistema democrático pluralista, ${ }^{192}$ en tanto que, desde nuestro punto de vista, es una causa impor-

191 Cárdenas Gracia, Jaime, Manual de argumentación jurídica, México, Porrúa, 2014.

192 Dahl, Robert, La poliarquía, participación y oposición, Madrid, Tecnos, 2009. 
Este libro forma parte del acervo de la Biblioteca Jurídica Virtual del Instituto de Investigaciones Jurídicas de la UNAM

tante de la problemática implantación del Estado del Bienestar. Durante la vigencia de esta forma de Estado se apostó por la democracia electoral y de partidos, y no se quiso construir una democracia participativa y deliberativa, que hubiera permitido tener el esquema institucional para hacer progresar los fines del beneficio colectivo. La democracia pluralista promueve sistemas políticos democráticos de baja intensidad, en donde lo más importante es la competencia electoral entre las elites y oligarquías; pero también, el acuerdo y negociación entre ellas, es decir, el mantenimiento del status quo.

De esta suerte, las sociedades del Estado del bienestar podían elegir a los gobernantes en los momentos electorales; pero una vez que los representantes eran electos, los ciudadanos abandonaban la esfera pública y conferían a éstos la toma de todas las decisiones, sin conservar los instrumentos adecuados para su control social, político y jurídico. Si las sociedades del Estado del bienestar hubiesen tenido mayor incidencia en las decisiones y en los mecanismos de fiscalización del aparato gubernamental, otra suerte hubieren corrido. La vida política del Estado del bienestar descansó en sistemas electorales de reducido alcance democratizador y, en el Estado de partidos, ${ }^{193}$ oligarquizaba el poder en provecho de las políticas favorables al mantenimiento de las relaciones y modos de producción capitalista y en demérito del alcance protector y garantista de los derechos económicos y sociales.

El modelo jurídico del Estado del bienestar tuvo como tema de debate político y jurídico el ligado a la capacidad transformadora de las Constituciones. A éstas se podía, en el marco de lo social, dárseles un sentido progresivo pero también regresivo. Las Cartas fundamentales contienen derechos contrapuestos. En ellas existen principios que promueven lo individual, pero también lo colectivo; la libertad, pero también la igualdad, y la economía de mercado, pero igualmente la intervención del Estado en el ámbito de lo económico. ¿Qué principios deben ser atendidos y cuáles excluidos? En el plano abstracto es difícil contestar. Políticamente, la definición de cuáles son los principios a escoger deriva de quién es el que gobierna, aunque por la estructura de la democracia pluralista, la respuesta no es definitiva, porque en esta forma de democracia no sólo elegimos a uno de los que compite, sino que el modelo democrático está orientado al consenso y al compromiso entre quiénes lo hacen. Jurídicamente, la respuesta más plausible se ha decantado por un método o regla de solución de las colisiones entre principios jurídicos constitucionales que denominamos proporcionalidad o

193 García Pelayo, Manuel, El Estado de partidos, Madrid, Alianza Editorial, 1996. 
Este libro forma parte del acervo de la Biblioteca Jurídica Virtual del Instituto de Investigaciones Jurídicas de la UNAM

ponderación; ${ }^{194}$ sin embargo, el método conlleva siempre a la relativización de los principios y derechos, como lo ha explicado críticamente Habermas. ${ }^{195}$ Por tanto, durante el Estado del bienestar, el dilema discursivo sobre las capacidades transformadoras de las constituciones se mantuvo, y en la facticidad, se llegaba hasta donde se podía; esto es, hasta donde permitían las condiciones del sistema capitalista. Los políticos y los juristas del Estado del bienestar fueron conscientes de esta contradicción, que parece es insalvable: la Constitución puede permitir el cambio pero también ralentizarlo.

Finalmente, para el Estado del bienestar fue de gran trascendencia su marco fiscal y presupuestal. Se puede establecer que los teóricos del Estado del bienestar idearon una fiscalidad y una política de gasto público con el propósito de lograr la redistribución de la riqueza. ${ }^{196}$ Esta variable, como las anteriores que hemos comentado, presenta claroscuros. El sistema impositivo pretendía fortalecer el carácter progresivo de las contribuciones, y en materia de gasto público, la finalidad era incrementarlo para satisfacer de manera más amplia y exhaustiva los derechos sociales. Ambos objetivos presentaron problemas: la progresividad de los impuestos sobre los ingresos retraía las inversiones, y con ello, el crecimiento económico, pero éste era necesario, no sólo para maximizar los beneficios de los empresarios, sino para fortalecer la capacidad de la hacienda pública y distribuir mejor la riqueza, y en cuanto al incremento del gasto público, éste indubitablemente era finito, no se podía aumentar constantemente porque tendía al agotamiento de las finanzas públicas y a la llamada crisis fiscal del Estado. De esta manera, el Estado del bienestar contó, parcialmente, con los instrumentos fiscales y presupuestales que diseñó; pero nunca pudo considerarlos como absolutos y plenos; había límites en su materialización pues se llegaban a conseguir algunas metas de satisfacción de los derechos sociales, no al grado de estimar a la política fiscal como la vía hacia la igualdad sustancial. El Estado del bienestar jamás logró alcanzarla, aunque debe reconocerse que en algunos momentos lo intentó.

194 Alexy, Robert, "Epílogo a la teoría de los derechos fundamentales", Revista Española de Derecho Constitucional, Madrid, núm. 66, septiembre de 2002.

195 Habermas, Jürgen, Facticidad y validez, Madrid, Trotta, 1998, pp. 327 y ss.

196 Neumark, Fritz, Principios de la imposición, Madrid, Instituto de Estudios Fiscales, 1994, y Musgrave, Richard A., El futuro de la política fiscal, Madrid, Instituto de Estudios Económicos, 1980 . 
Este libro forma parte del acervo de la Biblioteca Jurídica Virtual del Instituto de Investigaciones Jurídicas de la UNAM

\section{CAPÍtulo CUARTO}

\section{EL ESTADO CONSTITUGIONAL}

\section{I. ¿QUÉ ES EL ESTADO GONSTITUGIONAL?}

Lo que denominamos Estado constitucional es una construcción de los juristas que comenzó a elaborarse en los años setenta del siglo pasado, y que hoy en día, en el discurso jurídico se mantiene como elaboración teórica dominante. Se trata del análisis y propuestas diversas que se han sucedido tanto en el mundo jurídico anglosajón, como en el continental europeo y latinoamericano. ${ }^{197}$ Los enfoques y preocupaciones de los autores dependen del contexto de su cultura jurídica y de los énfasis, mayores o menores, a alguno de los elementos o variables de Estado constitucional. Entre ellos podemos mencionar a Ronald Dworkin, Peter Häberle, Ernst Wolfgang Böckenförde, Robert Alexy, Gustavo Zagrebelsky, Luigi Ferrajoli, Luis Prieto Sanchís, Manuel Atienza, Carlos Santiago Nino y Miguel Carbonell, entre otros. ${ }^{198}$

Este tipo de Estado de nuestros días expresa, a diferencia de otras maneras de concebir al Estado, una concepción muy fuerte de los derechos humanos como fundamento y fin del Estado y del orden jurídico; un reforzamiento de la noción de Constitución normativa porque la Constitución, no sólo debe reconocer los derechos, sino garantizarlos plenamente - unir deber ser con el ser - ; una propuesta de democracia constitucional que no está basada en la regla de las mayorías ni en las unanimidades, sino en el respeto pleno de los derechos humanos - es una formulación a la vez pro-

197 En México, además de la teoría jurídica elaborada en los últimos años en el ámbito constitucional, podemos decir que la reforma constitucional en materia de derechos humanos, publicada el 10 de junio de 2011 en el Diario Oficial de la Federación, y algunas resoluciones de la Suprema Corte de Justicia de la Nación, como la dictada en el expediente varios 912/2010 (caso Rosendo Radilla), y la que atendió la contradicción de tesis 293/2011, que distinguió entre bloque y parámetro constitucional, son parte del proceso iniciado pero no consolidado ni mucho menos acabado, de constitucionalización del ordenamiento enmarcado en la lógica del Estado constitucional.

198 Carbonell, Miguel (coord.), Neoconstitucionalismo(s), Madrid, Trotta, 2003; mismo autor y García Jaramillo, Leonardo (coords.) El canon neoconstitucional, Madrid, Trotta, 2010. 
Este libro forma parte del acervo de la Biblioteca Jurídica Virtual del Instituto de Investigaciones Jurídicas de la UNAM

cedimental y sustantiva - ; en algunos autores es una insistencia de lograr a través del Estado constitucional la inclusión, el igualitarismo y la justicia, es decir, un Estado justo; una creciente aceptación de los tratados sobre derechos humanos y de las resoluciones de los organismos supranacionales que los tutelan; una importancia destacada al razonamiento judicial y a la argumentación jurídica, al grado de que se considere el derecho como práctica interpretativa, y el entendimiento que el Estado constitucional representa un orden jurídico sin soberano y que su papel es expresar la pluralidad jurídica de todos los proyectos jurídicos, políticos y sociales existentes. ${ }^{199}$

El Estado constitucional asume la ductilidad constitucional; es decir, la Constitución no puede representar a ningún proyecto particular, tanto jurídico como político, pues la Constitución es un marco que contiene todos los proyectos y principios de una sociedad pluralista. La norma fundamental acepta principios liberales y sociales, individualistas y comunitarios, a la libertad pero también la igualdad, a los derechos individuales y a los derechos colectivos, etcétera, por lo que ninguno de esos principios, valores y derechos prevalece a priori sobre los demás. En caso de conflicto entre ellos, se acude a métodos de solución jurídica que se aplican caso por caso y para esa situación específica. El principio de proporcionalidad o de ponderación, que es el método de resolución de colisiones, nunca implica que el principio perdidoso en el caso concreto pierda relevancia definitiva, en tanto que se tratará de protegerlo en la mayor medida posible, aunque otro sea el principio ganador. De esta suerte, los principios constitucionales están obligados a convivir y a enfrentarse pacífica e institucionalmente entre ellos, tanto en la arena política como en la jurídica, y dependerá de cada elección democrática o de la solución de algún caso que se ventile ante los tribunales, que algunos tengan una significación mayor, pero sólo transitoriamente. ${ }^{200}$

También el Estado constitucional entiende que, en las sociedades contemporáneas, el ordenamiento jurídico no es uniforme, sino contradictorio con múltiples lagunas y ambigüedades. Los ordenamientos se expresan como consecuencia de la pluralidad y heterogeneidad de nuestras sociedades. El papel de la Constitución es importante porque resuelve las incoherencias y dificultades que plantea el ordenamiento secundario a través de los principios y los valores que reconoce. Éstos representan una vía de unión social y jurídica entre los diferentes grupos de la comunidad, que aunque

199 Carbonell, Miguel y García Jaramillo, Leonardo, "Desafíos y retos del canon neoconstitucional", en Carbonell, Miguel y García Jaramillo, Leonardo (coords.), El canon neoconstitucional, Madrid, Trotta, 2010, pp. 11-27.

200 Zagrebelsky, Gustavo, El derecho dúctil. Ley, derechos, justicia, op. cit., pp. 9-20. 
Este libro forma parte del acervo de la Biblioteca Jurídica Virtual del Instituto de Investigaciones Jurídicas de la UNAM

opuestos entre ellos, han dado un respaldo a elementos destacados del sistema jurídico, tales como la libertad, la vida, la igualdad, la seguridad o la propiedad, sobre los que al menos en principio, debido a la indeterminación semántica de los principios y valores, existe convergencia y consenso. Sin embargo, la unidad que plantea el Estado constitucional es pluralista porque no se adscribe a la defensa o promoción de un principio o segmento de principios sobre los demás. Es una unidad en tensión entre los principios y los valores que contiene; no se trata de una unidad mecánica y absoluta, sino fluida y siempre relativa. ${ }^{201}$

El Estado constitucional reelabora el sistema de las fuentes jurídicas. Las Constituciones y los tratados sobre derechos humanos, tanto de libertad como de igualdad, ocupan un lugar de preponderancia respecto al resto del ordenamiento jurídico para determinar la validez jurídica. Lo que hacen la Constitución y los tratados es reconocer a los derechos humanos y expresarlos normativamente a través de principios y valores. A diferencia del viejo positivismo, las Constituciones no otorgan o dan derechos humanos a las personas, sino que positivan unos derechos humanos que son inherentes a cada ser humano y son preexistentes al Estado y a la Constitución. El ordenamiento jurídico, en su producción, aplicación, interpretación y argumentación, debe ajustarse a las normas superiores del sistema; concebirse conforme al texto constitucional y al de los tratados, y orientarse a la protección más amplia de las personas bajo los criterios de universalidad, interdependencia, indivisibilidad y progresividad de los derechos humanos. Además, en el Estado constitucional, todas las autoridades del Estado deben promover en sus actuaciones, garantizar, proteger, y en su caso, reparar las violaciones a los derechos humanos; así como entender que los fundamentos del edificio jurídico son, entre otros, la dignidad humana y la prohibición, por variables injustificadas, de la discriminación entre ellas.

En el Estado constitucional, sus guardianes últimos son los tribunales constitucionales. Ellos tienen la obligación de preservar y ampliar los derechos humanos mediante la interpretación y argumentación constitucional y convencional. Cada Estado es el encargado de ampliar o reducir las competencias de los tribunales constitucionales, pero no puede obviarse, que si el marco de competencias es mayor, su compromiso con los derechos humanos también deberá serlo. Por eso, debe buscarse que los tribunales constitucionales tengan una gran independencia y suficientes atribuciones para garantizar y maximizar a la totalidad de los derechos humanos. ${ }^{202}$ Los

201 Ibidem, pp. 39 y 40.

202 Häberle, Peter, El Estado constitucional, México, UNAM, 2001, pp. 159-161. 
Este libro forma parte del acervo de la Biblioteca Jurídica Virtual del Instituto de Investigaciones Jurídicas de la UNAM

tribunales constitucionales suelen plantear el problema de su legitimidad democrática. La tendencia general en la teoría y en la práctica, es la de valorar su legitimidad por su ejercicio, pero no por el origen de sus titulares; es decir, se señala que su justificación democrática se determina por la calidad y contenido de sus sentencias y no por los mecanismos de nombramiento o designación de sus jueces y magistrados.

El Estado constitucional igualmente implica una manera nueva de entender el ordenamiento jurídico. En éste existen distintos tipos de normas, entre otras, las reglas, los principios y los valores. ${ }^{203}$ Cada tipo distinto de normas tienen un significado para su debido tratamiento jurídico, pues no es lo mismo interpretar o argumentar una regla que un principio o un valor. No es casual que en el Estado constitucional, la interpretación y argumentación del derecho tengan la importancia que ahora tienen, y se considere totalmente superada la vieja equiparación entre interpretación y aplicación, y además, se estime que la interpretación mecánica y silogística, aún presente en los casos fáciles, no sea ya relevante para la solución de los casos difíciles.

En el Estado constitucional se reelaboran conceptualmente muchas de las categorías jurídicas tradicionales: la ciencia jurídica; la validez jurídica; la relación entre norma y caso; el papel de los operadores jurídicos; la nueva concepción de la interpretación y la argumentación, y sobre todo, el carácter cúspide que tienen ahora, en el sistema jurídico, los derechos humanos, sus garantías y los fines y valores superiores del ordenamiento, que irradian y conforman a todas las instituciones y normas jurídicas. ${ }^{204}$

Para el Estado constitucional, asemejándose a la tradición anglosajona, son muy importantes los contextos de los casos. Existe una fuerte impronta contextual y hermenéutica en la comprensión del derecho. Ni la norma jurídica ni el ordenamiento son ya los elementos nodales del derecho. Lo es la argumentación jurídica y los procedimientos deliberativos y pragmáticos que se desarrollan en torno de ella. El derecho es una práctica interpretativa más que un conjunto de normas y de instituciones jurídicas. ${ }^{205}$

La construcción del Estado constitucional recurre a los ordenamientos e instancias supranacionales de derechos humanos para resolver los conflictos del Estado nación, y por eso, acepta la crisis de la soberanía del Estado nación, no para indicar la muerte del Estado sino para promover que los derechos humanos deben globalizarse en todas las instancias mundiales; así

203 Dworkin, Ronald, Los derechos en serio, Barcelona, Ariel, 1984.

204 Prieto Sanchís, Luis, El constitucionalismo de los derechos, Madrid, Trotta, 2013.

205 Dworkin, Ronald, El imperio de la justicia, Barcelona, Gedisa, 1988. 
Este libro forma parte del acervo de la Biblioteca Jurídica Virtual del Instituto de Investigaciones Jurídicas de la UNAM

como en el derecho interno de los países desarrollados existe un cierto nivel de Estado constitucional, el mismo debe tener vigencia en el orden internacional: el Estado constitucional debe ser mundializado, ${ }^{206}$ además de constituirse en realidad en los Estados-nación donde aún no existe.

Podemos decir que el Estado constitucional es una cultura jurídica nueva, un paradigma teórico e ideológico que postula un Estado nación surgido de y para los derechos humanos y el desarrollo de los principios democráticos. En él, las instituciones y las leyes, así como el actuar de las autoridades y de los ciudadanos, se orientan a esos fines. En el Estado constitucional, las consideraciones sobre el poder, la población, el territorio, el gobierno, y el orden jurídico, no tienen relevancia jurídica si no son vistas con el prisma de los derechos humanos y de los fines del Estado Constitucional.

\section{LOS FUNDAMENTOS FILOSÓFICOS DEL ESTADO GONSTITUCIONAL}

Las bases filosóficas del Estado constitucional son siempre debatidas y sobre ellas existen matices diversos, pero podemos destacar cinco, que considero muy importantes para el desarrollo jurídico de esta forma de Estado. Éstas son:

1) Las relaciones entre moral y derecho, en donde la moral, suele tener una trascendencia que en el positivismo jurídico tradicional no tenía.

2) La consideración de la democracia constitucional que se aparta de las concepciones pluralistas de la regla de la mayoría, en tanto que la democracia tiene que ver con el respeto irrestricto a los derechos humanos y ni decisiones de mayoría o unánimes pueden ir en contra de ellos.

3) El poder de los jueces constitucionales que tienen las facultades para establecer los alcances y límites de los derechos humanos, además de resolver caso por caso - aunque a veces de manera general- las colisiones entre los principios constitucionales y convencionales; sin embargo, los jueces constitucionales no tienen legitimidad democrática de origen; ésta, se dice, se construye con las decisiones de los mencionados tribunales.

4) El principio de proporcionalidad como método privilegiado de la solución de conflictos entre los derechos, que no obstante, deslava, disminuye y relativiza el carácter fuerte de los derechos humanos.

5) Una pretensión o aspiración de globalización constitucional.

206 Ferrajoli, Luigi, Democracia y garantismo, Madrid, Trotta, 2010, pp. 303 y ss. 
Este libro forma parte del acervo de la Biblioteca Jurídica Virtual del Instituto de Investigaciones Jurídicas de la UNAM

El primer fundamento, las relaciones entre moral y derecho, es muy problemático. Algunos autores señalan la existencia de ese vínculo de manera fuerte - Dworkin y Alexy - , otros lo aceptan de manera débil - la mayoría de ellos - mientras que algunos lo rechazan tajantemente - Ferrajoli-. ¿Qué argumentan unos y otros?

La teoría de Dworkin tiene, entre uno de sus fines, criticar la tesis positivista de la discrecionalidad judicial. Para él, aún en los casos difíciles, sólo cabe una respuesta correcta. ¿Por qué? Porque ante un caso difícil el juez consulta a la moral y a la filosofía política si el sistema jurídico de entrada no brinda la solución. Dworkin piensa que el derecho no sólo se integra con las normas formalmente jurídicas sino que son parte del derecho también las normas morales y las teorías de la filosofía jurídica. Así, el juez interroga a estos vastos ordenamientos y a través de su racionalidad será capaz de encontrar los principios que mejor se adecuen al caso dentro de la tradición institucional de ese país, y que desde el punto de vista ético, ofrezcan la solución más justa. La coherencia de las resoluciones requiere de esquemas de prioridad entre los principios para los casos, pero ésta se obtiene a través de razonamientos objetivos y racionales. En Dworkin, la apelación a los principios morales para resolver los casos no es fuente de discrecionalidad, sino un fundamento de unidad, pues siempre es posible racionalmente, encontrar el principio moral adecuado al caso concreto si se tiene considerada la justeza de la decisión. El derecho en la concepción de Dworkin depende fuertemente de la moralidad que forma parte de lo jurídico. ${ }^{207}$

Dworkin está convencido de que existe una moralidad objetiva, independiente de nosotros, que es captada por nuestra racionalidad cuando adscribimos a un principio moral las propiedades o características adecuadas. Esta noción la explica a través de la diferenciación entre conceptos y concepciones. Los conceptos son contenidos morales no sujetos a discusión - absolutos-, en cambio, las concepciones obligan a un análisis racional para determinar en cada caso concreto cuál es el significado actual de un concepto, tomando en cuenta las circunstancias jurídicas y sociales vigentes; además de las prácticas interpretativas que mejor provean o se orienten a la solución más justa. Por ejemplo, el debido proceso es un concepto absoluto, que puede tener alcances y significados diversos, dependiendo del tiempo histórico, del contexto social y de la práctica social. Las concepciones del debido proceso pueden variar histórica y socialmente, pero el juez en cada

207 Dworkin, Ronald, El imperio de la justicia, op. cit., p. 193. 
Este libro forma parte del acervo de la Biblioteca Jurídica Virtual del Instituto de Investigaciones Jurídicas de la UNAM

momento escogerá de conformidad con la práctica jurídica la significación que sea más justa. ${ }^{208}$

Robert Alexy tiene una posición más matizada que Dworkin sobre las relaciones entre moral y derecho. Alexy está de acuerdo con Dworkin en la idea de que en los casos difíciles, el juez sólo tiene una única respuesta correcta. Sin embargo, la respuesta correcta es un fin al que se debe aspirar. Alexy no admite - como Dworkin - una teoría fuerte de los principios de forma que determine para cada caso la respuesta correcta. Su postura asume que los participantes en discurso jurídico argumentativo deben presuponer la respuesta correcta como idea regulativa - aquí encontramos una influencia grande de la ética discursiva de Habermas - 209 pero éstos nunca saben en qué casos lo lograrán, aunque deben hacer todo lo posible para alcanzarla. La teoría jurídica argumentativa de Alexy surge de una teoría previa de la argumentación moral, y no duda en la argumentación jurídica, que la argumentación moral es una forma o vía aplicable en la jurídica para la solución de los casos difíciles. ${ }^{210}$ Podemos decir que en Alexy, por la influencia de Habermas, la construcción de la ética que impacta en el derecho, es producto de un procedimiento discursivo que responde a las condiciones de un procedimiento deliberativo justo. La moralidad es un elemento ideal de corrección de la argumentación jurídica y del derecho.

Un buen número de autores, por ejemplo Luis Prieto Sanchís en nuestra lengua o Gustavo Zagrebelsky en Italia, ${ }^{211}$ aceptan la influencia de la moral en el derecho, pero su manera de entender ese vínculo se distancia del de Dworkin o Alexy. Para ellos, los conceptos morales están incorporados en las Constituciones y en los tratados, por lo que los actos de interpretación, aplicación y argumentación de los jueces, así como la actitud de los teóricos y dogmáticos del derecho, no pueden estimarse de neutralidad ni de simple conocimiento de los principios, sino que las autoridades asumen un punto de vista interno y fuerte con su derecho, de suerte que se acepta que la moral forma parte del derecho, lo que supone que no puede haber conocimiento jurídico sin compromiso con los principios y valores incardinados en el orden jurídico. Luis Prieto, quien recoge esta visión de manera crítica, así lo dice: “...el punto de vista interno es algo más que un género de aproxi-

208 Dworkin, Ronald, Los derechos en serio, op. cit., pp. 214-216.

209 Habermas, Jürgen, Problemas de legitimación en el capitalismo tardio, Buenos Aires, Amorrortu editores, 1973.

210 Alexy, Robert, Teoría de la argumentación jurídica, Madrid, Centro de Estudios Políticos y Constitucionales, 1989, p. 302; mismo autor, "Sistema jurídico, principios jurídicos y razón práctica", Revista Doxa, Alicante, núm. 5, 1988, pp. 148-151.

211 Zagrebelsky, Gustavo, El derecho dúctil. Ley, derechos, justicia, op. cit., pp. 114-126. 
Este libro forma parte del acervo de la Biblioteca Jurídica Virtual del Instituto de Investigaciones Jurídicas de la UNAM

mación al conocimiento, es un compromiso moral con las instituciones que describe y contribuye a construir; es la justificación de la presunta fuerza obligatoria del Derecho, que irremediablemente tiene carácter moral". ${ }^{212}$

Luigi Ferrajoli, por el contrario, no acepta una relación fuerte entre moral y derecho, ni comparte que la moral integre el punto de vista interno del derecho. Ferrajoli sí piensa que la moral crítica puede ser un elemento de cuestionamiento y de evaluación externa del derecho positivo, pero que ésta no está incardinada en el derecho, al positivarse pasa al ámbito de la juridicidad: cuando un principio moral se incorpora al derecho deja de ser moral para entenderse como principio jurídico positivado. La actitud tajante de separación entre moral y derecho que defiende Ferrajoli deviene del carácter crítico de su teoría garantista. Desde esa perspectiva, si aceptamos una íntima relación entre moral y derecho, entonces hay sobrados fundamentos para justificar todo orden jurídico; es decir, será correcto afirmar que se debe obediencia moral al derecho en todos los casos. Ferrajoli no comparte esa tesis porque el derecho y el Estado son construcciones artificiales que dependen de la política y de la correlación de fuerzas sociales, son creadas por los seres humanos, y en este sentido, los sistemas constitucionales no pierden en principio su carácter de ilegitimidad originaria con el fin de que los ciudadanos y autoridades puedan cuestionarlos constantemente. El jurista no puede ser complaciente con su orden jurídico aunque éste haya incorporado grandes valores y principios morales a sus normas, su disposición debe estar orientada a la crítica permanente, interna y externa, de ese orden jurídico y en la aplicación del mismo. ${ }^{213}$

La democracia constitucional es uno de los fundamentos filosóficos más importantes del Estado constitucional. Existe una forma distinta de entender la democracia. En el Estado del bienestar, la democracia se concibió como competencia entre elites para alcanzar el poder mediante la regla de las mayorías - la concepción pluralista o poliárquica- Para los teóricos del Estado constitucional la democracia no equivale al poder de la mayoría. La democracia es ante todo un arreglo institucional para garantizar los derechos fundamentales de los ciudadanos. ${ }^{214}$ No puede hablarse de democracia sin una protección fuerte, sustantiva, de los derechos. Las mayorías pueden violar derechos humanos de las minorías o de una persona, y por

212 Prieto Sanchís, Luis, "Sobre las relaciones entre el derecho y la moral: una crítica del constitucionalismo ético", en Prieto Sanchís, Luis, El constitucionalismo de los derechos. Ensayos de filosofia jurídica, Madrid, Trotta, 2013, p. 125.

213 Ferrajoli, Luigi, Principia iuris. Teoría del derecho y de la democracia, Madrid, Trotta, vol. 1, pp. 16 y 72.

214 Ferrajoli, Luigi, Derechos y garantías: La ley del más débil, Madrid, Trotta, 2010, p. 25. 
Este libro forma parte del acervo de la Biblioteca Jurídica Virtual del Instituto de Investigaciones Jurídicas de la UNAM

eso, no pueden ser equivalentes a la democracia. La democracia constitucional también nos previene en contra del concepto de soberanía, ésta no es asimilable ni a las mayorías ni a las unanimidades, tanto las mayorías como las unanimidades o las minorías son fragmentos de la soberanía. La soberanía termina o concluye cuando se postula; es una idea regulativa, que propone una noción de salvaguarda de los derechos de todos. La democracia constitucional constituye una limitación al poder de las mayorías. ${ }^{215}$

La concepción de democracia constitucional es un ideal complejo compuesto por dos ingredientes, uno relativo a la distribución del poder (quién y cómo decide), y otro concerniente a su limitación (qué no se puede decidir o dejar de decidir). El primero de los elementos lo podemos caracterizar como el derecho de todos los miembros del cuerpo político a participar en la toma de decisiones públicas, lo que implica que cada uno ha de disponer, directamente o por medio de sus representantes, del más amplio poder posible en cuanto a la determinación del resultado de esos procesos de decisión, exigencia que se satisface en parte con la regla de la mayoría. El segundo ingrediente es el del respeto de los derechos que garantizan la autonomía individual y los derechos sociales de las personas. ${ }^{216}$ En caso de conflicto o tensión entre los dos ingredientes, la regla de la mayoría puede ser derrotada a favor de la vigencia y prevalencia de un derecho fundamental. El binomio no guarda equilibrio, se decanta a favor de los derechos por encima de las reglas de la mayoría, aunque ésta sea la vía para poder decidir.

Gran parte de los autores del Estado constitucional recogen esta idea de democracia constitucional. Alexy sostiene que no se puede dejar en manos de la mayoría la garantía y protección de los derechos humanos. ${ }^{217}$ Ferrajoli expone que:

Ni siquiera por unanimidad puede un pueblo decidir (o consentir que se decida) que un hombre muera o sea privado sin culpa de su libertad, que piense o escriba, o no piense o escriba, de determinada manera, que no se reúna o no se asocie con otros, que se case o no se case con cierta persona o permanezca indisolublemente ligado a ella, que tenga o no tenga hijos, que haga o no haga tal trabajo u otras cosas por el estilo. La garantía de estos derechos

215 Salazar Ugarte, Pedro, La democracia constitucional: una radiografia teórica, Madrid, Fondo de Cultura Económica de España, 2007.

216 Bayón, Juan Carlos, "Democracia y derechos: problemas de fundamentación del constitucionalismo", en Carbonell, Miguel y García Jaramillo, Leonardo (coords.), El canon neoconstitucional, op. cit., pp. 285-355.

217 Alexy, Robert, Teoría de los derechos fundamentales, Madrid, Centro de Estudios Políticos y Constitucionales, 1993, p. 412. 
Este libro forma parte del acervo de la Biblioteca Jurídica Virtual del Instituto de Investigaciones Jurídicas de la UNAM

vitales es la condición indispensable de la convivencia pacífica. Por ello, su lesión por parte del Estado justifica no simplemente la crítica o el disenso, como para las cuestiones no vitales en las que vale la regla de la mayoría, sino la resistencia a la opresión hasta la guerra civil. ${ }^{218}$

Los guardianes de la democracia y del Estado constitucionales son los jueces constitucionales, que carecen de legitimidad democrática de origen porque no son electos, y que pueden expulsar definitivamente del sistema jurídico, normas que se oponen a la Constitución y/o a los tratados en contra de lo decidido por las mayorías legislativas. ${ }^{219}$ ¿Cómo resuelve el Estado constitucional el argumento contramayoritario?

La respuesta no es sencilla. Podemos comenzar diciendo que estos jueces deben poseer características especiales. Por eso, dice Joseph Raz, que las normas que se refieren a la independencia del poder judicial - métodos de designación de jueces, garantía de inamovilidad, procedimientos de fijación de salarios y otras condiciones de su función - están hechas para garantizar que los jueces procedan libres de presiones extrañas y sean independientes de toda autoridad, salvo la autoridad del derecho. Dichas normas son, por tanto, esenciales para preservar el Estado de derecho. ${ }^{220}$

Sin embargo, no bastan esas normas, suponiendo que existe la independencia de los jueces constitucionales respecto a los poderes formales y fácticos para salvaguardar el argumento contramayoritario - porque suelen ser designados por el poder político- Se requiere también, entre otras cosas, que tales jueces no tengan una influencia fuerte y autoritaria sobre el resto de la estructura judicial como la tienen en México, a través, entre otros medios, de la jurisprudencia obligatoria y de las facultades disciplinarias del Consejo de la Judicatura, que es presidido por el presidente de la Suprema Corte de Justicia de la Nación. Es decir, sería necesario que los jueces inferiores sirvieran de contrapeso deliberativo y social al poder de los jueces constitucionales - la jurisprudencia no debiera ser obligatoria-, ${ }^{221}$ que en muchos lugares no ocurre, y aunque se diese, tampoco sería una razón sólida contra el argumento contramayoritario, porque en casi todos los sis-

218 Ferrajoli, Luigi, Derecho y razón. Teoría del garantismo penal, Madrid, Trotta, 2009, p. 859.

219 Fioravanti dice que los jueces constitucionales lo hacen porque los legisladores y los políticos no tienen el coraje de hacerlo. Fioravanti, Maurizio, Constitucionalismo. Experiencias históricas y tendencias actuales, Madrid, Trotta, 2014, p. 153.

220 Raz, Joseph, La autoridad del derecho, México, UNAM, 1982, pp. 271 y 272.

221 Ansolabehere, Karina, La política desde la justicia. Cortes supremas, gobierno y democracia en Argentina y México, México, FLACSO-Fontamara, 2007, p. 124. 
Este libro forma parte del acervo de la Biblioteca Jurídica Virtual del Instituto de Investigaciones Jurídicas de la UNAM

temas jurídicos, la estructura judicial no es electa a través de procedimientos democráticos.

Así, el argumento contramayoritario queda sin resolver. ¿Por qué once personas no electas, suponiendo que son independientes y sensibles a los reclamos sociales, pueden invalidar leyes o porciones normativas que son aprobadas por las mayorías legislativas electas, bajo el argumento que defienden o garantizan derechos humanos, siendo que ellos además, determinan el significado y alcance de los derechos humanos?222

Autores como Ferrajoli, presuponen que los derechos humanos son derechos a favor de los más débiles, de las minorías, y por eso, se legitiman los tribunales constitucionales porque protegen y garantizan los derechos de los excluidos, ${ }^{223}$ pero esto no siempre es así en los países subdesarrollados o en vías de desarrollo. En nuestros países, las minorías suelen ser las personas con mayor poder económico, político, mediático o social, y no los más débiles o los excluidos del sistema socio-económico. Por eso, ese argumento no es aceptable. Al razonamiento que se recurre y que tiene mayor solvencia para superar el argumento contramayoritario, es que los jueces constitucionales tienen una representación argumentativa, lo que obliga a los tribunales constitucionales, en palabras de Alexy, a cumplir con dos condiciones fundamentales: 1) elaborar argumentos correctos y razonables, y 2) asumir que existen personas racionales - la sociedad, la comunidad académica, los medios de comunicación - dispuestas a aceptar argumentos correctos y razonables. ${ }^{224}$ De esta suerte, la legitimidad democrática de los jueces constitucionales descansaría en la corrección argumentativa que es aceptada o coincide con la mayor parte de la ciudadanía.

Carlos Nino, yendo un poco más allá, propone un mecanismo de reenvío del juez constitucional al legislador, para señalarle a éste que el proceso político de elaboración de la ley fue deficiente, y para mostrarle que se requieren condiciones de mayor participación y deliberación en la determi-

222 Bayón, Juan Carlos, "Democracia y derechos: problemas de fundamentación en el constitucionalismo", en Carbonell, Miguel y García Jaramillo, Leonardo (coords.), El canon neoconstitucional, op. cit., pp. 285-355; Ferreres Comella, Víctor, "El control judicial de la constitucionalidad de la ley. El problema de su legitimidad democrática", en Carbonell, Miguel y García Jaramillo, Leonardo (coords.), op. cit., pp. 356-380; Vázquez, Rodolfo, Derechos humanos. Una lectura liberal igualitaria, México, UNAM-ITAM-Centro de Estudios de Actualización en Derecho, 2015, pp. 129-161; y Cárdenas Gracia, Jaime, La argumentación como derecho, op. cit., pp. 155-199.

223 Ferrajoli, Luigi, "Pasado y futuro del Estado de derecho", en Carbonell, Miguel (ed.), Neoconstitucionalismo(s), op. cit., p. 28.

224 Alexy, Robert, "Ponderación, control de constitucionalidad y representación", en Cáatedra Ernesto Garzón Valdés 2004, México, Fontamara, 2005, pp. 102 y 103. 
Este libro forma parte del acervo de la Biblioteca Jurídica Virtual del Instituto de Investigaciones Jurídicas de la UNAM

nación del texto legal, sin que necesariamente exista un pronunciamiento sobre el fondo del asunto. En otras palabras, el juez constitucional interactuaría con el legislador en la búsqueda de razones o en el mejoramiento de las mismas. ${ }^{225} \mathrm{Al}$ igual que Ely, ${ }^{226}$ Nino piensa que los jueces constitucionales no deben ser los últimos custodios de los derechos, sino que es el proceso democrático — más deliberativo y participativo - el que debe ofrecer el escudo final frente a las violaciones de tales derechos. Gargarella, en este tenor, propone reformas al juez constitucional para que éste obtenga legitimidad democrática: 1) introducir el reenvío al legislador para que el juez constitucional no tenga la última palabra; 2) estrechar la vinculación entre las minorías sociales y el juez constitucional a través de nuevos medios de derecho procesal constitucional, y 3) una reforma política que acompañe a la reforma judicial para promover un modelo más participativo y deliberativo, más transparente y orientado a la sociedad. ${ }^{227}$

Un fundamento jurídico filosófico del Estado constitucional es el método o regla privilegiada que utilizan los jueces constitucionales, y que sirve para resolver los conflictos entre derechos y principios constitucionales: el principio de proporcionalidad. ¿En qué consiste este método? Es un procedimiento para interpretar y argumentar principios constitucionales cuando, ante situaciones jurídicas de colisión, se hace necesario determinar cuál de los principios constitucionales en conflicto debe prevalecer. ${ }^{228}$ Lato sensu comprende tres subprincipios: idoneidad, necesidad y proporcionalidad en sentido estricto. Es obvio que en stricto sensu, sólo atendemos al tercero de los subprincipios. Cuando la teoría jurídica y la jurisprudencia aluden al principio de proporcionalidad, lo hacen lato sensu y cuando se refieren al tercer subprincipio indican que es en estricto sentido. ${ }^{229}$

Robert Alexy dice que los tres subprincipios expresan la idea de optimización; lo que significa que interpretar los derechos fundamentales, de acuerdo con el principio de proporcionalidad, es tratar a éstos como requi-

225 Nino, Carlos, Fundamentos de derecho constitucional, análisis jurídico y politológico de la práctica constitucional, Buenos Aires, Astrea, 1992, pp. 657 y ss.

226 Ely, John, Democracy and Distrust. A Theory of Fudicial Review, Cambridge, Harvard University Press, 1980.

227 Gargarella, Roberto, La justicia frente al gobierno. Sobre el carácter contramayoritario del poder judicial, Barcelona, Ariel, 1996, pp. 173 y ss.; mismo autor, "¿Los partidarios de la democracia deliberativa deben defender la protección judicial de los derechos sociales?", en Arango, Rodolfo (ed.), Filosofia de la democracia. Fundamentos conceptuales, Bogotá, Siglo del Hombre Editores-Universidad de los Andes-Ceso, 2007, pp. 393 y 394.

228 Cárdenas Gracia, Jaime, Manual de Argumentación jurídica, op. cit., pp. 189-220.

229 Clérico, Laura, El examen de proporcionalidad en derecho constitucional, Buenos Aires, Eudeba, 2009, pp. 39-161. 
Este libro forma parte del acervo de la Biblioteca Jurídica Virtual del Instituto de Investigaciones Jurídicas de la UNAM

sitos de optimización. Es decir, como principios y no como reglas. Los principios son normas que requieren que algo se realice con la mayor amplitud posible dentro de las posibilidades jurídicas y fácticas. ${ }^{230}$ Los subprincipios de idoneidad y de necesidad se refieren a la optimización vinculada a las posibilidades fácticas. El subprincipio de proporcionalidad en sentido estricto alude a la optimización de los derechos fundamentales dentro de sus posibilidades jurídicas.

Los tres subprincipios que componen el principio de proporcionalidad en un sentido lato pueden analizarse en abstracto y en concreto cuando se trata de afectaciones en los derechos fundamentales por acción o por omisión de las autoridades. Casi siempre se suele explicar el principio de proporcionalidad por las intervenciones de las autoridades que afectan derechos fundamentales por sus acciones y muy poco por las omisiones e insuficiencias de las autoridades en la protección o garantía de los derechos fundamentales.

Desde el punto de vista de la afectación mediante acciones de la autoridad, definimos así los tres subprincipios:

1) El de idoneidad entraña que toda intervención ${ }^{231}$ legislativa o de autoridad sobre un derecho fundamental, para que sea correcta, debe ser adecuada para contribuir a la obtención de un fin constitucionalmente legítimo.

2) El de necesidad significa que la intervención sobre un derecho fundamental, para que sea correcta, debe ser la más benigna — la que le afecte menos - de entre todas las posibles medidas de intervención.

3) El de proporcionalidad en estricto sentido, o ley de ponderación, precisa que la intervención en un derecho fundamental sólo se justifica por la importancia de la intervención de la autoridad para satisfacer otro derecho fundamental o principio; es decir, debe ser de tanto peso o trascendencia esa intervención para satisfacer otros derechos o principios, que la afectación o insatisfacción al derecho fundamental quede compensada por la importancia de la satisfacción del otro derecho fundamental o principio satisfecho.

230 Alexy, Robert, "Ponderación, control de constitucionalidad y representación", en Andrés Ibañez, Perfecto y Alexy, Robert, fueces y ponderación argumentativa, México, UNAM, 2006, p. 2.

231 El concepto de intervención es una noción neutra que se prefiere a expresiones como violación, vulneración, conculcación, invalidez, etcétera. La intervención legislativa o de otra autoridad en un derecho fundamental sólo será considerada inconstitucional después de que aplique el principio de proporcionalidad y se estime indebida la intervención. 
Este libro forma parte del acervo de la Biblioteca Jurídica Virtual del Instituto de Investigaciones Jurídicas de la UNAM

Desde el punto de vista de la afectación de derechos fundamentales, mediante omisiones o acciones insuficientes de la autoridad - lo que es muy importante en materia de derechos económicos, sociales, culturales y ambientales-, podemos definir así los tres subprincipios:

1) El de idoneidad nos dirá que la omisión o actuación insuficiente de la autoridad en la protección o garantía de los derechos fundamentales es correcta si contribuye a la obtención de algún otro fin constitucionalmente legítimo.

2) El de necesidad entraña que la omisión o actuación insuficiente de la autoridad es correcta si produce consecuencias más benignas que su intervención activa.

3) El de proporcionalidad en sentido estricto debe implicar que la omisión o actuación insuficiente de la autoridad que afecta derechos fundamentales - para que sea correcta - quede compensada por la importancia que éstas tienen para la satisfacción de otro u otros derechos fundamentales o principios satisfechos.

Se puede decir que la teoría discursiva de Alexy basada en reglas, principios y procedimientos - especialmente el principio de proporcionalidad-, produce una teoría del derecho que genera un jurista que debe estar atento al derecho injusto y que debe al mismo tiempo denunciarlo para que pueda imponerse el verdadero derecho. Es una teoría que favorece las actividades de resistencia frente al derecho injusto que no provocaría una concepción positivista tradicional o formalista del derecho. No obstante, hay quien opina que se trata de una teoría conservadora porque la pretensión de corrección en el derecho infravalora logros históricos como la lucha por el Estado de derecho y no facilita cambios en el sistema normativo, esto es, concluye en una teoría legitimadora del status quo porque el principio de proporcionalidad tiene como fin equilibrar los intereses contrapuestos que existen en la sociedad, sin modificar los modos y formas de producción capitalista. ${ }^{232}$

Finalmente, existe como fundamento filosófico-jurídico del Estado constitucional, la pretensión de extender las bondades de esta forma de Estado al mundo globalizado. El autor de esta corriente que se ha atrevido a formular cambios en la esfera global es Ferrajoli. ${ }^{233}$ Según este autor, las realidades

232 García Figueroa, Alfonso, Principios y positivismo jurídico, Madrid, Centro de Estudios Políticos y Constitucionales, 1998, pp. 408 y 409.

233 Existen otros como Atienza o Prieto Sanchís, que ven con preocupación el impacto de la globalización, pero no avanzan lo suficiente en sus propuestas. Atienza, Manuel, "Consti- 
Este libro forma parte del acervo de la Biblioteca Jurídica Virtual del Instituto de Investigaciones Jurídicas de la UNAM

del modelo globalizador sólo pueden enfrentarse con un nuevo paradigma jurídico, el que tendrá que basarse en tres elementos: la limitación jurídica de todos los poderes supranacionales y estatales; la garantía de la paz a nivel mundial y nacional, y por medio de un reforzamiento y ampliación de los derechos humanos en todas las instituciones y organizaciones relevantes de las sociedades nacionales e internacionales, incluyendo a las grandes corporaciones económicas. ${ }^{234}$

Sin embargo, el planteamiento de Ferrajoli tiene, desde mi punto de vista, un flanco muy débil que es común a todas las teorías de su tipo. La concepción de la llamada democracia constitucional ferrajoliana desdeña el papel de las mayorías, del pueblo. Ferrajoli considera que el poder de las mayorías desemboca en construcciones fascistas, y por eso, los derechos humanos no deben pertenecer al ámbito de la democracia, forman parte de un ámbito no sujeto al regateo, a la negociación o a la discusión de las mayorías. El alcance de los derechos, su extensión y sus garantías de protección no son parte de la deliberación democrática. Los derechos humanos pertenecen al ámbito de lo indecidible para las mayorías. El pueblo soberano no puede en contra de los derechos humanos de las minorías o aún respecto a los derechos humanos de una sola persona. ${ }^{235}$

En nuestro tiempo y para tener la capacidad de lucha y oposición a la globalización, debemos comenzar por reconocer, como lo hace Ferrajoli, lo siguiente: 1) que los derechos humanos siguen siendo una promesa no realizada en muchos lugares del mundo, principalmente los derechos económicos, sociales y culturales y ambientales, y que esa ineficacia de los derechos tiene que ver fundamentalmente con las características del modelo económico neoliberal que no está interesado en el desarrollo de sociedades libres e igualitarias; 2) que las soberanías de los Estados son profundamente desiguales, que existen soberanías casi absolutas como la de Estados Unidos frente a las soberanías de los demás Estados, y que entre las soberanías de los Estados, existen niveles y grados diversos de desigualdad; 3) que las ciudadanías también están desequilibradas, pues existen ciudadanos optimo iure con todos los derechos y semiciudadanos con permisos de residencia, refugiados, irregulares y clandestinos; situaciones jurídicas que en el mundo globalizado son fuente de exclusión y de discriminación entre las personas;

tucionalismo, globalización y derecho", en Carbonell, Miguel y García Jaramillo, Leonardo (coords.), El canon neoconstitucional, op. cit., pp. 264-281; Prieto Sanchís, Luis, El constitucionalismo de los derechos. Ensayos de filosofia jurídica, op. cit., pp. 225 y ss.

234 Ferrajoli, Luigi, Principia iuris. Teoría del derecho y de la democracia, Madrid, Trotta, vol. 2, 2011, p. 471.

235 Ibidem, p. 478. 
Este libro forma parte del acervo de la Biblioteca Jurídica Virtual del Instituto de Investigaciones Jurídicas de la UNAM

4) que las normas y las instituciones del derecho internacional son aún muy débiles e imperfectas, tanto desde sus ilegitimidades democráticas de origen y de ejercicio, como de las vías para exigir su acatamiento, pues en el ámbito supranacional aún nos encontramos, en muchos sentidos, en un estado de naturaleza hobbesiano, en el que, por un lado, hay ausencia o imperfección de reglas, y por otro, existencia de la influencia de los más poderosos, sean las grandes potencias o los intereses económicos más relevantes, los que imponen la ley del más fuerte, y 5) que no hemos ideado hasta el momento un derecho internacional que traslade los fines del constitucionalismo a la esfera mundial y que el propio constitucionalismo nacional recibe los embates de la globalización. ${ }^{236}$

Para hacer frente a las características nocivas de la globalización, Ferrajoli desbroza sus propuestas. Así, insiste en: 1) un constitucionalismo mundial que prohíje un federalismo global multinivel, en donde los ordenamientos nacionales e internacionales estén coordinados de suerte que se limite cualquier poder arbitrario, se garanticen los derechos humanos y se preserve la paz; 2) los derechos civiles de autonomía que dan fundamento al mercado deben quedar subordinados a los derechos humanos, tanto de libertad como a los de carácter social; 3) la orientación de todo derecho debe estar enmarcado en la garantía de la paz y de los derechos humanos; 4) las funciones de garantía de los derechos humanos, tanto nacionales como internacionales, deben subordinar cualquier acción de gobierno nacional e internacional que se pretendan colocar por encima de ellas, y 5) se deben articular las competencias de nivel federal mundial con las estatales, de suerte que se produzca un nuevo federalismo cooperativo, capaz de subordinar la economía al derecho, a través, entre otras medidas, de la democratización y perfeccionamiento jurídico de las actuales instituciones internacionales. ${ }^{237}$

Sin embargo, esas propuestas y otras, son irrealizables si no se modifican las hoy dominantes bases económicas de la globalización. En las condiciones actuales del neoliberalismo, la extensión del constitucionalismo a las esferas supranacionales es impensable. La debilidad mayor del Estado constitucional y de sus teóricos, es haber elaborado una concepción del Estado sin asideros en los sistemas económicos, sociales e ideológicos que conforman la hegemonía mundial. Así, el Estado constitucional debe ser visto como una construcción jurídica que puede funcionar prevalentemente en

236 Ibidem, pp. 480-485.
237 Ibidem, pp. 540-544. 
Este libro forma parte del acervo de la Biblioteca Jurídica Virtual del Instituto de Investigaciones Jurídicas de la UNAM

lo que queda de los Estados-nación pero no en el mundo globalizado, y que además, carece de respaldos provenientes de otras disciplinas y ciencias.

\section{EL MODELO JURÍDICO DEL ESTADO CONSTITUCIONAL}

Existen diversas caracterizaciones del modelo jurídico del Estado constitucional. Si seguimos a Guastini, podemos mencionar las siguientes: a) una constitución rígida; $b$ ) la garantía jurisdiccional de la Constitución; $c$ ) la fuerza vinculante de la Constitución; d) la sobreinterpretación de la Constitución; e) la aplicación directa de las normas constitucionales; $f$ ) la interpretación conforme de las leyes, $\mathrm{y} g$ ) la influencia de la Constitución sobre las relaciones políticas. ${ }^{238}$

La Constitución rígida entraña dos cuestiones: que en la Constitución existen principios expresos e implícitos que no pueden ser modificados ni siquiera por una reforma constitucional, y que la Constitución constitucionaliza o irradia al resto del ordenamiento jurídico.

En cuanto a la garantía jurisdiccional de la Constitución, ello conlleva que la Constitución y los tratados sobre derechos humanos se protegen mediante el control jurisdiccional de constitucionalidad y convencionalidad por tribunales nacionales y supranacionales, y a través de las distintas vías de control de constitucionalidad y convencionalidad que están previstas en cada sistema jurídico y cada tratado.

La fuerza vinculante de la Constitución significa que todas las normas de la Constitución son obligatorias para todas las autoridades del Estado. No son programas de acción política ni recomendaciones; las autoridades de los distintos niveles del Estado están obligadas a acatarlas.

En el Estado constitucional, la Constitución se sobreinterpreta; es decir, no se acude a los métodos tradicionales de interpretación de las normas como el gramatical, más bien los contenidos de las normas constitucionales extienden todos los significados posibles para optimizar la protección de los derechos humanos y los principios democráticos. La sobreinterpretación de la Constitución impacta en las relaciones de los gobernados con los poderes públicos, pero también en las relaciones entre los particulares.

Existe aplicación directa de la Constitución, de lo que se deduce por lo menos dos situaciones: a) la Constitución rige para los particulares y no sólo

238 Guastini, Riccardo, Estudios de teoría constitucional, México, Fontamara-UNAM, Instituto de Investigaciones Jurídicas, 2007, p. 153; Carbonell, Miguel, "El neoconstitucionalismo: significado y niveles de análisis", en Carbonell, Miguel y García Jaramillo, Leonardo, (coords.), El canon neoconstitucional, op. cit., pp. 153-164. 
Este libro forma parte del acervo de la Biblioteca Jurídica Virtual del Instituto de Investigaciones Jurídicas de la UNAM

para los poderes públicos, y $b$ ) todas las autoridades deben aplicar la Constitución, aunque no exista ley secundaria de desarrollo con el propósito de salvaguardar derechos humanos y principios democráticos.

La interpretación conforme, que recoge el segundo párrafo del artículo 1o. de nuestra Constitución, se vincula a que todas las normas del ordenamiento secundario deben interpretarse a partir de lo establecido en la Constitución, lo que es tarea de todas las autoridades. También significa que en caso de posibles interpretaciones opuestas, debe preferirse la que sea más consecuente con los principios de la Constitución.

En cuanto a la influencia política de las Constituciones en las relaciones políticas, ello tiene que ver con tres cuestiones: a) La existencia de métodos constitucionales para resolver conflictos entre poderes y órganos -la controversia constitucional-; b) la imposibilidad de que existan decisiones de autoridad sin la consecuente revisión de constitucionalidad, y c) los sujetos políticos deben orientar su acción política hacia la maximización de los principios constitucionales. En fin, toda la vida pública y privada está bajo el paraguas de la Constitución y de los tratados sobre derechos humanos.

Luis Prieto Sanchís elabora para el Estado Constitucional el siguiente modelo:

Primero, carácter normativo o fuerza vinculante. La Constitución no es un catecismo político o una guía moral dirigida al legislador virtuoso, sino una norma como cualquier otra que incorpora la pretensión de que la realidad se ajuste a lo que ella prescribe. Segundo, supremacía o superioridad jerárquica en el sistema de fuentes. La Constitución no es sólo una norma, sino que es la norma suprema y ello significa que condiciona la validez de todos los demás componentes del orden jurídico y que representa frente a ellos un criterio de interpretación prioritario. Tercero, eficacia o aplicación directa. En consecuencia de lo anterior, si la Constitución es una verdadera norma suprema ello supone que no requiere la disposición de ningún otro acto jurídico - singularmente de una ley - para desplegar su fuerza vinculante; por eso, en la medida que los preceptos constitucionales sean relevantes en un proceso cualquiera, su aplicación resultará obligada. Cuarto, garantía judicial. Como sabemos... las posibilidades son muy amplias: control concreto y abstracto, $a$ priori o a posteriori, encomendado a los jueces superiores o a los jueces ordinarios. Pues bien, con independencia de que resulten viables distintas formas de articulación, creo que un rasgo típico del constitucionalismo contemporáneo es la competencia que corresponde a los jueces ordinarios para que resuelvan a la vista de todo el ordenamiento jurídico, incluida por tanto la Constitución. Quinto, presencia de un denso contenido normativo que tiene como destinatarios a los ciudadanos en sus relaciones con el poder y también con 
Este libro forma parte del acervo de la Biblioteca Jurídica Virtual del Instituto de Investigaciones Jurídicas de la UNAM

las modulaciones que requieran y que nacen de la propia Constitución, en sus relaciones horizontales de derecho privado; contenido normativo que está formado por principios, derechos y directrices, más o menos precisos, pero siempre que resulten relevantes, están llamados a su aplicación en los casos concretos. Y en sexto y último lugar, la rigidez constitucional. No cabe duda de que el constitucionalismo resulta tanto más fuerte como más costosa es la alteración del texto, cuando más inaccesible se muestre frente a las mayorías legislativas...239

Por mi parte estimo, a la luz de lo que en estas páginas hemos comentado y descrito, que las notas fundamentales del Estado Constitucional son:240

1) Conexión en diversos grados, según el autor y corriente, entre el derecho y la moral.

2) Los derechos humanos son el fundamento y el fin del Estado y el derecho.

3) Las Constituciones expresan principios y proyectos jurídicos y políticos contrapuestos. Ninguno prevalece a priori sino en la aplicación de los casos concretos.

4) Reconocimiento de que el derecho está conformado por multitud de materiales normativos, fundamentalmente por reglas, principios y valores.

5) Orientación hacia la Constitución normativa; es decir, a la unión entre el deber ser de la norma y la realidad.

6) El derecho no sólo consiste en una estructura normativa, sino también argumental, contextual y procedimental.

7) La legalidad y el resto de las fuentes jurídicas se supedita a la convencionalidad y a la constitucionalidad en un sentido fuerte.

8) Las normas que no son reglas no se pueden interpretar por los métodos tradicionales. Es preciso acudir al principio de proporcionalidad y a otras formas de argumentación para resolver las colisiones entre principios opuestos.

9) El ordenamiento jurídico se interpreta desde la Constitución para maximizar los derechos fundamentales.

10) La certeza jurídica se vuelve más exigente y difícil; se apoya, principalmente en la calidad de la argumentación.

239 Prieto Sanchís, Luis, Fusticia constitucional y derechos fundamentales, Madrid, Trotta, 2003, pp. 116 y 117.

240 Cárdenas Gracia, Jaime, La argumentación como derecho, op. cit., pp. 51 y 52. 
Este libro forma parte del acervo de la Biblioteca Jurídica Virtual del Instituto de Investigaciones Jurídicas de la UNAM

11) La Constitución es una norma directamente aplicable por todas las autoridades y rígida. Existen principios que no pueden reformarse utilizando el procedimiento constitucional de revisión constitucional.

12) El juez constitucional es el garante del Estado constitucional y carece de legitimidad democrática de origen. La busca suplir a través de la calidad argumentativa de sus resoluciones.

13) Se pretende globalizar el constitucionalismo, pero sin éxito, porque el Estado constitucional no tiene una teoría económica que le otorgue fundamento.

14) La democracia constitucional no se origina en la regla de la mayoría, sino en el respeto y garantía de los derechos humanos. Las mayorías son un fragmento de la soberanía popular.

15) Se trata de un Estado que no es neutral ni avalorativo. Su ideología es la de los principios y valores contrapuestos que se contienen en la Constitución y en los tratados sobre derechos humanos. Sin embargo, éstos no siempre son realizados, principalmente los que expresan derechos económicos, sociales, culturales y ambientales.

\section{LAS GRÍTICAS AL ESTADO GONSTITUCIONAL}

El Estado constitucional es una construcción exclusivamente jurídica, ideada por dogmáticos y por los tribunales constitucionales. Como tal, presenta muchas deficiencias sobre las que no me voy a pronunciar. Una de ellas que excluyo, y que es muy problemática, por la diversidad de puntos de vista dentro del neoconstitucionalismo, es la de las relaciones entre moral y derecho. Sin eludir el problema, considero que esa relación existe, aunque en un sentido débil, crítico y deliberativo, sobre todo cuando los principios y valores de la Constitución y de los tratados sobre derechos humanos y principios democráticos, son expresión de concepciones morales que se han positivado. Cuando aludimos a la moral y sus vínculos con el derecho, no estamos pensando en la moral objetiva fuerte, según el punto de vista de autores como Dworkin -que sostiene que la moralidad es externa al ser humano y sólo debemos conocerla e incorporarla a nuestros razonamientos morales y jurídicos-, pues aunque aceptamos que existen elementos morales que se desprenden de nuestra naturaleza biológica y psíquica, lo fundamental es que lo que estimamos como moral sea consecuencia de un proceso deliberativo y discursivo en el seno de la sociedad bajo reglas de imparcialidad. La moralidad no puede entenderse sin pasar por la prueba de la racionalidad discursiva de carácter colectivo, y sin que se entienda su evolución y alcances desde contextos histó- 
Este libro forma parte del acervo de la Biblioteca Jurídica Virtual del Instituto de Investigaciones Jurídicas de la UNAM

ricos y culturales concretos. De esta suerte, la moralidad que importa socialmente y jurídicamente - la ética - tiene a nuestro juicio tres componentes: a) la naturaleza biológica y psíquica del ser humano; $b$ ) los procedimientos discursivos - bajo condiciones democráticas, de transparencia y simetríade carácter social, político y jurídico, sobre los principios que se promuevan como éticamente aceptables en el seno de una sociedad particular y que se incorporan posteriormente al orden jurídico y a las resoluciones de los tribunales, y c) los fundamentos históricos y culturales, que propician la deliberación y la participación en el discurso colectivo, a partir de las necesidades e intereses humanos.

Las deficiencias y críticas del Estado constitucional que exploro en esta parte del ensayo son las siguientes: 1) las teorías del Estado constitucional prescinden de las condiciones económicas vigentes y de las teorías económicas que las analizan; 2) las teorías del Estado constitucional eluden una teoría sobre el poder que dé cuenta del papel contemporáneo de los poderes fácticos, de la hegemonía cultural, ideológica y mediática, así como de la organización y diseño del poder formal; 3) las teorías del Estado constitucional descuidan formas de organización social y democrática relacionadas con la democracia participativa y deliberativa, así como con las manifestaciones de la democracia comunitaria, es decir, no advierten las capacidades transformadoras de una democracia radical que haga viables los fines del Estado constitucional; 4) las teorías del Estado constitucional son poco exigentes con realidades contemporáneas como la plurinacionalidad y el multiculturalismo; 5) aunque existen autores que se han preocupado por la globalización del constitucionalismo, las teorías del Estado constitucional no abundan sobre las ventajas, desventajas y posibilidades que para el constitucionalismo tiene la globalización; 6) las teorías del Estado constitucional, con su concepto de democracia constitucional, favorecen la posición de los más privilegiados del sistema y no la de las minorías menos aventajadas; 7) las teorías del Estado constitucional presentan rasgos profundamente elitistas: las élites burocráticas supranacionales definen el sentido y alcance de los derechos humanos; 8) los guardianes del Estado constitucional - los jueces constitucionales - no poseen legitimidad democrática de origen; 9) el principio de proporcionalidad, método privilegiado para resolver los conflictos entre principios constitucionales, no sólo deslava a los derechos humanos, sino que es un método que mantiene el status quo, y 10) las teorías del Estado constitucional son una ficción jurídica sin asideros en la realidad. Son una inspiración, un noble sueño, aunque reconozco que pueden poseer capacidades transformadoras. 
Este libro forma parte del acervo de la Biblioteca Jurídica Virtual del Instituto de Investigaciones Jurídicas de la UNAM

El Estado del bienestar tuvo una base económica: la del keynesianismo. El Estado constitucional no tiene ninguna - tampoco se preocupa por elaborarla-, y como sabemos, la materialización de los derechos humanos, sobre todo los económicos, sociales, culturales y ambientales, exigen de una base económica. Los derechos de igualdad se pueden reconocer en las constituciones; pero eso no basta, es necesario que tengan vigencia en la facticidad. El modelo económico dominante en las sociedades es determinante para ese fin. Si el modelo económico no promueve condiciones de pleno empleo, de distribución de la riqueza, de fortaleza de los mercados internos, de fiscalidad progresiva, de amplio gasto social, de organizaciones empresariales basadas en la cogestión, o al menos, en la intervención de los trabajadores en la determinación de las inversiones, si no se garantiza la independencia de los sindicatos, si la política económica no tiene orientación social, etcétera, la Constitución y los tratados pueden reconocer los derechos que estimen convenientes, ya que su realización será imposible o muy incierta.

De esta suerte, la justiciabilidad, protección y eficacia de los derechos económicos, sociales, culturales y ambientales, precisa de algunas metas económicas básicas para su consecución, entre otras, las siguientes:

1) Incremento sustancial y autosustentable del producto nacional per cápita; 2) Distribución equitativa del ingreso nacional; 3) Sistemas impositivos adecuados y equitativos; 4) Modernización de la vida rural y reformas que conduzcan a regímenes equitativos y eficaces de tenencia de la tierra, mayor productividad agrícola, expansión del uso de la tierra, diversificación de la producción y mejores sistemas para la industrialización y comercialización de productos agrícolas; 5) Industrialización acelerada y diversificada, especialmente de bienes de capital intermedios; 6) Estabilidad del nivel de precios internos en armonía con el desarrollo; 7) Salarios justos, oportunidades de empleo y condiciones de trabajo aceptables para todos; 8) Erradicación rápida del analfabetismo y ampliación para todos de oportunidades en el campo de la educación; 9) Defensa del potencial humano mediante la extensión y aplicación de los modernos conocimientos de la ciencia médica; 10) Vivienda adecuada para todos los sectores de la población; 11) Condiciones urbanas que hagan posible una vivienda sana, productiva y digna; 12) Promoción de la iniciativa y la inversión privada en armonía con la acción del sector público, y 13) Expansión y diversificación de las exportaciones. ${ }^{241}$

241 Hernández, Armando, Los derechos económicos, sociales, culturales y ambientales en el nuevo modelo constitucional de derechos humanos en México, México, Comisión Nacional de los Derechos Humanos, 2015, pp. 49 y 50. 
Este libro forma parte del acervo de la Biblioteca Jurídica Virtual del Instituto de Investigaciones Jurídicas de la UNAM

Esas condiciones hoy en día no existen, el modelo económico dominante no es keynesiano, es neoliberal; se caracteriza por apostar por la economía irrestricta del mercado y por un Estado que intervenga, no para enfrentar las desigualdades sociales y económicas que provoca el mercado como lo hacía el keynesianismo, sino para salvaguardar y extender la presencia del mercado, para garantizar su buen funcionamiento y para enfrentar las barreras e impedimentos regulatorios a la libre competencia. ${ }^{242}$ Las medidas económicas del neoliberalismo consisten en desregular la economía, liberalizar el comercio y la industria y privatizar las empresas estatales. Específicamente sus tendencias económicas se distinguen por lo siguiente:

- Desmantelamiento de las regulaciones que existían sobre diferentes actividades, destacando, entre otras, a las financieras, las que asumen un rol fundamental en la orientación de las actividades productivas.

- Debilitamiento de la posición negociadora del trabajo mediante distintas desregulaciones y acotamientos de las relaciones obreropatronales.

- Estrechamiento financiero y reglamentario en la prestación de servicios de bienestar social.

- Reorganización de las actividades productivas para reducir costos, incluyendo la introducción de innovaciones tecnológicas, la reducción de las plantillas laborales y la relocalización geográfica de porciones importantes de los procesos productivos o de actividades completas.

- Reducción del déficit fiscal, dejando el peso para lograrlo sobre el gasto del gobierno, como consecuencia de las acciones de desgravación impositiva.

- Privatización de empresas públicas y privatización de servicios públicos al igual que la subcontratación de actividades como parte de la provisión de servicios públicos.

- Política macroeconómica centrada en la estabilidad de precios y abandono de la política fiscal macroeconómica que anteriormente, en el modelo keynesiano, servía para redistribuir la riqueza.

- Liberalización de los flujos de comercio y capital entre países. ${ }^{243}$

242 Steger, Manfred B. y Roy, Ravi K., Neoliberalismo. Una breve introducción, Madrid, Alianza, 2011, pp. 29-34.

243 Pikkety, Thomas, El capital en el siglo XXI, México, Fondo de Cultura Económica, 2014, pp. 129 y ss.; mismo autor, La crisis del capital en el siglo XXI. Crónicas de los años en que el capitalismo se volvió loco, México, Siglo XXI Editores, 2015, pp. 99 y ss. 
Este libro forma parte del acervo de la Biblioteca Jurídica Virtual del Instituto de Investigaciones Jurídicas de la UNAM

Tal vez sea pedirle mucho a la teoría del Estado constitucional para que desarrolle un modelo económico compatible con sus tesis principales, pero al menos sus autores relevantes debieran ser conscientes de que la teoría jurídica que han construido no descansa en bases económicas sólidas. Es verdad que el modelo económico neoliberal o neoclásico hoy imperante puede modificarse - de hecho está en una profunda crisis mundial-. ${ }^{244}$ Sin embargo, para que el Estado constitucional fuese posible sería necesario que existiesen condiciones económicas semejantes a las que se tuvieron durante el esplendor o consolidación del Estado del bienestar; de preferencia, debieran buscarse otros caminos económicos que fueran construyendo esquemas de análisis económico que propiciaran modos y relaciones de producción cercanas al socialismo democrático.

No comparto y tampoco acepto, como lo hace Antonio Negri, que la concepción teórica que hoy tenemos sobre los derechos humanos, de libertad y de igualdad, sólo sea posible dentro de los límites del desarrollo capitalista en su fase actual. ${ }^{245}$ La legitimidad del Estado no pude basarse en la regla capitalista de explotación de unos sobre otros, en donde, como hoy lo explican teóricos tan notables como Stiglitz o Bauman, ${ }^{246}$ el capitalismo mundial favorece a una limitadísima minoría frente a la gran mayoría empobrecida. Quiero creer que otras vías y alternativas son posibles, aunque como señala Bauman:

...gracias a la nueva "porosidad" de las economías presuntamente nacionales, los mercados financieros globales, en virtud del carácter esquivo y extraterritorial del espacio en que operan, imponen sus leyes y preceptos sobre el planeta... Los Estados carecen de los recursos o el margen de maniobra para soportar la presión, por la mera razón de que unos minutos bastan para que se derrumben empresas o incluso Estados. ${ }^{247}$

Otra deficiencia importante del Estado constitucional es su visión acerca del poder. El acento de las teorías del Estado constitucional está puesto en los derechos humanos. Los principios democráticos y la organización

\footnotetext{
244 Wallerstein, Immanuel et al., ¿Tiene futuro el capitalismo?, México, Siglo XXI Editores, 2015.

245 Negri, Antonio, La forma-Estado, Madrid, Akal, 2003, pp. 386 y 387.

246 Stiglitz, Joseph E., El malestar en la globalización, Madrid, Santillana, 2002, pp. 51-80; Bauman, Zygmunt, La globalización. Consecuencias humanas, México, Fondo de Cultura Económica, 2015, pp. 13-38.

247 Bauman, Zygmunt, La globalización. Consecuencias humanas, op. cit., p. 89.
} 
Este libro forma parte del acervo de la Biblioteca Jurídica Virtual del Instituto de Investigaciones Jurídicas de la UNAM

del poder formal y fáctico juegan un papel menos importante, diríamos secundario. En esas teorías constitucionales no encontramos con suficiente profundidad — tal vez con la excepción de Ferrajoli—248 un análisis sobre el rol que los poderes fácticos o salvajes desempeñan en el constreñimiento de los derechos humanos. Hoy, los derechos humanos se ven amenazados por esos poderes no regulados que existen a nivel planetario y nacional, que imponen sus lógicas y sus intereses por encima de los derechos de las personas. Las teorías del Estado constitucional no pueden seguir explicando al Estado exclusivamente desde los esquemas de los poderes formales, sino que deben advertir que los poderes fácticos tienen la capacidad de dinamitar - porque no existen desarrollados por las teorías constitucionales los controles políticos y jurídicos suficientes - todos los postulados y las tesis del Estado constitucional. En el mismo sentido, es de resaltar la poca atención que la teoría del Estado constitucional brinda al concepto gramsciano de hegemonía, y cómo este concepto y sus manifestaciones ideológicas, religiosas, filosóficas y mediáticas, respaldan las nociones y categorías hegemónicas de los intereses más poderosos del mundo, y cómo las narrativas alternativas a favor de los derechos y la democracia, tienen poca cabida y espacio en el mundo social, político y económico de nuestro tiempo. La hegemonía respalda claramente al neoliberalismo y no al Estado constitucional. ${ }^{249}$

En el pensamiento gramsciano, el Estado representa la expresión de una hegemonía ideológica que se ha impuesto a las demás y que en este momento histórico sirve al capitalismo. ${ }^{250}$ Esa hegemonía dota de legitimidad transitoria a las instituciones y gobernantes, y puede ser sustituida por nuevas hegemonías si éstas tienen la capacidad de imponerse. Gramsci concibe al Estado como un modelo de dominación capitalista que está en permanente cuestionamiento por legitimidades o hegemonías emergentes. ${ }^{251}$

Muchos han cuestionado a Gramsci sus reservas respecto a la transformación de los regímenes y de los modelos de dominación a través del cambio revolucionario; pues la hegemonía no se identifica con la fuerza, sino con un proceso histórico que se logra mediante alianzas que permite a las sociedades avanzar. Así, Gramsci construye la categoría de bloque históri-

248 Ferrajoli, Luigi, Poderes salvajes. La crisis de la democracia constitucional, trad. de Perfecto Andrés Ibáñez, Madrid, Trotta, 2011.

249 Laclau, Ernesto y Mouffe, Chantal, Hegemonía y estrategia socialista. Hacia una radicalización de la democracia, Buenos Aires, Fondo de Cultura Económica, 2011.

250 Soria, Víctor, "Importancia de la teoría gramsciana del Estado para el estudio de la regulación económica y política del capitalismo actual”, en Martinelli, José María (comp.), La actualidad de Gramsci: poder, democracia y mundo moderno, op. cit., 1995, pp. 107-120.

251 Gramsci, Antonio, La política y el Estado moderno, Barcelona, Península, 1971. 
Este libro forma parte del acervo de la Biblioteca Jurídica Virtual del Instituto de Investigaciones Jurídicas de la UNAM

co para explicar el conjunto de fuerzas y relaciones que se conjugan para ejercer la dominación; se trata de crear una coalición política que sirva para promover las relaciones de clase, los vínculos entre las organizaciones sociales, con los partidos y el Estado, en donde es indispensable el trabajo de los intelectuales orgánicos - los de la burguesía y del proletariado-, además del desarrollo de una política cultural que apoye y cohesione esa alianza. ${ }^{252}$

Las teorías constitucionales también desdeñan el diseño democrático de las instituciones formales, por ejemplo, cómo organizar mejor, reformular o transformar a los poderes formales para que sirvan al propósito de la defensa y garantía de los derechos humanos. No sólo los tribunales constitucionales y los mecanismos de control de constitucionalidad y convencionalidad deben ser el objeto del análisis de las teorías constitucionales, sino también lo son el resto de las instituciones porque todas ellas posibilitan la realización de los derechos. Como ha demostrado Gargarella, existen instituciones en los sistemas constitucionales claramente contramayoritarias por su diseño - el ejecutivo unipersonal, los excesivos poderes del Senado y las Cortes Constitucionales - . En ese sentido, se podrían crear y diseñar nuevas instituciones que no tuviesen esos defectos para garantizar mejor los derechos humanos. Gargarella, que más bien proviene del constitucionalismo popular, propone las siguientes transformaciones institucionales:

a) Formas directas de democracia y reformulación de los sistemas representativos; b) fortalecimiento del poder legislativo en sus facultades de control al ejecutivo; c) rechazo al hiperpresidencialismo; d) reducción de los poderes del Senado para que se constituya exclusivamente como Cámara de defensa del Estado federal; e) quitar a la Corte Suprema la "última palabra" en las decisiones sobre la constitucionalidad de las leyes; f) inclusión de todos los sectores políticos y sociales en las instituciones y en otras esferas de la sociedad; g) introducción de acciones de inconstitucionalidad por omisión de las autoridades para garantizar derechos, principalmente los sociales, h) reconocimiento del interés difuso, etcétera. ${ }^{253}$

Por mi parte, considero que el entramado institucional que debe ser revisado para garantizar los derechos, comprende lo siguiente:

252 Paoli Bolio, Francisco José, Teoría del Estado, México, Editorial Trillas, 2009, p. 152.

253 Gargarella, Roberto, La sala de máquinas de la Constitución. Dos siglos de constitucionalismo en América Latina (1810-2010), Madrid, Katz, 2014. 
Este libro forma parte del acervo de la Biblioteca Jurídica Virtual del Instituto de Investigaciones Jurídicas de la UNAM

1) Los poderes fácticos nacionales y trasnacionales deben someterse a controles jurídicos suficientes que sean dirigidos o al menos supervisados por los ciudadanos.

2) Los derechos fundamentales deben contar con garantías plenas de realización, principalmente los derechos económicos, sociales, culturales y ambientales.

3) Es imperioso luchar por una democratización radical, al igual que por la transparencia, rendición de cuentas, eficiencia y eficacia de todas las instituciones del Estado.

4) Los tratados internacionales, principalmente los relacionados con el comercio, las inversiones y la propiedad deben ser votados por los ciudadanos para poder entrar en vigor en los respectivos ámbitos territoriales.

5) Los mecanismos de derecho procesal constitucional deben ser amplios y accesibles a cualquier ciudadano o grupo social para proteger con suficiencia los derechos fundamentales de carácter social y los derechos colectivos - la acción ciudadana de inconstitucionalidad sin tener que demostrar ningún tipo de interés legítimo-.

6) Los instrumentos anticorrupción deben dirigirse fundamentalmente en contra de las grandes corporaciones trasnacionales.

7) La democracia participativa, deliberativa y comunitaria necesita ser estimulada en todos los ámbitos.

8) El patrimonio de las naciones — sus recursos naturales- y su explotación deben corresponder exclusivamente a ellas a través de sus Estados.

9) La soberanía nacional debe seguir siendo un elemento importante para la definición del Estado y su actuar en el ámbito internacional.

10) Sobre todo, es imprescindible modificar el actual modelo económico neoliberal globalizador y sustituirlo por otro de naturaleza social que permita promover la industrialización interna y que fortalezca los mercados nacionales bajo criterios de igualdad ${ }^{254}$ para que se pueda realizar el Estado constitucional.

El análisis de la democracia en la teoría del Estado constitucional es muy débil e insuficiente. Algunos de sus autores, casi todos, se quedan en los márgenes la democracia liberal representativa; no se atreven a postular formas de democracia participativa y deliberativa radical o formas de democracia comunitaria.

${ }^{254}$ Cárdenas Gracia, Jaime, El modelo jurídico del neoliberalismo, México, UNAM, 2016. 
Este libro forma parte del acervo de la Biblioteca Jurídica Virtual del Instituto de Investigaciones Jurídicas de la UNAM

Las potencialidades de la democracia participativa han sido estudiadas, entre otros, por Leonardo Avritzer y Boaventura de Sousa Santos en el contexto brasileño. ${ }^{255}$ Para estos autores la democracia participativa implica darle poder permanente a los ciudadanos en las etapas interelectorales para que puedan participar en ellas para decidir cuestiones fundamentales del Estado - por ejemplo, aprobando mediante referéndum reformas constitucionales y leyes-, supervisando o vigilando autoridades permanentemente a través de auditorías ciudadanas, o proponiendo a éstas políticas públicas por medio de la iniciativa legislativa. Los autores citados explican que la Asamblea Constituyente en Brasil aumentó la influencia de distintos actores sociales en las instituciones políticas a través de nuevos arreglos participativos. El artículo 14 de la Constitución de 1988 de Brasil garantizó la iniciativa popular como iniciadora de procesos legislativos, el artículo 29 de esa ley fundamental requiere de la participación de los representantes de asociaciones populares en el proceso de organización de las ciudades, y otros artículos constitucionales, demandan la participación de las asociaciones civiles en la aplicación de las políticas de salud y asistencia social. Santos y Avritzer insisten en cómo el presupuesto participativo adquirió preeminencia en la vida municipal, y cómo la participación es parte de una herencia común del proceso democratizador que llevó a actores sociales democráticos, especialmente aquellos oriundos del movimiento comunitario, a disputarse el significado del término participación - en el caso de la ciudad de Porto Alegre esa disputa se articuló para lograr la apertura de espacios reales de participación de los ciudadanos en todas las decisiones- - El presupuesto participativo de Porto Alegre y de otras ciudades brasileñas surgió con esa intención, y según Boaventura de Sousa Santos, se manifiesta en tres de sus características principales: 1) participación abierta a todos los ciudadanos sin ningún status especial atribuido a cualquier organización, inclusive las comunitarias; 2) combinación de democracia directa y representativa, cuya dinámica institucional atribuye a los propios participantes la definición de las reglas de actuación, y 3) colocación de los recursos para inversiones basada en la combinación de criterios generales y técnicos, o sea, compatibilidad de las decisiones y reglas establecidas por los participantes con las

255 Sousa Santos, Boaventura de, "Presupuesto participativo en Puerto Alegre: para una democracia redistributiva", Democratizar la democracia. Los caminos de la democracia participativa, México, Fondo de Cultura Económica, 2004, pp. 391-486; Avritzer, Leonardo, "Modelos de deliberación democrática: un análisis del presupuesto participativo en Brasil", Democratizar la democracia. Los caminos de la democracia participativa, op. cit., pp. 487-518. 
Este libro forma parte del acervo de la Biblioteca Jurídica Virtual del Instituto de Investigaciones Jurídicas de la UNAM

exigencias técnicas y legales de la acción gubernamental y con respeto a los límites financieros. 256

Para Avritzer, ${ }^{257}$ las tres características anteriores se traducen en tres formas de institucionalidad participativa: 1) asambleas regionales en donde la participación es individual, abierta a todos los miembros de las comunidades y cuyas reglas de deliberación y decisión son definidas por los propios participantes; 2) un principio distributivo capaz de revertir las desigualdades en relación con la distribución de bienes públicos; en Porto Alegre y Belo Horizonte se llama "lista de carencias", y 3) un mecanismo de compatibilidad entre el proceso de participación y deliberación y el poder público, proceso que abarca, en el caso de Porto Alegre, el funcionamiento de un Consejo que delibera sobre el presupuesto y que negocia las prioridades con la autoridad local.

El presupuesto participativo de Porto Alegre, Belo Horizonte y de 140 ámbitos municipales en Brasil, combina la democracia representativa con la participativa en por lo menos tres niveles: los ciudadanos participan en un proceso de negociación y deliberación sobre prioridades en la distribución de bienes públicos; las listas de carencias y el Consejo del Presupuesto Participativo son ámbitos ciudadanos que amplían a nivel regional el debate público sobre las reglas de la participación, deliberación y distribución; finalmente, se negocian las prioridades presupuestales con la autoridad. Es importante señalar, que año con año, se incorporan más ciudadanos y ciudades en la gestión del presupuesto participativo. En la actualidad asumen este proceso 127 ciudades de más de 500,000 habitantes.

Las formas de participación ciudadana en Brasil, y en aquellos países del mundo que las reconocen, cuestionan sobre todo la exclusión social, y tienen como finalidad el combate a la pobreza mediante mecanismos en donde la ciudadanía determina las prioridades de las decisiones fundamentales o del gasto público. La participación ciudadana tiene muchas ventajas, entre otras, señalo: 1) involucra a los ciudadanos permanentemente y no sólo en las elecciones en los asuntos públicos, con lo que se legitima el

256 Existen, no obstante, críticas al presupuesto participativo. Recientemente, el sábado 29 de enero de 2005, el diario El País publicó un reportaje en donde se señala que sólo el 5\% de los habitantes de Porto Alegre toman parte en las asambleas ciudadanas que han hecho famosa a esa ciudad por haber originado el presupuesto participativo. Peregil, Francisco, "El mito del presupuesto participativo", El País, 29 de enero 2005, p. 12.

257 Avritzer, Leonardo, "Modelos de deliberación democrática: un análisis del presupuesto participativo en Brasil", Democratizar la democracia. Los caminos de la democracia participativa, op. cit., pp. 487 y ss. 
Este libro forma parte del acervo de la Biblioteca Jurídica Virtual del Instituto de Investigaciones Jurídicas de la UNAM

sistema político y las decisiones que se adoptan con y a partir de la sociedad; 2) permite, como en el caso de Brasil, redistribuir la riqueza mediante el señalamiento de las prioridades sociales en el gasto; 3) es un mecanismo que vuelve a unir a gobernados con gobernantes; 4) auxilia en el combate a la corrupción a través de mecanismos de control ciudadano; 5) puede conciliarse con la democracia representativa; 6) existen formas posibles de combinación entre democracia participativa y representativa, por ejemplo, dejar la democracia representativa en el nivel nacional o central y combinarla con elementos participativos en lo local y municipal, y otra, mucho más plausible, presupone el reconocimiento por el gobierno de que el procedimentalismo participativo, las formas públicas de monitoreo y los procesos de deliberación pública, pueden sustituir parte del proceso de representación y deliberación tradicional. ${ }^{258}$

Además de las formas anteriores de participación existen los mecanismos tradicionales de democracia semi-directa, como el referéndum, la iniciativa legislativa popular, la consulta ciudadana, la revocación de mandato, las acciones ciudadanas de inconstitucionalidad, entre otras, que proveen las válvulas de escape frente al descontento popular; posibilitan el control de los funcionarios corruptos, y lo más importante, permiten que las voces que no son normalmente tomadas en cuenta sean escuchadas. ${ }^{259}$ La democracia participativa tiene por propósito no excluir la participación ciudadana bajo ninguna forma y no privilegiar la participación de los ciudadanos sólo a través de los partidos. Sus mecanismos son deseables para limitar las consecuencias inaceptables de todo sistema representativo basado exclusivamente en los partidos: elitismo, restricción de movilidad de élites políticas y falta de transparencia en la deliberación y publicidad de los asuntos públicos.

El ejemplo suizo demuestra el papel que han desempeñado en ese país las distintas formas de referéndum, la revocación del mandato, y los procedimientos de iniciativa popular para la revisión de la Constitución y las leyes para la toma de otras decisiones. El objetivo de estas figuras es permitir la intervención del pueblo en las decisiones políticas clave y oponerse a sus élites. La experiencia de ese país demuestra que lejos de ser instrumentos nocivos al desarrollo social o económico, las figuras de democracia semi-

258 Cortina, Adela, "Ética del discurso y democracia participativa", Revista Sistema, núm. 112, enero de 1993, pp. 25-40.

259 Cronin, Thomas E., Direct Democracy: The Politics of Initiative, Referendum and Recall, Cambridge, Cambridge University Press, 1989, pp. 126 y 127, 225 y 226; Krause, Martín y Molteni, Margarita (cords.), Democracia directa, Buenos Aires, Abeledo-Perrot, 1997. 
Este libro forma parte del acervo de la Biblioteca Jurídica Virtual del Instituto de Investigaciones Jurídicas de la UNAM

directa han ampliado las libertades y reforzado la cohesión y la integración social en un Estado dividido por sus etnias y lenguas. ${ }^{260}$

En el debate actual sobre la calidad de la democracia se incluye a la participación ciudadana entre sus elementos, y se le vincula con la rendición de cuentas y desde luego con el Estado de derecho y la lucha contra la corrupción. Frances Hagopian dice, por ejemplo, que:

La calidad de una democracia no sólo implica protección de las libertades, de los derechos básicos, de la supremacía del Estado de derecho y de una igualdad básica, sino también de gobiernos que rindan cuentas (accountable) ante otros agentes del Estado y ante los ciudadanos, que sean responsivos (responsive) a las preferencias de éstos, que haya una competencia significativa por el poder y que los ciudadanos participen en la vida política. En otras palabras, que también se tenga en cuenta la participación, la competencia, la responsividad (responsiveness) y la rendición de cuentas (accountability) a simplemente conformarse con la representación política. ${ }^{261}$

Esta autora llega a decir de manera mesurada, que a largo plazo la competencia, la responsividad y la rendición de cuentas, estimulan más la participación y la lealtad a la democracia, que los buenos resultados gubernamentales. El problema del sistema representativo tradicional, como aquí se ha sostenido, es que aleja a los ciudadanos de la política y la elitiza. Para darle vigor nuevamente, se requieren entre otros elementos, el abrir los cauces a la participación ciudadana, ésta producirá ciudadanos de alta intensidad, preocupados por el sistema normativo, las decisiones públicas, y desde luego, la lucha contra la corrupción.

Dentro del debate sobre la calidad de la democracia, Leonardo Morlino señala que una democracia es de calidad cuando:

Primero. Presenta una estructura institucional estable que hace posible la libertad e igualdad de los ciudadanos mediante el funcionamiento legítimo y correcto de sus instituciones y mecanismos. Una buena democracia es, por tanto y ante todo, un régimen ampliamente legitimado, que satisface completamente a los ciudadanos, cuando las instituciones tienen el completo apoyo de la sociedad civil... Segundo, una buena democracia es aquella en la que los ciudadanos, asociaciones y comunidades que la componen disfrutan de li-

260 Ferriz Sánchez, Remedios y García Soriano, María Vicenta, Suiza. Sistema político y Constitución, Madrid, Centro de Estudios Políticos y Constitucionales, 2002, p. 93.

261 Hagopian, Frances, "Derechos, representación y la creciente calidad de la democracia en Brasil y Chile", Política y gobierno, México, vol. XII, núm. 1, primer semestre de 2005, p. 43 . 
Este libro forma parte del acervo de la Biblioteca Jurídica Virtual del Instituto de Investigaciones Jurídicas de la UNAM

bertad e igualdad. Tercero, en una buena democracia los propios ciudadanos tienen el poder de verificar y evaluar si el gobierno trabaja por los objetivos de libertad e igualdad de acuerdo al gobierno de la ley. Monitorean la eficiencia de la aplicación de las leyes vigentes, la eficacia de las decisiones tomadas por el gobierno, la responsabilidad y la rendición de cuentas políticas de los gobernantes electos en relación con las demandas expresadas por la sociedad civil. ${ }^{262}$

Las características de la calidad democrática tienen que ver con correcciones muy importantes a la democracia representativa porque ésta es insuficiente; una de las principales correcciones consiste en la amplia participación de los ciudadanos en los asuntos públicos.

Si no corregimos lo que se denomina en América Latina democracias delegativas, no tendremos democracias de calidad, aunque las democracias delegativas lleven a cabo elecciones relativamente limpias y los partidos, el parlamento y la prensa gocen de libertad y las cortes bloqueen políticas anticonstitucionales. Si en la práctica los ciudadanos no son tratados como personas, si delegan en otros las decisiones, si sólo participan en el momento en que votan y después no tienen oportunidad de verificar y evaluar la labor de sus gobernantes una vez electos, y si además, los órganos que deben realizar el control horizontal no funcionan debidamente, habrá una deslegitimación del sistema. ${ }^{263}$ Por ello debe ser potenciada la participación con mecanismos de democracia semidirecta y con fórmulas como las descritas por Boaventura de Sousa Santos o Avritzer, entre otros. Se debe asumir que los ciudadanos deben tener la oportunidad de evaluar la responsabilidad del gobierno en términos de la satisfacción de sus necesidades y requerimientos; solamente los ciudadanos son capaces de hacerlo, y saben más que los gobernantes acerca de sus necesidades. La participación, por tanto, es un correctivo a las deficiencias de la democracia representativa tradicional y un instrumento poderoso para enfrentar la corrupción.

En cuanto a la deliberación de los asuntos públicos, ésta es un elemento fundamental de una democracia avanzada. Como dice Joshua Cohen, la democracia deliberativa implica un marco de condiciones sociales e institucionales que facilita la discusión libre entre ciudadanos iguales y provee

262 Morlino, Leonardo, "Calidad de la democracia. Notas para su discusión”, Metapolítica, México, enero-febrero de 2005, pp. 38 y 39.

263 O’Donell, Guillermo, "Delegative Democracy", fournal of Democracy, vol. 5, núm. 1, 1994. 
Este libro forma parte del acervo de la Biblioteca Jurídica Virtual del Instituto de Investigaciones Jurídicas de la UNAM

condiciones favorables para la participación, asociación y la expresión. ${ }^{264} \mathrm{La}$ democracia deliberativa demanda que la autorización para ejercer el poder sea la consecuencia de una permanente discusión, mediante el establecimiento de un esquema de disposiciones que garantizan la responsabilidad y la rendición de cuentas ante los ciudadanos por parte de quienes ejercen el poder público; no sólo a través de las elecciones, aunque también de esa manera, sino con procedimientos amplios de publicidad de los asuntos públicos, supervisión al trabajo de las legislaturas y de otros poderes y órganos del Estado por parte de los ciudadanos.

En el esquema de democracia deliberativa se advierte que la democracia no se limita únicamente al proceso de agregación política por el voto y las elecciones, sino que implica un proceso público de argumentación, que disputa con el sistema político, las prerrogativas de la decisión política. ${ }^{265}$ A través de esa disputa se pretende ampliar la práctica democrática. ¿De dónde nace el esquema deliberativo? En su versión contemporánea de la obra de Habermas, elaboró el importantísimo concepto de esfera pública. ${ }^{266}$ Ese ámbito, llamado esfera pública, es un lugar para la libre interacción de grupos, asociaciones y movimientos sociales; dicha esfera supone la posibilidad de una relación crítico-argumentativa con la política. Para que funcione la democracia deliberativa se requieren varias condiciones o presupuestos, éstos son: a) los procesos de deliberación se realizan de forma argumentativa, o sea, a través del intercambio regulado de informaciones y razones entre pares que introducen y examinan críticamente propuestas; b) las deliberaciones son inclusivas y públicas, nadie en principio debe ser excluido, todos aquellos que posiblemente sean afectados por las decisiones tienen la misma oportunidad para entrar y tomar parte en ellas; $c$ ) las deliberaciones están libres de cualquier coerción externa, los participantes son soberanos en la medida en que se encuentran vinculados a los presupuestos de la comunicación y a las reglas procedimentales de la argumentación; d) las deliberaciones están libres de cualquier coerción interna capaz de afectar la igualdad de los participantes, cada uno de ellos tiene la misma oportunidad de ser oído, de introducir tópicos, de hacer contribuciones, de sugerir y criticar propuestas; e) las deliberaciones objetivan, en general, un acuerdo racionalmente motivado y pueden ser, en principio, desarrolladas sin res-

264 Cohen, Joshua, "Procedimiento y sustancia en la democracia deliberativa", Metapolítica, vol. 4, núm. 14, abril-junio de 2000, p. 29.

265 Avritzer, Leonardo, “Teoría democrática, esfera pública y deliberación”, Metapolítica, vol. 4, núm. 14, abril-junio de 2000, p. 86.

${ }^{266}$ Habermas, Jürgen, Facticidad y validez. Sobre el derecho y el Estado democrático de derecho en términos de teoría del discurso, Trotta, Madrid, 1998, pp. 363 y ss. 
Este libro forma parte del acervo de la Biblioteca Jurídica Virtual del Instituto de Investigaciones Jurídicas de la UNAM

tricciones o retomadas en cualquier momento; $f$ ) las deliberaciones políticas deben concluirse contrastando la decisión de la mayoría y ésta justifica el presupuesto de que la opinión falible de la mayoría puede ser considerada una base razonable para una práctica común hasta que la minoría convenza a la mayoría de lo contrario; $g$ ) las deliberaciones políticas abarcan todos los asuntos posibles de regulación, en particular aquellas cuestiones relevantes, teniendo en cuenta el interés igual de todos, $\mathrm{y} h$ ) las deliberaciones políticas se extienden también a la interpretación de necesidades y la transformación de preferencias y enfoques prepolíticos. ${ }^{267}$

Desde luego, la obra de Habermas junto con otros autores como Rawls o Nino, ha insistido en los elementos deliberativos. Rawls sostiene que la verdad moral se constituye por la satisfacción de presupuestos formales inherentes al razonamiento práctico de cualquier individuo, en particular el presupuesto de acuerdo al cual, un principio moral es válido si es aceptable para todas las personas que se encuentren bajo condiciones ideales de imparcialidad, racionalidad y conocimiento de los hechos relevantes. ${ }^{268}$

En el caso de Nino, la insistencia en la deliberación es más evidente. Nino dice que la verdad moral se constituye por la satisfacción de presupuestos formales o procesales de una práctica discursiva dirigida a lograr cooperación, evitar conflictos, y la discusión y la decisión intersubjetiva constituyen el procedimiento más confiable para tener acceso a la verdad moral. $\mathrm{El}$ intercambio de ideas y la necesidad de ofrecer justificaciones frente a los otros no sólo incrementa el conocimiento que uno posee, sino también, detecta defectos en el razonamiento y ayuda a satisfacer el requerimiento de atención imparcial a los intereses de todos los afectados; sin embargo, esto no excluye la posibilidad de que a través de la reflexión individual alguien pueda tener acceso al conocimiento de soluciones concretas, aunque debe admitirse que este método es mucho menos confiable que el colectivo, debido a la dificultad de permanecer fiel a la representación de los intereses de otros y ser imparcial. ${ }^{269}$

La democracia deliberativa es consciente que la regla de la mayoría no garantiza la imparcialidad. Una decisión apoyada por una mayoría y no por todos los involucrados en el conflicto puede ser muy parcial. La unanimidad tampoco es ideal, en buena medida por las necesidades reales de tomar una decisión en un tiempo limitado: la unanimidad como regla exclusiva condu-

267 Ibidem, pp. 382 y 383.

268 Rawls, John, La justicia como equidad. Una reformulación, Barcelona, España, Paidós, 2002.

269 Nino, Carlos Santiago, La constitución de la democracia deliberativa, Barcelona, Gedisa, 1997, pp. 154-198. 
Este libro forma parte del acervo de la Biblioteca Jurídica Virtual del Instituto de Investigaciones Jurídicas de la UNAM

ciría indefectiblemente a la defensa del status quo. Según Nino, como la regla de la mayoría y la regla de la unanimidad no son por sí mismas suficientes, debe recurrirse a otros elementos como:

1) El conocimiento de los intereses y necesidades de otros, lo que implica la inclusión de todos los sectores de la sociedad en la deliberación pública con el propósito de que los individuos tengan oportunidad de tomar decisiones que les ayuden a dar un orden de preferencias a sus intereses; 2) La necesidad de no presentar ante los demás exclusivamente desnudos intereses egoístas sino intereses, necesidades y, preferencias en un marco argumentativo de justificación permanente de cada punto de vista; 3) La discusión con otros contribuye a detectar errores fácticos y lógicos, pues no es común que la mayoría de la gente cometa el mismo error; 4) La exigencia de ponernos "en los zapatos de los demás" conociendo no sólo sus intereses sino sus emociones, lo que supone poseer la facultad intelectual de la imaginación y el atributo de la empatía; 5) El atributo del consenso - por encima de la mera negociación que se lleva a cabo sobre la base de puros intereses-, y 6) La tendencia colectiva hacia la imparcialidad derivada de la colegiación de las decisiones en un proceso de participación incluyente y de deliberación. ${ }^{270}$

El sistema representativo no responde a un esquema deliberativo, ${ }^{271}$ por eso Habermas propuso el modelo deliberativo mediante los presupuestos antes señalados y la definición de la política deliberativa a través de dos vías: primero, la formación de la voluntad democráticamente constituida en espacios institucionales, y segundo, la construcción de la opinión informal en espacios extra-institucionales. Según Habermas, a partir de la interrelación entre esos dos espacios es que se encuentra la posibilidad de un gobierno legítimo. ${ }^{272}$

La esfera pública captaría los impulsos generados en la vida cotidiana y los transmitiría a los colegiados competentes de carácter institucional para que se articulen formalmente. Avritzer dice que el papel de la esfera pública, no es producir deliberación, sino demandarla a las instituciones del Estado, y en ese sentido, la teoría habermasiana es mucho más una teoría de los modos informales de democratización de la democracia que de la institucionalización de formas ampliadas de ejercicio de la democracia. ${ }^{273}$ En otras

270 Ibidem, pp. 166-180.

271 Porras Nadales, Antonio, Representación y democracia avanzada, Cuadernos y Debates, Madrid, núm. 50, Centro de Estudios Políticos y Constitucionales, 1994.

272 Habermas, Jürgen, Facticidad y validez..., op.cit., pp. 407 y ss.

273 Avritzer, Leonardo, “Teoría democrática, esfera pública y deliberación”, op. cit., pp. 83 y 84 . 
Este libro forma parte del acervo de la Biblioteca Jurídica Virtual del Instituto de Investigaciones Jurídicas de la UNAM

palabras, Habermas no resuelve el problema de la conexión entre el mundo de la esfera pública informal y social con el sistema político formal; no propone soluciones claras para que el flujo de comunicación entre la esfera pública y el sistema político no se paralice o desconecte.

Ante la insuficiencia del planteamiento habermasiano, Cohen y James Bohman intentan dar una respuesta al problema de la desconexión entre la esfera pública y las instituciones. Cohen insiste en incardinar la esfera pública en el ámbito institucional; $; 74$ es decir, institucionalizar soluciones de problemas directamente por los ciudadanos y no simplemente promover la discusión informal con promesas de influencias posibles en la arena política formal. No obstante, Cohen no enfatiza con suficiencia que el lugar de la deliberación debe ser la propia esfera pública y que la democracia deliberativa debe pensar el proceso de construcción de instituciones para la deliberación pública, ${ }^{275}$ por ejemplo, los foros públicos deben ser el lugar de la democracia deliberativa y no las instituciones políticas, pues en opinión de Avritzer, la deliberación debe ocurrir al interior del propio espacio público.

Bohman pone el acento en el hecho de que la deliberación es más una actividad cooperativa y pública y menos una forma de discurso. ${ }^{276}$ Los objetivos del acto deliberativo son resolver las situaciones problemáticas (conflicto) y restaurar la cooperación entre los actores y coordinar sus resultados. Propone el control público a través de las diversas esferas públicas que deben formarse en torno a cada una de las instituciones; atribuye la legitimidad de una ley al resultado de un proceso participativo justo y abierto a todos los ciudadanos y que, como tal, incluye todas las razones públicamente accesibles de esas personas, lo que no presupone un acuerdo unánime entre ciudadanos o legisladores sobre todas las leyes, objetivos o decisiones, sino una cooperación continua a pesar de las diferencias de posición propias de una sociedad pluralista. La construcción del consenso, en esta versión, dependerá de la participación en el proceso político y legislativo, independientemente del desacuerdo en relación con cualquier decisión particular alcanzada deliberativamente. Lo que califica al procedimiento como deliberativo es su inclusividad. Acepta la institucionalización de la soberanía popular por medio de la regla de la mayoría y cualquier flaqueza que por casualidad llegara a presentar será corregida por instituciones contra-mayoritarias, como la re-

274 Cohen, Joshua, "Procedimiento y sustancia en la democracia deliberativa", op. cit., pp. 40-47.

275 Avritzer, Leonardo, “Teoría democrática, esfera pública y deliberación”, op.cit., p. 85.

276 Bohman, James, "La democracia deliberativa y sus críticos", Metapolítica, vol. 4, núm. 14, abril-junio de 2000, pp. 48-57. 
Este libro forma parte del acervo de la Biblioteca Jurídica Virtual del Instituto de Investigaciones Jurídicas de la UNAM

visión judicial. Bohman hace crítica a las instituciones públicas del Estado, y por eso, subraya que las instituciones públicas, burocráticas y administrativas, deben crear sus propias esferas públicas con el objetivo de llevar a cabo la deliberación. Sin la construcción de esas esferas públicas al interior de las instituciones, éstas no podrán controlarse y perderán la posibilidad de volverse más reflexivas y democráticas, gobernadas por la razón pública.

La crítica de Gohen y de Bohman a Habermas es justificable. Se trata de conectar la esfera pública con las instituciones, democratizar la esfera pública, pero también incorporar a la sociedad a las instituciones. El problema es que las instituciones burocráticas no permiten tal control público y están estructuradas de forma jerárquica, no democrática, y actúan frente a los ciudadanos de forma autoritaria como si fuesen clientes pasivos y no la fuente de la legitimidad, de la información y del juicio público. Los ciudadanos deben recuperar una actitud ofensiva frente a las instituciones.

En este sentido, como aquí se ha sostenido, la crisis está en el sistema representativo, el que debe ser corregido. Algunos proponen que la representación se conciba como una delegación para continuar la discusión a partir del punto alcanzado por los electores durante el debate que condujo a la elección de representantes en todas las sedes políticas de decisión: gobierno, parlamento y esfera judicial. En algunos casos es importante no delegar el mandato a los representantes, de modo que la gente pueda discutir por sí misma en forma directa lo que debe hacerse. Los partidos políticos pueden ayudar a materializar la visión deliberativa si funcionan de manera interna con democracia, si cuentan ellos mismos con procedimientos deliberativos, y si se encuentran organizados alrededor de posiciones ideológicas, sistemas de valores y modelos de sociedad, y no sobre la base de puros intereses de grupos económicos o sociales. El sistema representativo exige la inclusión del mayor número de sectores y de personas; así no está justificado, por ejemplo, hacer exclusiones basadas en la comisión de crímenes, pues la comisión de un delito no puede justificar la exclusión de la representación de los intereses del criminal del proceso político. Además, el sistema representativo debe ser modificado en las cuatro etapas clásicas del proceso: debate, mandato, control y actuación gubernamental, para incrementar sus componentes deliberativos y participativos. ${ }^{277}$

Carlos Nino considera que el elemento clave está en la implementación de la democracia deliberativa a través de cambios institucionales como:

277 Porras Nadales, Antonio, Representación y democracia avanzada, op. cit. 
Este libro forma parte del acervo de la Biblioteca Jurídica Virtual del Instituto de Investigaciones Jurídicas de la UNAM

...la inclusión de métodos de participación directa (plebiscito, referéndum, iniciativa popular, recall, etcétera); mecanismos capaces de revertir la apatía política como el voto obligatorio; modificar las reglas del debate público para que éste se centre en programas, plataformas electorales, y no en candidatos respaldados con apoyos mercadotécnicos; limitar el papel de la televisión en el debate público, pues ésta transforma casi todos los hechos y debates en espectáculos superficiales preparados para entretener, y esos espectáculos no intentan iluminar las controversias políticas y hacer reflexionar a la gente seriamente acerca de las consecuencias de las políticas en disputa, sino que buscan sorprender a los espectadores con el último escándalo, los medios, en fin, alimentan una espiral de demagogia e impactan negativamente sobre la racionalidad en el diseño de las políticas - son la respuesta a la falta de representación adecuada de la sociedad-; reformular los sistemas federales para descentralizar el poder, de tal suerte que los temas de crucial importancia sean discutidos y decididos a nivel provincial o incluso local y municipal, de lo que se trataría es de alentar la deliberación colectiva en unidades políticas pequeñas, llevadas a cabo por aquellos que se hallan directamente afectados por las cuestiones de mayor relevancia, adoptando mecanismos que aseguren la eficiencia y apertura, tales como la aprobación de leyes en las comisiones parlamentarias, convertir en públicas las reuniones de las comisiones y permitir la sanción de una ley con la aprobación de una de las cámaras, si la otra no toma intervención dentro de un determinado periodo de tiempo; democratizar la vida interna de los partidos; transformar el sistema electoral para fortalecer su proporcionalidad y así insiste en la conveniencia de un sistema mixto como el alemán y que la lista de representación no sea diseñada totalmente desde los partidos, que el orden lo fijen los ciudadanos; igualmente apuesta por un sistema parlamentario sobre el presidencial porque el primero es más inclusivo y no es de suma cero. ${ }^{278}$

Aunque su apuesta mayor está a favor de los sistemas semi-parlamentarios (Francia y Portugal), pues en éstos el presidente es el centro del poder mientras goza del suficiente apoyo popular, y cuando se debilita la popularidad del presidente tendrá que negociar con los legisladores; igualmente,

278 Según Juan Linz, el sistema parlamentario tiene frente al sistema presidencial las siguientes ventajas: la flexibilidad, existen soluciones constitucionales para la confrontación entre el Legislativo y el Ejecutivo, no se produce parálisis del Legislativo o los impasses entre los poderes, fortalece el sistema de partidos, favorece los juegos de suma positiva, se trata de un modelo diseñado para la cooperación y genera estabilidad política. Linz, Juan, "Presidential or Parliamentary Democracy: Does It make a Difference?", The Failure of Presidential Democracy. Comparative Perspectives, Baltimore y Londres, The Johns Hopkins University Press, vol. 1, 1994. 
Este libro forma parte del acervo de la Biblioteca Jurídica Virtual del Instituto de Investigaciones Jurídicas de la UNAM

se decanta por tribunales constitucionales más abiertos a la sociedad y en diálogo con el resto de los poderes. ${ }^{279}$

En otros trabajos hemos hecho propuestas en el sentido de $\mathrm{Nino}^{280} \mathrm{y}$ consideramos la necesidad de una democracia participativa y deliberativa diferente a la que existe en algunos países del mundo caracterizada por ser elitista. ${ }^{281}$ El modelo participativo-deliberativo destaca el control del representante por el representado y la deliberación pública y abierta de los asuntos en donde los ciudadanos pueden tomar parte en muchas decisiones de la autoridad. La deliberación implica la seria y atenta ponderación de razones a favor y en contra de alguna propuesta, es un proceso en virtud del cual un individuo sopesa razones a favor y en contra de determinados cursos de acción. ${ }^{282}$ La deliberación y participación producen una serie de virtudes en los ciudadanos y en el propio modelo. Se corrigen sesgos cognitivos, pues en ocasiones no basta con saber que existe un problema para calibrarlo; por ejemplo, en Estados Unidos un jurado compuesto por blancos no dispone de toda la información para entender la conducta de una madre hispana, dado que la sabiduría práctica no es sólo cuestión de disponer de buena información sino de sensibilidad para sopesarla. Se incrementa la producción de la virtud, pues cómo se puede reivindicar lo que se ignora, tal como ocurre con las mujeres de la India o de Afganistán que no demandan lo que no conocen.

El modelo deliberativo fomenta la participación ciudadana, acerca los políticos a los ciudadanos, les permite fiscalizarlos, conocer por qué tomaron unas decisiones y no otras, incluye a los ciudadanos en los procedimientos de toma de decisiones para poder determinar el nivel de justificación de cada punto de vista, y saber sobre la calidad normativa de cada decisión y cada paso en la construcción de decisiones públicas. Es obvio que incorpora a los ciudadanos en el terreno de lo público y los educa en las virtudes cívicas.

La Constitución en este modelo es un proceso abierto, una tarea que debe irse realizando, y coincide con el principio de que la democracia es

279 Nino, Carlos Santiago, La Constitución de la democracia deliberativa, op. cit., pp. 202-295.

280 Cárdenas Gracia, Jaime, Transición política y reforma constitucional en México, México, UNAM, 1994; mismo autor, Una Constitución para la democracia, México, UNAM, 1996; mismo autor, "El modelo participativo y deliberativo", Cuestiones Constitucionales. Revista Mexicana de Derecho Constitucional, México, núm. 11, 2004, pp. 55-89.

281 Ovejero, Félix, "Democracia liberal y democracias republicanas", Claves de Razón Práctica, Madrid, núm. 111, abril de 2001, pp. 18-30.

${ }^{282}$ Fearon, James D., "La deliberación como discusión”, en Elster, Jon, La democracia deliberativa, Barcelona, Gedisa, 2001, p. 88. 
Este libro forma parte del acervo de la Biblioteca Jurídica Virtual del Instituto de Investigaciones Jurídicas de la UNAM

un proceso que garantiza la configuración de múltiples alternativas a favor de los diversos grupos de la sociedad. Se valora a los procedimientos democráticos en la medida que aumenta la complejidad para hacer posible el surgimiento del mayor numero de alternativas políticas, sociales, culturales y económicas; se trata de la legislación del procedimiento democrático por la inclusión de muchos sectores sociales, por el activismo de los mismos, por el nivel de deliberación en la esfera pública y en la esfera institucional.

Es obvio, como dice Avritzer, que la deliberación debe ocurrir sobre todo al interior del propio espacio público; pero también deben existir los canales y las instituciones para que la esfera político-institucional se abra a la sociedad y a la deliberación que ésta propone en la esfera societal. Muchas propuestas existen para promover la deliberación en el ámbito institucional y social. Basta mencionar por el momento, entre otras, las siguientes: inclusión amplia de los mecanismos de democracia semi-directa, inclusión de prácticas participativas como el mecanismo de presupuesto participativo en todos los poderes y niveles de gobierno, la dinamización y activismo de los tribunales en la defensa a los derechos humanos, más y mejores mecanismos de rendición de cuentas, juridificación de la objeción de conciencia y aceptación política de la desobediencia civil, reconocimiento del derecho de resistencia frente a la opresión, democracia interna en los partidos, sindicatos y organizaciones empresariales, promoción de los movimientos sociales, la descentralización del poder, disciplinar en términos ecológicos al mercado y a las burocracias administrativas. ${ }^{283}$

Respecto a la democracia comunitaria, ésta entraña el reconocimiento de los derechos humanos individuales y colectivos de los pueblos originarios; ${ }^{284}$ fundamentalmente, se debe aceptar su autonomía, que es el medio existente para asegurarles el ejercicio con independencia de sus derechos políticos, sociales, económicos, jurídicos, culturales, territoriales y medioambientales. Los pueblos originarios tienen el derecho a la libre determinación; esto es, a definir libremente su condición política, jurídica y a establecer libremente su desarrollo económico, social y cultural. De ahí que tengan derecho a la consulta previa, libre e informada; como señala el artículo 6o. de la Convención 169 de la Organización Internacional del Trabajo (OIT) en todo lo que les afecte.

283 Pisarello, Gerardo, "Constitución y gobernabilidad: razones de una democracia de baja intensidad", Las sombras del sistema constitucional español, Madrid, Trotta, 2003, pp. 129149.

284 Díaz Polanco, Héctor, Elogio de la diversidad: globalización, multiculturalismo y etnofagia, México, Siglo XXI Editores, 2007. 
Este libro forma parte del acervo de la Biblioteca Jurídica Virtual del Instituto de Investigaciones Jurídicas de la UNAM

La democracia comunitaria implica instituir ámbitos territoriales con facultades de autogobierno en aquellas porciones territoriales en las que se encuentran asentados los pueblos originarios. La demarcación de estos territorios se debe basar en las características históricas, culturales, sociales e identitarias de los miembros de los pueblos originarios y en su voluntad expresada en asamblea o en consulta. En el caso mexicano se ha demandado el reconocimiento de los pueblos originarios como sujetos y entidades de derecho público, con personalidad jurídica y patrimonio propio; además, con formas autónomas de organización política y administrativa, sin que ello se lograra plenamente en la reforma constitucional de 2001 al artículo 2o. de la Carta Magna.

La democracia comunitaria significa, entonces, el autogobierno de los pueblos, la que debe fundarse en la expresión de la voluntad mayoritaria de su población a través de plebiscitos y consultas organizados según sus usos y costumbres. Los gobiernos, autoridades y representantes de los pueblos originarios son elegidos de acuerdo con sus propios sistemas normativos y procedimientos. En el caso de nuestro país, el gobierno de los pueblos originarios está conformado por:

1) La Asamblea Comunitaria. Es el órgano máximo de autoridad de los pueblos originarios en su respectivo ámbito territorial.

2) Las autoridades administrativas. Elegidas y encargadas de ejecutar las acciones emanadas de la Asamblea.

3) Las autoridades agrarias ejidales y comunales. Elegidas de acuerdo con las normas agrarias.

4) Las autoridades tradicionales. Elegidas por procedimientos internos para distintas actividades, tales como: mayordomías, comisiones de festejos, cofradías, patronatos, comisiones de panteón y otras determinadas por los propios pueblos.

Cuando existe democracia comunitaria se transfieren a los ámbitos territoriales de los pueblos indígenas competencias y facultades en materia política, administrativa, económica, social, cultural, educativa, judicial, y de manejo de los recursos y del medio ambiente; además de que son competentes para:

a) Elaborar su Estatuto a través de sus órganos de decisión, de forma participativa y de acuerdo con sus normas y procedimientos. 
Este libro forma parte del acervo de la Biblioteca Jurídica Virtual del Instituto de Investigaciones Jurídicas de la UNAM

b) Promover y reforzar sus propios sistemas, instituciones y formas de organización política, económica, social, jurídica y cultural; así como fortalecer y enriquecer sus propias identidades y prácticas culturales.

c) Organizar las consultas en torno a las medidas legislativas, administrativas o de cualquier otro tipo, susceptibles de afectación de los derechos de los pueblos originarios.

d) Decidir sus propias prioridades en lo que atañe al proceso de desarrollo y de controlar su propio desarrollo económico, social y cultural.

e) Participar en la formulación, aplicación y evaluación de los planes y programas de desarrollo de los diversos niveles de gobierno.

f) Adminitrar justicia en su jurisdicción a través de sus propias instituciones y sistemas normativos en la regulación y solución de los conflictos internos, respetando la interpretación intercultural de los derechos humanos y los principios generales de la Constitución.

g) Administrar sus bienes comunitarios: mercados, panteones, plazas, casas de cultura, museos, bibliotecas y otros.

h) Salvaguardar los espacios públicos y de convivencia comunitaria, así como la imagen urbana de sus pueblos, y vigilar y proteger sus edificios e instalaciones.

i) Adquirir, operar y administrar sus propios medios y sistemas de comunicación y difusión, así como radios comunitarias.

j) Establecer programas para preservar, controlar, reconstituir y desarrollar su patrimonio cultural (tangible e intangible), biológico, natural, artístico, lingüístico, saberes, conocimientos y sus expresiones culturales tradicionales, así como la propiedad intelectual colectiva de los mismos.

k) Participar activamente, en coordinación con las autoridades del Estado, en la elaboración y determinación de los programas especiales de salud, educación, vivienda y demás programas económicos y sociales que les conciernen, así como en la ejecución de esos programas mediante sus propias instituciones y/o vigilar colectivamente su cumplimiento.

l) Establecer programas para preservar y fortalecer sus propias medicinas tradicionales y prácticas de salud, incluida la conservación de sus plantas medicinales, animales y minerales de interés vital, así como promover los sistemas de salud comunitaria.

m) Participar colectivamente en el diseño, ejecución y evaluación de los programas económicos en sus ámbitos territoriales, así como partici- 
Este libro forma parte del acervo de la Biblioteca Jurídica Virtual del Instituto de Investigaciones Jurídicas de la UNAM

par, a través de sus autoridades o representantes, en la planificación de las políticas de desarrollo económico del resto de la sociedad.

n) Acceder al uso, gestión y protección de sus lugares religiosos, ceremoniales y culturales, encargándose de la seguridad y el respeto hacia los mismos.

o) Mantener, proteger y enriquecer las manifestaciones pasadas y presentes de sus culturas, como lugares arqueológicos e históricos, objetos, diseños, ceremonias, tecnologías, artes visuales e interpretativas y literaturas; utilizar y controlar sus objetos de culto; transmitir a las generaciones futuras sus historias, idiomas, tradiciones orales, filosofías, sistemas de escritura y literaturas. Asimismo, tienen derecho a la restitución, respecto de los bienes culturales, intelectuales, religiosos y espirituales, de que hayan sido privados sin su consentimiento libre, previo e informado o en violación de sus tradiciones y costumbres.

p) Establecer programas de investigación, rescate y aprendizaje de su lengua, cultura y artesanías.

La importancia de la democracia integral - representativa, participativa, deliberativa y comunitaria - como precondición del Estado constitucional es fundamental. Sin una activa participación de los ciudadanos y de los movimientos sociales, más allá de los momentos electorales, el Estado constitucional no es posible. ¿Por qué? Porque los ciudadanos y los movimientos sociales pueden supervisar, controlar, proponer y reclamar permanentemente a los gobernantes la satisfacción de los derechos. No se puede confiar exclusivamente en los mecanismos e instituciones de fiscalización del Estado, que en su mayor parte se encuentran cooptados por los poderes fácticos y formales. El ciudadano y los movimientos sociales tienen un papel importante para evitar el divorcio entre gobernante y gobernado, y exigir el cumplimiento de los derechos humanos. El Estado de partidos tradicional es un esquema periclitado, obsoleto, que se ha aliado al poder trasnacional para afectar la realización de los derechos.

Encuentro que las teorías del Estado constitucional requieren desarrollar una teoría de la democracia radical que vaya de la mano con la de los derechos humanos. Como dice un teórico norteamericano:

...para las mayorías pobres la solución de la crisis requiere de una redistribución radical de la riqueza y el poder, fundada en la construcción de estructuras democráticas más auténticas que permitan el control popular sobre las instituciones locales y trasnacionales. Las posibilidades de transformación 
Este libro forma parte del acervo de la Biblioteca Jurídica Virtual del Instituto de Investigaciones Jurídicas de la UNAM

que se han abierto en América Latina no se pueden realizar sin un programa socialista democrático y una izquierda organizada. ${ }^{285}$

Uno de los problemas para la radicalización de la democracia en el mundo, es que existen muchos grupos y particularismos - ecologistas, feministas, indigenistas, multiculturalistas, etcétera- y cada quién defiende su agenda intensamente, sin una concepción universal que comprenda a todos esos grupos. Ésta se puede encontrar en el paraguas de los derechos. El radicalismo del particularismo debe llevar al radicalismo también de los valores universales: justicia, igualdad y libertad. Para ello se requiere que los movimientos sociales de diverso género interactúen, se alíen y compartan agendas. La finalidad es luchar contra los esquemas de dominación que hacen inviable el logro de los derechos y del Estado constitucional como lo conciben los juristas. ${ }^{286}$

Además, se trata no sólo de la radicalización de la democracia política, sino de la social y económica. La democratización tiene que alcanzar los ámbitos familiares, empresariales y económicos, pues mientras los hijos sean cosas o propiedad de los padres, un trabajador sea un costo o una herramienta para los propietarios del dinero y de los medios de producción, será muy deficitaria la legitimidad del Estado constitucional. Lo importante es saber que el Estado y el derecho pueden aproximarse a la realización de ciertos derechos humanos, pero no pueden hacer milagros, si los individuos y la sociedad no luchan por más altos niveles de igualdad y de libertad. ${ }^{287} \mathrm{La}$ democracia política sino viene acompañada por la democracia económica y social, aunque sea muy radical, no es capaz de llevar a cabo la emancipación humana. ${ }^{288}$

En la propuesta contrahegemónica que debieran elaborar las teorías del Estado constitucional, sería muy importante que se supiera por lo qué se está luchando, qué clase de sociedad nacional y mundial es la qué se quiere establecer. Es fundamental tener una comprensión de las relaciones de poder nacionales y trasnacionales vigentes para entender la dinámica de la política

285 Robinson, William I., América Latina y el capitalismo global. Una perspectiva crítica de la globalización, México, Siglo XXI Editores, 2015, p. 355.

286 Harvey, David, Espacios de esperanza, Madrid, Akal, 2012, pp. 276 y 277.

287 López Calera, Nicolás María, Yo, el Estado, Madrid, Trotta, 1992, p. 114.

288 Espósito, Roberto, Diez pensamientos acerca de la política, México, Fondo de Cultura Económica, 2012, p. 70. 
Este libro forma parte del acervo de la Biblioteca Jurídica Virtual del Instituto de Investigaciones Jurídicas de la UNAM

y el papel del derecho en esos esfuerzos alternativos. ${ }^{289} \mathrm{Y}$ esa tarea, las teorías del Estado constitucional ni siquiera la han empezado.

El multiculturalismo y el comunitarismo tienen igualmente un papel secundario dentro del análisis de las teorías del Estado constitucional porque la visión de los derechos humanos no se entiende desde las luchas de las sociedades, comunidades e identidades. La concepción de los derechos en los ordenamientos jurídicos, como dice Costas Douzinas:

...se moviliza en nombre de una cultura global, de los valores y principios que son un intento de cerrar las sociedades y de imponerles una lógica única. Que esa lógica sea occidental o cualquier otra, es secundaria; el punto es que se sigue un principio de unidad en contra de las ideas de indeterminación social y de autocreación existencial prometidas por la historia radical del derecho natural. Pero los derechos humanos también son un poderoso imaginario abierto a diversas identidades, a tradiciones heterogéneas y suprimidas. Los derechos humanos como un principio de política popular expresan la indeterminación y apertura de las sociedades a la política. Los derechos socavan el intento de reprimir algunas identidades sociales y de sancionar otras, y su indeterminación significa que los límites de la sociedad siempre son disputados y nunca coinciden completamente con las cristalizaciones que imponen el poder y los títulos legales. Los derechos humanos encierran a la vez un principio de unidad y de homogeneidad y su opuesto, el primero simbolizado por la forma legal y el último por las luchas de la gente. ${ }^{290}$

Para entender los derechos humanos desde el comunitarismo y multiculturalismo debemos entender al otro, al diferente, al que pertenece a culturas distintas a las occidentales, y que reclama, en sus luchas de resistencia, uno o varios proyectos de derechos humanos diversos a los nuestros. La concepción de los derechos humanos no es occidental, ni se encuentra sólo en las cosmovisiones europeas y anglosajonas. En donde hay individuos y grupos que en ejercicio de sus autonomías pretenden resistirse al poder, el que sea, y lo hacen desde la defensa de su dignidad y de sus valores societales y culturales, están reclamando la vigencia de derechos humanos que no necesariamente son los nuestros.

Desgraciadamente, la posición dominante en las teorías del Estado constitucional, poco repara en el carácter histórico, político, contingente, cultural y comunitario de los derechos humanos. Al centrarse fundamental-

${ }^{289}$ Laclau, Ernesto y Mouffe, Chantal, Hegemonía y estrategia socialista. Hacia una radicalización de la democracia, Buenos Aires, Fondo de Cultura Económica, 2011, p. 20.

290 Douzinas, Costas, El fin de los derechos humanos, Antioquia Colombia, Legis Editores, 2008, p. 456. 
Este libro forma parte del acervo de la Biblioteca Jurídica Virtual del Instituto de Investigaciones Jurídicas de la UNAM

mente en el individuo y en su pertenencia a la cultura occidental, se desdeña que otras manifestaciones culturales y/o plurinacionales puedan considerarse concreciones de los derechos humanos. Como dice Luis Villoro:

...la persona no es un individuo sin atributos, incluye la conciencia de su propia identidad como miembro de una colectividad y ésta no puede darse más que en un contexto cultural... Las creencias básicas que determinan las razones válidas, los fines elegibles y los valores realizables, varían de una cultura a otra. Por tanto, el respeto a la autonomía de las personas incluye el de las comunidades culturales a las que pertenecen. El "derecho de los pueblos" sólo puede contarse entre los derechos humanos fundamentales, en la medida en que el "pueblo" sea una condición para la autonomía de la persona. ${ }^{291}$

En ese sentido es muy discutible sostener, como lo hace nuestra Constitución y algunos teóricos, que no son derechos humanos aquéllos derechos colectivos que violentan derechos individuales de sus miembros. ${ }^{292}$ Los derechos humanos lo son, independientemente de su origen individual o colectivo, si existen buenas razones para que lo sean y si son instrumento de resistencia frente a la opresión de los otros, sobre todo cuando ésta tiene su origen directo en la explotación económica, política o social. Se trata de cuestiones abiertas que no pueden cerrarse de una vez y para siempre, son producto de una deliberación colectiva, plurinacional y multicultural. Como también dice Douzinas, el fin de los derechos humanos es la promesa de lo que todavía no es, pero que se pretende que sea, para que una vez realizado se pueda volver a poner en cuestión. ${ }^{293}$

Los liberales a ultranza suelen insistir en la superioridad de los derechos humanos en occidente sobre oriente o respecto a otras latitudes, porque los derechos se apoyan en la autonomía y dignidad humanas. Sin embargo, ese punto de vista no asume que, por ejemplo, los comunitaristas consideran que el individuo sólo se realiza en su pertenencia con la comunidad, por lo que sostener a ultranza los valores de autonomía y dignidad en contra de culturas, credos o tradiciones, equivale a reconocer que no hay respeto a las diferencias ${ }^{294}$, y esas diferencias culturales, como también sus fundamentos,

291 Villoro, Luis, "Sobre derechos humanos y derechos de los pueblos", Revista Isonomía, México, núm. 3, octubre de 1995, p. 10.

292 Vázquez, Rodolfo, Derechos humanos. Una lectura liberal igualitaria, México, UNAMITAM-Centro de Estudios de Actualización en Derecho, 2015, pp. 167-171.

293 Douzinas, Costas, El fin de los derechos humanos, op. cit., p. 462.

294 Prieto Sanchíz, Luis, El constitucionalismo de los derechos, op. cit., p. 244 y 245. 
Este libro forma parte del acervo de la Biblioteca Jurídica Virtual del Instituto de Investigaciones Jurídicas de la UNAM

merecen respeto y consideración. No pueden ser descartadas sin más, sin que exista un diálogo o deliberación entre culturas.

La manera de entender la globalización es otra de las debilidades del Estado constitucional. Ferrajoli propone globalizar el constitucionalismo, aunque asume que es una tarea de difícil realización. ${ }^{295}$ Manuel Atienza en polémica con Ferrajoli, en torno a la existencia de una moral objetiva, como fundamento de los derechos, señala que sí debe mundializarse el constitucionalismo y propone el derecho humano universal a recibir una renta básica, la que se financiaría con la famosa tasa Tobin que gravaría las especulaciones financieras internacionales. ${ }^{296}$ Otros, como Laporta, sostienen que la globalización neoliberal no afecta las estructuras jurídicas nacionales. ${ }^{297}$ En fin, salvo el punto de vista más elaborado de Ferrajoli, existen pocas referencias en las teorías del Estado constitucional sobre lo que implica la globalización para esa forma de Estado, que se supone vigente y que entraña el mayor riesgo para toda su construcción epistémica y materialización.

Dice Boaventura de Sousa Santos, que el nuevo derecho de la globalización jurídica no es producto del impulso intelectual de juristas bien intencionados, sino de los poderes de dominación mundial y de abogados, burócratas estatales, instituciones internacionales, trasnacionales, algunos movimientos populares y organismos no gubernamentales que proponen un nuevo derecho para las nuevas realidades. El proceso de construcción del nuevo derecho no es monolítico sino muy diverso, aunque en él han ido ganando los intereses de las grandes corporaciones mundiales y de las potencias más importantes sobre las organizaciones no gubernamentales que defienden los derechos humanos, el ius humanitatis o el medio ambiente. ${ }^{298}$

Es muy difícil explicar, describir y teorizar el desarrollo de este nuevo derecho por su carácter complejo y heterogéneo. Conviven en su construcción múltiples expectativas, reclamos e intereses. Por una lado, están las demandas de inclusión, igualdad o reclamos de identidad de los pueblos, individuos y grupos sociales, y por el otro, están la desigualdad creciente en

295 Ferrajoli, Luigi, "La crisis de la democracia en la era de la globalización", Law and fustice in a Global Society, Granada, Anales de la Cátedra Francisco Suárez, 2005, pp. 50 y 51.

296 Atienza, Manuel, "Constitucionalismo, globalización y derecho", en Carbonell, Miguel y García Jaramillo, Leonardo, (coords.), El canon neoconstitucional, op. cit., pp. 264-281.

297 Laporta, Francisco, "Globalización e imperio de la ley. Un texto provisional para el debate con algunas dudas y perplejidades de un viejo westfaliano", Law and Fustice in a Global Society, op. cit., pp. 235 y 236.

298 Sousa Santos, Boaventura de, Sociología jurídica crítica. Para un nuevo sentido común en el derecho, Madrid, Trotta, Madrid, 2009, pp. 292 y ss. 
Este libro forma parte del acervo de la Biblioteca Jurídica Virtual del Instituto de Investigaciones Jurídicas de la UNAM

el mundo, la explosión demográfica, la catástrofe ambiental, la proliferación de armas de destrucción masiva, los intereses de las grandes corporaciones internacionales y los intereses geopolíticos de las principales potencias.

La globalización neoliberal puede - desde una visión de poder, con la complicidad de los intereses geopolíticos - explicarse la existencia de una triple alianza entre las empresas trasnacionales, el capital local y la burguesía estatal. ${ }^{299}$ Los tres factores o elementos de esta alianza comparten su situación común de privilegio sociopolítico y su interés por incrementar su influencia, no sólo en los ámbitos económicos, sino en los sociales y políticos de todas las naciones y en los procesos de integración mundial y regional. Para ello, se auxilian de la política y del derecho a fin de lograr sus objetivos.

Aunque aún desconocemos las consecuencias definitivas de la globalización neoliberal para el Estado y el derecho - si desaparecerá el Estadonación o se adaptará a las nuevas circunstancias - los teóricos que han buscado entender los fenómenos vinculados a ella destacan distintas maneras jurídicas de analizarla, y éstas son: la trasnacionalización de la regulación del Estado-nación; el derecho de la integración regional; el resurgimiento de la lex mercatoria; el derecho de las personas que atraviesan fronteras; el derecho de los pueblos indígenas; el cosmopolitismo subalterno e insurgente y los derechos humanos, y derecho de los recursos naturales globales de propiedad común. ${ }^{300}$ A estas variables debemos sumar de manera destacada la crisis del principio de soberanía; el desmantelamiento del Estado del bienestar; la opacidad e ilegitimidad con la que se crea y aplica el derecho de la globalización neoliberal; y, el despojo de los recursos naturales por parte de los Estados hegemónicos a los Estados débiles o periféricos.

Sobre la crisis de la soberanía, podemos decir que el modelo de Estado westfaliano, que creó el Estado-nación caracterizado por la centralización del poder en un gobierno que controla un territorio, la expansión del gobierno administrativo, la legitimación del poder a través de la teoría representativa, y el monopolio de la fuerza concentrado en las fuerzas armadas y cuerpos de seguridad pública, ha sido sustituido por una nueva forma de Estado que se podría denominar trasnacional. La característica principal de este nuevo Estado es que las principales decisiones que afectan a las sociedades nacionales no se adoptan por los representantes electos de cada nación, sino en sedes extra nacionales. Esas decisiones tienen que ver, prin-

299 Evans, Peter, Dependent Development: the Alliance of Multinational, State and Local Capital in Brazil, Princeton, PUP, 1979.

300 Sousa Santos, Boaventura de, Sociología jurídica crítica. Para un nuevo sentido común en el derecho, op. cit., pp. 329 y ss. 
Este libro forma parte del acervo de la Biblioteca Jurídica Virtual del Instituto de Investigaciones Jurídicas de la UNAM

cipalmente, con las condiciones de vida de las sociedades y son tomadas por actores, instituciones y agentes no nacionales. Las resoluciones que se implementan en cada nación tienen como objetivo garantizar los procesos de acumulación del capitalismo mundial, favorecer a los grandes intereses económicos trasnacionales y nacionales, y en su caso, responder a lógicas geopolíticas que benefician a las grandes potencias mundiales, las que, por otra parte, están al servicio de los intereses económicos mundiales. De esta suerte, el poder ya no está centralizado en el Estado, sino que se encuentra deslocalizado en instituciones y agentes económicos supranacionales, el gobierno administrativo de cada Estado se reduce, flexibiliza y se ajusta a las necesidades del capitalismo mundial, los poderes extra nacionales no están legitimados democráticamente, y el poder militar fundamental se localiza en las grandes potencias mundiales o en instituciones supranacionales controladas por esas potencias.

Estudiosos, como David Held, sostienen que la operación de los Estados-nación en este sistema mundializado o globalizado limita su autonomía y las posibilidades de la soberanía estatal como se entendió en el pasado. ${ }^{301}$ ¿Por qué? Porque las decisiones nacionales más importantes no se adoptan por las sociedades locales sino en instancias externas; porque la regulación jurídica nacional se debe adecuar a las necesidades del capitalismo mundial; porque la regulación trasnacional se considera jerárquicamente superior a la nacional, y por tanto, esa regulación no puede ser transgredida sin graves consecuencias para el Estado-nación, y porque las redes de regulación jurídica mundial complejizan y obstaculizan el funcionamiento de las autoridades locales que aparecen desconcertadas ante las realidades del nuevo derecho trasnacional.

En cuanto a la pervivencia de cualquier forma de bienestar - garantía de los derechos económicos, sociales, culturales y ambientales, tal como postulan las teorías del Estado constitucional-, como dice José Eduardo Faria, cuanto más veloz es la integración de los mercados en un sistema mundo o en una economía-mundo, más se reduce la capacidad de coordinación macroeconómica de los Estados-nación, pues mediante las recomendaciones de los organismos financieros internacionales llega a impedírseles establecer políticas keynesianas de altas tasas de gasto público para sustentar el empleo o el crecimiento económico. ${ }^{302}$ De esta manera, las posibilidades del Estado se reducen para garantizar o contribuir a garantizar los derechos de igual-

301 Held, David, y McGrew, Anthony, Globalización-antiglobalización. Sobre la reconstrucción del orden mundial, Barcelona, Paidós, 2003.

302 Faria, José Eduardo, El derecho en la economía globalizada, Madrid, Trotta, 2001, p. 30. 
Este libro forma parte del acervo de la Biblioteca Jurídica Virtual del Instituto de Investigaciones Jurídicas de la UNAM

dad. El modelo jurídico neoliberal de la globalización se caracteriza por la reducción sustancial en la satisfacción de los derechos económicos, sociales, culturales y ambientales. En este modelo, los ciudadanos del Estado nación tienen menos acceso al empleo, a la salud, a la educación, a la vivienda y a otros derechos sociales de igualdad.

La globalización neoliberal impulsa una nueva regulación del Estadonación, la que implica que el Estado-nación realiza ajustes al derecho interno para que éste sea compatible con las exigencias de la globalización neoliberal. ${ }^{303}$ Los ajustes principalmente ocurren en el derecho económico, comercial y social, aunque se pueden extender a otros ámbitos, como el del derecho electoral, a fin de configurar democracias formales, no siempre auténticas, que no fortalecen la construcción de ciudadanía. Las finalidades de esos ajustes jurídicos son la liberalización del comercio, la privatización de industrias o sectores, la liberalización agrícola, el desmantelamiento de las agencias reguladoras, la flexibilización del mercado laboral, la privatización de los servicios sociales vinculados a la salud o a la educación, la menor preocupación por los asuntos ambientales, entre otros.

La globalización de la regulación del Estado-nación no tiene los mismos efectos sociales en los países desarrollados que en los subdesarrollados. En éstos, las consecuencias pueden ser, en mayor medida que en los Estados más poderosos, el incremento de la desigualdad y el apuntalamiento de la influencia y del poder en las élites locales y mundiales sobre las poblaciones locales. Las nuevas regulaciones de la globalización pueden traer consigo fenómenos de inseguridad e ingobernabilidad porque a la pobreza crónica de las sociedades nacionales se suma la eliminación de todo tipo de protección social o de otra índole a cargo del Estado.

El derecho a la integración regional que entraña la globalización neoliberal significa que los Estados-nación crean instituciones y competencias jurídicas supranacionales. Las nuevas entidades asumen competencias que antes tenían los Estados. Los procesos de integración no suelen ser votados, se realizan sin la participación de las sociedades locales, y por ello, existe un serio déficit de legitimidad democrática. Casi siempre los responsables de las entidades supranacionales no son electos democráticamente y el procesamiento de sus decisiones no se acostumbra a ventilar públicamente. La ilegitimidad democrática y la opacidad son las características distintivas de los procesos de integración. ${ }^{304}$

303 Idem.

304 Hernández Cervantes, Aleida, La producción jurídica de la globalización económica, México, UNAM-Universidad Autónoma de San Luis Potosí-Centro de Estudios Jurídicos y Sociales 
Este libro forma parte del acervo de la Biblioteca Jurídica Virtual del Instituto de Investigaciones Jurídicas de la UNAM

Las entidades supranacionales se construyen y desarrollan generalmente para promover dos objetivos: 1) la integración económica y comercial, y 2) la protección de los derechos humanos. De esos dos objetivos prevalece el económico y el comercial, que es el que recibe el mayor impulso. La integración para la salvaguarda de los derechos humanos se utiliza como instrumento de legitimación del primer objetivo y va a la saga de él, porque si sustituyera a la preponderancia con la que cuentan los procesos de integración económica y comercial, se podría afectar seriamente al proyecto de la globalización. Así, en las entidades supranacionales de los derechos humanos, la garantía de los derechos económicos sociales, culturales y ambientales, recibe menor respaldo que la salvaguarda de los derechos de la llamada primera generación.

Todo lo anterior obliga a las sociedades nacionales y mundiales a profundizar el discurso y la práctica de la democracia radical - participativa, deliberativa, comunitaria, además de representativa - y de las estructuras e instituciones tradicionales del Estado constitucional, a la par que debemos construir y realizar una teoría económica y social que sea capaz de justificar, costear y respaldar las propuestas y proyectos constitucionales y de derechos que las sociedades hagan desde las esferas jurídicas y políticas locales e internacionales. El Estado constitucional, tal como hoy se manifiesta, sin una transformación en el modelo capitalista de dominación, y sin un rediseño nacional y mundial de las instituciones vigentes de carácter representativo, será incapaz de satisfacer en un sentido fuerte a los derechos humanos que se pretende salvaguardar y proteger, y que teóricamente, le dan razón a su existencia.

Aparejado a lo anterior, una gran deficiencia de las teorías del Estado constitucional es su concepto de democracia constitucional. Mis razones de crítica son las siguientes:

1) Si democracia son también los derechos humanos y no sólo la regla de la mayoría, hay que admitir en cuanto a exigibilidad, que existen algunos derechos: los económicos, sociales, culturales y ambientales, que se protegen de manera inferior a los derechos de libertad - no todos los derechos se protegen y garantizan igual-.

2) Las teorías del Estado constitucional presentan a los derechos humanos como universales, absolutos e inalienables, es decir, como derechos previos al orden jurídico, de fuerza superior a la jurídica - de carácter moral objetivo - y como derechos a los que se puede re-

Mispat, 2014, pp. 203-216. 
Este libro forma parte del acervo de la Biblioteca Jurídica Virtual del Instituto de Investigaciones Jurídicas de la UNAM

nunciar pero no abandonar; sin embargo, el alcance y significado de los derechos depende de las concepciones filosóficas y culturales que están detrás de ellos, como lo demuestran, por ejemplo, el análisis de las corrientes filosóficas, el comunitarismo y el multiculturalismo.

3) Los derechos humanos surgen de las aspiraciones de grupos en resistencia frente al poder, ¿cuándo hablamos de derechos, de cuáles estamos hablando? De los establecidos en Constituciones y tratados creados por burocracias nacionales y/o supranacionales no electas y opacas, o de los derechos que están por nacer de las luchas políticas y sociales frente y en contra del poder establecido.

4) La tesis del fundamento moral objetivo y absoluto de los derechos es equivocada porque no toma en cuenta las circunstancias históricas, sociales y económicas del devenir humano, ni tampoco se hace cargo de que los derechos que merecen ser sustantivados, son los que resultan de procedimientos deliberativos, participativos y democráticos, que se debieran ventilar en el seno de las sociedades, al interior de las culturas y entre culturas.

5) Finalmente, cómo decir cuáles y qué derechos, cuando son élites de expertos quienes los definen actualmente, prescindiendo de las sociedades. Existe en su concepción, significación y alcances actuales, una tendencia a la oligarquización de los derechos y una violación a los principios de autonomía y dignidad, pues se dice por las corrientes liberales, que son los dos valores que dan sustento y justificación de los derechos. ¿Acaso las sociedades, culturas e individuos que las componen no deben ser tomados en cuenta y de manera directa para la determinación de cuáles derechos deben reconocerse como tales, y no a través de representantes y expertos, que no tienen vínculos efectivos con ellas?

La democracia constitucional es un arreglo para garantizar los derechos fundamentales de los ciudadanos en un sentido muy fuerte, ${ }^{305}$ pero muy equivocado porque carece de sustento histórico, social y económico, así como de una base deliberativa y participativa. Se sostiene, lo que no dudo, que las mayorías pueden violar los derechos humanos de las minorías o de una persona, y por eso, no pueden ser equivalentes a la democracia, pero son principalmente las minorías del mundo neoliberal, las que infringen los derechos. La democracia constitucional también nos previene en contra del concepto de soberanía como equivalente a mayorías, ésta, se dice, no es asimilable ni

305 Ferrajoli, Luigi, Derechos y garantías: La ley del más débil, Madrid, Trotta, 2010, p. 25. 
Este libro forma parte del acervo de la Biblioteca Jurídica Virtual del Instituto de Investigaciones Jurídicas de la UNAM

a las mayorías ni a las unanimidades, tanto las mayorías como las unanimidades o las mismas minorías son fragmentos de la soberanía. La soberanía termina o concluye cuando se postula, es una idea regulativa, que propone una noción de salvaguarda de los derechos de todos. La democracia constitucional constituye una limitación al poder de las mayorías, y supone falsamente, que lo hace a nombre de las minorías desvalidas y excluidas, cuando son éstas las que suelen violar los derechos de las mayorías. ${ }^{306}$

Las minorías a las que se dice proteger por medio de los derechos, no son sociológicamente las más débiles, son las más poderosas de las naciones y del planeta, como lo demuestran las teorías críticas con el neoliberalismo globalizador. Esas minorías poderosísimas cuentan con los derechos para oponerlos a las amplísimas mayorías que habitan las naciones y el planeta; además, tiene de su lado la estructura institucional de protección, pues los guardianes de los derechos son burócratas no electos, que muchas veces dependen de esos grandes y minoritarios intereses, y definen en total opacidad lo qué son y no son los derechos.

Esto significa que un rasgo muy reprochable de las teorías constitucionales reside en los garantes de los derechos, en las instituciones nacionales y supranacionales que los definen y determinan. Los derechos se reconocen en la opacidad e ilegitimidad; la opacidad es evidente porque los derechos son reconocidos por instancias supranacionales y nacionales sin el concurso de las sociedades, sin rendición de cuentas. Los procedimientos de generación de los derechos se toman por unos cuantos funcionarios - la tecnocracia nacional y supranacional de los derechos humanos- y las sociedades nacionales desconocen con suficiencia las razones, motivos o argumentos que esgrimen esas personas para reconocer los derechos, a quién se beneficia y por qué no beneficia o se reconocen derechos bajo criterios alternativos. El proceso de reconocimiento de derechos - como prueba la reforma mexicana de derechos humanos del 10 de junio de 2011- se realiza sin suficiente luz y taquígrafos, sin debates parlamentarios y sociales amplios, y sin que los sectores sociales involucrados por los derechos puedan exponer extensamente sus puntos de vista en esos procedimientos y reconocimientos. Es ilegítimo el reconocimiento de los derechos porque muchas veces en su definición, ésta se efectúa por personas que no han sido electas por el pueblo, que no le rinden cuentas al pueblo, que no pueden ser removidas de sus funciones por el pueblo y porque el derecho reconocido no responde, en variadas ocasiones, a los intereses y necesidades del pueblo, sino a los derechos

306 Salazar Ugarte, Pedro, La democracia constitucional: una radiografia teórica, Madrid, Fondo de Cultura Económica de España, 2007. 
Este libro forma parte del acervo de la Biblioteca Jurídica Virtual del Instituto de Investigaciones Jurídicas de la UNAM

fundamentales de las minorías - las grandes corporaciones internacionales y de los poderes políticos y económicos que están detrás de ellas- - Los derechos humanos reconocidos no se aprueban en muchos países mediante el referéndum ciudadano. Además son derechos que no pueden ser derogados o abrogados por los ciudadanos de los Estados-nación.

Los tribunales o cortes constitucionales, garantes de las teorías del Estado constitucional, merecen abundantes críticas. Existe en el mundo entero una fuerte discusión académica pero también política sobre el problema de la legitimidad democrática de los jueces constitucionales. Preguntas como: ¿por qué el poder judicial, que no es producto de una elección popular, puede invalidar una ley emanada del legislativo?, ¿cómo la decisión democrática puede ser interferida por quienes no representan a nadie?, ¿en nombre de qué las generaciones pasadas pueden atar a las generaciones futuras?, ¿por qué parece que en el Estado constitucional democrático de derecho el poder se traslada del legislador al juez? Todas estas preguntas y otras similares, así como sus difíciles respuestas, tienen que ver con la legitimidad democrática de los jueces, pero sobre todo, con los jueces constitucionales que en los sistemas de control concentrado o mixto anulan o invalidan leyes, y en algunos ordenamientos, determinan al legislador sobre la manera específica en la que éste debe legislar materias concretas. ${ }^{307}$

¿Cuál es la justificación para tal intervención?, ¿no se pone en riesgo la democracia?, ¿a quién representan los jueces? Estas preguntas como las primeras, ponen en cuestión al sistema democrático, al grado que algunos hablan ya de un gobierno de jueces. ${ }^{308}$ La dificultad contramayoritaria que significa la interpretación de constituciones conformadas preponderantemente por principios ${ }^{309}$ se ha intentado afrontar acudiendo a múltiples teorías. En algunas de ellas existe un pesimismo evidente, en otras, se intenta conciliar a la democracia con el papel que en ella juegan los jueces. Desde hace mucho tiempo, pero sobre todo ahora, existe una muy clara conciencia en el papel que los principios desarrollan en el modelo constitucional de derecho, se han dado respuestas diversas sobre la principal cuestión que señala:

...si el principio democrático establece que las decisiones que afectan a la colectividad deben ser adoptadas a través de un procedimiento en el que todos

307 Cárdenas Gracia, Jaime, La argumentación como derecho, op. cit., pp. 155-199.

308 Del Águila, Rafael, La Senda del Mal, Política y Razón de Estado, Madrid, Taurus, 2000, p. 293 y ss.

309 Bickel, Alexander, The Least Dangerous Branch, New Haven, Yale University Press, 1962, p. 16. 
Este libro forma parte del acervo de la Biblioteca Jurídica Virtual del Instituto de Investigaciones Jurídicas de la UNAM

puedan participar con su voz y con su voto, bajo la regla de la mayoría, y si en las condiciones actuales de la modernidad ese principio abstracto se concreta en el establecimiento de un sistema representativo en el que un Parlamento elegido periódicamente por sufragio universal toma decisiones por mayoría, entonces, ¿por qué deberían someterse las decisiones a un ulterior control judicial? ${ }^{310}$

Algunas de las soluciones proponen una interpretación que asuma los presupuestos democráticos, como es el caso de Ely; ${ }^{311}$ otras aluden a la soberanía constitucional; 312 otras plantean la reducción de los poderes interpretativos del juez - Kelsen y los originalistas norteamericanos-; otras sostienen la legitimidad judicial a partir de las garantías orgánicas y funcionales de independencia e imparcialidad judicial, ${ }^{313}$ algunas hacen consistir la legitimidad del juez en la calidad de su argumentación para vislumbrar la única respuesta correcta en los casos difíciles, ${ }^{314}$ y otras proponen nuevos diseños institucionales en el poder judicial que propendan a una democracia más deliberativa y participativa, ${ }^{315}$ y así, un largo etcétera de soluciones en un ámbito en donde algunos son muy pesimistas. ${ }^{316}$

Por mi parte, sostengo lo siguiente: 1) los órganos garantes de los derechos merecen contar con legitimidad democrática directa de los ciudadanos para que sus titulares tengan responsabilidad directa frente a ellos y porque cualquier órgano cúspide del Estado debe ser expresión de la soberanía

310 Ferreres, Víctor, “Justicia constitucional y democracia”, en Carbonell, Miguel (comp.), Teoría de la Constitución. Ensayos escogidos, México, Porrúa-UNAM, 2002, pp. 247 y 248.

311 Ely, John, Democracy and Distrust. A Theory of Judicial Review, Cambridge, Harvard University Press, 1980.

312 Hamilton, Alexander et al., El federalista, México, Fondo de Cultura Económica, 1987. También véase la selección de artículos federalistas y antifederalistas en: Sánchez Cuenca, Ignacio y Lledó, Pablo, Artículos federalistas y antifederalistas. El debate sobre la Constitución americana, Madrid, Alianza, 2002.

313 Andrés Ibáñez, Perfecto, "Democracia con jueces", Claves de razón práctica, Madrid, núm. 128, diciembre 2002, pp. 4-11.

314 Dworkin, Ronald, El imperio de la justicia, Barcelona, Gedisa, 1988, pp. 44-71.

315 Nino, Carlos, Fundamentos de derecho constitucional, análisis jurídico y politológico de la práctica constitucional, Buenos Aires, Astrea, 1992, pp. 657 y ss.; mismo autor, "Los fundamentos del control judicial de constitucionalidad", Cuadernos y debates, Madrid, Centro de Estudios Políticos y Constitucionales, núm. 29, 1991, pp. 97 y ss.; Gargarella, Roberto, La justicia frente al gobierno. Sobre el carácter contramayoritario del poder judicial, Barcelona, Ariel, 1996, pp. 173 y ss.

316 Troper, Michel, "El poder judicial y la democracia", en Malem, Jorge et al. (comps.), La función judical. Ética y democracia, Barcelona, Gedisa, 2003, pp. 209-233; mismo autor, Por una teoría jurídica del Estado, Madrid, Dykinson, 2001; Pintore, Anna, "Derechos insaciables", en Ferrajoli, Luigi, Los fundamentos de los derechos fundamentales, Madrid, Trotta, 2001, pp. 243-265. 
Este libro forma parte del acervo de la Biblioteca Jurídica Virtual del Instituto de Investigaciones Jurídicas de la UNAM

popular; 2) la historia constitucional de América Latina demuestra que los nombramientos de los titulares de las cortes constitucionales dependen del presidente o de las cúpulas de los partidos mayoritarios; 3) el hecho anterior limita su independencia porque suelen actuar y decidir como si fuesen correas de transmisión de los intereses y voluntad de quien los designó; 4) por el mecanismo de designación, los órganos constitucionales autónomos se han partidocratizado y se conducen en atención a ese hecho; 5) no suele haber pluralismo jurídico, político o ideológico entre los titulares de estos órganos porque éstos representan y reproducen las concepciones jurídicas o políticas de las clases dominantes; 6) por el método de designación existente, los titulares de esos órganos pierden independencia porque con motivo de sus funciones no afectarán los intereses de quién los nombró, ya sea el Ejecutivo, el Congreso o cualquier otra instancia de autoridad o conjunción de éstas; 7) los órganos constitucionales autónomos, que tienen facultades para anular o invalidar leyes con efectos generales, actúan como poderes contramayoritarios, capaces de anular o desaplicar normas jurídicas que han sido aprobadas por las mayorías o por los representantes de éstas; 8) el método de designación más el estatuto de sus titulares los transforma en órganos elitistas; 9) el método de designación no les permite generar vínculos con la ciudadanía ni promueve la rendición de cuentas a la sociedad, y 10) sus titulares resuelven de espaldas a la sociedad, y por lo mismo, no sienten que estén allí para garantizar las necesidades, los intereses y los derechos de los ciudadanos, sino los intereses y privilegios de los dirigentes y beneficiarios del status quo.

La elección por sufragio universal de los titulares de los poderes judiciales ha existido en América Latina. Además del caso boliviano vigente, el método de elección popular de los titulares del Poder Judicial fue una realidad para los ministros de la Suprema Corte, el fiscal y el procurador en la Constitución mexicana de 1857. El profesor José María del Castillo Velasco, que fue constituyente de esa Ley Suprema, en su obra Apuntamientos para el estudio del derecho constitucional mexicano señala textualmente:

Mientras el poder judicial se considere...como ramo de la administración pública, bien podría confiarse el nombramiento de los jueces al ejecutivo, ya por sí solo, ya con intervención del legislativo; pero desde el instante en que el ejercicio de las funciones judiciales se ha considerado como un verdadero poder público; desde el momento en que a ese poder se ha confiado la inviolabilidad de la Constitución, y el examen y el juicio de las leyes mismas con 
Este libro forma parte del acervo de la Biblioteca Jurídica Virtual del Instituto de Investigaciones Jurídicas de la UNAM

relación a la ley suprema, no puede confiarse la elección de los jueces sino al pueblo... 317

Daniel Cosío Villegas en su obra La Constitución de 1857 y sus críticos, compara a los ministros de la Suprema Corte de Justica de México de mediados del siglo XX con los ministros derivados del método de elección de la Constitución de 1857 y concluye que éstos últimos eran, entre otras cosas, debido al método de elección ciudadano, “...independientes, fiera, altanera, soberbia, insensata, irracionalmente independientes...". 318

En este sentido, la vía de nominación o de selección de los titulares de los órganos constitucionales autónomos no es indiferente, es fundamental. La nominación, si depende de los poderes formales o de los poderes fácticos, puede estar condicionada por la ideología política, los intereses y hasta las instrucciones de quien nombra. En Estados Unidos es bastante conocida la posición de Jeremey Waldron en contra del carácter contramayoritario de la Corte Suprema de ese país ${ }^{319}$, y por eso, insiste en que la revisión de constitucionalidad debe permanecer en el Congreso.

La elección por sufragio universal de los titulares de las cortes constitucionales podría comportar críticas e inconvenientes, sobre todo si los candidatos a ocupar esos cargos son postulados por los partidos políticos, reciben financiamiento público o privado o realizan campañas. Para evitar esos inconvenientes es importante que los candidatos a ocupar las titularidades de las cortes constitucionales no sean postulados por los partidos políticos, para que no exista dependencia respecto a ellos; también debe prohibirse que esos candidatos reciban financiamiento público o privado o que realicen campañas, porque ello los haría dependientes de intereses económicos, mediáticos o de otra índole. El método ideal de elección de los titulares de las cortes constitucionales debe comprender tres etapas: 1) la realización de un examen de los aspirantes que cumplan los requisitos constitucionales y legales; 2) los diez primeros lugares por cada posición vacante deben tener acceso a tiempos gratuitos en radio y televisión para dar a conocer sus propuestas y sus ideas en torno a la orientación constitucional y social que debe a su juicio tener la corte constitucional, y 3 ) elección por voto ciudadano al

317 Castillo Velasco, José María del, Apuntamientos para el estudio del derecho constitucional Mexicano, México, Miguel Ángel Porrúa, 2007, p. 203.

318 Cosío Villegas, Daniel, La Constitución de 1857 y sus críticos, 2a. ed., México, Fondo de Cultura Económica-Clío, 2007, p. 102.

319 Waldron, Jeremy, The Dignity of Legislation, Cambridge, Cambridge University Press, 1999. 
Este libro forma parte del acervo de la Biblioteca Jurídica Virtual del Instituto de Investigaciones Jurídicas de la UNAM

momento de la elección del resto de los cargos públicos de elección popular, entre los diez finalistas por vacante. Estaría prohibido que los partidos u otros grupos económicos respaldaran a cualquiera de los diez finalistas. Considero que este método limitaría los inconvenientes de la elección de los titulares por sufragio universal, garantizaría su independencia de los poderes fácticos y de los partidos, y al tener un componente basado en el mérito, promovería el arribo de las y los mejores a estas posiciones.

En cuanto al principio de proporcionalidad, regla o método privilegiado para resolver las colisiones entre principios constitucionales, sólo hay que exponer las críticas de autores reconocidos y alguna propia. ${ }^{320}$ Habermas cuestiona a Alexy, al señalar que concebir a los derechos fundamentales como máximas de optimización, elimina el sentido deontológico de los derechos fundamentales, pues la concepción teleológica de los derechos llevaría a relativizar las posiciones iusfundamentales del individuo, de forma que los derechos fundamentales no serían cartas de triunfo frente a los objetivos estatales, sino únicamente valores objeto de ponderación con otros valores en cada situación concreta. La concepción teleológica de Alexy - según Habermas - debilita a los derechos fundamentales y favorece la realización de metas arbitrarias en contra de los individuos; es decir, la concepción de Alexy no se concilia con la tradición liberal que concibe a los derechos fundamentales como universales, inalienables y absolutos. ${ }^{321}$

La crítica de Habermas tiene seguidores en autores que sostienen que la aplicación de los derechos fundamentales mediante el principio de proporcionalidad es irracional y produce arbitrariedad; sirve para construir juicios salomónicos ${ }^{322}$ porque el propio principio de proporcionalidad es indeterminado conceptualmente, los principios constitucionales son, entre sí, inconmensurables e incomparables, y con el principio de proporcionalidad es imposible predecir resultados. Sobre la indeterminación conceptual del principio de proporcionalidad se dice que no existen criterios jurídicos que sean vinculantes para el juez y que puedan utilizarse para controlar las decisiones judiciales en las que se ponderan principios. El principio de

320 Cárdenas Gracia, Jaime, Manual de argumentación jurídica, op. cit., pp. 206-210. En esa obra intento salvar las críticas del principio de proporcionalidad pero encuentro ahora que mis argumentos de respuesta no son suficientes.

321 Habermas, Jürgen, Facticidad y validez...op. cit., p. 278; mismo autor, La inclusión del otro, Barcelona, Paidós, 1999, p. 55; Arango, Rodolfo, "Concepciones deontológicas y teleológicas de los derechos fundamentales", en Clérico, Laura et al. (coords.), Derechos fundamentales, principios y argumentación, Granada, Comares, 2011, pp. 73-90.

322 Jiménez Campo, Javier, Derechos fundamentales. Concepto y garantías, Madrid, Trotta, 1999, p. 73. 
Este libro forma parte del acervo de la Biblioteca Jurídica Virtual del Instituto de Investigaciones Jurídicas de la UNAM

proporcionalidad es una estructura que se completa con las apreciaciones subjetivas del juez. Respecto a la incomparabilidad y la inconmensurabilidad de los principios constitucionales que se ponderan se argumenta que los principios constitucionales entre sí no son comparables porque son diferentes entre sí, y en cuanto a la inconmensurabilidad se indica que al no existir una relación jerárquica entre los principios constitucionales ni una medida en común entre ellos, es imposible determinar el peso de cada principio. Finalmente, el principio de proporcionalidad no garantiza predecir los resultados de la ponderación, y en consecuencia, la jurisprudencia derivada de la aplicación del principio de proporcionalidad siempre será ad hoc - caso por caso y a posteriori-, es incapaz de generar criterios generales, lo que desdora la seguridad jurídica del ordenamiento. ${ }^{323}$

Enlazadas con las anteriores críticas, se dice también que al ponderar los tribunales constitucionales, que carecen de legitimidad democrática, intervienen ilegítimamente en las competencias que la Constitución confiere a otros poderes del Estado, principalmente al poder legislativo. ${ }^{324}$ Según esas críticas el tribunal constitucional sustituye y ocupa el lugar de la Constitución - la Constitución dice lo que quiere que diga el tribunal constitucional- y las diversas y hasta contradictorias decisiones subjetivas que emite el tribunal constitucional anulan las decisiones democráticas que el legislador ha tomado. El principio de proporcionalidad es una herramienta que se han inventado los tribunales constitucionales para legitimarse y para intervenir indebidamente en decisiones políticas. Así como los tribunales constitucionales intervienen indebidamente en las competencias del legislador, también intervienen en las competencias de la jurisdicción ordinaria, pues las decisiones de los primeros constitucionalizan el derecho ordinario mediante la irradiación de sus decisiones y a través de vías como la acción o juicio de amparo.

Existen además otro tipo de críticas respecto al principio de proporcionalidad. Una de ellas, es la del profesor español Juan Antonio García Amado, quien sostiene que el principio de proporcionalidad supone entender, que subyacente a la Constitución formal, existe otra que es la Constitución

323 Para mayor profundidad sobre el tema: Bernal Pulido, Carlos, “¿Es la ponderación irracional y contraria al principio democrático? Una discusión sobre la teoría de los derechos fundamentales como principios en el contexto de España?", en Sieckmann, Jan-Reinard (ed.), La teoría principalista de los derechos fundamentales. Estudios sobre la teoría de los derechos fundamentales de Robert Alexy, Madrid, Marcial Pons, 2011, pp. 228 y 229.

324 Por ejemplo, véase Waldron, Jeremy, The Dignity of Legislation, Cambridge, Cambridge University Press, 1999, pp. 158-160. Sobre esta discusión véase Cárdenas Gracia, Jaime, La argumentación como derecho, México, UNAM, 2005, pp. 155-199. 
Este libro forma parte del acervo de la Biblioteca Jurídica Virtual del Instituto de Investigaciones Jurídicas de la UNAM

material, la que hace ilusoriamente aparecer a la primera como un sistema claro, coherente y pleno. La Constitución material concreta e institucionaliza la moral social o política vigente. Los tribunales constitucionales resuelven y dotan de contenidos a los principios constitucionales empleando los principios morales de esa moral, los que no pueden tener un significado objetivo en una sociedad abierta y democrática y, por ello, sus decisiones son, no sólo discrecionales sino irracionales. ${ }^{325}$

Además de lo anterior, estimo que el principio de proporcionalidad es un método que al buscar la conciliación y la armonización entre los principios, favorece el mantenimiento de lo establecido. Es un instrumento de pacificación social, política y económica. Como tal, favorece a los intereses del status quo y carece de la capacidad transformadora de esa realidad. La proporcionalidad simplemente pretende determinar qué principio prevalece en el caso concreto, pero no se propone hacer de él, un mecanismo de cambio social o económico. En este sentido, es un método conservador que viene a beneficiar a los intereses económicos, sociales y políticos que respaldan la realidad existente. Su capacidad de manipulación no va a ir en contra de las expectativas de las respectivas oligarquías dominantes o hegemónicas, ya sea de las naciones o del espacio supranacional. Con el principio de proporcionalidad se podrá abundar y adicionar en los ámbitos de lo políticamente correcto, de la moral prevaleciente; pero nunca este principio servirá para trastocar los modelos económicos, políticos o simbólicos de dominación.

¿Qué son las teorías del Estado constitucional? Construcciones jurídicas que desean el noble sueño de la realización de los derechos humanos, pero que se enfrentan a la amarga pesadilla de la realidad, pues algunos de esos derechos - los de igualdad - no pueden ser realizados sin trastocar el modelo capitalista de dominación. Son teorías que desconfían de las posibilidades de una democracia radical, de la importancia de un nuevo diseño de las instituciones, que no atienden al modelo de dominación vigente - el neoliberal globalizador-, que ven por encima del hombro a las concepciones comunitarias y multiculturalistas, que ingenuamente piensan que el concepto de democracia constitucional es para salvaguardar los derechos de los débiles, cuando en realidad con él, protegen los derechos de los poderosos, que son la minoría en las naciones y en el planeta. Son teorías profundamente elitistas, oligárquicas y antidemocráticas, porque confían a grupos tecnocráticos de expertos en derechos humanos la determinación y el alcan-

325 García Amado, Juan Antonio, “¿Existe discrecionalidad en la decisión judicial? O de cómo en la actual teoría del derecho (casi) nada es lo que parece y (casi) nadie está donde dice”, Berbiquí, núm. 30, 2005, pp. 14 y ss. 
Este libro forma parte del acervo de la Biblioteca Jurídica Virtual del Instituto de Investigaciones Jurídicas de la UNAM

ce de los mismos. En fin, son teorías que no tocan el nervio de los modelos de dominación capitalista neoliberal y globalizadores vigentes, pero tristemente les brindan un servicio de legitimación jurídica para mantener la ilusión de que a través del derecho son posibles las transformaciones, aunque tal vez eso de suyo ya sea importante. 
Este libro forma parte del acervo de la Biblioteca Jurídica Virtual del Instituto de Investigaciones Jurídicas de la UNAM

\section{CAPÍTULO QUINTO}

\section{EL ESTADO NEOLIBERAL 326}

\section{LA GLOBALIZACIÓN NEOLIBERAL RESPALDADA POR CONCEPGIONES GEOPOLÍTICAS}

La geopolítica estudia las prácticas políticas, militares, diplomáticas, económicas, ideológicas y culturales, en manos de las grandes potencias del mundo y de los Estados que se les oponen, con el propósito de controlar en su beneficio hegemónico los territorios, la población y los mercados de otros Estadosnación y sus recursos. Esas prácticas están vinculadas a visiones hegemónicas del control o influencia mundial que se disputan entre sí los países más importantes del planeta. La geopolítica expone las narraciones a favor de esas prácticas al igual que los puntos de vista críticos sobre los esfuerzos de control o influencia mundial que ejercen las grandes potencias. ${ }^{327}$

Los procesos de globalización neoliberal dominantes son la expresión de las concepciones geopolíticas de las grandes potencias. ${ }^{328}$ Muchos de los cambios sucedidos en el concierto mundial y en el de las naciones Estado en las últimas décadas responden al interés, no sólo de los organismos financieros mundiales, o al derivado de los acuerdos comerciales internacionales, o al promovido por las grandes corporaciones internacionales o por los mercados, sino al interés de los gobiernos más importantes del planeta, que ven en los procesos de globalización la oportunidad para incrementar su hegemonía mundial a través del mayor control sobre los territorios, la población, los mercados de otros Estados, y principalmente, sobre sus recursos. La globalización neoliberal es un proyecto geopolítico que impide que la globalización pueda expresarse o manifestarse de maneras más sociales, de abajo hacia arriba, esto es, que pueda construirse una globalización contra-hegemónica.

326 Este capítulo retoma con adecuaciones algunos elementos y temas que he tratado en el libro de mi autoría, El modelo jurídico del neoliberalismo, México, UNAM, 2016.

327 Flint, Colin, Introduction to Geopolitics, Nueva York, Routledge, 2012, pp. 4-30.

328 Stiglitz, Joseph E., Cómo hacer que funcione la globalización, Madrid, Santillana Ediciones Generales, 2006, p. 25. 
Este libro forma parte del acervo de la Biblioteca Jurídica Virtual del Instituto de Investigaciones Jurídicas de la UNAM

El neoliberalismo es una teoría geopolítica de dominación y no sólo es una estructura económica, sino un esquema integral que conjuga la violencia política, militar, ideológica, jurídica y estatal, para que las transformaciones estructurales que promueve a nivel nacional y global, pongan a las anteriores variables de su lado con el propósito de modificar, en beneficio de las clases dominantes, los elementos que conforman la convivencia social de la nueva forma de dominación política. ${ }^{329} \mathrm{El}$ neoliberalismo globalizador es entonces, no sólo una herramienta de la geopolítica, sino la manera contemporánea en la que se realizan las vías de la geopolítica.

Muchos ejemplos existen de lo anterior. La promoción de los tratados y acuerdos internacionales de carácter comercial, de seguridad, medioambientales, de derechos humanos, corresponde realizarla, casi siempre, a los gobiernos de las grandes potencias para conformarlos a sus deseos e intereses; así como a los requerimientos de los organismos financieros internacionales y a las determinaciones de los acuerdos de libre comercio y de las grandes empresas trasnacionales. Arturo Oropeza explica, con motivo del probable Acuerdo de Asociación Transpacífico, cómo el gobierno de los Estados Unidos ha sido el principal promotor de ese acuerdo, y cómo esa negociación va más allá de los temas estrictamente comerciales y se inscribe en las lógicas del conflicto geopolítico entre el gobierno chino y el norteamericano. Oropeza ilustra con once preguntas esa tensión:

1. ¿El TPP forma parte de la lucha de Occidente frente Asia del este por la supremacía del siglo XXI?, 2. ¿Es una confrontación entre países o civilizaciones?, 3. ¿El TPP es parte de las primeras expresiones geopolíticas del traslado de una Era del Atlántico a una Era del Pacífico?, 4. ¿Representa el fin del autismo norteamericano respecto al heterodoxo dinamismo chino?, 5. ¿Es parte de la lucha entre Estados Unidos y China por el liderazgo del siglo XXI?, 6. ¿Es la respuesta de Estados Unidos a la penetración de China en América Latina?, 7. ¿Es una estrategia paralela de Estados Unidos ante el congelamiento de la Organización Mundial de Comercio (OMC)?, 8. ¿Es una embestida norteamericana para ampliar la protección de su sector de servicios sin renunciar a sus privilegios en el sector agrícola?, 9. ¿Es una propuesta alterna a la OMC para extender los derechos de las compañías norteamericanas en materia farmacéutica, tecnologías de la información y propiedad intelectual en general?, 10. ¿Es la novación del Tratado de Libre Comercio de América del Norte (TLCAN), ante la pasiva mirada de México y Canadá? y 11. ¿Es la

329 Harvey, David, Breve historia del neoliberalismo, op. cit.; mismo autor, El nuevo imperialismo, Madrid, Akal, 2004; mismo autor, El enigma del capital y la crisis del capitalismo, Madrid, Akal, 2012; mismo autor, Seventeen Contradictions and the End of Capitalism, Oxford-Nueva York, Oxford University Press, 2014. 
Este libro forma parte del acervo de la Biblioteca Jurídica Virtual del Instituto de Investigaciones Jurídicas de la UNAM

ampliación del TLCAN sin necesidad de ajustar los desbalances registrados en los últimos veinte años?. ${ }^{330}$

El caso expuesto por Oropeza nos ayuda a entender cómo los proyectos geopolíticos de las grandes potencias están vinculados a la manera en la que se desenvuelve la globalización mundial, de arriba hacia abajo, desde una visión elitista, en donde lo fundamental es el acrecentamiento del poder de la respectiva potencia y los beneficios para las élites económicas mundiales que sostienen esas concepciones hegemónicas. En los proyectos geopolíticos no importan los beneficios para las sociedades nacionales ni los derechos fundamentales de las personas; muchos ejemplos existen al respecto y confirman lo que aquí aseveramos.

En México, los que estudian los efectos y consecuencias del TLCAN para la economía nacional y para la sociedad mexicana, explican que

...la institucionalización del comercio libre, sobre todo sí es acelerada, no significa cambios sustanciales en la reorientación de los flujos comerciales y la misma no resulta tan favorable como se esperaba en términos de creación de empleos o transferencia de tecnología... Contrario a lo que se esperaría, el patrón de dependencia de la economía norteamericana no se ha convertido en una interdependencia simétrica... ${ }^{331}$

Esto es, México ha perdido una buena parte de su planta productiva, ha visto afectado su dinamismo económico, y la economía nacional no ha podido crecer anualmente desde los años ochenta más allá del 2\%.

Las características de los proyectos geopolíticos de las grandes potencias sobre el resto de los Estados y respecto a los ritmos y alcances de la globalización neoliberal, dependen de muchas variables, entre ellas: la proximidad geográfica entre los territorios; la manera en que históricamente han interactuado los países; la vastedad de los recursos naturales en juego; la importancia de esos recursos para ciertas actividades estratégicas; las condiciones democráticas o no de los gobiernos nacionales; la fortaleza de las sociedades nacionales para oponerse a algunas variables de la globalización, etcétera. Lo que implica que los procesos de globalización son manifestación dependiente de los proyectos geopolíticos en curso.

330 Oropeza García, Arturo, El acuerdo de asociación transpacifico. ¿Bisagra o confrontación entre el Atlántico y el Pacífico?, México, UNAM, 2013, p. 14.

331 Haro Navejas, Francisco Javier, "La nueva institucionalización mundial: China, India, Japón y Tailandia frente al TTP", en Oropeza García, Arturo, El acuerdo de asociación transpacífico. ¿Bisagra o confrontación entre el Atlántico y el Pacífico?, op. cit., pp. 73 y 74. 
Este libro forma parte del acervo de la Biblioteca Jurídica Virtual del Instituto de Investigaciones Jurídicas de la UNAM

En nuestro caso, la relación geopolítica entre los Estados Unidos y México proviene desde hace mucho tiempo, desde nuestra independencia, y se ha incrementado en las últimas décadas de manera cada vez más asimétrica por el deseo cada vez más acuciante de los gobiernos norteamericanos de tener el control sobre el territorio, la población y los recursos estratégicos de nuestro país. El TLCAN estableció ritmos acelerados de integración y de subordinación de México a los Estados Unidos, sin que, por ejemplo, inicialmente la materia energética formara parte de ese acuerdo. Posteriormente, el ASPAN (Acuerdo para la Seguridad y Prosperidad de América del Norte) firmado por los gobiernos de Estados Unidos, Canadá y México en 2005, sin intervención del Senado mexicano, promovió la integración profunda en materia energética. El ASPAN tuvo entre sus finalidades garantizar el abasto de energía de México y Canadá hacia los Estados Unidos (los Estados Unidos requieren para el mantenimiento de su economía de 19 millones de barriles de petróleo al día y sólo producen 8 millones), lo que se ha confirmado con la reciente reforma energética nacional, que propone incrementar la producción de petróleo de México de 2.4 millones a 3.5 millones de barriles al día, con el objetivo de que México venda sus excedentes a la economía norteamericana; esto implicaría más de un millón y medio de barriles diarios, ${ }^{332}$ sin que importe a la elite nacional o a la estadounidense el desarrollo de la industria petroquímica - que a México le redituaría más dividendos - la protección de las reservas mexicanas, la defensa del medio ambiente o la salud.

Durante el debate energético en México de 2013-2014, los sectores favorables a la reforma energética, no advirtieron o no quisieron advertir, los riesgos que implica ese cambio para integrarnos de manera subordinada a la estrategia de seguridad energética de América del Norte, principalmente de los Estados Unidos. ${ }^{333}$ Hubo voces, como las de Rosío Vargas y John Saxe Fernández, entre otras, que señalaban esos riesgos. Para Rosío Vargas, en la reforma energética de 2013-2014 no existió un análisis suficiente y serio que tomara en cuenta la influencia y la hegemonía de los Estados Unidos en la industria energética mundial. En el esquema del poder mundial, los Estados Unidos históricamente han pretendido salvaguardar ante todo su seguridad energética por encima de la seguridad energética de las otras na-

332 Vargas Suárez, Rosío, El papel de México en la integración y seguridad energética de Norteamérica, México, UNAM, 2014, pp. 30 y 31.

333 Jalife-Rahme, Alfredo, Muerte de PEMEX y suicidio de México, México, Grupo Editor Orfila Valentini, 2014. Este autor señala que la finalidad fundamental de la reforma energética de 2013-2014 es la de salvaguardar los intereses geoestratégicos de los Estados Unidos y beneficiar a las grandes empresas petroleras de carácter privado del mundo. 
Este libro forma parte del acervo de la Biblioteca Jurídica Virtual del Instituto de Investigaciones Jurídicas de la UNAM

ciones para mantener su desarrollo económico, industrial y militar, el que depende fundamentalmente de los hidrocarburos. En la reforma energética mexicana de 2013-2014, sus promotores nacionales expresaron que Estados Unidos en pocos años sería autosuficiente en energía y no necesitaría más del petróleo ni gas de países como México. Esas aseveraciones son incorrectas si la confrontamos con la información oficial del gobierno de los Estados Unidos, específicamente con la del Departamento de Energía de ese país, la que pone de manifiesto que los Estados Unidos continuarán siendo importadores de petróleo hasta, al menos, el año de 2040. En la reforma energética 2013-2014 fue penoso que el gobierno mexicano no reconociera que el cambio jurídico, con su pretensión de incrementar diariamente la producción nacional en más de un millón de barriles de petróleo crudo al día - respecto a los volúmenes actuales - tiene por propósito seguir abasteciendo al mercado de energía de los Estados Unidos con grave daño al futuro energético de México. La reforma energética mexicana subordinó el interés nacional y la soberanía de México a la seguridad energética de los Estados Unidos. ${ }^{334}$

Saxe-Fernández señala, al igual que Rosío Vargas, que la reforma energética de 2013-2014 busca flexibilizar la Constitución Mexicana de 1917 para privatizar y extranjerizar la principal palanca del desarrollo del país. ${ }^{335}$ Este autor indica que inmediatamente después de la expropiación y nacionalización del petróleo de 1938, los Estados Unidos y las empresas petroleras expropiadas decidieron regresar y controlar la industria energética nacional. A los Estados Unidos siempre les ha preocupado que el vecino del sur contara con una industria energética de naturaleza pública y exitosa porque ese paradigma podría trasladarse a otras latitudes geográficas, y lo más grave para ellos, podría poner en riesgo la influencia y el poder de las grandes corporaciones norteamericanas en el mundo entero. El modelo mexicano de industria energética pública ha estado desde hace décadas en la mira del gobierno norteamericano y de los organismos financieros internacionales como el Banco Mundial, el Fondo Monetario Internacional y el Banco Interamericano de Desarrollo. El esquema nacional de la energía en México comenzó a debilitarse desde 1982, con la crisis de la deuda externa de México y su renegociación. Los Estados Unidos, a partir de esos años,

334 Vargas Suárez, Rosío, "El contexto geopolítico y la iniciativa de reforma energética del PRIAN", en Cárdenas Gracia, Jaime (coord.), Reforma energética: análisis y consecuencias, México, UNAM-Tirant Lo Blanch, 2015, pp. 169 y ss.

335 Saxe Fernández, John, "Flexibilización constitucional y el reingreso a México de las petroleras nacionalizadas por Lázaro Cárdenas”, en Cárdenas Gracia, Jaime (coord.), Reforma energética: análisis y consecuencias, op. cit., pp. 183 y ss. 
Este libro forma parte del acervo de la Biblioteca Jurídica Virtual del Instituto de Investigaciones Jurídicas de la UNAM

fueron imponiendo condiciones a la industria energética mexicana en aras de privatizarla y para que ya no fuera el motor de la industrialización ni de la economía nacional y, en consecuencia, dejara de ser referente alternativo de desarrollo para otras naciones. Saxe Fernández demuestra que países como Brasil, que han realizado antes que México la privatización parcial de los recursos energéticos, no han obtenido para sus sociedades grandes beneficios y que, por el contrario, han sido expoliadas por los objetivos extractivos de las grandes empresas petroleras mundiales. Con fundamento en la obra de Steve Coll, ${ }^{336}$ Saxe-Fernández describe los roles de esas empresas trasnacionales y las consecuencias negativas que para las sociedades de distintas naciones tienen; considera que la reforma energética de 2013-2014 se hizo a la medida de los intereses de esas empresas y del gobierno de los Estados Unidos.

Otra herramienta importante de la geopolítica contemporánea es la construcción del Estado policíaco-militar para las necesidades y fines del Estado neoliberal. En un estudio chileno, publicado por el Centro de Estudios Miguel Enríquez, se indica que un Estado policial se caracteriza por:

1) Ser un Estado que mantiene un estricto control social, en donde se pueden suprimir algunas libertades civiles, además de legitimar a una policía secreta que coadyuve con los fines del control; 2) Para que sea legítimo el control social, el Estado crea enemigos, éstos pueden ser el terrorismo, la lucha contra las drogas, el crimen organizado, etcétera; 3) A diferencia de los Estados democráticos, en el Estado policial, la seguridad no tiene fundamento en los derechos humanos ni en la voluntad democrática de las sociedades, sino en la noción de control social, la que es impuesta desde el gobierno; 4) El Estado policial puede conservar algunos elementos del Estado democrático pero adopta algunos elementos de los Estados fascistas, como leyes arbitrarias, excesivo control social y subordinación de los medios de comunicación para que éstos respalden la conveniencia del control; 5) El Estado policial es una expresión de la globalización neoliberal contemporánea, porque las empresas trasnacionales necesitan que los Estados, mediante la represión policíaca, protejan sus inversiones y sus intereses; 6) Es por ello que hay una incesante demanda por parte de los intereses trasnacionales de incrementar el poder de fuerza y de la represión por parte de las policías y del ejército; 7) La profesionalización y capacitación de policías y militares no se realiza desde una perspectiva de derechos humanos para proteger a las sociedades, sino se entiende que el uso de la fuerza es para reprimir a las sociedades si éstas demandan vías alternativas de convivencia; 8) En el Estado policiaco se criminaliza la

336 Coll, Steve, Private Empire: Exxon Mobil and American Power, Londres-Nueva York, Penguin, 2013. 
Este libro forma parte del acervo de la Biblioteca Jurídica Virtual del Instituto de Investigaciones Jurídicas de la UNAM

protesta y los movimientos sociales; entre otras cosas, se asimila la protesta con el terrorismo o la delincuencia, y 9) Se busca que la policía y los militares tengan un régimen jurídico de excepción para garantizarles altos niveles de impunidad por las conductas que los involucran. ${ }^{337}$

En un estudio nacional de Jaime A. Preciado Coronado y de Ángel L. Florido Alejo, profesores de la Universidad de Guadalajara y titulado: "La militarización de las relaciones México-Estados Unidos; espacios ingobernables y ¿Estado fallido?”, se explica en clave geopolítica, con abundante información, el avance del ejército mexicano en tareas de seguridad que no les competen constitucionalmente. ¿Por qué interviene el Ejército mexicano en tareas policíacas? Para controlar a la sociedad mexicana por mandato externo, y para ello, recurren a una doctrina de seguridad nacional en constante y acelerada evolución. Así, asumen intencionalmente confusiones conceptuales para mezclarlas entre ellas y mantener en constante incremento su fuerza e influencia política. Por ejemplo, se confunden e intercambian las categorías de seguridad pública y seguridad nacional; se prioriza la inteligencia y la manipulación mediática con el terrorismo y la seguridad sobre otras consideraciones internas; se mezcla la incidencia del crimen organizado con los movimientos contestatarios; se promueve el miedo y el terror social a través de los medios de comunicación; se intenta que la sociedad vea con normalidad el intercambio de información y tareas entre las fuerzas militares nacionales y las norteamericanas; se justifica que el gobierno de los Estados Unidos tenga responsabilidad en la seguridad de su frontera sur; se abastece constantemente al ejército y a las policías mexicanas de armas y equipos; se promueven y materializan planes de seguridad de América del Norte como la Iniciativa Mérida y el ASPAN, y ahora por medio de las Cumbres de las Américas; se justifica la integración de las fuerzas policiales nacionales y militares con proyectos de integración neopanamericanos; se debilita al Estado democrático y se exponen las deficiencias del Estado mexicano empleando el concepto de Estado fallido, que fue creado por la inteligencia norteamericana, y se justifica, con la existencia en México de elementos de ese Estado fallido, la intervención de los Estados Unidos para concebir políticas de seguridad hegemónicas, de control y de integración, tanto en América del Norte como en América del Sur. ${ }^{338}$

337 Centro de Estudios Miguel Enríquez, "Estado policial. Una aproximación al concepto", Chile, Archivo Chile-Taller Rodriguista, 2005.

338 Preciado Coronado, Jaime A., y Florido Alejo, Ángel L., "La militarización de las relaciones México-Estados Unidos; espacios ingobernables y ¿Estado fallido?", US National 
Este libro forma parte del acervo de la Biblioteca Jurídica Virtual del Instituto de Investigaciones Jurídicas de la UNAM

El Estado policíaco-militar es, por tanto, una construcción teórica que explica la constante militarización en el mundo y en nuestra nación. Este tipo de Estado es una faceta de análisis geopolítica del Estado neoliberal. Se ha incrementado inmensamente el poder de los ejércitos y policías para tutelar el modelo económico del Estado neoliberal. Las grandes potencias, como los Estados Unidos, se asumen responsables del proceso para mantener condiciones aceptables de reproducción del capitalismo contemporáneo en beneficio de las grandes empresas trasnacionales y apuntalar sus áreas de influencia en la lucha por la hegemonía mundial. Por eso, países como México han recibido el impacto de esta concepción geopolítica - sobre todo porque constituimos la frontera sur de los Estados Unidos - y sin importar nuestras estructuras políticas formales o las necesidades domésticas, el modelo del Estado policiaco-militar se impone, y los gobiernos cómplices lo reciben con agrado y sin oponerse, para no agraviar a la potencia. Sin embargo, es tan nociva esta nueva estructuración del Estado, que en los propios Estados Unidos, la violencia policiaca militar ha provocado en muchas ciudades reacciones contrarias y de oposición por parte de la sociedad civil. ${ }^{339}$

Lo anterior corrobora cómo el modelo de globalización económica neoliberal cuenta con motores geopolíticos que no son exclusivamente económicos, sino políticos, militares, diplomáticos, ideológicos y desde luego, jurídicos. La geopolítica está imbricada en el modelo de globalización económica neoliberal; sin ella no se puede explicar por qué los procesos de globalización neoliberal presentan sus características contemporáneas. Sin esa variable tampoco podríamos estudiar adecuadamente los ritmos, condiciones y profundidad de los procesos globalizadores.

\section{LA GLOBALIZACIÓN NEOLIBERAL}

La actual fase del neoliberalismo globalizador se corresponde con una configuración específica del Estado y del derecho. A consecuencia del impulso al gran capital, en el ámbito jurídico mundial, se crean redes internacionales de regulación por encima de la voluntad del Estado - principalmente de sus sociedades - y de los paradigmas tradicionales del derecho (estatalidad en la producción de normas jurídicas, jerarquía normativa a partir de la

Security Concerns in Latin America and the Caribbean, Nueva York, Palgrave MacMillan, 2014, pp. 61-79.

339 Chamseddine, Roqayah, "La militarización de las agencias de policía. Desde Ferguson hasta el Medio Oriente", Colectivo todo poder al pueblo, California, Estados Unidos de América, 2014. 
Este libro forma parte del acervo de la Biblioteca Jurídica Virtual del Instituto de Investigaciones Jurídicas de la UNAM

Constitución, poderes de los Congresos de cada Estado para definir los propios diseños institucionales estaduales, jurisdicción a cargo exclusivamente de tribunales nacionales, etcétera). ${ }^{340}$ Las redes de regulación jurídica están integradas por instituciones trasnacionales, como el Fondo Monetario Internacional y el Banco Mundial, por grandes corporaciones mundiales, por gobiernos de las grandes potencias que impulsan esa visión de la realidad, por gobiernos de otras naciones que acatan de manera subordinada las decisiones de los centros de hegemonía mundial, pero en dichas redes están ausentes los ciudadanos de las sociedades nacionales. Los Estados-nación en función de su fuerza política y económica en el concierto mundial pueden, en algunos casos, negociar y disputar el contenido de su propio derecho; aunque generalmente, éste es recibido por los Estados-nación como algo ya dado que sólo debe formalizarse por los canales internos de cada país para que en los territorios nacionales y sobre las poblaciones respectivas tenga vigencia. De esta suerte, el derecho del Estado responde a concepciones externas, de carácter elitista, que obedecen a intereses económicos de unos cuantos y que muy pocas veces tienen que ver con los derechos, intereses y necesidades de las sociedades.

El modelo que creó el Estado-nación caracterizado por la centralización del poder en un gobierno que controla un territorio, la expansión del gobierno administrativo, la legitimación del poder a través de la teoría representativa y el monopolio de la fuerza concentrado en las fuerzas armadas y cuerpos de seguridad pública, ha sido sustituido por una nueva forma de Estado que se podría denominar trasnacional. La característica principal de este nuevo Estado es que las principales decisiones que afectan a las sociedades nacionales no se adoptan por los representantes electos de cada nación sino en sedes extra nacionales. Esas decisiones tienen que ver, principalmente, con las condiciones de vida de las sociedades y son tomadas por actores, instituciones y agentes no nacionales. Las resoluciones que se implementan en cada nación tienen como objetivo garantizar los procesos de acumulación del capitalismo mundial, favorecer a los grandes intereses económicos trasnacionales y nacionales, y en su caso, responder a lógicas geopolíticas que benefician a las grandes potencias mundiales, las que, por otra parte, están al servicio de los intereses económicos mundiales. De esta suerte, el poder ya no está centralizado en el Estado, sino que se encuentra deslocalizado en instituciones y agentes económicos supranacionales, el go-

340 Sousa Santos, Boaventura de y Rodríguez Garavito, César A., El derecho y la globalización desde abajo. Hacia una legalidad cosmopolita, Barcelona-México, Universidad Autónoma Metropolitana-Anthropos Editorial, 2007. 
Este libro forma parte del acervo de la Biblioteca Jurídica Virtual del Instituto de Investigaciones Jurídicas de la UNAM

bierno administrativo de cada Estado se reduce, flexibiliza y se ajusta a las necesidades del capitalismo mundial, los poderes extra nacionales no están legitimados democráticamente y el poder militar fundamental se localiza en las grandes potencias mundiales o en instituciones supranacionales controladas por esas potencias.

Estudiosos, como David Held, sostienen que la operación de los Estados-nación en este sistema mundializado o globalizado limita su autonomía y las posibilidades de la soberanía estatal como se entendió en el pasado. ${ }^{341}$ ¿Por qué? Porque las decisiones nacionales más importantes no se adoptan por las sociedades locales sino en instancias externas; porque la regulación jurídica nacional se debe adecuar a las necesidades del capitalismo mundial; porque la regulación trasnacional se considera jerárquicamente superior a la nacional, y por tanto, esa regulación no puede ser transgredida sin graves consecuencias para el Estado-nación, y porque las redes de regulación jurídica mundial complejizan y obstaculizan el funcionamiento de las autoridades locales que aparecen desconcertadas ante las realidades del nuevo derecho trasnacional.

Sin embargo, existen diversas aproximaciones teóricas sobre la globalización que se distinguen por los énfasis en la profundización de la globalización y sus efectos sobre el Estado-nación y sobre los ritmos históricos del proceso. Las posiciones sobre la globalización se suelen dividir en tres: la hiperglobalista o globalista, ${ }^{342}$ la escéptica y la transformacionalista. Desde la visión de los hiperglobalistas, la globalización se define como una nueva época de la historia humana en la que los Estados-nación son insostenibles en la nueva economía mundial; la globalización económica desnacionaliza a las economías pues han surgido nuevos actores en el sistema mundial con poder de decisión que impactan en el funcionamiento del Estado y de las sociedades particulares. La globalización económica, sus instituciones y agentes suplantarán al Estado-nación como unidad económica y política de la sociedad mundial. ${ }^{343}$ En el nuevo esquema surgen instituciones de gobernanza global que irán subordinando a las instituciones nacionales a sus decisiones y fines. Las características generales de la concepción hiperglobalista son: un reordenamiento de la acción humana que piensa y actúa, cada vez más, en términos globales; una era global y no nacional; capitalismo

341 Held, David, y McGrew, Anthony, Globalización-Antiglobalización..., op. cit.

342 Por ejemplo, Jessica Mathews considera que el Estado-nación tiende a disolverse porque habrá actores que tomarán decisiones al margen de él. Mathews, Jessica, "Power Shift", Foreign Affairs, vol. 76, núm. 1, 1997, pp. 65 y 66.

343 Held, David, y McGrew, Anthony, Globalización-Antiglobalización. Sobre la reconstrucción del orden mundial, op. cit., pp. 116 y 117. 
Este libro forma parte del acervo de la Biblioteca Jurídica Virtual del Instituto de Investigaciones Jurídicas de la UNAM

global, gobierno global y sociedad civil global; poder del Estado-nación en declive; las fuerzas conductoras de la globalización son el capitalismo neoliberal y la tecnología; erosión de las jerarquías nacionales; cultura mundial y no nacional; una trayectoria sostenida hacia una civilización global, y como última etapa, el fin del Estado-nación. ${ }^{344}$

Para los escépticos, el Estado-nación no ha perdido el poder. El Estado-nación sigue siendo uno de los actores fundamental para que el orden global funcione, aunque la tesis admite que el poder del Estado se ha configurado con el propósito de proteger a las economías que representan a la internacionalización con mayor fuerza. Para ellos, la globalización es una ideología o un mito necesario de los neoliberales para que los gobiernos nacionales disciplinen a sus ciudadanos, y así, satisfacer las exigencias del mercado neoliberal, que consisten en eliminar todos los obstáculos que se pretenda imponer a los intereses globales. Las características principales de la tesis escéptica son: reconocer la existencia de procesos de internacionalización y regionalización; los gobiernos nacionales se reconfiguran para satisfacer los intereses y necesidades del mercado neoliberal mundial; el poder de los gobiernos nacionales se incrementa para tutelar y beneficiar al mercado neoliberal; los Estados y los mercados son las fuerzas de la globalización; en el proceso de la globalización, los Estados-nación del sur tienen menos éxito que los del norte para imponer sus condiciones en la negociación económica y comercial del mercado mundial, y la internacionalización depende del acuerdo y apoyo de los respectivos Estadosnación. ${ }^{345}$

Los transformacionalistas consideran que la globalización reconfigura el poder en su conjunto - nacional y mundial-. ${ }^{346}$ La posición transformacionalista afirma que el derecho debería yuxtaponerse y entenderse en relación con la jurisdicción en expansión de las instituciones de la gobernanza internacional y las constricciones del derecho internacional, así como las obligaciones que de él se derivan. ${ }^{347}$ La globalización implica una relajación de las relaciones entre soberanía, territorialidad y poder político. Las ideas transformacionalistas las podemos caracterizar de la siguiente forma: el poder de los gobiernos nacionales y de las instancias mundiales se reestructura

344 Held, David et al., Global transformations. Politics, Economics and Culture, Stanford, California, Stanford University Press, 1999, pp. 3 y ss.

345 Held, David, y McGrew, Anthony, Globalización-Antiglobalización. Sobre la reconstrucción del orden mundial, op. cit., p. 16.

346 Slauther, Ann Marie, A New World Order, Princeton, Princeton University Press, 2004.

347 Held, David, y McGrew, Anthony, Globalización-Antiglobalización. Sobre la reconstrucción del orden mundial, op. cit., p. 146. 
Este libro forma parte del acervo de la Biblioteca Jurídica Virtual del Instituto de Investigaciones Jurídicas de la UNAM

para adaptarse a las nuevas circunstancias globales; se propende a constituir una nueva arquitectura del orden mundial; la globalización transforma el poder estatal y la política mundial, y los resultados de los procesos de globalización son inciertos. ${ }^{348}$

La exposición de estas tres visiones - hiperglobalizadores, escépticos y transformacionalistas - , independientemente de los énfasis en la velocidad del proceso de globalización o en la permanencia o desaparición del Estado, coinciden en tres aspectos que son torales para la argumentación que hacemos en estas páginas: la globalización se acuerda y se define por las élites económicas y políticas, tanto mundiales como nacionales; en los procesos de globalización no participan, activa ni extendidamente, las ciudadanías nacionales, y los procesos de globalización condicionan o reconfiguran al Estado-nación y a los órdenes jurídicos nacionales y mundiales en beneficio de los intereses económicos trasnacionales. Esto es, los procesos de globalización son instrumentos y cauces para el desarrollo del modelo económico neoliberal.

Las premisas anteriores son totalmente coincidentes con los procesos mundiales y nacionales en curso. Basta, para probar lo anteriormente senalado, revisar el llamado Consenso de Washington, el que se impuso mediante políticas públicas a nivel mundial, fundamentalmente a los países en desarrollo - aunque no sólo - para favorecer la liberalización de la economía mundial en pleno respaldo al modelo neoliberal globalizado. Las políticas del Consenso de Washington fueron resumidas por John Williamson y consisten en:

1) Disminuir el déficit presupuestario y jamás recurrir a la inflación para financiarlo; 2) El gasto público se debe apartar de aquéllas áreas que reciben recursos desproporcionados en relación con los beneficios económicos que se producen, tales como la administración, la defensa y los subsidios indiscriminados en gasto social; 3) Promover reformas tributarias para ampliar la base de los ciudadanos que deben contribuir y reducir las impuestos directos; 4) Lograr que las tasas de interés bancarias y financieras las determine el mercado; 5) Establecer criterios de cambio monetario unificados entre el mayor número de países, además de lograr que sean competitivos para estimular

348 Serna de la Garza, José María, Globalización y gobernanza: las transformaciones del Estado y sus implicaciones para el derecho público. (Contribución para una interpretación del caso de la guardería $A B C$ ), México, UNAM, 2010. Para este autor hay conceptos de la globalización fundamentales, como es el caso de gobernanza; para él, la gobernanza es la acción de los gobiernos nacionales y de las instituciones mundiales como una trama de relaciones entre las sociedades mundiales y nacionales, con las instituciones estatales y las corporaciones mundiales y organismos supranacionales para la gobernación. 
Este libro forma parte del acervo de la Biblioteca Jurídica Virtual del Instituto de Investigaciones Jurídicas de la UNAM

el crecimiento acelerado de exportaciones no tradicionales; 6) Liberalizar el comercio mundial a través de la celebración de acuerdos comerciales y mediante la reducción de los aranceles nacionales; 7) Estimular y proteger a la inversión extranjera directa; 8) Privatizar a las empresas estatales; 9) Desreglamentar para eliminar las normas que impiden la participación de nuevas empresas y que restringen la competencia, y 10) Fortalecer la propiedad privada sobre otras formas de propiedad. ${ }^{349}$

\section{LA SIGNIFICACIÓN ECONÓMICA E IDEOLÓGICA DEL NEOLIBERALISMO}

El neoliberalismo tiene sus fundamentos en la teoría neoclásica de la economía que se desarrolló en Inglaterra, Estados Unidos y el resto de Europa a finales del siglo XIX y principios del siglo XX. La teoría neoclásica cuenta entre sus grandes teóricos a Carl Menger (1840-1921), León Walras (18341910), Stanley Jevons (1835-1882) y Alfredo Marshall (1842-1924). Estos teóricos influirán posteriormente en autores neoliberales como Ludwig von Mises, Friedrich von Hayek y Milton Friedman, entre otros. La teoría neoclásica sostiene como principales tesis que: el estudio de la economía debe concentrarse en la utilización óptima de los recursos disponibles, que son escasos, para satisfacer las necesidades y deseos de los agentes económicos; la utilidad de los bienes y de los servicios, no es otra que la que representa, en el margen, para los consumidores; el equilibrio general corresponde a la utilización óptima de los recursos escasos, y se le puede identificar como un conjunto de valores para todas las variables, precios y cantidades que prevalecen de manera simultánea; los precios tienen significado como indicadores de la escasez (en relación a las preferencias de los consumidores), y la distribución del ingreso se determina por la contribución, que en el margen hacen los factores de la producción. ${ }^{350}$

Para los autores neoclásicos, el tema central de la economía está relacionado con la utilización óptima de los escasos recursos disponibles para satisfacer las necesidades y deseos que los agentes económicos experimentan en lo individual. El valor de las mercancías y de los servicios depende de la utilidad que les reporta a los consumidores. Estas visiones conceptuales fueron dominantes en el mundo económico hasta antes de la Gran Depresión de

349 Williamson, John, "What Washington Means by Policy Reform", Latin American Adjustment: How Much Has Happened?, Williamson, John (ed.), Washington, D. C., Peterson Institute for International Economics, abril, 1990, capítulo segundo.

350 Tello, Carlos e Ibarra, Jorge, La revolución de los ricos, México, UNAM, 2012, p. 45. 
Este libro forma parte del acervo de la Biblioteca Jurídica Virtual del Instituto de Investigaciones Jurídicas de la UNAM

1929. Después fueron sustituidas por el pensamiento keynesiano - hasta las crisis de los años setenta y ochenta del siglo XX - porque la teoría neoclásica no ofrecía una explicación adecuada de lo que estaba ocurriendo en esa etapa, principalmente, no tomaba en cuenta los aspectos contextuales en su análisis, en particular, el peso del Estado y sus regulaciones en la economía, así como el papel de las clases sociales.

El neoliberalismo económico, continuador de las teorías neoclásicas, constituye una visión extrema de esas teorías. Apuesta por la economía irrestricta del mercado y por un Estado que intervenga no para enfrentar las desigualdades sociales y económicas que provoca el mercado como lo hace el keynesianismo, sino para salvaguardar y extender la presencia del mercado; para proteger los intereses de las grandes trasnacionales; para garantizar su buen funcionamiento, y para enfrentar las barreras e impedimentos regulatorios a la libre competencia. El neoliberalismo puede ser estudiado en tres dimensiones: como ideología, como forma de gobierno y como paquete de medidas económicas. ${ }^{351}$

Entender al neoliberalismo como ideología implica asumir que sus piezas y elementos básicos constituyen el discurso dominante de nuestro tiempo, que las élites económicas y políticas lo consideran como dogma verdadero. La ideología neoliberal sostiene una imagen idealizada del libre mercado y estima que los individuos son seres descontextualizados y egoístas que sólo persiguen su interés y satisfacción mediante el consumo. El neoliberalismo como ideología recela de la intervención económica del Estado en la economía a menos que sea para favorecer al gran capital especulativo y financiero, ${ }^{352}$ condena a las empresas públicas, rechaza el rol del sindicalismo reivindicativo, descarta las negociaciones colectivas obrero-patronales, desconfía de las normas medioambientales y fiscales que entorpecen el funcionamiento del libre mercado. Cualquier esquema institucional y jurídico que entrañe sustituir o limitar el desempeño individual es considerado como una afectación a la libertad y el progreso.

Como forma de gobierno, el neoliberalismo se basa en valores empresariales como la competencia, el interés, la descentralización, la deslocalización, el fortalecimiento del poder individual y las limitaciones a los poderes centrales. Se estima que las instituciones estatales deben funcionar bajo los parámetros de competencia, eficiencia y eficacia de las empresas privadas, y que en lugar de promover el bien común o el desarrollo de la sociedad

351 Steger, Manfred B. y Roy, Ravi K., Neoliberalismo. Una breve introducción, Madrid, Alianza Editorial, 2011, pp. 29-34.

352 Varoufakis, Yanis, El minotauro global. Estados Unidos, Europa y el futuro de la economía mundial, México, Ediciones Culturales Paidós, 2015, p. 29. 
Este libro forma parte del acervo de la Biblioteca Jurídica Virtual del Instituto de Investigaciones Jurídicas de la UNAM

civil y de la justicia social, el gobierno debe impulsar la transformación de la mentalidad burocrática y sustituirla por visiones empresariales para garantizar el libre mercado. Los empleados del gobierno no se deben ver a sí mismos como garantes del bien público, sino como participantes responsables del funcionamiento del mercado.

En cuanto a las medidas económicas del neoliberalismo, éstas se caracterizan por desregular la economía, liberalizar el comercio y la industria y privatizar las empresas estatales. Específicamente, sus tendencias económicas se caracterizan por lo siguiente: desmantelamiento de las regulaciones que existían sobre diferentes actividades, destacando, entre otras, a las financieras, las que asumen un rol fundamental en la orientación de las actividades productivas; debilitamiento de la posición negociadora del trabajo mediante distintas desregulaciones y acotamientos de las relaciones obreropatronales; estrechamiento financiero y reglamentario en la prestación de servicios de bienestar social; reorganización de las actividades productivas para reducir costos, incluyendo la introducción de innovaciones tecnológicas, la reducción de las plantillas laborales y la relocalización geográfica de porciones importantes de los procesos productivos o de actividades completas; reducción del déficit fiscal, dejando el peso para lograrlo sobre el gasto del gobierno, como consecuencia de las acciones de desgravación impositiva; privatización de empresas y servicios públicos al igual que la subcontratación de actividades como parte de la provisión de servicios públicos; política macroeconómica centrada en la estabilidad de precios y abandono de la política fiscal macroeconómica que anteriormente en el modelo keynesiano servía para redistribuir la riqueza, y liberalización de los flujos de comercio y capital entre países.

La teoría crítica del neoliberalismo señala que en él, como en otras relaciones de dominación que históricamente han existido, los vínculos sociales están gobernados por la violencia de clase. El neoliberalismo no sólo es una estructura económica, sino un esquema integral geopolítico que conjuga la violencia política, militar, ideológica, jurídica y estatal, para que las transformaciones estructurales que promueve pongan a las anteriores variables de su lado con el propósito de modificar, en beneficio de las clases dominantes, los elementos que conforman la convivencia social y la nueva forma de dominación política de carácter planetario pero con anclajes nacionales. ${ }^{353}$

353 Harvey, David, Breve historia del neoliberalismo, op. cit.; mismo autor, El nuevo imperialismo, op. cit.; mismo autor, El enigma del capital y la crisis del capitalismo, op. cit.; mismo autor, Seventeen Contradictions and the End of Capitalism, op. cit. 
Este libro forma parte del acervo de la Biblioteca Jurídica Virtual del Instituto de Investigaciones Jurídicas de la UNAM

\section{Tal como dice Ludolfo Paramio, el modelo neoliberal}

...se ha caracterizado por promover el recorte de impuestos, la reducción de los servicios públicos, el acoso a los sindicatos, y a lo que representan, y por impulsar la ilusión de que la prosperidad de todos depende de que los más ricos aumenten sus ingresos, alejándose cada vez más del ingreso medio, y del acceso a través del mercado a los servicios que en el modelo socialdemócrata de sociedad constituyen servicios públicos universales. La desigualdad como principio de progreso social sustituye a la visión de una sociedad cohesionada, con buena calidad de vida para todos y capaz de competir económicamente por la inversión en educación, sanidad e infraestructura. ${ }^{354}$

Las consecuencias del modelo neoliberal se expresaron en la crisis financiera global de 2008. Según Kenneth Rogoff, la desigualdad en la distribución del ingreso, la riqueza y las oportunidades en el mundo, es mayor con el neoliberalismo que la que prevaleció en cualquier año del siglo XX, y en Europa, Asia y América las

...corporaciones engordan con el dinero que viene de sus esfuerzos para lograr mayor eficiencia, pues ello les reditúa mayores ganancias. Sin embargo, la participación de los salarios dentro del total del ingreso ha estado cayendo como resultado de los altos niveles de desempleo, de las menores horas trabajadas a la semana y de los salarios estancados... la desigualdad en la distribución del ingreso es lo que más amenaza a la estabilidad social en todo el mundo. ${ }^{355}$

Ejemplo de las desigualdades crecientes es China, en donde 250 mil familias millonarias, que representan el $0.4 \%$ de la población de ese país, controlan el 70\% de la riqueza del mismo.

Frente a las crisis que provoca el modelo neoliberal, la izquierda partidista institucionalizada en el mundo no ha protestado por la profunda desigualdad existente aún en los países más desarrollados, ni ha provocado amplias movilizaciones sociales, ni ha demandado cambios profundos en las instituciones financieras mundiales o nacionales. ${ }^{356}$ La izquierda partidista con el apoyo de la derecha le ha apostado a los programas de ajuste impulsados por el Fondo Monetario Internacional y los bancos centrales

354 Paramio, Ludolfo, La socialdemocracia, Madrid, Catarata, 2009, pp. 52 y 53.

355 Rogoff, Kenneth, "The Inequality Wildcard", Project Syndicate, Praga, 4 de febrero de 2011.

356 Laclau, Ernesto, Debates y combates. Por un nuevo horizonte de la política, Buenos Aires, Fondo de Cultura Económica de Argentina, 2011, pp. 59 y ss. 
Este libro forma parte del acervo de la Biblioteca Jurídica Virtual del Instituto de Investigaciones Jurídicas de la UNAM

más importantes del planeta. Los programas de ajuste reducen el gasto público y proponen el principio de estabilidad presupuestaria para evitar los déficits públicos. La austeridad socaba el crecimiento y empeora la situación fiscal de los gobiernos, lo que termina incrementando los niveles de pobreza y desigualdad.

A pesar de los fracasos del modelo neoliberal y porque los más ricos del mundo controlan la política y el orden jurídico en su beneficio, el modelo neoliberal sigue insistiendo en sus dogmas. En el campo financiero se sostiene bajar el gasto público, vender las empresas públicas que aún quedan en manos del Estado, continuar desregulando la actividad de los particulares y reducir aún más la deuda pública. En el campo de la moneda y crédito se mantiene seguir liberalizando los mercados financieros para que una vez recuperada la confianza y sin mayor intervención del Estado, logren eventualmente canalizar recursos a las actividades productivas. ${ }^{357}$ En el mercado de trabajo se quiere eliminar todos los aspectos que entrañan para las empresas mayor costo de contratación y despido de la mano de obra. En materia de prestaciones y medidas de carácter social se busca reducirlas al mínimo social.

Esos objetivos sólo se pueden lograr teniendo los instrumentos necesarios para ello. Esas herramientas imprescindibles son el orden jurídico y la estructura estatal. El modelo neoliberal, desde luego, va más allá de la economía y se expresa en la política y en el derecho. Los poderosos del mundo requieren de sistemas jurídicos y estaduales compatibles con el modelo neoliberal. ${ }^{358}$ Por tanto, existe un modelo jurídico y estadual del neoliberalismo que proporciona servicio a los dogmas neoliberales para que los más ricos, el 1\% de la población mundial, se siga distanciando social, económica, política y jurídicamente, del 99\% de la población más pobre del planeta.

\section{EL MODELO JURÍDICO DE LA GLOBALIZACIÓN NEOLIBERAL}

A la par de los procesos de globalización económica neoliberal se desarrollan y despliegan como instrumento de esos procesos y a su servicio, complejas estructuras jurídicas que se pueden caracterizar por su opacidad e ilegiti-

357 Rivero, Oswaldo de, El mito del desarrollo y la crisis de la civilización, México, Fondo de Cultura Económica, 2014, pp. 70-77.

358 Kaplan, Marcos, Estado y globalización, México, Instituto de Investigaciones Jurídicas, UNAM, 2008. 
Este libro forma parte del acervo de la Biblioteca Jurídica Virtual del Instituto de Investigaciones Jurídicas de la UNAM

midad. ${ }^{359}$ Opacidad porque las sociedades nacionales desconocen cómo se construyen esos sistemas normativos, que se realizan no en su beneficio, sino en el de los grandes intereses trasnacionales. Ilegitimidad porque los ciudadanos de los respectivos países no votan esas estructuras normativas, ni directa ni indirectamente, aunque al final se les imponen y afectan sus vidas.

Las estructuras jurídicas de la globalización se crean y se mantienen en forma de red — las redes jurídicas de la globalización neoliberal-. ${ }^{360}$ Son redes jurídicas porque no se diseñan de manera jerárquica como en el derecho nacional a partir de la Constitución, sino que van construyéndose en forma de red, sin el respaldo de una única autoridad mundial o nacional; en su integración participan autoridades y agentes privados trasnacionales; las normas que conforman esas redes no tienen exclusivamente un origen público sino fundamentalmente privado - las grandes corporaciones -; las redes sustituyen las fuentes jurídicas tradicionales - la Constitución y la ley-, y se nutren fundamentalmente de un derecho contractual, en donde la ley del más fuerte gana más espacios. Como dice Ferrajoli, se produce un vacío del derecho público a favor de un derecho privado de carácter mundial, en el que múltiples centros de decisión jurídica trasnacional disputan, y generalmente, sobrepasan la presencia normativa del Estado-nación. ${ }^{361}$

La circunstancia de que ahora el derecho de la globalización opere en forma de red más que en la tradicional imagen de pirámide normativa, no significa que exista una sola red, hay varias redes operando simultáneamente. Las redes poseen un carácter multifuncional, pues tienen capacidad para generar sus reglas de operación, sus procedimientos de resolución de conflictos, sus mecanismos para producir nuevas normas jurídicas y hasta criterios propios de legitimación. Dentro de la gran red jurídica de la globalización económica neoliberal podemos ubicar dos tipos de redes: 1) las redes jurídicas económicas transgubernamentales y 2) las redes privadas económicas de autorregulación transnacional. En el caso de las redes jurídicas transgubernamentales, los centros de producción jurídica son, por ejem-

359 Hernández Cervantes, Aleida, La producción jurídica de la globalización económica, México, UNAM-Universidad Autónoma de San Luis Potosí-Centro de Estudios Jurídicos y Sociales Mispat, 2014, pp. 203-216.

360 Teubner, Gunther, El derecho como sistema autopoiético de la sociedad global, en Gómez-Jara Díez, Carlos (ed.), Colombia, Universidad Externado de Colombia, 2005; Sousa Santos, Boaventura de, La globalización del derecho. Los nuevos caminos de la regulación y la emancipación, Bogotá, Facultad de Derecho de la Universidad de Colombia-ILSA, 2002; Faria, José Eduardo, El derecho en la economía globalizada, op. cit.

361 Ferrajoli, Luigi, "Es posible una democracia sin Estado", Razones jurídicas del pacifismo, Madrid, Trotta, 2004, p. 142. 
Este libro forma parte del acervo de la Biblioteca Jurídica Virtual del Instituto de Investigaciones Jurídicas de la UNAM

plo, el Fondo Monetario Internacional, el Banco Mundial, la Organización Mundial del Comercio, la Comisión de las Naciones Unidas para el Derecho Mercantil Internacional y el Instituto para la Unificación del Derecho Privado. En las redes privadas económicas de autorregulación trasnacional tenemos organismos privados internacionales, por ejemplo, la Cámara de Comercio Internacional, es decir, son los centros de producción jurídica para sus agremiados, y utilizan el poder, la presión o la persuasión, para que las regulaciones producidas sean adoptadas por las legislaciones nacionales.

La validez de las normas jurídicas producidas por los centros de creación trasnacional, que son parte de las redes, no es generada por las vías tradicionales que se emplean en el Estado-nación (participación de un órgano competente legislativo que sigue el procedimiento previamente establecido en normas del Estado y en donde las normas resultantes respetan el contenido de la Constitución y de otras normas superiores), sino a través de la persuasión que se respalda en criterios económicos, con el poder que detentan los grandes intereses económicos mundiales y a través de la amenaza de sanciones de tipo pecuniario o de la exclusión de los privilegios e intereses que se derivan de ser parte de la integración en la comunidad económica globalizada. Esto es, la fuerza normativa de las normas jurídicas de la globalización neoliberal viene dada por el poder que los centros de producción trasnacional poseen para que sus instrumentos jurídicos sean adoptados, observados y aplicados. ${ }^{362}$

La finalidad de las redes jurídicas de la globalización económica neoliberal es construir un marco jurídico flexible que relativamente le dé orden y estructura jurídica a las múltiples operaciones y procesos que constituyen la globalización económica. Se pretende que las redes otorguen institucionalidad y certidumbre a los procesos económicos globales que operan al margen de los derechos nacionales, incluso del tradicional derecho internacional.

En este sentido, las características jurídicas del Estado-nación se han transformado. Podemos decir que los principales elementos de las formas tradicionales de Estado-nación se desvanecen, porque instituciones trasnacionales, que a su vez son contraladas por las grandes potencias, limitan la soberanía interna de las naciones. El Fondo Monetario Internacional, que tiene como fin suministrar recomendaciones técnicas, dar orientaciones económicas y préstamos financieros a las economías en desarrollo, condiciona a los países en vías de desarrollo, el acceso a los préstamos económicos, y requiere a los

362 Engle, Merry Sally et al., Pluralismo jurídico, Bogotá, Colombia, Siglo del Hombre editores-Universidad de los Andes-Pontificia Universidad Javeriana, 2007. 
Este libro forma parte del acervo de la Biblioteca Jurídica Virtual del Instituto de Investigaciones Jurídicas de la UNAM

gobiernos que restrinjan la expansión del crédito, reduzcan el gasto público, disminuyan los salarios y los empleos en el sector público, estabilicen el tipo de cambio y limiten a sus mínimos los programas sociales. El Banco Mundial suele exigir a los países en vías de desarrollo, a cambio de apoyos financieros, programas de ajuste estructural y sectorial, el cumplimiento de normas de austeridad monetaria y fiscal, la mayor apertura de la economía al sector privado, la remoción completa de las prestaciones domésticas contra las fuerzas de la economía internacional y exigencias de buen gobierno asociado al respeto de los derechos humanos, democracia y rendición de cuentas de la administración pública. ${ }^{363}$

La condicionalidad del Banco Mundial y del Fondo Monetario Internacional a los países en vías de desarrollo implica una pérdida de soberanía evidente en el ámbito económico y financiero de las naciones, aunque no sólo en esos espacios. La condicionalidad trasciende también en la seguridad nacional, la seguridad interna y en la política interna, tal como ocurre con las reformas estructurales aprobadas en los países por sus Congresos locales por recomendación de organismos trasnacionales, como la Organización para la Cooperación y el Desarrollo Económicos (OCDE). ${ }^{364}$ Es importante destacar que detrás de la condicionalidad de los organismos trasnacionales están las grandes potencias que controlan a esos organismos trasnacionales. Es decir, la globalización desde arriba, es un ejercicio de geopolítica en beneficio de los poderes económicos, políticos y militares más importantes del planeta.

Un elemento fundamental del Estado-nación, el más importante sin duda desde Bodin, es la soberanía. Como lo señala Gustavo Zagrebelsky, la soberanía en los nuevos Estados trasnacionales se ha transformado. En el Estado-nación del siglo XIX y buena parte del siglo XX, la soberanía interna indicaba la inconmensurabilidad del Estado frente a cualesquiera otros sujetos, y por tanto, la imposibilidad de entrar en relaciones jurídicas con ellos, pues frente al Estado soberano no podían existir más que relaciones de sujeción. Desde una perspectiva externa, los Estados se presentaban como fortalezas cerradas protegidas por el principio de la no injerencia. ${ }^{365}$

En el Estado contemporáneo del neoliberalismo ambas dimensiones de la soberanía se han modificado. Internamente, el pluralismo jurídico, el fortalecimiento de poderes fácticos nacionales que disputan con el Estado el

363 Hernández Cervantes, Aleida, La producción jurídica de la globalización económica, op. cit., p. 182.

364 En México reformas estructurales, como la educativa o la energética, se aprobaron por recomendación de organismos como la OCDE, el FMI o el Banco Mundial. Cárdenas Gracia, Jaime, Crítica a la reforma constitucional energética de 2013, México, UNAM, 2014.

365 ZAGREBELSKY, Gustavo, El derecho dúctil. Ley, derechos, justicia, op. cit., pp. 10 y 11. 
Este libro forma parte del acervo de la Biblioteca Jurídica Virtual del Instituto de Investigaciones Jurídicas de la UNAM

poder y la creciente integración de los Estados a entidades supranacionales, propician que la soberanía desde su dimensión interna no le brinde al Estado la prevalencia que tuvo anteriormente. Externamente, la globalización y el desarrollo de poderes fácticos e institucionales internacionales han acabado con el principio de no injerencia nacional. Hoy en día, las grandes corporaciones económicas y las instituciones internacionales condicionan la vida interna de los países y parecen aniquilar el principio de autodeterminación nacional.

A diferencia de lo que opina Zagreblesky, el futuro no es promisorio porque no basta con construir un nuevo Estado constitucional con garantías de legitimidad democrática y de protección de los derechos humanos al interior de los Estados 366 - aunque es importante hacerlo porque es una parte del problema-, sino que es necesario someter a derecho y a controles democráticos a los poderes fácticos trasnacionales, y dotar de legitimidad democrática a las instancias supranacionales. ${ }^{367}$ Hoy por hoy, esa transformación se ve remota porque la institucionalidad internacional depende en gran medida de la economía mundial y de quien la dirige en su beneficio.

En el nivel interno de los Estados, los cambios jurídicos de la globalización neoliberal se perciben claramente. Gerardo Pisarello advierte la aparición de procesos deconstituyentes en las naciones que falsean el sentido garantista - maximizador de los derechos humanos y de la democraciade los marcos constitucionales y, también, destaca el desarrollo de un constitucionalismo liberal oligárquico que responde a la vigencia de las redes jurídicas internacionales y a la importancia que en ellas tiene la nueva lex mercatoria vinculada a los intereses de las grandes empresas trasnacionales, a los organismos financieros y comerciales internacionales y, por supuesto, a las grandes potencias que están detrás de todos esos procesos. Al interior de los Estados, los órganos de defensa de la Constitución - ejecutivos, parlamentos, tribunales constitucionales - han asistido impotentes, cuando no han alentado, el vaciamiento normativo nacional, el que es promovido desde instancias estatales y supraestatales. Las Constituciones y los marcos jurídicos nacionales se vuelven flexibles frente a las presiones antisociales de la globalización, y rígidas frente a las exigencias democratizadoras provenientes de las sociedades locales, principalmente de los sectores más desfavorecidos. ${ }^{368}$

366 Ibidem, pp. 12 y ss.

367 Así lo propone Stiglitz, véase Stiglitz, Joseph E., El malestar en la globalización, Madrid, Santillana, 2002, pp. 269 y ss.

368 Pisarello, Gerardo, Procesos constituyentes. Caminos para la ruptura democrática, Madrid, Trotta, 2014, pp. 16 y 17. 
Este libro forma parte del acervo de la Biblioteca Jurídica Virtual del Instituto de Investigaciones Jurídicas de la UNAM

Las características del derecho interno paulatinamente van modificándose. El Estado ya no concentra el monopolio de la producción jurídica, sino que lo comparte con las instancias supranacionales, tanto públicas como privadas. La lex mercatoria implica la existencia de un ordenamiento espontáneo de los negocios del comercio internacional al margen del Estado. Se comienza a transformar el esquema piramidal y jerárquico de las normas del derecho interno y se sustituye por la pluralidad de redes normativas internacionales. En el derecho internacional con consecuencias jurídicas internas se manifiesta un soft law que carece de sanciones explícitas, por ejemplo, la pluralidad creciente en el derecho interno de lineamientos, directrices, códigos de conducta y normas técnicas. Vinculado a lo anterior se presenta en los Estados-nación el vaciamiento normativo del derecho público y el avance de un derecho privado orientado por los criterios de la globalización. Con lo anterior, el ordenamiento jurídico interno pierde certeza jurídica al competir con las redes jurídicas de la globalización, y principios, como el de la supremacía, se diluyen; se trastocan las viejas virtudes de generalidad y abstracción de las normas, pues el derecho de la globalización neoliberal es casuístico y fugaz, y las características de unidad y coherencia del ordenamiento, por la fuerza de las redes jurídicas de la globalización, obligan a que el sistema jurídico se fragmente, aumenten las lagunas y las antinomias jurídicas.

Desde el punto de vista de la aplicación del derecho interno globalizado, son instancias de arbitraje internacional y tribunales foráneos o supranacionales los que lo aplican, principalmente el derecho referido al comercio, a las inversiones, el que afecta a los sectores y ámbitos de las otrora áreas estratégicas del Estado ${ }^{369}$ o el relacionado con los derechos humanos. De esta suerte, la producción jurídica más importante es externa y la interpretación y aplicación del derecho interno globalizado corresponde a instancias jurisdiccionales foráneas o supranacionales.

En cuanto a los derechos económicos, sociales, culturales y ambientales, como dice José Eduardo Faria, cuanto más veloz es la integración de los mercados en un sistema mundo o en una economía-mundo, más se reduce la capacidad de coordinación macroeconómica de los Estados-nación, pues mediante las recomendaciones de los organismos financieros internacionales llega a impedírseles establecer políticas keynesianas de altas tasas de gasto

369 En México este proceso claramente se manifiesta en la reciente reforma energética, en donde serán instancias de arbitraje y tribunales extranjeros los que resuelvan las disputas entre el gobierno mexicano y las empresas trasnacionales energéticas. Cárdenas Gracia, Jaime, Crítica a la reforma constitucional energética de 2013, op. cit. 
Este libro forma parte del acervo de la Biblioteca Jurídica Virtual del Instituto de Investigaciones Jurídicas de la UNAM

público para sustentar el empleo o el crecimiento económico. ${ }^{370}$ De esta manera, las posibilidades del Estado se reducen para garantizar o contribuir a garantizar los derechos sociales. El modelo jurídico neoliberal de la globalización se caracteriza por la reducción sustancial en la satisfacción de los derechos sociales. En este modelo, los ciudadanos del Estado nación tienen menos acceso al empleo, a la salud, a la educación, a la vivienda y otros derechos sociales que en el viejo modelo del Estado del bienestar.

El derecho de la globalización, como dijimos líneas más arriba, es un derecho opaco e ilegítimo. La opacidad es evidente porque las normas jurídicas del soft law son producidas por instancias supranacionales gubernamentales y no gubernamentales, sin la participación de la sociedad, sin rendición de cuentas. Los procedimientos de generación de ese derecho se toman por unos cuantos funcionarios y empresarios - la tecnocracia de la globalización - y las sociedades nacionales desconocen las razones, motivos o argumentos que esgrimen esas personas para producir ese derecho, a quién beneficia y por qué no beneficia o se produce bajo criterios alternativos. El proceso legislativo de creación del derecho de la globalización se realiza sin luz ni taquígrafos, sin debates parlamentarios en las instituciones planetarias, y sin que los sectores sociales involucrados o afectados por esas normas, puedan exponer sus puntos de vista en esos procedimientos. Es ilegítimo el derecho de la globalización neoliberal porque se trata de un derecho conformado por personas que no han sido electas por el pueblo, que no le rinden cuentas al pueblo, que no pueden ser removidas de sus funciones por el pueblo, y que el derecho producido no responde a los intereses del pueblo ni a los derechos fundamentales, sino a los intereses y deseos de las grandes corporaciones internacionales y de los poderes políticos y económicos que están detrás de ellas. El derecho de la globalización no se somete, en muchos casos, a la aprobación de los parlamentos de los Estados-nación, y mucho menos al referéndum ciudadano. Es, además, un derecho que no puede ser derogado o abrogado por los ciudadanos de los Estados-nación.

\section{LAS GARACTERÍSTICAS NEOLIBERALES DEL ESTADO, CON REFERENCIA A MÉXICO}

Después de la Segunda Guerra Mundial se pensó que tanto el comunismo como el capitalismo habían fracasado y que era necesario construir un nuevo tipo de Estado que combinara el mercado con la planificación económica

370 Faria, José Eduardo, El derecho en la economía globalizada, Madrid, Trotta, 2001, p. 30. 
Este libro forma parte del acervo de la Biblioteca Jurídica Virtual del Instituto de Investigaciones Jurídicas de la UNAM

para garantizar la paz, la integración, el bienestar y la estabilidad. ${ }^{371}$ Esta pretensión teórica fue exitosa en la práctica, y durante las décadas de los años cincuenta y sesenta del siglo pasado, muchos países del capitalismo avanzado e incluso en desarrollo, como México, crecieron a altas tasas y distribuyeron en diversos grados y niveles la riqueza entre sus poblaciones.

En la década de los años setenta del siglo pasado, la caída de los ingresos tributarios en muchos países y el aumento de los gastos sociales provocaron lo que se denominó la crisis fiscal del Estado. Este hecho económico vinculado con otros, como la crisis del petróleo de 1973, pusieron en duda la viabilidad de las políticas keynesianas. Ante el estancamiento de la economía capitalista y la necesidad de salir de la crisis, se propusieron distintas medidas económicas y políticas. Podemos decir que desde la socialdemocracia se insistió en estrategias corporativistas para intensificar la presencia estatal y la regulación económica en el control de precios y salarios en aras de mantener el esquema del Estado del bienestar. Sin embargo, esta estrategia no prevaleció porque implicaba una amenaza política a las élites económicas y a las clases dominantes, y por motivos estrictamente ideológicos, lo que hoy conocemos como proyecto neoliberal, fue escogido para restaurar el poder de esas clases que habían perdido terreno en el Estado del bienestar y con la crisis fiscal del Estado, ${ }^{372}$ y que con el neoliberalismo, han restaurado inmensamente su poder económico en las sociedades a costa de los derechos de las amplísimas mayorías sociales, tanto en países desarrollados como en los que se encuentran en vías de desarrollo.

Los fundamentos teóricos del modelo neoliberal globalizador tienen sus antecedentes inmediatos en la obra económica de Friedrich von Hayek y en la creación de la asociación Mont Pelerin Society que aglutinaba a personajes como Ludwig von Mises, Milton Friedman y Karl Popper. En sus orígenes, la asociación Mont Pelerin Society promovía una fuerte defensa de la propiedad privada y del mercado, y obviamente, se oponía a las teorías económicas que defendían el intervencionismo estatal. El grupo Mont Pelerin recabó apoyos financieros y políticos en Estados Unidos y en los países europeos, y paulatinamente, los recibieron y lograron consolidar su influencia cuando políticos como Margaret Thatcher y Ronald Reagan, accedieron al poder en Gran Bretaña y los Estados Unidos. El siguiente paso consistió en

371 Dahl, Robert y Lindblom, Charles, Politics, Economy and Walfare. Planning and PoliticoEconomic Systems Resolved into Basic Social Processes, Nueva York, Harper, 1953.

372 Duménil, Gerard y Lévy, Dominique, "Neoliberal Dynamics. Towards A New Phase?, en K. van der Pijl, L'Assassin, y Wigand, Duncan (eds.), Global Regulation. Managing Crises after de Imperial Turn, Nueva York, Palgrave MacMillan, 2004, pp. 41-63. 
Este libro forma parte del acervo de la Biblioteca Jurídica Virtual del Instituto de Investigaciones Jurídicas de la UNAM

extender este credo al resto del planeta, lo que lograron a través de organismos financieros internacionales como el Banco Mundial y el Fondo Monetario Internacional, y por medio de las presiones de la Reserva Federal de los Estados Unidos en países como México. David Harvey explica la naturaleza de las presiones y los chantajes. Describe que entre los años de 1982-1984, tanto el Departamento del Tesoro de los Estados Unidos, como el Fondo Monetario Internacional, accedieron a reestructurar el endeudamiento de nuestro país a cambio de que nuestro gobierno se comprometiera a realizar reformas institucionales consecuentes con el modelo neoliberal, recortara el gasto público y emprendiera la privatización de sus empresas públicas. 373

Por eso estamos obligados a desmentir los presupuestos de la teoría económica, política y jurídica neoliberal. Esos presupuestos sostienen que el neoliberalismo globalizador promueve la libertad de las personas. La noción es errónea porque no distingue que en las sociedades complejas la libertad no es concepto diáfano y unívoco. Podemos mencionar que existen, tal como lo hizo Polanyi, dos tipos de libertad. ${ }^{374}$ El primer género es la libertad que promueve el neoliberalismo globalizador: una libertad para explotar a los demás; la libertad para obtener ganancias desmesuradas sin retribuir a las comunidades; la libertad de impedir que las innovaciones tecnológicas sean utilizadas con una finalidad pública; la libertad para beneficiarse de las calamidades públicas, y la libertad para obtener ventajas del daño que causamos o de la apropiación indebida de la riqueza de los otros. El segundo tipo son las libertades que son compatibles con el Estado de derecho y la democracia, como la libertad de mercado, de conciencia, de expresión, de reunión, de asociación, y la libertad de elegir nuestro propio trabajo. Estas últimas son las que debemos potenciar, pero a la par, debemos evitar que sean manipuladas en beneficio de los que promueven el primer tipo de libertades como lo hace el neoliberalismo.

Entre los supuestos teóricos del Estado neoliberal se han mencionado, entre otros, los siguientes: protege la propiedad privada, mantiene el imperio de la ley y fortalece el libre mercado y el libre comercio; son divisa la inviolabilidad de los contratos y los derechos a la libertad de expresión y de acción; la empresa privada y la iniciativa empresarial son las llaves de la innovación y de la creación de la riqueza; los derechos de propiedad intelectual son garantizados para estimular los cambios tecnológicos;

373 Harvey, David, Breve historia del neoliberalismo, op. cit., p. 36.

374 Polanyi, Karl, The Great Transformation, Boston, Beacon Press, 1954. 
Este libro forma parte del acervo de la Biblioteca Jurídica Virtual del Instituto de Investigaciones Jurídicas de la UNAM

se asegura la eliminación de la pobreza a través de los mercados libres y del libre comercio; se dice que la ausencia de protección a los derechos de propiedad constituye una barrera que impide el desarrollo económico y el bienestar humano; se busca prohibir los bienes comunes para que no sean sobreexplotados irresponsablemente por cualquiera; se mantiene que el Estado no debe controlar ni explotar ningún sector de la economía, porque ello empobrece a las sociedades y limita la competencia económica; se afirma que la privatización, la desregulación y la competencia eliminan los trámites burocráticos, incrementan la eficiencia, la productividad y se evita la corrupción; se argumenta que se defiende la libertad personal, que es la base del desarrollo personal y de la economía; se asume que la competencia internacional mejora la eficiencia, la competitividad, reduce los precios y controla las tendencias inflacionarias; se sostiene que los tratados y acuerdos comerciales como el TLCAN son cruciales para el avance del proyecto neoliberal global, y se prefiere una democracia de élites y de expertos a una democracia de mayorías o popular para no poner en riesgo las libertades y los derechos de las minorías. ${ }^{375}$

Sin embargo, los teóricos del neoliberalismo no suelen exponer las contradicciones del modelo neoliberal globalizador. Entre éstas se deben destacar las siguientes:

1) La competencia económica acaba muchas veces en monopolios y oligopolios, pues las empresas más fuertes expulsan a las más débiles del mercado.

2) La teoría económica neoliberal es incapaz de explicar la existencia de los monopolios naturales, como los que existen en el ámbito energético, principalmente en la electricidad.

3) El modelo neoliberal se desentiende de los fallos del mercado, es decir, de las externalidades (quién paga la contaminación o la afectación al medio ambiente o a la salud que propicia la actividad económica de las empresas).

4) El modelo neoliberal desconoce las condiciones asimétricas de los diversos agentes que actúan en el mercado nacional y mundial, dado que, por ejemplo, no todos poseen el mismo nivel de información o las mismas capacidades tecnológicas.

5) El modelo neoliberal no se hace cargo de la existencia de determinados derechos de propiedad que, como la propiedad intelectual, propician la búsqueda de rentas y no la competencia económica.

${ }^{375}$ Harvey, David, Breve historia del neoliberalismo, op. cit., pp. 73-76. 
Este libro forma parte del acervo de la Biblioteca Jurídica Virtual del Instituto de Investigaciones Jurídicas de la UNAM

6) El modelo neoliberal omite describir que en muchas ocasiones el desarrollo científico y tecnológico están desconectados del mercado y las innovaciones que se producen suelen no tener demanda.

7) El modelo neoliberal no da cuenta de las consecuencias especulativas que propicia la gran acumulación del capital financiero.

8) El modelo neoliberal tampoco atiende los elementos disolventes del propio modelo; es decir, quién se hace cargo de los menos aventajados de las sociedades y de los países.

9) El modelo neoliberal elude los elementos autoritarios que prohíja, tales como la democracia electoral elitista o de expertos que promueve, lo que motiva amplios descontentos sociales por la ausencia de canales de participación efectivos.

10) El modelo neoliberal no afronta la ilegitimidad y opacidad que sostiene a los organismos financieros internacionales y a las corporaciones trasnacionales que crean y aplican el soft law y la lex mercatoria. ${ }^{376}$

En síntesis, el Estado neoliberal globalizador mercantiliza todos los derechos humanos y los bienes comunes en beneficio de las grandes corporaciones trasnacionales. El Estado neoliberal globalizador se mantiene autoritariamente con enormes déficits de legitimidad democrática y de transparencia, ${ }^{377}$ en tanto que no se promueve la participación y la deliberación pública de los asuntos colectivos; no respeta el medio ambiente ni las culturas ancestrales, pues expolia y saquea intensiva y extensivamente los recursos naturales del planeta en beneficio de unos cuantos; es el principal promotor de la pobreza y la desigualdad mundial. Es un Estado diseñado desde los intereses de las clases dominantes, y por tanto, alienta Estados racistas, clasistas y profundamente injustos que favorecen la represión policial de los débiles, la construcción de relaciones interpersonales basadas en el miedo, en el estereotipo, en la distancia física y en la sospecha. ${ }^{378}$

Las características neoliberales del nuevo Estado se integran, desde nuestro punto de vista, por los siguientes elementos, a los que en otros trabajos he aludido:379 1) poderes fácticos nacionales y trasnacionales sin lími-

376 Ibidem, pp. 76-79.

377 Benz, Arthur, El Estado moderno. Fundamentos de su análisis politológico, Madrid, Centro de Estudios Políticos y Constitucionales, 2010.

378 Sousa Santos, Boaventura de, Refundación del Estado en América Latina. Perspectivas desde una epistemología del Sur, México-Guatemala-Buenos Aires, Universidad de los Andes-Siglo del Hombre Editores-Siglo XXI Editores, 2010, pp. 161 y 162.

379 Cárdenas Gracia, Jaime, "La construcción del Estado constitucional en México", en Molina Piñeiro, Luis et al., ¿̨Constitucionalizar democratiza!, México, Porrúa-UNAM, 201 1, pp. 82-105; mismo autor, El modelo jurídico del neoliberalismo, México, UNAM, 2015 (en prensa). 
Este libro forma parte del acervo de la Biblioteca Jurídica Virtual del Instituto de Investigaciones Jurídicas de la UNAM

tes y controles jurídicos suficientes; 2) derechos fundamentales sin garantías plenas de realización, principalmente respecto a los derechos económicos, sociales, culturales y ambientales; 3) débil democratización, transparencia, rendición de cuentas, eficiencia y eficacia de las instituciones del Estado y de las trasnacionales; 4) supremacía de los tratados internacionales, principalmente los relacionados con el comercio, las inversiones y la propiedad, por encima de las Constituciones nacionales; 5) mecanismos débiles de derecho procesal constitucional para no proteger con suficiencia los derechos fundamentales de carácter social ni los derechos colectivos; 6) instrumentos anticorrupción compatibles con los intereses de las grandes corporaciones trasnacionales; 7) reducción de la democracia participativa, deliberativa y comunitaria, y con ello, impulso de una democracia electoral manipuladora de los derechos políticos de los ciudadanos; 8) entrega del patrimonio de las naciones - sus recursos naturales - y de su explotación a los intereses foráneos; 9) inadecuada defensa de la soberanía nacional, y 10) implantación del modelo económico neoliberal globalizador para someter al derecho y al Estado nacional en su provecho.

En lo tocante al primer elemento, los poderes fácticos nacionales, pero sobre todo los trasnacionales, se desbocan en el Estado neoliberal, quedan sin control jurídico y democrático alguno. Grandes corporaciones de las telecomunicaciones, financieras y bancarias, de la información, de la energía, de carácter militar, de los alimentos, actúan por encima del poder y de las instituciones de los Estados nacionales - en especial de los más débiles - con el respaldo de las grandes potencias económicas y militares del mundo. Los factores reales de poder, tanto nacionales como internacionales, colonizan y determinar el funcionamiento de las instituciones nacionales y supranacionales. El orden jurídico resultante se pone al servicio de esos intereses por encima de los derechos de las personas y las colectividades.

Las soluciones a las amenazas que representan los poderes fácticos nacionales y trasnacionales contra los derechos de las personas y de los grupos debieran pasar, entre otras, por las siguientes medidas: 1) preservar al Estado y fortalecerlo mediante la integración de la democracia ciudadana, ello implica democratizar y transparentar sus instituciones e incorporar medios de democracia participativa, deliberativa y comunitaria; ${ }^{380}$ 2) aprobar una estricta legislación antimonopolios; 3) determinar que los poderes fácticos

380 Algunos abundan en formas de globalización económica y social desde abajo. Alba Vega, Carlos et al., La globalización desde abajo. La otra economía mundial, México, Fondo de Cultura Económica-El Colegio de México, 2015. 
Este libro forma parte del acervo de la Biblioteca Jurídica Virtual del Instituto de Investigaciones Jurídicas de la UNAM

son sujetos obligados de las normas de transparencia y acceso a la información; 4) obligar a que los poderes fácticos tengan una vida interna democrática (partidos, sindicatos, organizaciones empresariales nacionales y trasnacionales, iglesias, etcétera); 5) impedir cualquier privilegio fiscal injustificado o de otro tipo que favorezca a los poderes fácticos; 6) reformar las instituciones internacionales a fin de abrirlas y democratizarlas; 7) reestructurar el sistema financiero internacional para transparentarlo y hacerlo más justo; 8) extraer del ámbito del comercio y la mercantilización recursos como la salud, la educación, la cultura, el medio ambiente, etcétera; 9) mundializar el constitucionalismo y las estructuras constitucionales de control del poder, a fin de que las relaciones económicas y otras, producto de la globalización, no queden al margen del derecho y del control ciudadano, y 10) promover un contrato global para la satisfacción de las necesidades básicas, dirigido a suprimir las ilegítimas desigualdades socioeconómicas entre clases, géneros, etnias, regiones y naciones, etcétera.

Sin embargo, los Estados nacionales son incapaces de hacer frente a la influencia de los poderes fácticos nacionales y trasnacionales. Los sistemas políticos y jurídicos de los Estados nacionales y de los organismos supranacionales están dominados por ellos y son puestos a su servicio. A nivel interno, moldean a su antojo la información a través de los medios de comunicación electrónica que ellos controlan; promueven el financiamiento privado en las campañas para supeditar los intereses generales al interés de los dueños del capital; evitan que fórmulas de democracia radical se implanten en las instituciones; los bancos centrales vigilan que las variables macroeconómicas no pongan en riesgo las ventajas derivadas del modelo; estimulan mediante el cabildeo que los legisladores impulsen las políticas públicas que a ellos les interesan, y utilizan el poder de los bancos internacionales y de los organismos financieros internacionales para respaldar el modelo que han impuesto. A nivel internacional, el escaso desarrollo del derecho internacional y la debilidad de las instituciones supranacionales, que son sostenidas económicamente por las grandes potencias, propicia que el derecho internacional que importa no sea el de los derechos humanos - mucho menos el vinculado a los derechos económicos, sociales, culturales y ambientalessino el derecho internacional del libre comercio, de la inversión, de las telecomunicaciones y de la defensa de la propiedad intelectual.

El segundo elemento del Estado neoliberal está vinculado a la existencia de profusos catálogos de derechos en las Constituciones y en los tratados que no vienen acompañados de garantías de realización, principalmente cuando se trata de proteger, estimular y garantizar los derechos económicos, 
Este libro forma parte del acervo de la Biblioteca Jurídica Virtual del Instituto de Investigaciones Jurídicas de la UNAM

sociales, culturales y ambientales. El Estado neoliberal tiene como divisa el desmantelamiento del Estado del bienestar y no dota para esos derechos fundamentales de las garantías sustantivas y procesales para hacerlos efectivos. ${ }^{381}$ Los mecanismos constitucionales, legales, administrativos y presupuestales para que los derechos sean exigibles son indispensables. ${ }^{382}$ No basta que los tratados sobre derechos humanos tengan la misma jerarquía de los principios constitucionales, es necesario que todas las autoridades, de los distintos niveles de gobierno, se responsabilicen en el ámbito de su competencia por su cumplimiento, y como ya se mencionó, que existan las garantías procesales e institucionales que posibiliten su realización y su justiciabilidad. Roberto Gargarella describe algunos ejemplos de Tribunales Constitucionales y Cortes Supremas - en Sudáfrica, India, Colombia y Argentina - que han asumido un compromiso de efectiva realización con los derechos. ${ }^{383}$ Sin embargo, esos casos aislados desgraciadamente no están generalizados, y tanto las instituciones nacionales del Estado neoliberal como las supranacionales, colocan en los hechos, a través de sus decisiones, a los derechos económicos, sociales, culturales y ambientales en un nivel jerárquico inferior al de los derechos de libertad.

En México, la reforma constitucional en materia de derechos humanos de 2011, principalmente a los párrafos segundo y tercero del artículo lo. de la carta magna, podría abonar en el cumplimiento y exigibilidad de los derechos fundamentales, principalmente de los económicos, sociales, culturales y ambientales, siempre y cuando todas las autoridades del país efectivamente hagan interpretación conforme y pro homine de constitucionalidad y de convencionalidad. Además de aplicar los principios de universalidad, interdependencia, indivisibilidad y progresividad en la interpretación de cualquier tipo de norma jurídica y en la resolución de cualquier tipo de caso. ${ }^{384}$ Desgraciadamente, mis recomendaciones distan de verse concretadas en los hechos. La Suprema Corte de Justicia de la Nación mantiene un doble discurso, pues en la retórica judicial abunda en conceptos como bloque de

381 Abramovich, Víctor y Courtis, Christian, Los derechos sociales como derechos exigibles, Madrid, Trotta, 2002.

382 Navarro, Vicenc, Bienestar insuficiente, democracia incompleta, Barcelona, Anagrama, 2002, pp. 31-103.

383 Gargarella, Roberto, "Justicia y derechos sociales: lo que no dice el argumento democrático", Teoría y crítica del derecho constitucional, Buenos Aires, Abeledo Perrot, 2008, t. II, pp. 962-965.

384 García Ramírez, Sergio y Morales Sánchez, Julieta, La reforma constitucional sobre derechos humanos (2009-2011), México, Porrúa-UNAM, 2011 ; Carbonell, Miguel y Salazar, Pedro, La reforma constitucional de derechos humanos. Un nuevo paradigma, México, Porrúa-UNAM, 2012. 
Este libro forma parte del acervo de la Biblioteca Jurídica Virtual del Instituto de Investigaciones Jurídicas de la UNAM

constitucionalidad y parámetro de constitucionalidad, al grado que decisiones como la del caso Rosendo Radilla - resolución del expediente varios 912/2010 - le mereció recibir un reconocimiento en derechos humanos de la ONU; pero en la estructura jerarquizada y piramidal del poder judicial federal, la cara es distinta cuando los jueces y magistrados federales tienen que lidiar con el poder de las instituciones y de los poderes fácticos, ya que ahí se apela a la jurisprudencia más rancia y tradicional para declarar improcedentes y sobreseer amparos que tenían por finalidad maximizar los derechos fundamentales de las personas y de los colectivos, o que buscaban cuestionar la pertinencia constitucional y convencional de las reformas estructurales que apuntalan las características del Estado neoliberal.

Es muy difícil que el Estado neoliberal acepte innovaciones institucionales como las siguientes: elección ciudadana de los ministros de la Suprema Corte de Justicia de la Nación; acciones populares de inconstitucionalidad sin que se tenga que acreditar interés jurídico o legítimo alguno; acciones colectivas para proteger cualquier derecho colectivo o interés difuso y no, como se restringen ahora en el derecho mexicano, a unas cuantas materias; el establecimiento de mecanismos de exigibilidad y justiciabilidad plena de todos los derechos, principalmente de los derechos económicos, sociales, culturales y ambientales; la aprobación mediante referéndum de los tratados internacionales; la subordinación de las fuerzas armadas al régimen de derechos humanos, y la incorporación de la doctrina de la Drittwirkung der Grundrechte para enfrentar los excesos y arbitrariedades de los poderes fácticos nacionales y supranacionales en relación con violaciones y afectaciones a los derechos económicos, sociales y culturales. ${ }^{385}$

En materia de derechos humanos, para enfrentar los efectos más negativos del Estado neoliberal, se podría pensar en el reconocimiento de nuevos derechos humanos. David Harvey propone algunos de esos nuevos derechos: derechos a oportunidades de vida; derechos al buen gobierno o gobierno justo; derecho de los trabajadores a intervenir mediante voz y voto en las distintas etapas de la producción capitalista; el derecho a no ser criminalizado por realizar protestas sociales; derecho a un medio ambiente saludable; derecho al control colectivo de los recursos de propiedad común; derechos a las nuevas generaciones; derecho a la migración; derecho a concebir los derechos desde el entorno cultural y comunitario; derecho al mínimo vital, y derecho a la libre experimentación y al acceso a los bienes de

385 Mijangos González, Javier, "La doctrina de la Drittwirkung der Grundrechte en la jurisprudencia de la Corte Interamericana de Derechos Humanos", Teoría y realidad constitucional, Madrid, núm. 20, 2007, pp. 583-608. 
Este libro forma parte del acervo de la Biblioteca Jurídica Virtual del Instituto de Investigaciones Jurídicas de la UNAM

la ciencia y la tecnología, pero sin que ello implique someterse a procesos científicos o tecnológicos que responden a los intereses de la élite o grupo social dominante. ${ }^{386}$

El tercer elemento del Estado neoliberal consiste en promover una débil democratización, transparencia, rendición de cuentas, eficiencia y eficacia de las instituciones del Estado y trasnacionales, para que las instituciones públicas — poderes y órganos constitucionales autónomos — se pongan al servicio del gran capital y de los poderes fácticos, y ni por asomo se comprometan con los derechos fundamentales de las personas y de los colectivos. El Estado neoliberal requiere de profundas innovaciones para poner fin al divorcio entre gobernantes y gobernados porque sus niveles de ilegitimidad se acentúan aceleradamente. Por ejemplo, en la reciente reforma electoral mexicana, ${ }^{387}$ hemos advertido que el gobierno mexicano es cada vez más oligárquico porque no descansa en su origen en elecciones libres y auténticas (democráticas) ${ }^{388}$, y en cuanto a su ejercicio, porque las oligarquías contemporáneas no reconocen plenamente los derechos de la oposición en la competencia por el poder político ${ }^{389}$ ni aceptan la garantía plena y satisfactoria de los derechos económicos, sociales, culturales y ambientales.

Nuestro país no ha concluido el proceso de transición a la democracia, y por tanto, no contamos con una democracia consolidada porque las élites económicas y políticas han preferido mantener el modelo del Estado neoliberal. Las estructuras políticas y electorales que anteriormente estuvieron al servicio de un partido hegemónico y de un hiperpresidencialismo, hoy en día, están al servicio de los poderes fácticos nacionales y trasnacionales, y las elites económicas y políticas que formalmente gobiernan, reproducen la ideología y las concepciones de los intereses que sostienen el aparato institucional. Cualquier visión alternativa a la dominante de la vida política o económica carece de espacios mediáticos para expresarse. De hecho, en la titularidad de los órganos constitucionales autónomos de la República, no existe representación de los indígenas, del zapatismo, de la disidencia

386 Harvey, David, Espacios de esperanza, Madrid, Akal, 2012, pp. 284-288.

387 La reforma constitucional electoral fue publicada en el Diario Oficial de la Federación del 10 de febrero de 2014, y la electoral secundaria fue publicada en el Diario Oficial de la Federación el 23 de mayo de 2014. Fundamentalmente, la Ley General de Instituciones y Procedimientos Electorales, la Ley General de Partidos, las reformas a la Ley General del Sistema de Medios de Impugnación en materia electoral, la Ley General en Materia de Delitos Electorales y la Ley Orgánica del Poder Judicial Federal.

388 Cárdenas Gracia, Jaime, La crisis del sistema electoral mexicano. A propósito del proceso electoral de 2012, México, UNAM, 2014.

389 Bobbio, Norberto, Diccionario de Política, México, Siglo XXI, 1988, t. II, pp. 1118-1122. 
Este libro forma parte del acervo de la Biblioteca Jurídica Virtual del Instituto de Investigaciones Jurídicas de la UNAM

magisterial, de los sindicatos independientes o de cualquier otra expresión alternativa de la sociedad.

En México existe una generalizada corrupción con enormes niveles de impunidad, la que se acentuará con la inclusión de la reelección legislativa y municipal incluida en la última reforma electoral de 2013-2014. El financiamiento privado y la no autonomía de la política respecto a la esfera empresarial promoverán aún más la oligarquización de la clase gobernante. La reelección limitará la renovación de las élites y concentrará el poder en los mismos de siempre en beneficio de los intereses del Estado neoliberal. La reelección afianzará el poder de los gobernantes y de los intereses económicos que los sostienen. La reforma electoral mexicana no propuso, para contrarrestar los efectos nocivos de la reelección, instituciones como la revocación del mandato, tampoco se determinó la derogación del financiamiento privado, y permitió la reelección si el cargo susceptible de ella, recibe el beneplácito de la nomenclatura del partido correspondiente. Lo anterior significará que los que se reelijan, serán los que tengan el respaldo de la clase empresarial nacional y trasnacional y de las nomenclaturas de los partidos; los reelectos serán instrumento de los poderes fácticos. La reelección fortalecerá a la clase política que representa al status quo y será un instrumento para impedir el ingreso al poder de visiones alternativas de la política o de la economía.

Las reformas electorales y políticas que en México se han aprobado son simuladoras y compatibles con el Estado neoliberal, alientan una democracia formalmente representativa carente de asideros participativos, deliberativos y comunitarios. Por ejemplo, la última reforma no incorporó la revocación de mandato, ni el referéndum; pero tampoco la acción popular de inconstitucionalidad. Se mantuvieron los requisitos constitucionales de 2012 que dificultan a los ciudadanos el derecho a la consulta, a la iniciativa legislativa ciudadana y a las candidaturas independientes.

Las tres fuerzas políticas mayoritarias que negociaron en la opacidad la reforma electoral, buscaron eliminar, a través del umbral del 3\% de la votación válida, a las fuerzas políticas minoritarias, todo ello, plenamente aceptable para las exigencias del Estado neoliberal. Igualmente, la reforma prohibió a los partidos políticos de nueva creación, la posibilidad de coaligarse (artículo segundo transitorio de la reforma constitucional) para ahondar en la lógica de eliminación jurídica - artificial - de las fuerzas políticas minoritarias. Los cauces de representación minoritaria quedaron cancelados. Las minorías en México no tendrán representantes en el Congreso de la Unión 
Este libro forma parte del acervo de la Biblioteca Jurídica Virtual del Instituto de Investigaciones Jurídicas de la UNAM

porque una débil representación política es coherente con los postulados del Estado neoliberal.

Respecto a la organización del poder en México podemos decir que es plenamente coincidente con los fines del Estado neoliberal, que casi todas las instituciones no favorecen la participación ciudadana en ellas ni la deliberación pública de los asuntos de interés general. Se trata de instituciones que no se orientan a la protección de los derechos fundamentales de todos y están diseñadas para proteger los intereses de unos cuantos sectores. Por ejemplo, en el Ejecutivo se necesita, entre otras medidas: consolidar el servicio civil de carrera; sancionar la opacidad gubernamental con la destitución de los servidores públicos; incorporar a la sociedad civil de manera efectiva en el procesamiento y determinación de las políticas públicas; las decisiones administrativas fundamentales, tales como la aprobación de reglamentos, la definición del proyecto de presupuesto o el ejercicio del gasto público, deben abrirse a la participación y conocimiento ciudadano; es preciso derogar la proliferación de normas administrativas en materias reservadas por la Constitución a la ley; en la negociación y aprobación de tratados y acuerdos internacionales debe participar la ciudadanía con el conocimiento de los procesos respectivos y en la aprobación mediante referéndum; los tribunales administrativos deben pasar al Poder Judicial; los sistemas de seguridad nacional y pública deben quedar sujetos a los más amplios niveles de participación ciudadana y transparencia; es preciso retirar al ejército de las labores de seguridad pública; es necesario establecer un catálogo de responsabilidades al titular del Ejecutivo; es indispensable sujetar a control pleno del Legislativo y de los ciudadanos las atribuciones hacendarias, fiscales y presupuestales de la Secretaría de Hacienda y Crédito Público, y es ineludible reducir las atribuciones del Ejecutivo para comprometer la deuda pública del país.

En el legislativo son necesarias, entre otras medidas, incrementar sus atribuciones de control y de orientación política al Ejecutivo; fortalecer el papel de las comisiones de investigación sobre los asuntos sociales, políticos y económicos; regular los conflictos de interés de los legisladores y el cabildeo; implementar el servicio civil de carrera; establecer medidas estrictas de transparencia y racionalidad en el ejercicio de los recursos públicos en el Legislativo; determinar un régimen de responsabilidades y sanciones a los legisladores por incumplimiento de sus funciones; hacer de las comisiones legislativas el motor del Parlamento; fortalecer la deliberación y la transparencia en todos los ámbitos del Legislativo; modificar la organización de las Cámaras para que sus funciones de desarrollen con horizontalidad; otorgar legitimación procesal activa a los grupos parlamentarios para 
Este libro forma parte del acervo de la Biblioteca Jurídica Virtual del Instituto de Investigaciones Jurídicas de la UNAM

promover acciones de inconstitucionalidad y controversias constitucionales, y fortalecer la independencia y libertad del legislador mediante la introducción en la ley del estatuto del legislador. ${ }^{390}$

El poder clásico en los sistemas políticos y jurídicos comparados para la accountability horizontal es el Poder Judicial. Sin embargo, en México y en muchos países como el nuestro, es un poder débil política y socialmente, un poder no independiente, que no cumple su función de garantizar el acceso a la justicia y la protección judicial de miles de personas; un poder, además, deficiente, en donde la resolución de conflictos espera años para obtener una respuesta judicial que no siempre es de calidad. Lo más importante en este poder entrañaría ampliar el acceso a la justicia, la independencia del Poder Judicial, así como su eficiencia y eficacia ${ }^{391}$ para que no estuviese más al servicio de los fines del Estado neoliberal.

Entre otras reformas al poder judicial se pueden proponer las siguientes: 1) ciudadanizar al Consejo de la Judicatura Federal para abrir esa institución a la sociedad. Que el presidente del Consejo no sea el de la Suprema Corte de Justicia de la Nación para que no exista el conflicto de interés que hoy se tiene. Que en la integración del Consejo no haya mayoría judicial para que no se refuerce en su interior el nepotismo, la conservación de los intereses creados y la endogamia; 2) elegir por voto directo de los ciudadanos a los ministros de la Suprema Corte de Justicia de la Nación y reducir sus privilegios. Lo anterior para que la Suprema Corte tenga legitimidad democrática directa, producto de la soberanía popular. Así se rompería la objeción democrática de que se trata de un legislador que invalida leyes sin sustento democrático; 3) crear el Tribunal Constitucional para que sea el defensor de la Constitución. Dotar al Tribunal Constitucional de los más amplios medios procesales para garantizar el respeto de la Constitución (acciones ciudadanas de inconstitucionalidad, cuestión de constitucionalidad, control previo de constitucionalidad, etcétera). La Suprema Corte actual se transformaría en la última instancia de control de la legalidad; 4) establecer el amparo social para que los derechos económicos, sociales, culturales y ambientales, sean exigibles de manera directa, y no a través de la ley secundaria, en sede judicial. El amparo debe dejar de ser el instrumento de defensa de derechos de corte individual como aún lo es en los hechos; 5) introducir efectivamente el amparo en contra de actos de los particulares (poderes fácticos). En el Estado contemporáneo el poder fundamental que está detrás

390 Cárdenas Gracia, Jaime, Poderes fácticos e incompatibilidades parlamentarias, México, UNAM, 2006.

391 Sobre estos temas véase, por ejemplo, Alvarado, Arturo (ed.), La reforma de la justicia en México, México, El Colegio de México, 2008. 
Este libro forma parte del acervo de la Biblioteca Jurídica Virtual del Instituto de Investigaciones Jurídicas de la UNAM

del poder formal y que lo subordina debe ser sometido a la Constitución. Si los poderes fácticos actúan sin control alguno no puede haber Estado de derecho; 6) el sistema penal debe ser garantista. Las figuras del arraigo y de los testigos protegidos por ser elementos del derecho penal del enemigo debieran ser derogadas (derecho antidemocrático, no propio del Estado de derecho). El fin del derecho penal es la readaptación de los sentenciados y no la venganza del Estado, y 7) la sociedad debe incorporarse activamente a las instancias de seguridad pública, ministeriales y judiciales a través de: $a$ ) la auditoría ciudadana; $b$ ) la figura del jurado ciudadano y del amicus curiae; $c$ ) las acciones ciudadanas de inconstitucionalidad; $d$ ) el presupuesto participativo en el Poder Judicial, y e) la profundización en la transparencia de las actuaciones de seguridad pública, ministeriales y judiciales.

Los órganos constitucionales autónomos, como el Instituto Nacional Electoral (INE), el Banco de México, la Comisión Nacional de los Derechos Humanos, requieren de una gran apertura a la sociedad. Sus titulares deben ser designados por los ciudadanos y no por los partidos, el gobierno o los poderes fácticos. Es fundamental crear algunos órganos constitucionales autónomos como la Auditoría Superior de la Federación. En materia de transparencia y acceso a la información pública - de los órganos del Estado y de los poderes fácticos - es indispensable que el instituto Nacional de Transparencia, Acceso a la Información y Protección de Datos Personales (INAI) sea efectivamente un órgano constitucional autónomo y no una institución controlada por los tres partidos mayoritarios. Se necesita también un Consejo Económico y Social que represente a los sectores social y privado en la planeación del desarrollo nacional y el establecimiento de políticas públicas (este órgano tendría facultades consultivas y emitiría recomendaciones al Ejecutivo y a otros poderes y órganos en la definición e implementación de las políticas públicas en materia económica y social).

El cuarto elemento del Estado neoliberal supone la supremacía de los tratados internacionales por encima de la Constitución, principalmente los relacionados con el comercio, las inversiones y la propiedad, cuando las Constituciones nacionales debieran ser la norma suprema de las naciones mientras no existan las condiciones efectivas de un constitucionalismo mundial. El principio de supremacía constitucional deriva del carácter fundante que tiene la Constitución respecto a todo el orden jurídico restante, pero sobre todo, porque la Constitución es la expresión de la soberanía popular y del poder constituyente. ${ }^{392}$

392 Negri, Antonio, El poder constituyente. Ensayo sobre las alternativas de la modernidad, Madrid, Libertarias-Prodhufi, 1994. 
Este libro forma parte del acervo de la Biblioteca Jurídica Virtual del Instituto de Investigaciones Jurídicas de la UNAM

Sin embargo, los tratados en materia de comercio o de inversiones se superponen a las Constituciones. Por ejemplo, en el TLCAN se pactó la apertura de la petroquímica y la electricidad de manera peculiar: el gobierno reservó, en el capítulo VI del TLC, el petróleo y el gas, ${ }^{393}$ pero abrió el esquema de compras gubernamentales en el capítulo $\mathrm{X}$, y dio pie con ello, a la ampliación de la contratación de servicios con empresas extranjeras. Además, es importante decir, que acorde a la normatividad derivada del TLC, en el capítulo XV, relativo a la "Libre competencia, monopolios y Empresas de Estado", que si un Estado renuncia, privatiza o transfiere a los particulares un área económica sujeta a su control, ésta ya no podrá ser reasumida libremente, sino que tiene que abrir una ronda de negociaciones con las contrapartes. En caso de controversias, éstas serían ventiladas ante los paneles internacionales, y no ante los tribunales del Poder Judicial de la Federación.

Al aprobarse la reforma energética de 2013-2014, el Estado mexicano renuncia a la reserva que hizo para sí mismo en el capítulo VI sobre "Energía y petroquímica básica" del TLC, en donde apartó el petróleo, hidrocarburos y petroquímica básica, en sus diferentes fases de explotación, de la zona de libre comercio de Norteamérica. Lo anterior quiere decir que la modificación de la Constitución equivale a una reforma subrepticia del TLCAN, y nos coloca en los supuestos de los capítulos X, XI y XV del mismo, en donde, como ya se dijo, se estipula que si un Estado renuncia, privatiza o transfiere a particulares un área sujeta al control estatal, ésta ya no puede ser asumida libremente por el Estado. Todo lo anterior, a pesar de lo estipulado en el Acuerdo General sobre Aranceles Aduaneros (GATT), en donde se reconoce que México es un país en desarrollo, supone el derecho a recibir en todo momento un trato diferenciado y favorable, tanto en las negociaciones sobre concesiones arancelarias en las que no se le puede exigir reciprocidad absoluta, como respecto a las salvaguardias. En el protocolo de adhesión al GATT, México excluyó el petróleo, y en general, los hidrocarburos regulados en el artículo 27 constitucional de las obligaciones inherentes a ese convenio internacional. A juicio de algunos autores, el GATT tiene una jerarquía superior a la de cualquier tratado de libre comercio firmado

393 México definió cinco negativas precisas al firmar inicialmente el TLC: no a los contratos riesgo en exploración y explotación; no a la inversión extranjera en petroquímica básica; no a la garantía de suministro o seguridad de abasto; no a las ventas al menudeo (gasolinerías), y no a la liberalización del comercio exterior de petróleo crudo, gas natural y petrolíferos. Cordero, María Elena, Qué ganamos y qué perdimos con el TLC, México, Siglo XXIUNAM, 2003, p. 216. 
Este libro forma parte del acervo de la Biblioteca Jurídica Virtual del Instituto de Investigaciones Jurídicas de la UNAM www.juridicas.unam.mx

y ratificado por nuestro país, por ser un tratado multilateral y marco, lo que significaría que los hidrocarburos de México están jurídicamente excluidos del comercio internacional y de cualquier convención internacional regional que restringiera los derechos de la nación sobre ellos. ${ }^{394}$

Los capítulos X, XI y XV (capítulos sobre compras gubernamentales, inversiones y política en materia de competencia, monopolios y empresas de Estado) del TLCAN, en contra de la Constitución y del GATT, como ya se dijo, hacen nugatoria la reserva que sobre petróleo e hidrocarburos hace el capítulo VI del TLC, porque los capítulos X y XI abren las comparas gubernamentales y las inversiones en PEMEX y en el sector energético a los países parte del Tratado, y en cuanto al capítulo XV, cualquier reforma o medida administrativa que privatice o liberalice estos recursos, impide al Estado volver a asumirla libremente. Los demás TLC ratificados por México repiten en lo sustancial el esquema del TLCAN, lo que implica la liberalización y privatización de los recursos petroleros. Además de lo anterior, las negociaciones de la Ronda de Uruguay, que concluyeron formalmente con la reunión ministerial de Marrakesh, el 15 de abril de 1994, que creó la Organización Mundial del Comercio (OMG), promueven la liberalización progresiva del comercio, en forma gradual, mediante la reducción de obstáculos al comercio, incluyendo al petróleo y los hidrocarburos. ${ }^{395}$

Además, en el derecho internacional las trasnacionales tienen protegidas sus inversiones, vía los APRIS y el Convenio relativo a la Agencia Multilateral de Garantía a la Inversión (MIGA), a cargo del Banco Mundial, que blinda jurídicamente a los empresarios extranjeros contra cualquier medida que afecte sus intereses, incluyendo la expropiación. ${ }^{396}$ Por eso, argumentar

394 Witker, Jorge y Hernández, Laura, Régimen jurídico del comercio exterior de México, 3a. ed., México, UNAM, 2008, pp. 47 y ss.

395 Idem; Witker, Jorge (coord.), El tratado de libre comercio de América del Norte. Evaluación jurídica: diez años después, México, UNAM, 2005; López Velarde Estrada, Rogelio, "Energía y petroquímica básica", en Witker, Jorge (coord.), El tratado de libre comercio de América del Norte. Análisis, diagnóstico y propuestas jurídicas, México, UNAM, 1993, t. I, pp. 203-259; Jiménez Vázquez, Raúl, "Consideraciones en torno al capítulo de compras gubernamentales del TLCAN y su eventual impacto en el derecho mexicano", en Witker, Jorge (coord.), El tratado de libre comercio de América del Norte. Análisis, diagnóstico y propuestas jurídicas, op. cit., pp. 261-281.

396 Según lo señala la Multilateral Investment Guarantee Agency (MIGA) con base en la Convención que Establece la Agencia Multilateral de Garantía a la Inversión. Ésta es una aseguradora de inversiones privadas a nivel mundial con sede en Washington. Su membrecía está abierta a todos los países miembros del Banco Mundial, tiene la función de dar confianza y confort a la inversión extranjera directa (IED) que invierte en países en vías de desarrollo, dirigiéndose de manera especial a proyectos de desarrollo que sean económica, ecológica y socialmente sustentables. MIGA provee seguro a la inversión para efectos de transferencias de fondos, expropiación y medidas similares, incumplimiento de contrato, 
Este libro forma parte del acervo de la Biblioteca Jurídica Virtual del Instituto de Investigaciones Jurídicas de la UNAM

en esas controversias que nuestra Constitución debe prevalecer sobre los tratados, aunque es correcta, no parece muy realista. ${ }^{397}$

Por lo que las inversiones extranjeras no podrán ser afectadas ni siquiera aduciendo causas de interés general, excepto en supuestos limitativos y bajo los procedimientos previstos en el TLC. El TLCAN define en su artículo 1139 a la inversión extranjera como "aquélla en la que existe propiedad de un inversionista en territorio de una de las partes del tratado o cuando la remuneración depende sustancialmente de la producción, ingresos o ganancias de una empresa". La modificación de la Constitución en los artículos 25, 27 y 28 para permitir los contratos de explotación sobre los hidrocarburos entraña la plena armonía entre la Constitución y el TLCAN, y por tanto, las inversiones extranjeras de las industrias petroleras trasnacionales estarán plenamente protegidas y serán privilegiadas frente a los inversionistas privados nacionales que quedarán en posición de desigualdad y de discriminación en contra de lo establecido en el artículo 1o. de la Constitución y respecto a cualquier medida administrativa o legislativa nacional que pretenda revertir lo alcanzado o afectar la posición jurídica y económica de las trasnacionales del petróleo o de la electricidad.

Además, los criterios de solución de controversias no se basarán en los principios de área estratégica, exclusividad del sector público en la explotación del petróleo, inalienabilidad e imprescriptibilidad de los recursos del subsuelo, propiedad originaria de la nación sobre los recursos, sino por los criterios individualistas del derecho mercantil, civil y corporativo. Es decir, se ha privatizado el derecho público en México. El párrafo segundo del artículo 72 de la Ley de Petróleos Mexicanos ya indicaba con anterioridad a la reforma vigente, que las controversias en materia de hidrocarburos que se propiciaran entre el gobierno y las trasnacionales, podían decidirse ante instancias arbitrales o internacionales y no ante los tribunales nacionales.

guerra y disturbios civiles. Está facultada para que mediante resolución especial del Consejo, se cubran otros riesgos no comerciales, pero en ningún caso el de devaluación y depreciación de la moneda. Cabe señalar que MIGA al hacer el pago de la prima correspondiente, o convenir en su forma de pago, se subroga en los derechos del asegurado, adquiriendo todos sus derechos y acciones en contra del país anfitrión y cualesquier otros obligados. Este es un derecho que le reconocen todos los países miembros. Gómez-Palacio, Ignacio, Derecho de los negocios internacionales. Arbitraje Internacional, TLCAN, América Latina, CIADI, México, Porrúa, 2006, pp. 111 y 112.

397 Desde el amparo en revisión 1475/98, la Suprema Corte de Justicia de la Nación determinó que la Constitución está por encima de los tratados. Sin embargo, la reforma constitucional en materia de derechos humanos del 10 de junio de 2011 señala en el artículo 1o., párrafo segundo, de la Constitución, que la interpretación de los derechos debe realizarse pro homine. También debe considerarse lo resuelto por el Pleno de la Suprema Corte de Justicia de la Nación en la contradicción de tesis 293/2011. 
Este libro forma parte del acervo de la Biblioteca Jurídica Virtual del Instituto de Investigaciones Jurídicas de la UNAM

Con la reforma constitucional en materia energética que modificó el párrafo cuarto del artículo 28 de la Constitución para que el Estado pierda la exclusividad en la explotación de hidrocarburos y de electricidad, las controversias sobre los contratos de utilidades y producción compartidas, además de las licencias, se regirán por el derecho privado foráneo y no por el derecho público mexicano. PEMEX y la CFE estarán casi en un plano de igualdad jurídica con las empresas trasnacionales del sector energético (salvo por lo que ve a la llamada ronda cero que se deriva del artículo sexto transitorio de la reforma constitucional) y el Estado perderá cualquier poder de imperio en caso de suscitarse conflictos jurídicos. Tal como indicó la propaganda gubernamental, la transformación de PEMEX y de la CFE en empresas productivas del Estado, hacen que ésas pierdan en buena medida sus atributos de carácter público.

Además, el capítulo XI del TLCAN sobre inversiones, define un régimen de solución de controversias consistente con las características del Estado neoliberal basado en el sistema internacional de arbitraje. Es verdad que hipotéticamente se podría pactar en los contratos de producción y utilidad compartida, así como en las licencias, que las controversias se ventilen ante las instancias nacionales, pero la fuerza y costumbre de las grandes empresas petroleras y eléctricas, hacen suponer que no aceptarán soluciones de corte nacionalista para resolver las controversias jurídicas sobre la interpretación de esos contratos y licencias.

Los defensores del Estado neoliberal afirman inocentemente que la supremacía de ciertos tratados sobre las Constituciones como los tratados sobre derechos humanos, implican el desarrollo de un constitucionalismo mundial. Difiero de ese punto de vista, porque en la lucha entre los principios y derechos que reconocen los tratados sobre derechos humanos y las reglas que prevén los tratados y acuerdos de libre comercio, de inversiones o de propiedad intelectual, terminarán prevaleciendo los últimos sobre los primeros. La prueba de mi afirmación es el débil desarrollo en la realización supranacional de los derechos económicos, sociales, culturales y ambientales, y la incapacidad o desinterés de las instancias supranacionales de derechos humanos por protegerlos efectivamente, en relación con la manera en que protegen los derechos humanos de la primera generación.

Como quinto elemento del Estado neoliberal sostenemos que éste posee débiles mecanismos de derecho procesal constitucional para no proteger con suficiencia los derechos fundamentales de carácter social ni los derechos colectivos. En México, los actuales medios de defensa de la Constitución — principalmente el amparo, las acciones de inconstitucionalidad y las controversias constitucionales - no tutelan debidamente los principios de la 
Este libro forma parte del acervo de la Biblioteca Jurídica Virtual del Instituto de Investigaciones Jurídicas de la UNAM

Constitución. El amparo no garantiza de manera directa y amplia los derechos colectivos, sociales y difusos; no procede contra las reformas constitucionales; exige de manera decimonónica satisfacer el requisito de interés jurídico, y ahora, en algunos casos, el interés legítimo, como si las decisiones en los amparos contra leyes o contra disposiciones administrativas tuviesen un carácter privatista y no interesaran a toda la sociedad; además, la lista de las causales de improcedencia en el amparo son enormes y se han incrementado en la última reforma de 2013 a la Ley de Amparo, al grado que los jueces federales entran al fondo de los asuntos en tan sólo el 30\% de los casos. La legitimación procesal activa en las acciones de inconstitucionalidad se concede sólo a autoridades y a los partidos políticos en materia electoral; no existe legitimación procesal activa de los ciudadanos en este tipo de acciones, y se establecen requisitos excesivos para declarar la inconstitucionalidad de una ley - ocho votos de ministros de la Suprema Corte de Justicia de la nación y sólo pueden interponerse después de treinta días naturales de la entrada en vigor de la respectiva ley-. Las controversias constitucionales también están conferidas taxativamente a las autoridades que prevé la fracción I del artículo 105 de la Constitución, cómo si los asuntos materia de las mismas sólo interesaran a esas autoridades y no a toda la sociedad. Es decir, los actuales medios de defensa de la Constitución no están diseñados para defender integralmente a la Constitución - los derechos fundamentales, la división de poderes, los principios democráticos y la supremacía de la Constitución-.

En un Estado diferente al neoliberal se requeriría ampliar la capacidad de protección de los actuales instrumentos procesales e incorporar otros que no dejen parte de la Constitución sin protección. Por ejemplo, sería preciso incluir, entre otros: el amparo en contra de las reformas constitucionales; el control previo de constitucionalidad respecto de reformas constitucionales, tratados, leyes y reglamentos; las acciones colectivas en todas las materias y no sólo en unas cuantas; el amparo social; la cuestión de constitucionalidad, y las acciones ciudadanas de inconstitucionalidad.

Señalo como sexto elemento del Estado neoliberal, que en él existen instrumentos anticorrupción, pero éstos son compatibles con los intereses de las grandes corporaciones trasnacionales. En México, por ejemplo, la clase política no ha impulsado una Auditoría Superior de la Federación con características de órgano constitucional autónomo y con amplios poderes, ni ha querido aprobar una nueva Ley General de Transparencia y Acceso a la Información Pública que establezca como sujetos obligados de esa ley a los poderes fácticos nacionales y supranacionales, principalmente a las grandes corporaciones económicas y mediáticas. Para enfrentar la corrupción en 
Este libro forma parte del acervo de la Biblioteca Jurídica Virtual del Instituto de Investigaciones Jurídicas de la UNAM

nuestro país se requeriría contar con un decálogo amplio de herramientas institucionales, entre éstas, las siguientes:

1) La coordinación y vinculación entre todas las instituciones de investigación y resolución, federales y locales, que enfrentan la corrupción.

2) Ampliar los mecanismos de fiscalización en los ámbitos políticos y electorales.

3) Lograr la independencia y/o autonomía en todas las instituciones y órganos que realizan la accountability horizontal (tribunales, ministerio público, ASF, etcétera).

4) Dirigir la lucha en contra de la corrupción no sólo respecto a los poderes tradicionales sino también en cuanto a los poderes fácticos nacionales y supranacionales.

5) Propiciar mayor nivel, en cantidad y calidad, de participación y deliberación social en las decisiones públicas.

6) Transparentar de manera radical el aparato del Estado y a los poderes fácticos nacionales y supranacionales.

7) Establecer obligaciones concretas de rendición de cuentas en todos las instituciones públicas.

8) Revisar el sistema de responsabilidades de los servidores públicos para que las ilegalidades de éstos no queden en la impunidad.

9) Modernizar a la administración pública.

10) Basar efectivamente, y en todos los casos, la actuación del Estado y de sus servidores públicos en el respeto y garantía a los derechos fundamentales. 398

Sería muy oportuno tener un órgano anticorrupción con auténtica autonomía constitucional elegido por los ciudadanos a través del sufragio universal. Uno de los casos internacionales más conocidos es la Comisión Independiente contra la Corrupción de Hong Kong. ${ }^{399}$ Esta Comisión tiene por propósito no sólo recibir e investigar — más no juzgar - acusaciones de corrupción, sino también llevar a cabo campañas de concientización pública y hacer auditorías de las administraciones de departamentos y oficinas gubernamentales. Según Transparencia Internacional, el modelo de Hong Kong ha resultado ser eficaz porque ha existido la determinación de sus empleados en combatir la corrupción, porque el marco legal ha facilitado su

398 Cárdenas Gracia, Jaime y Mijangos Borja, María de la Luz, Estado de Derecho y Corrupción, México, Porrúa, 2005.

399 Transparencia Internacional, Libro de consulta, Transparencia Internacional, 2000, pp. 161-171. 
Este libro forma parte del acervo de la Biblioteca Jurídica Virtual del Instituto de Investigaciones Jurídicas de la UNAM

trabajo y porque tanto el concepto de la prevención como el procesamiento legal ha sido competencia de la Comisión. Una característica fundamental de la agencia anticorrupción de Hong Kong reside en que comités ciudadanos monitorean su trabajo, con lo que se aumenta la confianza pública en esa institución.

En México, considero que en materia anticorrupción - lo que no hace el Estado neoliberal - se debería reflexionar en propuestas concretas como las siguientes:

1) Una Comisión de la Verdad para investigar, sancionar y hacer pública la corrupción política, privada y social del pasado.

2) Hacer de la Auditoría Superior de la Federación un órgano constitucional autónomo sin que sea susceptible de cooptación por los partidos.

3) Fortalecer su autonomía orgánica, de gestión, financiera-presupuestal y jurídica.

4) Transparentar el ejercicio presupuestal de la Secretaría de Hacienda y el control económico financiero del Estado en todas sus fases y no sólo al final de los procedimientos como acontece ahora.

5) Ampliar el universo de lo fiscalizado, esto es, los alcances y profundidad de las auditorías practicadas.

6) Establecer instrumentos que permitan de manera regular el control previo y concomitante de las finanzas públicas, no sólo a partir de denuncias, sino de oficio, además de conservar el control a posteriori que hoy prevalece.

7) Permitir que la Auditoría Superior pueda conocer con mayor amplitud de cuentas públicas del pasado - hasta diez años-, y sobre ellas, realizar observaciones y recomendaciones cuando no se hubiesen advertido irregularidades en el pasado o apareciesen datos o información nueva.

8) Otorgarle competencia a la Auditoría Superior para conocer y procesar responsabilidades administrativas respecto de los servidores públicos, y directamente, facultarla para consignar ante los jueces penales federales, los asuntos que así lo ameriten.

9) Prohibir la constitución de fondos y fideicomisos en la administración pública.

10) Darle el rango de ley formal y materialmente al presupuesto de Egresos.

11) Restringir las facultades de la Secretaría de Hacienda para alterar el presupuesto aprobado. 
Este libro forma parte del acervo de la Biblioteca Jurídica Virtual del Instituto de Investigaciones Jurídicas de la UNAM

12) Publicitar ampliamente las subvenciones, subsidios y bonificaciones fiscales que se otorgan a grupos y sectores, para que la sociedad tenga conocimiento cabal de a quién se beneficia por la vía tributaria.

13) Lograr que la Auditoría Superior de la Federación, además de contar con autonomía constitucional, garantice un funcionamiento interno y administración transparente, de cara a la sociedad.

14) Establecer mecanismos ciudadanos y de especialistas para fiscalizar a la propia Auditoría Superior de la Federación.

15) Darle a esta institución competencias en la fiscalización de las participaciones federales a estados, ciudad de México y municipios.

16) Establecer un registro nacional de servidores públicos y proveedores sancionados para evitar que servidores públicos o proveedores cambien de domicilio para seguir delinquiendo y gozando de impunidad.

17) Aprobar la Ley General de Contraloría Social para abrir canales de participación ciudadana y control social. ${ }^{400}$

La corrupción en México tiene su origen, desde nuestro punto de vista, en lo siguiente: $a$ ) en el poder formal e informal ejercido sin límites democráticos ni jurídicos, $b$ ) en la debilidad o ausencia de instituciones que controlen ese poder, y $c$ ) en la ausencia o insuficiencia de mecanismos de participación ciudadana que le permitan a la sociedad vigilar y controlar el poder. 401

En la reciente reforma anticorrupción nunca se analizaron durante el trabajo parlamentario las causas y las características de la corrupción en México. Me pregunto cómo se pueden proponer soluciones sin conocer las causas y las características de la corrupción en México. Hagamos primero ese análisis.

La reforma obvia y pasa de puntitas por lo fundamental. Las causas y las condiciones de la corrupción en México tienen que ver con el poder, la forma en que éste surge, se ejerce y no se limita o controla. En ese sentido, las medidas anticorrupción tendrían que ver con las limitaciones al poder,

${ }^{400}$ La reforma constitucional a los artículos 79, 108, 109, 113, 114, 116, fracción V y 122, base quinta de la carta magna que estableció el sistema nacional anticorrupción, y fue publicada en el Diario Oficial de la Federación del 27 de mayo de 2015, no impulsa un auténtico sistema anticorrupción. Grea una gran burocracia que será controlada por los partidos políticos mayoritarios.

401 Cárdenas Gracia, Jaime y Mijangos Borja, María de la Luz, Estado de derecho y corrupción, op. cit. 
Este libro forma parte del acervo de la Biblioteca Jurídica Virtual del Instituto de Investigaciones Jurídicas de la UNAM

con domar al poder formal e informal, es decir, ser instrumentos de contrapoder.

¿Y quién tiene el poder en México? El presidente, las grandes empresas nacionales y trasnacionales, los organismos financieros supranacionales, el duopolio televisivo, las cúpulas de los tres partidos mayoritarios. La reciente reforma anticorrupción no se proyecta sobre ellos. Deja el poder del presidente intacto. No regula el poder inmenso de las empresas nacionales ni trasnacionales, no limita la influencia indebida de los organismos financieros supranacionales en México, ni reduce el poder del duopolio o el poder arbitrario de los tres grandes partidos.

¿En qué consiste la reforma anticorrupción? En un esquema institucional elaborado por la oligarquía y sus escribanos. Una estructura jurídica insuficiente y de realización a largo plazo que estará controlada por el presidente y los tres partidos mayoritarios.

La reforma anticorrupción aprobada por el llamado Constituyente Permanente es sumamente defectuosa. Apunto quince críticas:

1) No procede de manera amplia la extinción de dominio por delitos y faltas graves relacionadas con la corrupción - artículo 22 constitucional-. Sólo procede la extinción de dominio por delitos de enriquecimiento ilícito.

2) Los órganos internos de control que prevé el dictamen serán controlados por los tres partidos mayoritarios porque ellos tendrán el poder político para imponer a sus titulares - artículos 28 y 74 de la Constitución-.

3) El diseño del Tribunal Federal de Justicia Administrativa - artículo 73, fracción XXIX-H de la Constitución - no augura independencia ni imparcialidad. Estarán detrás de él el titular del Ejecutivo y las cúpulas de los tres partidos mayoritarios.

4) Las auditorías al desempeño sólo dan lugar a recomendaciones y no a responsabilidades - artículo 74, fracción VI- de la Constitución.

5) La Auditoría Superior de la Federación seguirá dependiendo constitucionalmente de la Cámara de Diputados; es decir, de los partidos mayoritarios. No se propone su autonomía constitucional y sus competencias, aunque se incrementan, no son las esperadas para enfrentar la corrupción propiciada desde el poder presidencial y desde la influencia indebida de los poderes fácticos — artículos 74 y 79 de la Constitución-.

6) Las declaraciones patrimoniales y de intereses no son públicas - artículo 108 de la Constitución-. 
Este libro forma parte del acervo de la Biblioteca Jurídica Virtual del Instituto de Investigaciones Jurídicas de la UNAM

7) El presidente sigue intocado. No es susceptible de responsabilidad administrativa y el artículo 108 de la Constitución, tanto el vigente como el propuesto, lo dota de impunidad.

8) El Poder Judicial tiene un tratamiento privilegiado. No forma parte del Sistema Nacional Anticorrupción - artículo 109 de la Constitución-.

9) El Comité Coordinador del Sistema Nacional Anticorrupción, además de ser una estructura que no da cabida a Estados y municipios, estará influido por la presencia del Ejecutivo a través de la participación de la Secretaría del Ejecutivo responsable del control interno - artículo 113 de la Constitución-.

10) El Comité Coordinador sólo producirá recomendaciones que no son vinculantes - artículo 113 de la Constitución-.

11) El plazo de prescripción en la materia es de siete años, por qué no de diez años; o bien, por qué los delitos y las faltas relacionadas con la corrupción no son imprescriptibles - artículo 114 de la Constitución-.

12) El Sistema Nacional Anticorrupción es antifederalista. No participan los Estados y municipios en su comité —artículo 113 de la Constitución-.

13) El desarrollo de la reforma se realizará a través de leyes generales en donde no participarán las legislaturas de los Estados.

14) La reforma constitucional no precisa cuáles son los delitos relacionados con la corrupción ni cuáles son las faltas graves de carácter administrativo. Todo se deja a la legislación secundaria.

15) La reforma no alude a los conflictos de interés ni a las incompatibilidades de los servidores públicos.

En síntesis, la reforma constitucional anticorrupción mexicana constituye una simulación que no resolverá la corrupción. Como dijimos, consiste en proponer un andamiaje institucional que será controlado por el titular del Ejecutivo y por los tres partidos mayoritarios. Es un dictamen que no enfrenta al poder en México, que es el productor de la corrupción en el país, y es una propuesta que no brinda a los ciudadanos amplios mecanismos de participación ciudadana para enfrentarla.

El Estado neoliberal reduce la democracia participativa, deliberativa y comunitaria - de los pueblos originarios - e impulsa una democracia electoral manipuladora de los derechos políticos de los ciudadanos - séptimo elemento del Estado neoliberal- - Resulta necesario el establecimiento 
Este libro forma parte del acervo de la Biblioteca Jurídica Virtual del Instituto de Investigaciones Jurídicas de la UNAM

de mecanismos de democracia participativa y deliberativa ${ }^{402}$ para acercar a la sociedad con la autoridad, para romper ese divorcio que es contrario al principio de soberanía popular. ${ }^{403}$ Así, entre otros, debieran existir los siguientes instrumentos: el referéndum; el plebiscito; la revocación de mandato; la iniciativa legislativa popular a cargo de cada ciudadano; el presupuesto participativo; la afirmativa ficta; la auditoría social; el derecho de audiencia pública ante las autoridades; el derecho de voz ciudadana en los cabildos; la consulta popular sin los requisitos que hoy establece la norma constitucional; las acciones colectivas y de tutela en todas las materias; la acción popular de inconstitucionalidad; la inconstitucionalidad por omisión legislativa, administrativa o derivada de otros órganos de poder; el derecho de resistencia; la desobediencia civil pacífica y objeción de conciencia para que las instituciones y normas sean revisadas cuando el marco jurídico es insuficiente para satisfacer derechos humanos o principios democráticos; el amicus curiae para que los ciudadanos y los sectores sociales se involucren en forma institucional y constructiva en los procesos judiciales, y la obligación de deliberación pública y transparente en todas las instancias colegiadas del poder público del país.

El Estado neoliberal no impulsa la democracia participativa ni la deliberativa ni la comunitaria, prefiere una democracia electoral representativa de baja intensidad, en donde lo importante - los tratados de libre comercio, militares o de seguridad - no sean votados ni decididos de ninguna manera por los ciudadanos. De manera deliberada se busca que los ciudadanos queden alejados de las decisiones que implican aprobar o rechazar las reformas del neoliberalismo. En nuestro país no se reconoció el derecho de consulta para que los ciudadanos opinaran sobre la reforma energética ${ }^{404}$, y además,

402 Viola, Francesco, La democracia deliberativa entre constitucionalismo y multiculturalismo, México, Universidad Nacional Autónoma de México, 2006.

403 Cortina, Adela, Ética aplicada y democracia radical, Madrid, Tecnos, 1993.

404 El 30 de octubre de 2014, el Pleno de la Suprema Corte de la Nación resolvió, por gran mayoría, la consulta que había planteado el partido Morena. Esa decisión es ejemplo del compromiso de las más altas instancias judiciales de un país con el neoliberalismo. Nosotros pensamos que la decisión de la Corte mexicana era antijurídica por los siguientes motivos: a) porque entiende el concepto ingresos y gastos del Estado de manera amplia, cuando el sentido de las restricciones del artículo 35, fracción VIII, de la Constitución, es entender esas restricciones de manera estricta y limitada, para no impedir el derecho humano a la participación política a través de las consultas; $b$ ) en la interpretación de los derechos humanos - la participación en la consulta es un derecho humano de carácter político- se debe proteger en la mayor medida posible a las personas, por lo que la interpretación de las normas que afecten derechos fundamentales, tiene que ser progresiva y maximizadora de los derechos fundamentales, según indican los párrafos segundo y tercero del artículo lo. de la Constitu- 
Este libro forma parte del acervo de la Biblioteca Jurídica Virtual del Instituto de Investigaciones Jurídicas de la UNAM

se incumplió con el Convenio 169 de la OIT, pues jamás la reforma estructural energética se consultó previamente a los pueblos originarios. Tampoco los mexicanos han votado la integración de nuestro país a esquemas de seguridad hemisférica como el ASPAN (Acuerdo para la Prosperidad y Seguridad de América del Norte) o a la Iniciativa Mérida. Todos los tratados de libre comercio, de inversión o relacionados con la propiedad intelectual, quedan excluidos de la decisión de los ciudadanos, al igual que las grandes obras de infraestructura que sirven para explotar intensiva y extensivamente los recursos naturales que son de las naciones respectivas.

El octavo elemento del Estado neoliberal implica la entrega del patrimonio de las naciones - sus recursos naturales - y de su explotación a los intereses foráneos. Los recursos naturales y su explotación deberían reintegrarse a las naciones y explotarse por los organismos del Estado para garantizar la soberanía de los países, sobre todo los que se encuentran en vías de

ción; c) la interpretación de la Corte no ponderó las colisiones normativas, en relación con el caso concreto, entre los párrafos segundo y tercero del artículo lo. de la Constitución con el artículo 35, fracción VIII, del mismo texto fundamental. Si se hubiese realizado esa ponderación, la conclusión necesaria hubiese decantado la decisión de la Suprema Corte a favor de la maximización del derecho de participación política de los ciudadanos a través de la consulta y no de su limitación; d) el concepto ingresos y gastos del Estado alude a las contribuciones fiscales y al presupuesto; la consulta estaría prohibida si los promoventes de la misma pretendieran con ella derogar o cambiar de manera directa, y a través de ella, los impuestos o el gasto del Estado; e) la finalidad de la pregunta formulada por Morena no era la de alterar el régimen fiscal vigente ni impedir el presupuesto público; su objetivo era preguntar sobre el sistema de contratación aprobado por la reforma constitucional del 20 de diciembre de 2013 en materia energética; $f$ ) llevar a sus extremos el argumento de la Corte implica negar o prohibir las consultas sobre cualquier asunto porque casi no hay materia susceptible de ser consultada, que no tenga relación, aunque sea de manera indirecta, con los ingresos y gastos del Estado; $g$ ) el derecho a la consulta consagrado en la Constitución no la prohíbe sobre las reformas constitucionales; el artículo 35, fracción VIII, del texto fundamental, no indica que entre las materias vedadas estén las reformas constitucionales; $h$ ) el órgano revisor de la Constitución es un órgano derivado y vicario de la Constitución, y debe, como el resto de los Poderes, órganos y procedimientos, estar sujeto al cumplimiento de los preceptos de la Constitución. Sobre las reformas constitucionales cabe la consulta al no estar esta materia restringida por el artículo 35, fracción VIII, de la Constitución; $\imath$ ) la consulta propuesta por Morena no vulnera los principios del artículo 40 de la Constitución porque no tiene por finalidad alterar la forma republicana, representativa, democrática, federal o laica del Estado, sino, por el contrario, pretende salvaguardar esos principios a fin de garantizar la soberanía y la independencia nacional, así como el pleno respeto de los derechos de los ciudadanos a participar en los asuntos públicos sobre todas las materias que no estén expresa y estrictamente prohibidas por el artículo 35, fracción VIII, de la Constitución, y j) la decisión mayoritaria de la Corte - excepción del voto del Ministro Cosío Díaz - hace nugatoria la democracia participativa en México, y cancela los derechos de los ciudadanos a cuestionar las decisiones de los poderes y órganos públicos del país, incluyendo al poder revisor de la Constitución. 
Este libro forma parte del acervo de la Biblioteca Jurídica Virtual del Instituto de Investigaciones Jurídicas de la UNAM

desarrollo. Sería fundamental en los países en vías de desarrollo nacionalizar la Banca y contemplar en la Constitución que todos los recursos naturales: hídricos, hidrocarburos, minas, recursos renovables y no renovables, son patrimonio exclusivo de la nación. Los principios constitucionales de este diseño implicarían: considerar recursos naturales y minerales en todos sus estados, los hidrocarburos, el agua, el aire, el suelo y el subsuelo, los bosques, la biodiversidad, el espectro electromagnético, etcétera; estimar que el patrimonio natural será de interés público y de carácter estratégico para el desarrollo sustentable del país; se debe prohibir el comprometer la soberanía sobre los recursos naturales; la explotación de recursos naturales estará sujeta a consulta - libre, previa e informada - con la población afectada, y en el caso de las comunidades indígenas, además del derecho de consulta, el Estado debería garantizar que los pueblos originarios reciban un porcentaje sobre los beneficios de la explotación.

El Estado neoliberal se basa en el saqueo de los recursos naturales, ${ }^{405}$ principalmente de los recursos naturales de los países pobres o en vías de desarrollo, tal como se explica en la geopolítica y lo ilustró magistralmente el jurista alemán Carl Schmitt. ${ }^{406}$ El control de los países poderosos sobre los débiles tiene por finalidad el dominio, administración y manejo de sus territorios y recursos naturales. En el Estado neoliberal están en disputa, entre las grandes potencias, los recursos naturales de los Estados en vías en desarrollo. Por eso, el Estado neoliberal está dirigido por una lógica implacable de acumulación de riqueza a costa del sufrimiento humano, el medio ambiente, la garantía del derecho a la salud o los derechos de las futuras generaciones. En países como México, debe entenderse que sus recursos naturales y la explotación de los mismos constituyen la soberanía de la nación, como se ha entendido desde el descubrimiento de América, y principalmente, como lo concibió el Constituyente de Querétaro de 1917 cuando se redactó la versión original del artículo 27 constitucional. ${ }^{407}$

El noveno elemento del Estado neoliberal consiste en la inadecuada defensa de la soberanía nacional. Las instituciones del Estado debieran tomar las decisiones económicas a partir de los deseos y necesidades de los pueblos. Las consultas para determinar y definir el diseño de las políticas económicas con el FMI, el Banco Mundial, el Departamento del Tesoro o del Comercio

405 Cárdenas Gracia, Jaime, "La minería en México: despojo a la nación”, Revista Cuestiones Constitucionales, México, núm. 28, enero-junio de 2013, pp. 35-74.

406 Schmitt, Carl, El nomos de la Tierra en el derecho de dentes del "jus publicum europaeum", Madrid, Centro de Estudios Políticos y Constitucionales, 1979.

407 Cárdenas Gracia, Jaime, En defensa del petróleo, México, UNAM, 2009. 
Este libro forma parte del acervo de la Biblioteca Jurídica Virtual del Instituto de Investigaciones Jurídicas de la UNAM

de los Estados Unidos deben quedar proscritas si no existe la aprobación de las sociedades. Los gobiernos no pueden estar limitados por otro gobierno o por intereses internacionales ajenos a los deseos, necesidades, voluntad y derechos de todos los habitantes de los países. En el Estado neoliberal no existe autodeterminación en la economía, en la energía, el medio ambiente, la salud, ni tampoco en la seguridad pública o en la nacional. La teoría del Estado neoliberal estimula gobiernos periféricos y subordinados a intereses exógenos. Por ello, principios del derecho internacional como el de no injerencia en los asuntos internos, están en decadencia.

La soberanía nacional en términos externos e internos es una quimera. Externamente condicionan la vida nacional a los intereses de otras potencias. Internamente, los poderes fácticos han domeñado y secuestrado al Estado y sus instituciones. No existen posibilidades para que los nacionales autodeterminen su destino. Las sociedades están a merced de presiones e intereses nacionales y trasnacionales que escapan a las necesidades, intereses y decisiones internas.

Para enfrentar estas circunstancias y frente al Estado neoliberal, un paso necesario consiste en modificar el procedimiento de aprobación de tratados en muchos países. Los tratados y acuerdos internacionales que comprometan la soberanía nacional, tengan que ver con la economía, el comercio internacional, la seguridad nacional y pública, y los derechos humanos, deben ser aprobados con el mismo procedimiento de reforma constitucional previsto en las leyes fundamentales más la aprobación ciudadana vía referéndum. Se debe impedir que las elites nacionales e internacionales determinen el alcance de la soberanía. Son los ciudadanos los que deben definirla.

Los tratados vigentes que tienen que ver con el comercio internacional, la economía, la seguridad nacional y pública, y los derechos humanos, debieran ser revisados. Si son lesivos a la soberanía nacional procede su denuncia y, en su caso, la abrogación. Los gobiernos deben propugnar y luchar por la democratización y transparencia de las instituciones internacionales de las que forman parte. Los principios del Estado constitucional y democrático de derecho deben ser realidad en el ámbito internacional. La globalización precisa ser un proceso que esté en manos de las sociedades del planeta y debe realizarse de abajo hacia arriba.

En el ámbito interno, la manera de alcanzar soberanía consiste en domeñar y limitar el poder de los poderes fácticos para que las instituciones del país no estén secuestradas. Las instituciones de los países carecen de legitimidad porque están sometidas a los poderes fácticos (televisoras, empresa- 
Este libro forma parte del acervo de la Biblioteca Jurídica Virtual del Instituto de Investigaciones Jurídicas de la UNAM

rios, ejército, iglesias, sindicatos y partidos). Si queremos consolidar las democracias estamos obligados a sujetar a derecho los factores reales de poder.

El décimo elemento del Estado neoliberal entraña la implantación del modelo económico globalizador para someter al derecho y al Estado nacional en su provecho. La economía debe estar al servicio de las personas y debe ser el instrumento para garantizar derechos económicos, sociales y culturales. La economía no puede estar al servicio de élites y oligarquías que están ajenas a cualquier control democrático. ${ }^{408}$

En muchos países, el Estado neoliberal se ha caracterizado por: privatizar áreas estratégicas y prioritarias del Estado; favorecer al capital especulativo internacional; mermar los derechos de los trabajadores, y en general, los derechos sociales y económicos de los habitantes; beneficiar con privilegios fiscales y de otro tipo a las principales empresas nacionales y trasnacionales que operan en los territorios respectivos; estimular el libre comercio y ahogar el mercado interno; liquidar la industria nacional; desistir de cualquier tipo de crecimiento y desarrollo económico por vías domésticas, y en síntesis, catalizar las condiciones de pobreza en las que viven millones de seres humanos.

Como dice un especialista mexicano:

...mientras la economía esté subordinada a los intereses del capital financiero, dada nuestra gran dependencia respecto de ellos, no hay perspectivas de que cambie la política económica predominante para poder favorecer la esfera productiva y el empleo. El Estado debe retomar el manejo soberano de la política económica para asegurar las condiciones productivas y financieras a favor del crecimiento sostenido con pleno empleo. ${ }^{409}$

En este sentido, el Estado anti-neoliberal debe: intervenir en la economía para recuperar las funciones estratégicas previstas en el párrafo cuarto del artículo 28 constitucional; ser el rector de la economía nacional; recuperar el control sobre el sector bancario y financiero y orientarlo al desarrollo; revisar el TLCAN; contar con una vigorosa banca de desarrollo; destinar muchísimos más recursos para la obra pública y la infraestructura; contar con una política industrial; provocar la fortaleza del mercado interno y el apoyo a los productores nacionales; garantizar la autosuficiencia alimentaria mediante una política de apoyo a los productores del campo; generar ahorros mediante una política de austeridad respecto a sueldos y presta-

408 Sotelo, Ignacio, "El futuro del Estado social", op. cit., pp. 14-23.

409 Huerta González, Arturo, Hacia el colapso de la economía mexicana. Diagnóstico, pronóstico y alternativas, México, UNAM, 2009, p. 15. 
Este libro forma parte del acervo de la Biblioteca Jurídica Virtual del Instituto de Investigaciones Jurídicas de la UNAM

ciones de la alta burocracia; eliminar los privilegios fiscales que favorecen a las grandes empresas nacionales y trasnacionales; aprobar una reforma fiscal que sea equitativa y proporcional — grave más a quien más tieneincentivar una política social ambiciosa para garantizar los derechos económicos, sociales y culturales; reformar el artículo 28 constitucional para, por un lado, profundizar en los principios que proscriben los monopolios, y por el otro, permitir que una parte de las reservas del Banco de México se destinen al desarrollo. 
Este libro forma parte del acervo de la Biblioteca Jurídica Virtual del Instituto de Investigaciones Jurídicas de la UNAM

\section{CONCLUSIONES}

En esta obra hemos deseado, a través del marco del derecho, exponer la evolución del Estado nación desde su fundación después del Renacimiento. Tanto la ciencia política como la teoría del Estado han explicado que las etapas de ese proceso comprenden al Estado absoluto, al Estado liberal y al Estado del bienestar. En la economía y en ciencia política se señalan que hoy dominan las condiciones del Estado neoliberal. Por su parte, los juristas han elaborado durante las últimas décadas la construcción de lo que se define como Estado constitucional.

Este último es un concepto prescriptivo, que aunque prevaleciente en la teoría jurídica continental europea y latinoamericana, tiene pocos visos de materialización, tanto a nivel nacional como mundial, porque carece de fundamentos económicos, políticos y sociológicos que le den sustento. En la facticidad lo que tenemos, y en todo su esplendor, son las manifestaciones de lo que hemos nombrado como el Estado neoliberal.

El Estado constitucional es un concepto problemático. En estas páginas lo hemos cuestionado y esbozado diez críticas sobre su construcción. Dentro de los elementos debatibles del Estado constitucional mencionamos los siguientes:

1) Las teorías del Estado constitucional prescinden de las condiciones económicas vigentes y de las teorías económicas que las analizan.

2) Las teorías del Estado constitucional eluden una teoría sobre el poder que dé cuenta del papel contemporáneo de los poderes fácticos, de la hegemonía cultural, ideológica y mediática, y de la organización y diseño del poder formal.

3) Las teorías del Estado constitucional descuidan formas de organización social y democrática relacionadas con la democracia participativa y deliberativa, así como con las manifestaciones de la democracia comunitaria; es decir, no advierten las capacidades transformadoras de una democracia radical que haga viables los fines del Estado constitucional. 
Este libro forma parte del acervo de la Biblioteca Jurídica Virtual del Instituto de Investigaciones Jurídicas de la UNAM

4) Las teorías del Estado constitucional son poco exigentes con realidades contemporáneas como la plurinacionalidad y el multiculturalismo.

5) Aunque existen autores que se han preocupado por la globalización del constitucionalismo, las teorías del Estado constitucional no abundan sobre las ventajas, desventajas y posibilidades que para el constitucionalismo tiene la globalización.

6) Las teorías del Estado constitucional con su concepto de democracia constitucional favorecen la posición de los más privilegiados del sistema, y no la de las minorías menos aventajadas.

7) Las teorías del Estado constitucional presentan rasgos profundamente elitistas: las élites burocráticas supranacionales definen el sentido y alcance de los derechos humanos.

8) Los guardianes del Estado constitucional - los jueces constitucionales - no poseen legitimidad democrática de origen.

9) El principio de proporcionalidad, método privilegiado para resolver los conflictos entre principios constitucionales, no sólo deslava a los derechos humanos, sino que es un método que mantiene el status quo.

10) Las teorías del Estado constitucional son una ficción jurídica sin asideros en la realidad. Son una inspiración, un noble sueño, aunque reconozco que pueden poseer capacidades transformadoras.

Sobre los diez temas anteriores hemos argumentado, y al mismo tiempo, tratamos de justificar que el Estado neoliberal es la realidad que nos inunda desde los centros hegemónicos de poder mundial y desde los mercados trasnacionales. Esta forma del Estado vigente se vale de la economía y de la geopolítica para imponerse por vías económicas, políticas, diplomáticas, militares y jurídicas.

Se trata también de una forma de Estado problemática porque carece del consenso y de la legitimidad política necesarias para su supervivencia. Es probable que ante el descontento mundial, por la desigualdad oprobiosa e imperante vigente, tenga que ser modificado por nuevas formas del Estado nación, aunque también es posible que el Estado nación, que ha estado vinculado al capitalismo en los últimos quinientos años, sea sustituido por nuevas formas de dominación política.

Los juristas tenemos mucho que ver en este debate. El noble sueño de neoconstitucionalistas, como Ferrajoli, que insisten y piden un constitucionalismo mundial, debe ser rescatado, pero con plenitud de conciencia. La globalización del constitucionalismo no será posible sin grandes luchas, tanto jurídicas como económicas, sociales y políticas. Las instituciones inter- 
Este libro forma parte del acervo de la Biblioteca Jurídica Virtual del Instituto de Investigaciones Jurídicas de la UNAM

nacionales que definen la marcha económica, política y militar del mundo requieren ser democratizadas. A nivel interno de los Estados, no puede transformarse la realidad vigente sin una profunda democratización de las sociedades nacionales y de las instituciones políticas.

Las aspiraciones nacionales y mundiales del constitucionalismo pueden ser realidad en algún momento, pero tal exige cambiar el modelo económico neoliberal vigente, tanto en sus facetas ideológicas, como en las institucionales y económicas. Por ello, como lo explicamos en el desarrollo del libro, el neoliberalismo como ideología implica asumir que sus piezas y elementos básicos constituyen el discurso dominante de nuestro tiempo, que las élites económicas y políticas lo consideran como dogma verdadero. La ideología neoliberal sostiene una imagen idealizada del libre mercado y estima que los individuos son seres descontextualizados y egoístas que sólo persiguen su interés y satisfacción mediante el consumo. El neoliberalismo como ideología recela de la intervención económica del Estado en la economía a menos que sea para favorecer al gran capital especulativo y financiero, condena a las empresas públicas, rechaza el rol del sindicalismo reivindicativo, descarta las negociaciones colectivas obrero-patronales, desconfía de las normas medioambientales y fiscales que entorpecen el funcionamiento del libre mercado. Cualquier esquema institucional y jurídico que entrañe sustituir o limitar el desempeño individual es reputado como una afectación a la libertad y el progreso.

Como forma de gobierno, el neoliberalismo se basa en valores empresariales como la competencia, el interés, la descentralización, la deslocalización, el fortalecimiento del poder individual y las limitaciones a los poderes centrales. Se estima que las instituciones estatales deben funcionar bajo los parámetros de competencia, eficiencia y eficacia de las empresas privadas, y que en lugar de promover el bien común o el desarrollo de la sociedad civil y de la justicia social, el gobierno debe impulsar la transformación de la mentalidad burocrática y sustituirla por visiones empresariales para garantizar el libre mercado. Los empleados del gobierno no se deben ver a sí mismos como garantes del bien público sino como participantes responsables del funcionamiento del mercado.

En cuanto a las medidas económicas del neoliberalismo, éstas se caracterizan por desregular la economía, liberalizar el comercio y la industria y privatizar las empresas estatales. Específicamente sus tendencias económicas se caracterizan por lo siguiente: desmantelamiento de las regulaciones que existían sobre diferentes actividades, destacando, entre otras, a las financieras, las que asumen un rol fundamental en la orientación de las acti- 
Este libro forma parte del acervo de la Biblioteca Jurídica Virtual del Instituto de Investigaciones Jurídicas de la UNAM

vidades productivas; debilitamiento de la posición negociadora del trabajo mediante distintas desregulaciones y acotamientos de las relaciones obreropatronales; estrechamiento financiero y reglamentario en la prestación de servicios de bienestar social; reorganización de las actividades productivas para reducir costos, incluyendo la introducción de innovaciones tecnológicas, la reducción de las plantillas laborales y la relocalización geográfica de porciones importantes de los procesos productivos o de actividades completas; reducción del déficit fiscal, dejando el peso para lograrlo sobre el gasto del gobierno, como consecuencia de las acciones de desgravación impositiva; privatización de empresas públicas y privatización de servicios públicos al igual que la subcontratación de actividades como parte de la provisión de servicios públicos; política macroeconómica centrada en la estabilidad de precios y abandono de la política fiscal macroeconómica que anteriormente en el modelo keynesiano servía para redistribuir la riqueza, y finalmente, liberalización de los flujos de comercio y capital entre países.

El neoliberalismo en sus versiones actuales carece de rasgos y signos de humanidad y conduce a profundas desigualdades nacionales y planetarias. Por eso, muchas voces exigen un neoliberalismo global con rostro humano, ${ }^{410}$ lo que de suyo parece difícil de conseguir, ya que está en juego la acumulación constante y expansiva del capital y el poder de los centros hegemónicos. Un neoliberalismo global con rostro humano implicaría reducir los grandes beneficios de las trasnacionales y limitar el poderío militar y político de las grandes potencias.

Desde luego que ello es posible mediante la toma de conciencia y las luchas de las sociedades. Tal como ocurrió a finales del siglo XIX, sectores sociales proactivos en las naciones, pueden conseguir el milagro de la matización de los efectos más nocivos del neoliberalismo globalizador y hasta podrían obtener su sustitución pacífica por otras formas de organización política y económica.

La pretensión del libro desde su inicio fue la de vincular las formas estatales con el modelo de producción económica. Durante el Estado absoluto dominaron las estructuras mercantilistas, pero al final de ese periodo, fue muy importante la fisiocracia para pasar a la fase del Estado liberal. Durante el siglo XIX, consecuencia de la revolución industrial, la economía de mercado de carácter nacional y proteccionista está relacionada con el Estado liberal de derecho. El Estado del bienestar es el producto de una economía de mercado, en donde el capital y el trabajo lograron acordar y consensar sus diferencias para pacificar a las sociedades; la economía se basó

410 Stiglitz, Joseph E., El malestar en la globalización, Madrid, Santillana, 2002, pp. 307 y ss. 
Este libro forma parte del acervo de la Biblioteca Jurídica Virtual del Instituto de Investigaciones Jurídicas de la UNAM

en cuasi monopolios nacionales sobre los que las grandes potencias ejercían tutela y protección, para que esas empresas de origen nacional gozaran y ejercieran la libertad de comercio en el mundo entero. El Estado constitucional presupone la existencia de un Estado del bienestar económico que tiene visos de existencia en los países desarrollados, aunque en algunos de ellos también ese presupuesto es problemático, pero que en los que están en vías de desarrollo o son subdesarrollados carece de existencia.

Por su parte, el Estado neoliberal protege la propiedad privada, mantiene el imperio de la ley y fortalece el libre mercado y el libre comercio. En el Estado neoliberal son divisa: la inviolabilidad de los contratos y los derechos a la libertad de expresión y de acción; la empresa privada y la iniciativa empresarial son las llaves de la innovación y de la creación de la riqueza; los derechos de propiedad intelectual son garantizados para estimular los cambios tecnológicos; se asegura la eliminación de la pobreza a través de los mercados libres y del libre comercio; se dice que la ausencia de protección a los derechos de propiedad constituye una barrera que impide el desarrollo económico y el bienestar humano; se busca prohibir los bienes comunes para que no sean sobreexplotados irresponsablemente por cualquiera; se mantiene que el Estado no debe controlar ni explotar ningún sector de la economía porque ello empobrece a las sociedades y limita la competencia económica; se afirma que la privatización, la desregulación y la competencia eliminan los trámites burocráticos, incrementan la eficiencia, la productividad y se evita la corrupción; se argumenta que se defiende la libertad personal que es la base del desarrollo personal y de la economía; se asume que la competencia internacional mejora la eficiencia, la competitividad, reduce los precios y controla las tendencias inflacionarias; se sostiene que los tratados y acuerdos comerciales como el TLCAN son cruciales para el avance del proyecto neoliberal global, y se prefiere una democracia de élites y de expertos a una democracia de mayorías o popular para no poner en riesgo las libertades y los derechos de las minorías.

Sin embargo, los teóricos del neoliberalismo no suelen exponer las contradicciones del modelo neoliberal globalizador. Entre éstas se deben destacar las siguientes:

1) La competencia económica acaba muchas veces en monopolios y oligopolios, pues las empresas más fuertes expulsan a las más débiles del mercado.

2) La teoría económica neoliberal es incapaz de explicar la existencia de los monopolios naturales, como los que existen en el ámbito energético, principalmente en la electricidad. 
Este libro forma parte del acervo de la Biblioteca Jurídica Virtual del Instituto de Investigaciones Jurídicas de la UNAM

3) El modelo neoliberal se desentiende de los fallos del mercado; es decir, de las externalidades (quién paga la contaminación o la afectación al medio ambiente o a la salud que propicia la actividad económica de las empresas).

4) El modelo neoliberal desconoce las condiciones asimétricas de los diversos agentes que actúan en el mercado nacional y mundial, dado que, por ejemplo, no todos poseen el mismo nivel de información o las mismas capacidades tecnológicas.

5) El modelo neoliberal no se hace cargo de la existencia de determinados derechos de propiedad que, como la propiedad intelectual, propician la búsqueda de rentas y no la competencia económica.

6) El modelo neoliberal omite describir que en muchas ocasiones el desarrollo científico y tecnológico están desconectados del mercado y las innovaciones que se producen suelen no tener demanda.

7) El modelo neoliberal no da cuenta de las consecuencias especulativas que propicia la gran acumulación del capital financiero.

8) El modelo neoliberal tampoco atiende los elementos disolventes del propio modelo; es decir, quién se hace cargo de los menos aventajados de las sociedades y de los países.

9) El modelo neoliberal elude los elementos autoritarios que prohija, tales como la democracia electoral elitista o de expertos que promueve, lo que motiva amplios descontentos sociales por la ausencia de canales de participación efectivos.

10) El modelo neoliberal no afronta la ilegitimidad y opacidad que sostiene a los organismos financieros internacionales y a las corporaciones trasnacionales que crean y aplican el Soft Law y la lex mercatoria.

El Estado neoliberal globalizador mercantiliza todos los derechos humanos y los bienes comunes en beneficio de las grandes corporaciones trasnacionales; se mantiene autoritariamente con enormes déficits de legitimidad democrática y de transparencia, en tanto que no se promueve la participación y la deliberación pública de los asuntos colectivos. El Estado neoliberal globalizador no respeta el medio ambiente ni las culturas ancestrales, pues expolia y saquea intensiva y extensivamente los recursos naturales del planeta en beneficio de unos cuantos; además, es el principal promotor de la pobreza y la desigualdad mundial. Es un Estado diseñado desde los intereses de las clases dominantes y, por tanto, alienta Estados racistas, clasistas y profundamente injustos que favorecen la represión policial de los débiles, la construcción de relaciones interpersonales basadas en el miedo, en el estereotipo, en la distancia física y en la sospecha. 
Este libro forma parte del acervo de la Biblioteca Jurídica Virtual del Instituto de Investigaciones Jurídicas de la UNAM

La finalidad de este trabajo fue presentar, como ya lo hemos dicho, en clave jurídica los efectos sociales y económicos de cada forma de Estado, sobre todo del Estado neoliberal. La pretensión es que el Estado sí sea agente de garantía de los derechos humanos y de los principios democráticos; pero, para ello, es indispensable la modificación sustancial de los modos de producción capitalistas actuales y su sustitución por otros que permitan la construcción de sociedades más libres e igualitarias ante nuevos retos mundiales nunca antes conocidos como el cambio climático, las migraciones masivas y los nuevos desarrollos científicos y tecnológicos. El cambio del modelo económico neoliberal que produce profundas desigualdades sólo depende de nosotros y de nuestras luchas. 
Este libro forma parte del acervo de la Biblioteca Jurídica Virtual del Instituto de Investigaciones Jurídicas de la UNAM

\section{BIBLIOGRAFÍA}

Abendroth, Wolfgang et al., El Estado social, Madrid, Centro de Estudios Políticos y Constitucionales, 1986.

ABENDROTH, Wolfgang y LENK, Kurt, Introducción a la ciencia política, Barcelona, Anagrama, 1971.

Abramovich, Víctor y COURTIS, Christian, Los derechos sociales como derechos exigibles, Madrid, Trotta, 2002.

ÁGuila, Rafael del, La senda del mal, política y razón de Estado, Madrid, Taurus, 2000.

- Manual de ciencia política, Madrid, Trotta, 1997.

Alba Vega, Carlos et al., La globalización desde abajo. La otra economía mundial, México, Fondo de Cultura Económica-El Colegio de México, 2015.

ALEXY, Robert, "Epílogo a la teoría de los derechos fundamentales", Revista Española de Derecho Constitucional, Madrid, núm. 66, septiembre de 2002.

—_, "Ponderación, control de constitucionalidad y representación", Cáatedra Ernesto Garzón Valdés 2004, México, Fontamara, 2005.

—_ "Sistema jurídico, principios jurídicos y razón práctica", Revista Doxa, Alicante, núm. 5, 1988.

-, Teoría de la argumentación jurídica, Madrid, Centro de Estudios Políticos y Constitucionales, 1989.

—, Teoría de los derechos fundamentales, Madrid, Centro de Estudios Políticos y Constitucionales, 1993.

— y ANDRÉS IBAÑEZ, Perfecto, Fueces y ponderación argumentativa, México, UNAM, 2006.

Alvarado, Arturo (ed.), La reforma de la justicia en México, México, El Colegio de México, 2008.

Anderson, Perry, El Estado absolutista, Madrid, Siglo XXI, 1979.

-, Transiciones de la antigüedad al feudalismo, Madrid, Siglo XXI, 1980.

ANDRÉS IBÁÑEZ, Perfecto, "Democracia con jueces", Claves de razón práctica, núm. 128, diciembre 2002. 
Este libro forma parte del acervo de la Biblioteca Jurídica Virtual del Instituto de Investigaciones Jurídicas de la UNAM

AnsolabeHERE, Karina, La política desde la justicia. Cortes supremas, gobierno y democracia en Argentina y México, México, FLACSO-Fontamara, 2007.

ARAngO, Rodolfo (ed.), Filosofía de la democracia. Fundamentos conceptuales, Bogotá, Siglo del Hombre Editores-Universidad de los Andes-Ceso, 2007.

AvRITzER, Leonardo, "Modelos de deliberación democrática: un análisis del presupuesto participativo en Brasil", Democratizar la democracia. Los caminos de la democracia participativa, México, Fondo de Cultura Económica, 2004. vol. 4, núm. 14, abril-junio de 2000.

Bauman, Zygmunt, La globalización. Consecuencias humanas, México, Fondo de Cultura Económica, 2015.

Bentham, Jeremy, Escritos Económicos, México, Fondo de Cultura Económica, 1978.

—- Un fragmento sobre el gobierno, Madrid, Tecnos, 2010.

BEnZ, Arthur, El Estado moderno. Fundamentos de su análisis politológico, Madrid, Centro de Estudios Políticos y Constitucionales, 2010.

Berger, Claude, Marx frente a Lenin, Bilbao, Zero, 1977.

BERLIn, Isaiah, Karl Marx, Alianza, Madrid, 1973.

BEverIDGE, William, Full Employment in a Free Society, Londres, Allen and Unwin, 1944.

—- Seguridad social y servicios afines. Las bases de la seguridad social, México, Fondo de Cultura Económica, 1946.

BICKel, Alexander, The Least Dangerous Branch, New Haven, Yale University Press, 1962.

BLAIR, Tony, La tercera vía, Madrid, Santillana, 1998.

Blas Guerrero, Andrés de y García Cotarelo, Ramón, Teoría del Estado, Madrid, Universidad Nacional de Educación a Distancia, 1988.

BobBIo, Norberto, Diccionario de Política, México, Siglo XXI, t. II, 1988.

, El tiempo de los derechos, Madrid, Sistema, 1991.

- La teoría de las formas de gobierno en la historia del pensamiento político, México, Fondo de Cultura Económica, 2014.

-, Teoría general de la política, Madrid, Trotta, 2003.

, Teoría general del derecho, Madrid, Debate, 1992.

Bodino, Juan, Los seis libros de la República, Madrid, Aguilar, 1973.

BoHman, James, "La democracia deliberativa y sus críticos", Metapolítica, vol. 4, núm. 14, abril-junio de 2000. 
Este libro forma parte del acervo de la Biblioteca Jurídica Virtual del Instituto de Investigaciones Jurídicas de la UNAM

Cabo Martín, Carlos de, La crisis del Estado social, Barcelona, PPU, 1986.

GAPELLA, Juan Ramón, Las sombras del sistema constitucional español, Madrid, Trotta, 2003.

Carbonell, Miguel (coord.), Neoconstitucionalismo(s), Madrid, Trotta, 2003.

Carbonell, Miguel (comp.), Teoría de la Constitución. Ensayos escogidos, México, Porrúa-UNAM, 2002.

y García JARAMillo, Leonardo (coords.), El canon neoconstitucional, Madrid, Trotta, 2010.

y SALAZAR, Pedro, La reforma constitucional de derechos humanos. Un nuevo paradigma, México, Porrúa-UNAM, 2012.

CÁRDEnas Gracia, Jaime, "El modelo participativo y deliberativo", Cuestiones Constitucionales. Revista Mexicana de Derecho Constitucional, México, núm. 11, México, 2004.

, "La minería en México: despojo a la nación", Revista Cuestiones Constitucionales, México, núm. 28, enero-junio de 2013. 2014.

- Crítica a la reforma constitucional energética de 2013, México, UNAM, , El modelo jurídico del neoliberalismo, México, UNAM, 2015, (en prensa). , La argumentación como derecho, México, UNAM, 2005.

(coord.), Reforma energética: análisis y consecuencias, México, UNAM-Tirant Lo Blanch, 2015.

— La crisis del sistema electoral mexicano. A propósito del proceso electoral de 2012, México, UNAM, 2014.

-, Manual de argumentación jurídica, México, Porrúa, 2014.

-, Poderes fácticos e incompatibilidades parlamentarias, México, UNAM, 2006.

-, En defensa del petróleo, México, UNAM, 2009.

- y Mijangos Borja, María de la Luz, Estado de derecho y corrupción, México, Porrúa, 2005.

Cassirer, Ernst, El mito del Estado, México, Fondo de Cultura Económica, 1982.

Gastillo Velasco, José María del, Apuntamientos para el estudio del derecho constitucional mexicano, México, Miguel Ángel Porrúa, 2007.

Centro de Estudios Miguel ENRÍQUez, Estado policial. Una aproximación al concepto, Chile, Archivo Chile Taller Rodriguista, 2005.

Chamseddine, Roqayah, "La militarización de las agencias de policía. Desde Ferguson hasta el Medio Oriente", California, Estados Unidos de América, Colectivo todo poder al pueblo, 2014. 
Este libro forma parte del acervo de la Biblioteca Jurídica Virtual del Instituto de Investigaciones Jurídicas de la UNAM

CLÉRICO, Laura, El examen de proporcionalidad en derecho constitucional, Buenos Aires, Eudeba, 2009.

- et al. (coords.), Derechos fundamentales, principios y argumentación, Granada, Editorial Comares, 2011.

CoHen, Joshua, "Procedimiento y sustancia en la democracia deliberativa", Metapolítica, vol. 4, núm. 14, abril-junio de 2000.

Coll, Steve, Private Empire: Exxon Mobil and American Power, Londres-Nueva York, Penguin, 2013.

Corcuera Atienza, Javier y García Herrera, Miguel Ángel, Derecho y economía en el Estado social, Madrid, Tecnos, 1988.

Cordero, María Elena, Qué ganamos y qué perdimos con el TLC, México, Siglo XXI-UNAM, 2003.

CortinA, Adela, Ética aplicada y democracia radical, Madrid, Tecnos, 1993.

, "Ética del discurso y democracia participativa", Revista Sistema, núm. 112, enero de 1993.

Cosío Villegas, Daniel, La Constitución de 1857 y sus críticos, 2a. ed., México, Fondo de Cultura Económica y Clío, 2007.

CRICK, Bernard, Basic Forms of Government: a Sketch and a Model, Londres, Macmillan, 1973.

—, Socialismo, Madrid, Alianza, 1994.

Gronin, Thomas E., Direct Democracy: The Politics of Initiative, Referendum and Recall, Cambridge, Cambridge University Press, 1989.

Croosman, R. H. S., Biografia del Estado moderno, México, Breviarios del Fondo de Cultura Económica, 1974.

——, La poliarquía, participación y oposición, Madrid, Tecnos, 2009.

y Lindblom, Charles, Politics, Economy and Walfare. Planning and Politico-Economic Systems Resolved into Basic Social Processes, Nueva York, Harper, 1953.

DAHRENDORF, Ralph, Oportunidades vitales, Madrid, Espasa Calpe, 1982.

DERridA, Jacques, Canallas. Dos ensayos sobre la razón, Madrid, Trotta, 2005.

DiAmond, Larry, Developing, Democracy Toward Consolidation, Baltimore, Johns Hopkins University Press, 1999.

DíAz, Elías, Estado de derecho y sociedad democrática, Madrid, Edicusa, 1972.

- Legalidad-legitimidad en el socialismo democrático, Madrid, Civitas, 1978.

y Ruiz Miguel, Alfonso, Filosofía politica II. Teoría del Estado, Madrid, Trotta, 1996. 
Este libro forma parte del acervo de la Biblioteca Jurídica Virtual del Instituto de Investigaciones Jurídicas de la UNAM

DíAz Polanco, Héctor, Elogio de la diversidad: globalización, multiculturalismo y etnofagia, México, Siglo XXI, 2007.

DILLARD, Dudley, La teoría económica de Fohn Maynard Keynes. Teoría de una economía monetaria, Madrid, Editorial Aguilar, 1981.

Douzinas, Costas, El fin de los derechos humanos, Antioquia Colombia, Legis Editores, 2008.

DurkheIM, Emilio, Lecciones de sociología, Buenos Aires, Pléyade, 1974.

DWORKIn, Ronald, El imperio de la justicia, Barcelona, Gedisa, 1988.

— Los derechos en serio, Barcelona, Ariel, 1984.

ELSTER, Jon, La democracia deliberativa, Barcelona, Editorial Gedisa, 2001.

ELY, John, Democracy and Distrust. A Theory of Fudicial Review, Cambridge, Harvard University Press, 1980.

ENGELS, Friedrich, El origen de la familia, la propiedad y el Estado, Madrid, Fundamentos, 1970.

Engle, Merry Sally et al., Pluralismo jurídico, Bogotá, Siglo del Hombre Editores-Universidad de los Andes-Pontificia Universidad Javeriana, 2007.

EsPosito, Roberto, Diez pensamientos acerca de la política, México, Fondo de Cultura Económica, 2012.

Evans, Peter, Dependent Development: the Alliance of Multinational, State and Local Capital in Brazil, Princeton, Princeton University Press, 1979.

FARIA, José Eduardo, El derecho en la economía globalizada, Madrid, Trotta, 2001.

Ferguson, John M., Historia de la Economía, México, Fondo de Cultura Económica, 1974.

FERrajoli, Luigi, "Es posible una democracia sin Estado", Razones jurídicas del pacifismo, Madrid, Trotta, 2004.

, "La crisis de la democracia en la era de la globalización", Law and Justice in a global society, Granada, Anales de la Cátedra Francisco Suárez, 2005.

-, Democracia y garantismo, Madrid, Trotta, 2010.

-, Derecho y razón. Teoría del garantismo penal, Madrid, Trotta, 2009.

-, Derechos y garantías: La ley del más débil, Madrid, Trotta, 2010.

-, Poderes salvajes. La crisis de la democracia constitucional, trad. de Perfecto Andrés Ibáñez, Madrid, Trotta, 2011.

\section{2, 2011.}

, Principia iuris. Teoría del derecho y de la democracia, Madrid, Trotta, vol.

- Los fundamentos de los derechos fundamentales, Madrid, Trotta, 2001. 
Este libro forma parte del acervo de la Biblioteca Jurídica Virtual del Instituto de Investigaciones Jurídicas de la UNAM

Ferriz SÁnchez, Remedios y García Soriano, María Vicenta, Suiza. Sistema político y Constitución, Madrid, Centro de Estudios Políticos y Constitucionales, 2002.

FIORAVANTI, Maurizio, Constitucionalismo. Experiencias históricas y tendencias actuales, Madrid, Trotta, 2014.

FLINT, Colin, Introduction to Geopolitics, Nueva York, Routledge, 2012.

Friedman, Milton y Friedman, Rose, La tiranía del status quo, Barcelona, Ariel, 1984.

Galgano, Francesco, Las instituciones de la economía capitalista, Valencia, Fernando Torres, 1980.

GARCíA AMADO, Juan Antonio, “ ¿Existe discrecionalidad en la decisión judicial? O de cómo en la actual teoría del derecho (casi) nada es lo que parece y (casi) nadie está donde dice", Berbiquí, núm. 30, 2005.

GARCíA ANIZA, Fernanda, Los derechos económicos, sociales, culturales y ambientales (DESCA) como derechos exigibles en el nuevo constitucionalismo latinoamericano, México, Comisión Nacional de Derechos Humanos, 2015.

García Cotarelo, Ramón, Del Estado del bienestar al Estado del malestar, Madrid, Centro de Estudios Políticos y Constitucionales, 1986.

García Figueroa, Alfonso, Principios y positivismo jurídico, Madrid, Centro de Estudios Políticos y Constitucionales, 1998.

García Pelayo, Manuel, Derecho constitucional comparado, Madrid, Alianza Editorial, 1984.

- El Estado de partidos, Madrid, Alianza Editorial, 1996.

- Las transformaciones del Estado contemporáneo, Madrid, Alianza Editorial, 1987.

—, Los mitos políticos, Madrid, Alianza Editorial, 1981.

GARCía RAmíREZ, Sergio y MORALES SÁnchez, Julieta, La reforma constitucional sobre derechos humanos (2009-2011), México, Porrúa-UNAM, 2011.

GARCía SAYÁn, Diego, "Nueva senda para los derechos económicos, sociales, culturales y ambientales", Revista de la Comisión Internacional de Juristas, núm. 55, núm. especial, 1995.

Gargarella, Roberto (coord.), Teoría y crítica del derecho constitucional, Buenos Aires, Abeledo Perrot, t. II, 2008.

— - La justicia frente al gobierno. Sobre el carácter contramayoritario del Poder Judicial, Barcelona, Ariel, 1996.

—, La sala de máquinas de la Constitución. Dos siglos de constitucionalismo en América Latina (1810-2010), Madrid, Katz, 2014. 
Este libro forma parte del acervo de la Biblioteca Jurídica Virtual del Instituto de Investigaciones Jurídicas de la UNAM

Gaventa, John, Power and Powerlessness. Quiescence and Rebellion in an Appalachian Valley, Estados Unidos de América, University of Illinois Press, 1982.

Godelier, Maurice, Teoría marxista de las sociedades precapitalistas, Barcelona, Laia, 1977.

Gómez-JARA DíEz, Carlos (ed.), El derecho como sistema autopoiético de la sociedad global, Colombia, Universidad Externado de Colombia, 2005.

Gómez-Palacio, Ignacio, Derecho de los negocios internacionales. Arbitraje Internacional, TLCAN, América Latina, CIADI, México, Porrúa, 2006.

Gonnard, René, Historia de las doctrinas económicas, Madrid, Aguilar, 1961.

GonzÁlez Casanova, José Antonio, Teoría del Estado y derecho constitucional, Barcelona, Ediciones Vicens-Vives, 1989.

GonZÁlez MÁrQUez, Felipe, Socialismo en libertad, Madrid, Galba, 1978.

Gramsai, Antonio, La política y el Estado moderno, Barcelona, Península, 1971.

Greenstein, Fred I. y Polsby, Nelson W. (eds.), Handbook of Political Science, Massachusetts, Addison-Wesley Publishing Company, 1975, vol. 3.

GuAstini, Riccardo, Estudios de teoría constitucional, México, FontamaraUNAM, Instituto de Investigaciones Jurídicas, 2007.

Guerra, Alfonso y Tezanos, José Félix (eds.), Alternativas para el siglo XXI. I Encuentro Salamanca, Madrid, Editorial Sistema, 2003.

HÄBERLE, Peter, El Estado constitucional, México, UNAM, 2001.

Habermas, Jürgen, Facticidad y validez, Madrid, Trotta, 1998.

, La inclusión del otro, Barcelona, Paidós, 1999.

-, Problemas de legitimación en el capitalismo tardio, Buenos Aires, Amorrortu Editores, 1973.

, Strukturwandel der Öffentlichkeit, Neuwied, 1962.

HaGOPIAN, Frances, "Derechos, representación y la creciente calidad de la democracia en Brasil y Chile", Política y gobierno, México, vol. XII, núm. 1, primer semestre de 2005.

HALLOWAY, John, Cambiar el mundo sin tomar el poder. El significado de la revolución hoy, Caracas, Venezuela, Vadell Hermanos, 2005.

Hamilton, Alexander et al., El federalista, México, Fondo de Cultura Económica, 1987.

HARRIS, David, La justificación del Estado del bienestar, Madrid, Instituto de Estudios Fiscales, 1990.

HART, Herbert L. A., El concepto de derecho, México, Editora Nacional, 1980.

HARveY, David, Breve historia del neoliberalismo, Madrid, Akal, 2013. 
Este libro forma parte del acervo de la Biblioteca Jurídica Virtual del Instituto de Investigaciones Jurídicas de la UNAM

- El enigma del capital y la crisis del capitalismo,
- El nuevo imperialismo, Madrid, Akal, 2004.

, Espacios de esperanza, Madrid, Akal, 2012.

- Seventeen Contradictions and the End of Capitalism, Oxford-Nueva York, Oxford University Press, 2014.

Hauriou, Maurice, Principios de derecho público y constitucional, Granada, Comares, 2003.

HayeK, Friedrich A., The Road to Serfdom, Chicago, Chicago University, 1944.

HegeL, Guillermo Federico, Filosofía del derecho, México, 1986.

HelD, David et al., Global transformations. Politics, Economics and Culture, Stanford, California, Stanford University Press, 1999.

- Globalización-Antiglobalización. Sobre la reconstrucción del orden mundial, Barcelona, Paidós, 2003.

Heller, Hermann, Teoría del Estado, México, Fondo de Cultura Económica, 2014.

Hernández CERVANTES, Aleida, La producción juridica de la globalización económica, México, UNAM-Universidad Autónoma de San Luis Potosí-Centro de Estudios Jurídicos y Sociales Mispat, 2014.

HERnÁNDEZ, Armando, Los derechos económicos, sociales, culturales y ambientales en el nuevo modelo constitucional de derechos humanos en México, México, Comisión Nacional de Derechos Humanos, 2015.

HobBes, Thomas, Leviatán o la materia, forma y poder de una República eclesiástica y civil, México, Fondo de Cultura Económica, 2014.

Horowitz, Irving Louis, Los anarquistas, Madrid, Alianza, 1975.

Huerta G., Arturo, Hacia el colapso de la economía mexicana. Diagnóstico, pronóstico y alternativas, México, UNAM, 2009.

Hume, David, Tratado de la naturaleza humana, 4a. ed., Madrid, Tecnos, 2005.

IGLESIAS, Pablo (coord.), Ganar o morir. Lecciones politicas en juego de tronos, Madrid, Akal, 2014.

Jalife-RAHME, Alfredo, Muerte de PEMEXy suicidio de México, México, Grupo Editor Orfila Valentini, 2014.

JellineK, Georg, Teoría general del Estado, México, Fondo de Cultura Económica, 2012.

JimÉnez CAmPO, Derechos fundamentales. Concepto y garantías, Madrid, Trotta, 1999.

KANT, Immanuel, ¿Qué es la ilustración?, Madrid, Alianza Editorial, 2007. 
Este libro forma parte del acervo de la Biblioteca Jurídica Virtual del Instituto de Investigaciones Jurídicas de la UNAM

—_, La metafisica de las costumbres, Madrid, Tecnos, 1989.

—_, La paz perpetua, Madrid, Tecnos, 1985.

KAPLAN, Marcos, Estado y globalización, México, UNAM, Instituto de Investigaciones Jurídicas, primera reimpresión, 2008.

Kelsen, Hans, Problemas capitales de la teoría jurídica del Estado, México, Porrúa, 1987.

-, Teoría general del derecho y del Estado, México, UNAM, 2010.

Keynes, John Maynard, Teoría general de la ocupación, el interés y el dinero, México, Fondo de Cultura Económica, 1965.

KRAUSE, Martín y MOLTENI, Margarita (coords.), Democracia directa, Buenos Aires, Abeledo-Perrot, 1997.

KÜHNL, Reinhard, Liberalismo y fascismo: dos formas de dominio burgués, Barcelona, Fontanella, 1978.

LaClaU, Ernesto, Debates y combates. Por un nuevo horizonte de la política, Buenos Aires, Fondo de Cultura Económica de Argentina, 2011.

y Mouffe, Chantal, Hegemonía y estrategia socialista. Hacia una radicalización de la democracia, México, Fondo de Cultura Económica, 2011.

LAPORTA, Francisco, "Globalización e imperio de la ley. Un texto provisional para el debate con algunas dudas y perplejidades de un viejo westfaliano", Law and Fustice in a Global Society, Granada, 2005.

LASKI, Harold J., El liberalismo europeo, México, Fondo de Cultura Económica, 2012.

LIJPHART, Arend, "Comparative Politics and the Comparative Method", American Political Science Review, vol. 65, núm. 3, septiembre de 1971.

LOCKE, John, Segundo tratado sobre el gobierno civil: un ensayo acerca del verdadero origen, alcance y fin del gobierno civil, Madrid, Tecnos, 2006.

López Calera, Nicolás María, Yo, el Estado, Madrid, Trotta, 1992.

Luhmann, Niklas, Teoría política en el Estado de bienestar, Madrid, Alianza Editorial, 1993.

MacPherson, C. B., La democracia liberal y su época, Madrid, Alianza Editorial, 1981.

MALEM, Jorge (comp.), La función judicial. Ética y democracia, Barcelona, Gedisa, 2003.

MaQuiavelo, Nicolás, Discursos sobre la primera década de Tito Livio, Madrid, Alianza Editorial, 1987.

— El príncipe, Madrid, Alianza Editorial, 1988. 
Este libro forma parte del acervo de la Biblioteca Jurídica Virtual del Instituto de Investigaciones Jurídicas de la UNAM

Marx, Carlos, Crítica de la filosofía del Estado de Hegel, México, Grijalbo, 1968. -, El capital, México, Fondo de Cultura Económica, 1979, t. I.

MARTINelli, José María (comp.), La actualidad de Gramsci: poder, democracia y mundo moderno, México, Universidad Autónoma Metropolitana, 1995.

Matamoros Ponce, Fernando, Memoria y utopía en México. Imaginarios en la génesis del neozapatismo, Xalapa, México, Universidad Veracruzana-Benemérita Universidad Autónoma de Puebla, 2005.

Mijangos GonzÁlez, Javier, "La doctrina de la Drittwirkung der Grundrechte en la jurisprudencia de la Corte Interamericana de Derechos Humanos", Teoría y realidad constitucional, Madrid, núm. 20, 2007.

Miliband, Ralph, El Estado en la sociedad capitalista, México, Siglo XXI, 1973.

Montero, José Ramón y Miley, Thomas Jeffrey (eds.), Democracias: quiebras, transiciones y retos, Madrid, Centro de Estudios Políticos y Constitucionales, 2009, t. 4.

Montesquieu, Charles de Secondat, Del espiritu de las leyes, Madrid, Tecnos, 2007.

Molina PiñeIro, Luis et al., ¿Constitucionalizar democratiza!, México, PorrúaUNAM, 2011.

Morlino, Leonardo, "Calidad de la democracia. Notas para su discusión", Metapolítica, México, enero-febrero de 2005.

Musgrave, Richard A., El futuro de la política fiscal, Madrid, Instituto de Estudios Económicos, 1980.

NAVArro, Vicenc, Bienestar insuficiente, democracia incompleta. Sobre lo que no se habla en nuestro país, Barcelona, Anagrama, 2015.

NEGRI, Antonio, El poder constituyente. Ensayo sobre las alternativas de la modernidad, Madrid, Libertarias-Prodhufi, 1994.

—, La forma-Estado, Madrid, Akal, 2003.

Neumark, Fritz, Principios de la imposición, Madrid, Instituto de Estudios Fiscales, 1994.

NinO, Carlos Santiago, "Los fundamentos del control judicial de constitucionalidad", Cuadernos y debates, Madrid, núm. 29, 1991.

— - Fundamentos de derecho constitucional, análisis jurídico y politológico de la práctica constitucional, Buenos Aires, Astrea, 1992. 1997.

O’Connor, James, La crisis fiscal del Estado, Barcelona, Península, 1981. 
Este libro forma parte del acervo de la Biblioteca Jurídica Virtual del Instituto de Investigaciones Jurídicas de la UNAM

O’Donnell, Guillermo, "Delegative Democracy", fournal of Democracy, vol. 5, núm. 1, 1994.

OFFE, Glaus, Contradicciones en el Estado del bienestar, Madrid, Alianza Editorial, 1990.

Oropeza GarcíA, Arturo, El acuerdo de asociación transpacífico. ¿Bisagra o confrontación entre el Atlántico y el Pacífico?, México, UNAM, 2013.

Ovejero, Félix, "Democracia liberal y democracias republicanas", Claves de Razón Práctica, Madrid, núm. 111, abril de 2001.

Paoli Bolio, Francisco José, Teoría del Estado, México, Trillas, 2009.

PARAMio, Ludolfo, La socialdemocracia, Madrid, Catarata, 2009.

Pashukanis, Evgeny, Teoría general del derecho y el marxismo, México, Grijalbo, 1976.

PÉrez López, M. Francisco y Rodríguez ARAMAYO, Roberto, Teoría y práctica, Madrid, Tecnos, 1986.

PÉREZ RoYO, Javier, Introducción a la teoría del Estado, Barcelona, Blume, 1980.

PIJL, Kees van der et al. (eds.), Global Regulation. Managing Crises after de Imperial Turn, Nueva York, Palgrave Macmillan, 2004.

PiketTy, Thomas, Capital in the Twenty-First Century, Estados Unidos de América, Harvard University Press, 2014.

- La crisis del capital en el siglo XXI. Crónicas de los años en que el capitalismo se volvió loco, México, Siglo XXI Editores, 2015.

Pisarello, Gerardo, Procesos constituyentes. Caminos para la ruptura democrática, Madrid, Trotta, 2014.

PolanyI, Karl, The Great Transformation, Boston, Beacon Press, 1954.

POPPER, Karl, La sociedad abierta y sus enemigos, Barcelona, Paidós Ibérica, 2010.

Porras NADAles, Antonio, Representación y democracia avanzada, Madrid, Centro de Estudios Políticos y Constitucionales, 1994.

Poulantzas, Nico, Poder político y clases sociales en el Estado capitalista, México, Siglo XXI Editores, 2007.

Prevost, Gary et al. (eds.), US National Security Concerns in Latin America and the Caribbean, Nueva York, Palgrave MacMillan, 2014.

PRIETO SANCHÍs, Luis, El constitucionalismo de los derechos. Ensayos de filosofía jurídica, Madrid, Trotta, 2013.

- Justicia constitucionaly derechos fundamentales, Madrid, Trotta, 2003.

RAWLS, John, La justicia como equidad. Una reformulación, Barcelona, Paidós, 2002.

RAZ, Joseph, La autoridad del derecho, México, UNAM, 1982. 
Este libro forma parte del acervo de la Biblioteca Jurídica Virtual del Instituto de Investigaciones Jurídicas de la UNAM

Rivero, Oswaldo de, El mito del desarrollo y la crisis de la civilización, México, Fondo de Cultura Económica, 2014.

RobInson, William I., América Latina y el capitalismo global. Una perspectiva crítica de la globalización, México, Siglo XXI Editores, 2015.

RogofF, Kenneth, "The Inequality Wildcard", Project Syndicate, Praga, 4 de febrero de 2011.

Rousseau, Jean Jacques, Discurso sobre el origen de la desigualdad entre los hombres, Madrid, Editorial Delta, 2013.

Rustow, Danwart, A., The Politics of Compromise. A Study of Parties and Cabinet Government in Sweden, Princeton, Nueva Jersey, Princeton University Press, 1955.

Sabine, George H., Historia de la teoría política, México, Fondo de Cultura Económica, 1988.

SALAZAR UGARTE, Pedro, La democracia constitucional: una radiografía teórica, Madrid, Fondo de Cultura Económica de España, 2007.

Salinas de Gortari, Carlos, México. Un paso difícil a la modernidad, México, Plaza and Janés, 2013.

SÁnchez CuencA, Ignacio y LLedó, Pablo, Artículos federalistas y antifederalistas. El debate sobre la Constitución americana, Madrid, Alianza Editorial, 2002.

Shapiro, Ian y Hacker-Cordón, Casiano, Democracy's Value, Cambridge University Press, Cambridge, 1999.

Sousa Santos, Boaventura de, Democratizar la democracia. Los caminos de la democracia participativa, México, Fondo de Cultura Económica, 2004.

Jornada, México, 5 de enero de 2016.

, La globalización del derecho. Los nuevos caminos de la regulación y la emancipación, Bogotá, Facultad de Derecho de la Universidad de Colombia-ILSA, 2002.

, Refundación del Estado en América Latina. Perspectivas desde una epistemología del Sur, México, Guatemala y Buenos Aires, Universidad de los AndesSiglo del Hombre Editores-Siglo XXI Editores, 2010.

— Sociología jurídica crítica. Para un nuevo sentido común en el derecho, Madrid, Trotta, 2009.

y RODRÍGUEz GARAVITO, César A., El derecho y la globalización desde abajo. Hacia una legalidad cosmopolita, Barcelona-México, Universidad Autónoma Metropolitana-Anthropos Editorial, 2007.

SCHMiTT, Carl, El nomos de la tierra en el derecho de gentes del 'Jus publicum europaeum", Madrid, Centro de Estudios Políticos y Constitucionales, 1979. 
Este libro forma parte del acervo de la Biblioteca Jurídica Virtual del Instituto de Investigaciones Jurídicas de la UNAM

dios Políticos y Constitucionales, 2011.

-, Sobre el parlamentarismo, Madrid, Tecnos, 1990.

SchumPeter, Joseph, Capitalism, Socialism and Democracy, Nueva York, Harper, 1962.

SERNA DE LA GARZA, José María, Globalización y gobernanza: Las transformaciones del Estado y sus implicaciones para el derecho público. (Contribución para una interpretación del caso de la Guardería ABC), México, UNAM, 2010.

Sieckman, Jan-R. (ed.), La teoría principalista de los derechos fundamentales. Estudios sobre la teoría de los derechos fundamentales de Robert Alexy, Madrid, Marcial Pons, 2011.

Slaugther, Ann Marie, A New World Order, Princeton, Princeton University Press, 2004.

SMITH, Adam, Investigación sobre la naturaleza y causas de la riqueza de las naciones, México, Fondo de Gultura Económica, 1958.

Sotelo, Ignacio, "El futuro del Estado social", Claves de razón práctica, Madrid, núm. 201, abril de 2010.

—, Filosofia política II. Teoría del Estado, Madrid, Trotta, 1996.

- El Estado social. Antecedentes, origen, desarrollo y declive, Madrid, Trotta, 2010.

Steger, Manfred B. y Roy, Ravi K., Neoliberalismo. Una breve introducción, Alianza Editorial, Madrid, 2011.

Steven, Lukes, El poder: un enfoque radical, Madrid, Siglo XXI Editores de España, 2007.

STIGLiTZ, Joseph E., El malestar en la globalización, Madrid, Santillana, 2002.

—, Cómo hacer que funcione la globalización, Madrid, Santillana, 2006.

Strachey, J., El capitalismo contemporáneo, México, Fondo de Cultura Económica, 1974.

StUART Mill, John, Sobre la libertad, Madrid, Tecnos, 2008.

—, El utilitarismo, Madrid, Alianza Editorial, 1984.

- Principios de economía politica, México, Fondo de Cultura Económica, 1985.

STUCKA, Peteris, La función revolucionaria del derecho y del Estado, Barcelona, Ediciones 62, 1969.

Sweezy, Paul M., Teoría del desarrollo capitalista, México, Fondo de Cultura Económica, 1981. 
Este libro forma parte del acervo de la Biblioteca Jurídica Virtual del Instituto de Investigaciones Jurídicas de la UNAM

SiEGKMANN, Jan-R. (ed.), La teoría principalista de los derechos fundamentales. Estudios sobre la teoría de los derechos fundamentales de Robert Alexy, Madrid, Marcial Pons, 2011.

Tello, Carlos e IBARRA, Jorge, La revolución de los ricos, México, UNAM, 2012.

TOCQUEVILLE, Alexis, El antiguo régimen y la revolución, Madrid, Fondo de Cultura Económica de España, 1996.

Troper, Michel, Por una teoría jurídica del Estado, Madrid, Dykinson, 2001.

VAlLEspín, Fernando, Historia de la teoría política. Historia, progreso y emancipación, Madrid, Alianza Editorial, 2002, vol. 4.

VARGAS, Rosío, El papel de México en la integración y seguridad energética de Norteamérica, México, UNAM, 2014.

VAROUFAKIS, Yanis, El minotauro global. Estados Unidos, Europa y el futuro de la economía mundial, México, Paidós, 2015.

VÁzQUEZ, Rodolfo, Derechos humanos. Una lectura liberal igualitaria, México, UNAM-ITAM-Gentro de Estudios de Actualización en Derecho, 2015.

VILLORO, Luis, "Sobre derechos humanos y derechos de los pueblos", Revista Isonomía, México, núm. 3, octubre de 1995.

VIOLA, Francesco, La democracia deliberativa entre constitucionalismo y multiculturalismo, México, UNAM, 2006.

Waldron, Jeremy, The Dignity of Legislation, Cambridge University Press, 1999.

WALERSteIn, Immanuel et al., ¿Tiene futuro el capitalismo?, México, Siglo XXI Editores, 2015.

Weber, Max, Economía y sociedad, México, Fondo de Cultura Económica, 2014.

Williamson, John (ed.), What Washington Means by Policy Reform, Washington, Peterson Institute for International Economics, 1990.

WiTKER, Jorge (coord.), El tratado de libre comercio de América del Norte. Evaluación jurídica: diez años después, México, UNAM, 2005.

- El tratado de libre comercio de América del Norte. Análisis, diagnóstico y propuestas jurídicas, México, UNAM, 1993, t. I.

y Hernández, Laura, Régimen jurídico del comercio exterior de México, México, UNAM, 2008.

Zagrebelsky, Gustavo, El derecho dúctil. Ley, derechos, justicia, Madrid, Trotta, 1995.

ZizeK, Slavoj, Menos que nada. Hegel y la sombra del materialismo dialéctico, Madrid, Akal, 2015. 
Del Estado absoluto al Estado neoliberal, editado por el Instituto de Investigaciones Jurídicas de la UNAM, se terminó de imprimir el 21 de marzo de 2017 en los talleres de Gráfica Premier, S. A. de C. V., 5 de febrero 2309, colonia San Jerónimo Chicahualco, Metepec, 52170 Estado de México, tel. 01722199 1345. Se utilizó tipo Baskerville en 9, 10 y 11 puntos. En esta edición se empleó papel cultural de $70 \times 95 \mathrm{~cm}$. de 75 gramos para los interiores y cartulina couché de 250 gramos para los forros; consta de 500 ejemplares (impresión offset). 
odemos decir que el Estado moderno es la forma de dominación política del modo de producción capitalista, como ya señalara el marxismo y otras corrientes del pensamiento. Los teóricos debaten sobre las características definitorias de ese modo de dominación; el sine qua non del capitalismo. Para algunos de ellos, sus elementos cruciales son la mano de obra asalariada, o la producción para el intercambio de ganancias, o la lucha de clases entre empresarios y trabajadores, o el mercado libre. Para otros, lo definitorio del capitalismo - Piketty — es la búsqueda interminable, sin fin y persistente, de la acumulación del capital.

En el libro hacemos un recorrido por los fundamentos económicos, filosóficos y jurídicos del Estado moderno. Establecemos las principales periodizaciones históricas de su manifestación: el Estado absoluto, el Estado liberal de derecho, el Estado del bienestar, el Estado constitucional, y el vigente, que denominamos Estado neoliberal. En cada una de esas etapas, que corresponden a formas específicas del Estado, elaboramos el modelo jurídico que ha pertenecido a cada estructura de dominación.

En la etapa vigente del Estado, la neoliberal, que se ha definido por el papel que dentro de él juega la economía global capitalista, observamos la extrema debilidad de las garantías para la efectiva existencia de los derechos humanos de carácter económico y social; así como la pérdida de centralidad de los principios democráticos, que son matizados o sustituidos por consideraciones de control hegemónico de naturaleza geopolítica. En esta modalidad de Estado asistimos al abismo social que se produce al interior de cada uno de ellos, y también a nivel global, en donde el $1 \%$ de los más ricos tiene el $43 \%$ de la riqueza mundial, mientras que la casi totalidad de la humanidad tiene menos del $2 \%$ de ella.

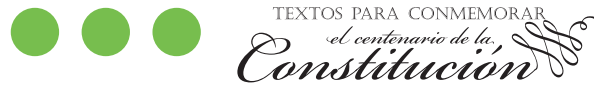

